\title{
Exploring broiler production systems that address multiple externalities
}

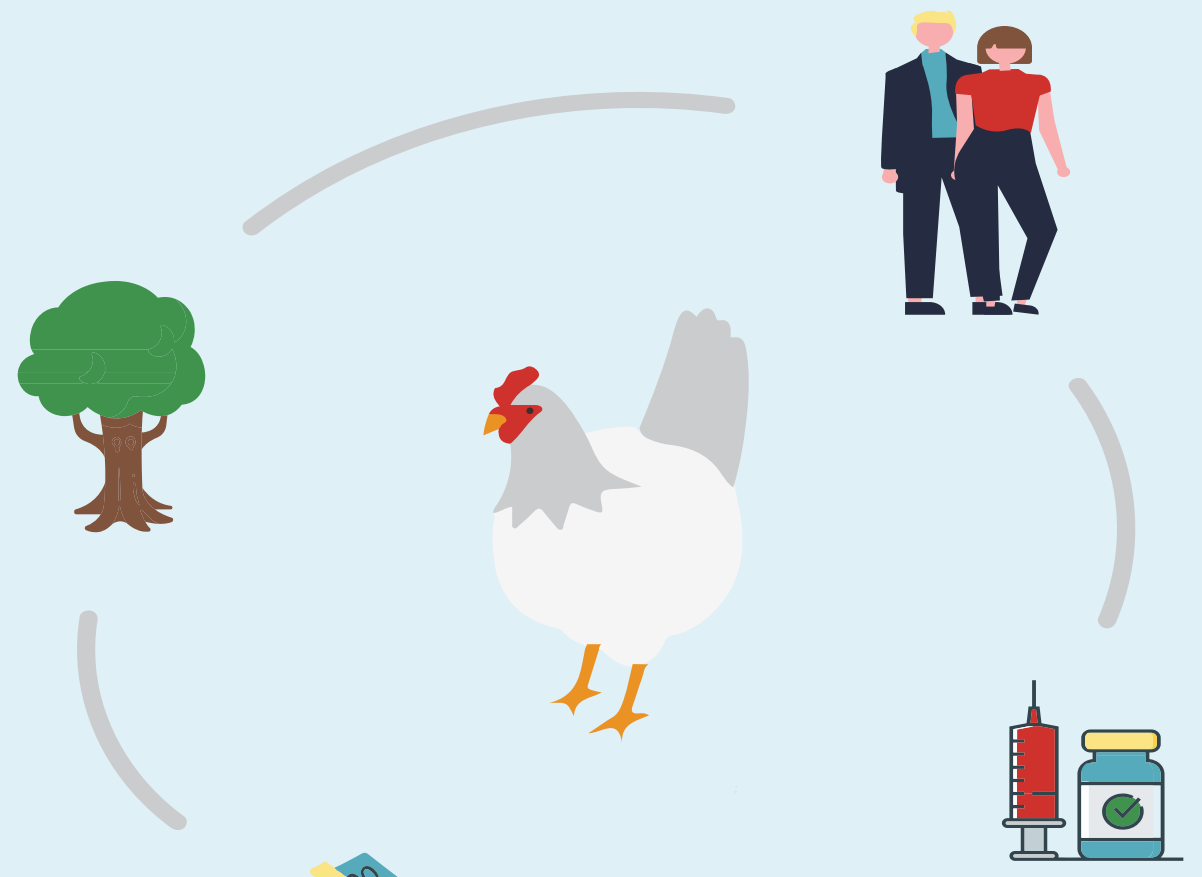

Luuk S.M. Vissers 


\section{Propositions}

1. Animal welfare improvements increase ammonia and particulate matter emissions per individual broiler produced, whereas at the farm level these emissions might be reduced.

(this thesis)

2. Financial compensation and certainty about future particulate matter legislation enhance broiler farmers' willingness to invest in particulate matter abatement techniques.

(this thesis)

3. Knowledge about ecological processes is essential for sustainable innovation.

4. Biodiversity-rich nature in the Netherlands requires policy intervention.

5. Consumers are responsible for sustaining negative externalities from intensive livestock production.

6. Universities can increase public support for scientific work by devoting more attention to informing the general public about solutions for societal challenges.

Propositions belonging to the thesis, entitled

Exploring broiler production systems that address multiple externalities

Luuk S.M. Vissers

Wageningen, 24 January 2022 


\section{Exploring broiler production systems that address multiple externalities}

Luuk S.M. Vissers 


\section{Thesis committee}

\section{Promotor}

Prof. Dr A.G.J.M. Oude Lansink

Professor of Business Economics

Wageningen University \& Research

\section{Co-promotor}

Dr H.W. Saatkamp

Associate professor, Business Economics Group

Wageningen University \& Research

\section{Other members}

Prof. Dr L.A. Den Hartog, Wageningen University \& Research

Prof. Dr E. Mathijs, KU Leuven, Belgium

Dr A. Kanellopoulos, Wageningen University \& Research

Dr L.H. Aramyan, Wageningen University \& Research

This research was conducted under the auspices of the Wageningen School of Social Sciences (WASS). 


\title{
Exploring broiler production systems that address multiple externalities
}

\author{
Luuk S.M. Vissers
}

\section{Thesis}

submitted in fulfilment of the requirements for the degree of doctor at Wageningen University

by the authority of Rector Magnificus,

$$
\text { Prof. Dr A.P.J. Mol, }
$$

in the presence of the

Thesis Committee appointed by the Academic Board

to be defended in public

on Monday 24 January 2022

at 4 p.m. in the Aula. 
Luuk S.M. Vissers

Exploring broiler production systems that address multiple externalities, 190 pages.

$\mathrm{PhD}$ thesis, Wageningen University, Wageningen, the Netherlands (2022)

With references, with summary in English

ISBN 978-94-6395-493-8

DOI https://doi.org/10.18174/554687 


\section{Abstract}

Intensive livestock production is associated with adverse effects on animal welfare (AW), the environment and human health, defined as negative externalities. These externalities have led to increasing calls for more sustainable livestock production, including more sustainable broiler production, by European Union citizens. The overall objective of this dissertation was to explore broiler production systems that address multiple externalities and are aligned with farmers' preferences. A conceptual framework was developed to assess the implementation of standards in a context of multiple negative externalities resulting from meat production. The framework demonstrated that synergies between externalities enhance the economic feasibility of more stringent standards, whereas trade-offs hamper the economic feasibility of these standards. AW improvements in broiler production may yield a synergy on antibiotic use and do not necessarily yield a trade-off on ammonia $\left(\mathrm{NH}_{3}\right)$ emissions. Most $\mathrm{AW}$ improvements caused a trade-off on particulate matter $\left(\mathrm{PM}_{10}\right)$ emissions. The findings suggest that there is a scope for designing optimal broiler production systems by selecting system changes based on their impact on farm income, $\mathrm{AW}, \mathrm{NH}_{3}$ and $\mathrm{PM}_{10}$ emissions. Different combinations of system changes were assessed in terms of their potential for enhancing AW and mitigating emissions of $\mathrm{NH}_{3}$ and $\mathrm{PM}_{10}$. The prevailing system in the Dutch broiler market was used as a baseline for evaluating these system changes. The results indicated that a considerable improvement in AW and considerable reductions in $\mathrm{NH}_{3}$ emissions (66-73\%) and $\mathrm{PM}_{10}$ emissions (41-61\%) can be achieved in this system at a limited increase in the producer price (5-19\%). The best performing combinations of system changes included AW-enhancing practices, a $\mathrm{NH}_{3}$ abatement technique and a $\mathrm{PM}_{10}$ abatement technique. These combinations were also robust to changes in the relative importance society places in $\mathrm{AW}, \mathrm{PM}_{10}$ emissions and $\mathrm{NH}_{3}$ emissions. Results of a discrete choice experiment indicated that farmers were in general reluctant to invest in $\mathrm{PM}_{10}$ abatement techniques. Farmers' preferences for $\mathrm{PM}_{10}$ abatement techniques were critically determined by the attributes technique, exemption from future $\mathrm{PM}_{10}$ emission legislation and subsidy. A high heterogeneity in farmers' preferences was observed, which could be explained by social factors (e.g. age of the farmer) and perceived obstacles for business development (e.g. location of the farm). Overall, this dissertation underlined that the development of new broiler production systems should focus on an integrated approach that takes the optimization of synergies trade-offs between externalities into account. 



\section{Contents}

Chapter 1 General introduction 9

Chapter 2 A multiple-standards framework to address externalities resulting from meat production

Chapter 3 Analysis of synergies and trade-offs between animal welfare, ammonia emission, particulate matter emission and antibiotic use in Dutch broiler production systems

Chapter 4 Exploring the performance of system changes in Dutch broiler production to balance animal welfare, ammonia emissions and particulate matter emissions with farm profitability

Chapter 5 Subsidy or more policy certainty: what makes broiler farmers more likely to invest in particulate matter abatement techniques? 111

Chapter 6 General discussion

Summary 176

Samenvatting 180

Acknowledgements 185

About the author 187

Training and supervision plan 188 


\section{Chapter 1}

General introduction 


\section{Chapter 1}

\subsection{Background}

After the Second World War, broiler production in North-West Europe changed drastically as a result of changes in European agricultural policy that focused on producing as much food as possible for a low price and a reasonable income for farmers (Winter et al., 1998). These policy changes stimulated European farmers to strive for production efficiency, resulting in an intensification and specialization of broiler farms, and an increase in the productivity of broilers (Meerburg et al., 2009). The intensification of broiler farms particularly took place in the Netherlands, as reflected by a decrease in the number of farms and an increase in the number of animals kept in the farm. In the period 1960-2020, the number of poultry farms in the Netherlands decreased from nearly 200 thousand to 2 thousand, while the number of broilers increased from 4.5 million to approximately 49 million. To increase production efficiency, farmers specialized and focused on one type of animal, i.e. livestock production system (Meerburg et al., 2009). Due to genetic selection, the productivity of broilers increased tremendously in the past fifty years. From 1957 to 2005, broilers' average daily growth has increased by over $400 \%$, concurrent with a reduction of $50 \%$ in the feed conversion rate (Zuidhof et al., 2014).

Although the intensification of broiler production increased food security, it also caused growing concerns and heated societal debates about the negative effect of intensive broiler production on animal welfare (AW), biodiversity, the environment and human health. These effects are defined as externalities ${ }^{1}$. As of the early ' $70 \mathrm{~s}$ of the previous century, societal concern about the welfare of farmed animals emerged in Europe (Miele et al., 2013). In a recent survey of Eurobarometer (2016), 82\% of the European citizens indicated that the welfare of farmed animals should be better protected. In the past two decades, European citizens also expressed widespread concerns about the loss of biodiversity, air quality and the environment (Eurobarometer, 2013, 2015, 2017, 2019b). Broiler production is a source of these concerns as it is responsible for $10 \%$ of total particulate matter emissions and $3 \%$ of total ammonia emissions originating from agriculture in the European Union (European Environment Agency, 2020b). In the Netherlands, the loss of biodiversity and growing environmental problems are even more prominent,

\footnotetext{
${ }^{1}$ An externality is the indirect effect (e.g. environmental pollution) of one individual's consumption activity or production activity (e.g. broiler production) on the well-being or economic activities of other individuals (Calhoun, 2002). These effects can be negative (negative externality) or positive (positive externality).
} 
due to the high population density, and traffic and industry combined with a very high livestock density (TNO, 2019). To counteract the societal critique on livestock production, the European Union passed legislation on AW, food safety and the environment in the early 2000s (European Council Directive, 1998, 2000, 2001). Despite this legislation, the public concern persisted in the past 15 years (Eurobarometer, 2005, 2016, 2019b). To address the concern related to AW, NGOs and broiler chain actors introduced more extensive production systems, such as Better Life in the Netherlands and Label Rouge in France. The requirements of these systems go beyond the minimum legal requirements on $\mathrm{AW}$ and are found to improve AW (Bracke et al., 2019). Therefore, these systems partly addressed the societal critique related to this externality. However, as the newly introduced systems focus on only a single issue of concern, i.e. AW, they do not mitigate the concern related to other externalities. In fact, more extensive broiler production systems have a higher potential to contribute to acidification and eutrophication (expressed per kg edible carcass weight produced) compared to intensive conventional systems (Leinonen et al., 2012). The foregoing suggests that switching from conventional to more extensive systems addresses AW issues but increases environmental issues.

In order to address the persistent societal critique, the European Union, national governments and chain actors agreed upon new goals. For instance, the European Commission (2020) introduced the Farm to Fork strategy in 2016, which set goals specific to the agri-food sector such as a reduction in the nutrient losses and the sales of antimicrobials for farmed animals by $50 \%$ in 2030 . To improve the air quality, the Dutch government aims to reduce particulate matter emissions from poultry houses by 50\% in the period 2020-2030 (Dutch Ministry of Infrastructure and Water Management, 2019). A potential pathway towards achieving these goals is the development of sustainable broiler production systems. Lebacq et al. (2013) define a sustainable livestock production system as a system that is "economically viable for farmers, environmentally friendly, and socially acceptable". Various system changes can be applied to improve the sustainability of broiler production systems, such as sustainable farming practices or adaptations in the housing design (Bessei, 2006; Melse, 2009; Wood \& Van Heyst, 2016). These system changes may yield synergies or trade-offs between externalities. A synergy is defined as the mitigation of multiple negative externalities, whereas a trade-off is defined as the mitigation of one negative externality and the elevation of another. For example, the shift from a fast-growing breed towards a slower-growing breed causes synergy 


\section{Chapter 1}

by improving AW and animal health (Dixon, 2020). On the other hand, this change causes a trade-off as the increase in AW and animal health is associated with higher greenhouse gas emissions expressed in $\mathrm{CO}_{2}$ equivalent per bird (Tallentire et al., 2018). While improved animal health may lead to reduced health care costs and therefore enhanced profits, higher greenhouse gas emission may (partly) offset the added value for consumers. Hence, synergies and trade-offs between externalities may affect farm income and/or consumer willingness-to-pay. Therefore, this interaction effect may influence the economic feasibility of sustainable broiler production systems.

\subsection{Problem statement}

The example above illustrates that externalities are interrelated. Therefore, the development of new broiler production systems requires an integrated approach that analyzes systems in terms of their economic, ecological, and social performance (Bokkers \& De Boer, 2009). Castellini et al. (2012) and Rocchi et al. (2019) developed such an approach to assess the sustainability of different poultry production systems. To make a general sustainability evaluation, the authors selected environmental, social, meat quality and economic indicators. A shortcoming of these studies is that they only consider the sustainability of broiler production systems as a whole, thus ignoring the contribution of individual system changes to mitigating externalities. Extensive research has been carried out on the contribution of individual system changes to externalities in broiler production (Bessei, 2006; Leinonen et al., 2013; Leinonen et al., 2014; De Jong \& Gunnink, 2019). For instance, Dixon (2020) compared the welfare of fast-growing and slower-growing broiler strains, while Tallentire et al. (2018) analyzed the environmental impact of these broiler strains. However, this knowledge is scattered across research domains and has not been assessed together. Therefore, insight in the contribution of individual system changes to multiple externalities, and the synergies and trade-offs between these externalities, is currently lacking. As Dutch broiler farmers operate on a tight profit margin (Van Horne, 2020a), small changes in the production system can have a large impact on farm income. Exploiting synergies and minimizing trade-offs is therefore important for the development of broiler production systems that address multiple externalities.

To successfully address the societal concerns related to broiler production, newly designed broiler production system that address externalities should ultimately be acceptable for farmers. In the current economic and political environment, societal concerns about farm AW are addressed through beyond-legal requirements 
(Vanhonacker \& Verbeke, 2014), whereas environmental and human health related concerns are addressed through legal requirements (Dutch Ministry of Infrastructure and Water Management, 2017; Ministry of Agriculture, 2019). Therefore, new broiler production systems that address not only AW concerns but also environmental and human health concerns will most likely be implemented in a 'beyond legal' setting. In this setting, the adoption of a new broiler system is a voluntary choice of the farmer, i.e. it goes beyond legal minimum demands. Therefore, farmers' preferences for new broiler production systems and the factors that determine adoption of these systems should also be considered in system development. Gocsik et al. (2016b) and Gocsik et al. (2015) analyzed individual aspects of this problem. Gocsik et al. (2016b) analyzed broiler farmers' preferences for more AW-friendly production systems. A shortcoming of this study is that the monetary consequences of these systems are ignored. Gocsik et al. (2015) investigated broiler farmers' willingness-to-convert to more AW-friendly production systems. While these authors consider the monetary consequences of these systems, they consider only more AW-friendly systems thus ignoring systems addressing environmental externalities. In the light of the foregoing, insight is currently lacking in the potential to develop broiler production systems that mitigate multiple externalities and are aligned with farmers' preferences.

\subsection{Objective}

The overall objective of this dissertation was to explore broiler production systems that address multiple externalities and are aligned with farmers' preferences. The insights obtained from this dissertation can support decision making in the development of sustainable broiler production systems.

To achieve the overall objective, the following four sub-objectives were defined:

1. To develop a conceptual framework for analyzing the implementation of multiple standards that aim to address negative externalities of meat production;

2. To analyze synergies and trade-offs between externalities originating from broiler production systems;

3. To explore the performance of system changes that reduce externalities in broiler production;

4. To measure broiler farmers' preferences for investments in different particulate matter abatement techniques; 


\section{Chapter 1}

\subsection{Outline}

The dissertation is divided into six chapters, i.e. a general introduction (chapter 1), four research chapters (2-5) that elaborate on the beforementioned sub-objectives and the general discussion (chapter 6). Figure 1.1 provides a schematic outline of the dissertation.

Chapter 2 presents a multiple-standards framework to assess the economic feasibility of standards addressing negative externalities resulting from meat production. The framework was applied to the case of the new Dutch retail standard, which includes the introduction of a more stringent standard on AW in the Dutch broiler market.

Chapter 3 presents an approach to analyze the synergies and trade-offs between externalities originating from broiler production systems. The approach was applied to three existing Dutch broiler production systems, i.e. the conventional, new Dutch retail standard and extensive indoor+ system.

Chapter 4 explores the performance of system changes that mitigate externalities originating from broiler production. A benefit-of-the-doubt approach was used to aggregate the externalities into a composite indicator.

Chapter 5 measures broiler farmers' preferences for investments in different particulate matter abatement techniques and explores the relations with socio-economic demographics and perceived obstacles for business development. A discrete choice experiment was conducted for this purpose.

Chapter 6 contains the general discussion of the thesis. This chapter discusses the approaches and findings described in chapter 2 through 5, and elaborates on the implications of the results for business stakeholders and policy makers. This chapter ends with the main conclusions of the dissertation. 
General introduction

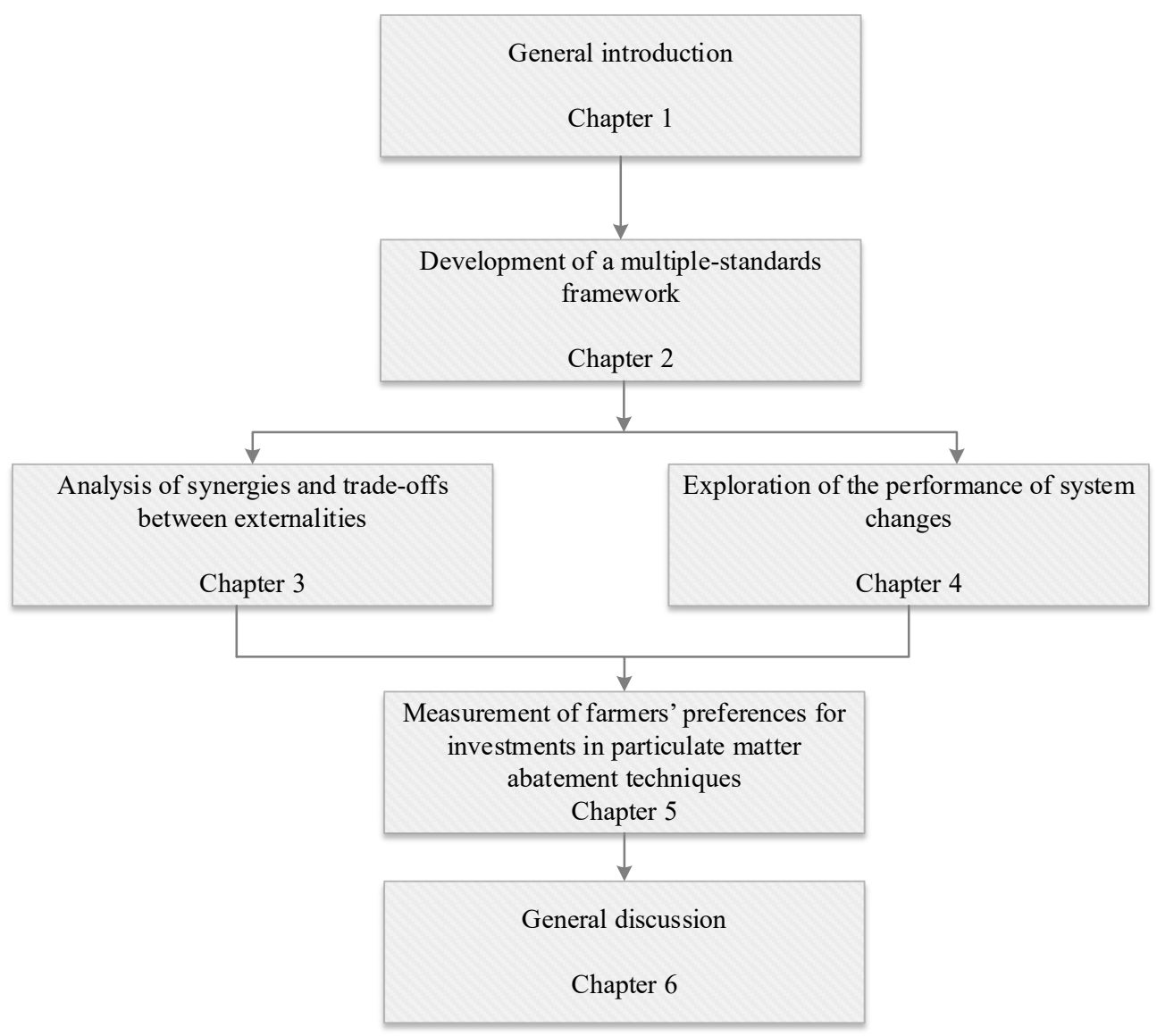

Figure 1.1 Schematic outline of the dissertation 


\section{Chapter 1}

\section{References}

Bessei, W. (2006). Welfare of broilers: a review. World's Poultry Science Journal, 62(3), 455-466. doi:https://doi.org/10.1017/S0043933906001085

Bokkers, E. A. M., \& De Boer, I. J. M. (2009). Economic, ecological, and social performance of conventional and organic broiler production in the Netherlands. British Poultry Science, 50(5), 546-557. doi:https://doi.org/10.1080/00071660903140999

Bracke, M. B. M., Koene, P., Estevéz, I., Butterworth, A., \& de Jong, I. C. (2019). Broiler welfare trade-off: A semi-quantitative welfare assessment for optimised welfare improvement based on an expert survey. PLoS One, 14(10), e0222955. doi:https://doi.org/10.1371/journal.pone.0222955

Calhoun, C. J., \& Oxford University, P. (2002). Dictionary of the social sciences. In. Retrieved from https://www-oxfordreferencecom.ezproxy.library.wur.nl/view/10.1093/acref/9780195123715.001.0001/ acref-9780195123715

Castellini, C., Boggia, A., Cortina, C., Dal Bosco, A., Paolotti, L., Novelli, E., \& Mugnai, C. (2012). A multicriteria approach for measuring the sustainability of different poultry production systems. Journal of Cleaner Production, 37, 192-201. doi:https://doi.org/10.1016/i.jclepro.2012.07.006

De Jong, I. C., \& Gunnink, H. (2019). Effects of a commercial broiler enrichment programme with or without natural light on behaviour and other welfare indicators. animal, 13(2), 384-391. doi:10.1017/S1751731118001805

Dixon, L. M. (2020). Slow and steady wins the race: The behaviour and welfare of commercial faster growing broiler breeds compared to a commercial slower growing breed. PLoS One, 15(4), e0231006. doi:https://doi.org/10.1371/journal.pone.0231006

Dutch Ministry of Infrastructure and Water Management. Besluit emissiearme huisvesting, W14.15.0152 C.F.R. (2017).

Dutch Ministry of Infrastructure and Water Management. (2019). Clean air agreement. Rijksoverheid Retrieved from https://www.rijksoverheid.nl/documenten/convenanten/2020/01/13/bijlage1-schone-lucht-akkoord.

Eurobarometer. (2005). Attitudes of consumers towards the welfare of farmed animals. Special Eurobarometer, 229, 45-46.

Eurobarometer. (2013). Attitudes of Europeans towards air quality. Retrieved from https://ec.europa.eu/commfrontoffice/publicopinion/flash/fl 360 en.pdf

Eurobarometer. (2015). Attitudes of Europeans towards biodiversity. Retrieved from https://op.europa.eu/nl/publication-detail/-/publication/50bfl efd720b-11e9-9f05-01aa75ed71a1/language-en/format-PDF

Eurobarometer. (2016). Attitudes of Europeans towards animal welfare. Retrieved from https://ec.europa.eu/commfrontoffice/publicopinion/index.cfm/ResultDoc/ download/DocumentKy/71348 
Eurobarometer. (2017). Attitudes of European citizens towards the environment. Retrieved from https://ec.europa.eu/public_opinion/archives/ebs/ebs 416 en.pdf.

Eurobarometer. (2019). Food Safety in the EU. European Commission Retrieved from

https://www.efsa.europa.eu/sites/default/files/corporate publications/files/ Eurobarometer2019 Food-safety-in-the-EU Full-report.pdf.

European Commission. (2020). Farm to Fork Strategy. Retrieved from https://ec.europa.eu/food/sites/food/files/safety/docs/f2f_actionplan_2020_strategy-info_en.pdf

European Council Directive. Directive 98/58/EC of 20 July 1998 concerning the protection of animals kept for farming purposes, 98/58/EC C.F.R. (1998).

European Council Directive. (2000). The Welfare of Chickens Kept for Meat production (broilers). Retrieved from https://ec.europa.eu/food/sites/food/files/safety/docs/scicom scah out39 en.pdf

European Council Directive. Directive 2001/81/EC of the European Parliament and of the council of 23 October 2001 on national emission ceilings or certain atmospheric pollutants, (2001).

European Environment Agency. (2020). National emissions reported to the Convention on Long-range Transboundary Air Pollution (LRTAP Convention). Retrieved from: https://www.eea.europa.eu/data-andmaps/data/national-emissions-reported-to-the-convention-on-long-rangetransboundary-air-pollution-lrtap-convention-14

Gocsik, É., Van der Lans, I. A., Oude Lansink, A. G. J. M., \& Saatkamp, H. W. (2015). Willingness of Dutch broiler and pig farmers to convert to production systems with improved welfare. Animal Welfare, 24(2), 211222. doi:https://doi.org/10.7120/09627286.24.2.211

Gocsik, É., Van der Lans, I. A., Oude Lansink, A. G. J. M., \& Saatkamp, H. W. (2016). Elicitation of preferences of Dutch broiler and pig farmers to support decision making on animal welfare. NJAS - Wageningen Journal of Life Sciences, 76, 75-86. doi:https://doi.org/10.1016/j.njas.2015.11.006

Lebacq, T., Baret, P. V., \& Stilmant, D. (2013). Sustainability indicators for livestock farming. A review. Agronomy for Sustainable Development, 33(2), 311-327. doi:https://doi.org/10.1007/s13593-012-0121-x

Leinonen, I., Williams, A. G., \& Kyriazakis, I. (2014). The effects of welfareenhancing system changes on the environmental impacts of broiler and egg production. Poultry Science, 93(2), 256-266. doi:https://doi.org/10.3382/ps.2013-03252

Leinonen, I., Williams, A. G., Waller, A. H., \& Kyriazakis, I. (2013). Comparing the environmental impacts of alternative protein crops in poultry diets: The consequences of uncertainty. Agricultural Systems, 121, 33-42. doi:10.1016/j.agsy.2013.06.008 
Chapter 1

Leinonen, I., Williams, A. G., Wiseman, J., Guy, J., \& Kyriazakis, I. (2012). Predicting the environmental impacts of chicken systems in the United Kingdom through a life cycle assessment: Broiler production systems. Poultry Science, 91(1), 8-25. doi:https://doi.org/10.3382/ps.2011-01634

Meerburg, B., Korevaar, H., Haubenhofer, D., Blom-Zandstra, M., \& Van Keulen, H. (2009). The changing role of agriculture in Dutch society. The Journal of Agricultural Science, 147(5), 511. doi:https://doi.org/10.1017/S0021859609990049

Melse, R. W. (2009). Air treatment techniques for abatement of emissions from intensive livestock production. Retrieved from http://edepot.wur.nl/12452 WorldCat.org database.

Miele, M., Blokhuis, H. J., Bennett, R., \& Bock, B. (2013). Changes in farming and in stakeholder concern for animal welfare. In Improving farm animal welfare (pp. 19-47): Springer.

Ministry of Agriculture, N. a. F. Q. Regeling Diergeneesmiddelen, (2019).

Rocchi, L., Paolotti, L., Rosati, A., Boggia, A., \& Castellini, C. (2019). Assessing the sustainability of different poultry production systems: A multicriteria approach. Journal of Cleaner Production, 211, 103-114. doi:https://doiorg.ezproxy.library.wur.n1/10.1016/j.jclepro.2018.11.013

Tallentire, C. W., Leinonen, I., \& Kyriazakis, I. (2018). Artificial selection for improved energy efficiency is reaching its limits in broiler chickens.

Scientific Reports, 8(1), 1168. doi:10.1038/s41598-018-19231-2

TNO. (2019). Factsheet emissies en depositie van stikstof in Nederland. Retrieved from The Hague:

https:/publications.tno.nl/publication/34634850/8Pywsn/TNO-2019emissies.pdf

Van Horne, P. L. M. (2020). Economics of broiler production systems in the Netherlands: economic aspects within the Greenwell sustainability assessment model. Retrieved from Wageningen: https://edepot.wur.nl/518522

Vanhonacker, F., \& Verbeke, W. (2014). Public and Consumer Policies for Higher Welfare Food Products: Challenges and Opportunities. Journal of Agricultural and Environmental Ethics, 27(1), 153-171. doi:10.1007/s10806-013-9479-2

Winter, M., Fry, C., \& Carruthers, S. P. (1998). European agricultural policy and farm animal welfare. Food Policy, 23(3), 305-323. doi:https://doi.org/10.1016/S0306-9192(98)00036-0

Wood, D. J., \& Van Heyst, B. J. (2016). A review of ammonia and particulate matter control strategies for poultry housing. Transactions of the ASABE, 59(1), 329-344. doi:https://doi.org/10.13031/trans.59.10836

Zuidhof, M. J., Schneider, B. L., Carney, V. L., Korver, D. R., \& Robinson, F. E. (2014). Growth, efficiency, and yield of commercial broilers from 1957, 1978, and 2005. Poultry Science, 93(12), 2970-2982. doi:https://doi.org/10.3382/ps.2014-04291 


\section{Chapter 2}

\section{A multiple-standards framework to address externalities resulting from meat production}

Luuk S.M. Vissers, Roel A. Jongeneel, Helmut W. Saatkamp, Alfons G.J.M Oude Lansink

Published in Applied Economic Perspectives and Policy. February 2021. DOI: https://doi.org/10.1002/aepp.13152 


\title{
Chapter 2
}

\begin{abstract}
This paper developed a framework for assessing the implementation of standards in a context of multiple negative externalities resulting from meat production. The framework was applied to the introduction of the New Dutch Retail Standard in the Dutch broiler market, a standard on animal welfare initiated by the private sector with national coverage. The results show that this standard did not lower producer, retailer, and consumer welfare; rather, social welfare increased by approximately 300 million euros. The framework provides a sound scientific basis for an ex ante analysis on the market potential of multiple standards.
\end{abstract}

Keywords: Externalities; Market effects; Meat supply chain; Partial equilibrium model 


\subsection{Introduction}

Intensive broiler and pig production systems have been under increased public scrutiny in the Netherlands, because of their negative side effects - defined as negative externalities - on Animal Welfare (AW), the environment, and public health (Eurobarometer, 2016, 2017, 2019b). For instance, the NGO Wakker Dier introduced the term 'plofkip' ('exploding chicken') to decry the leg problems that fast-growing broilers may develop when reared in intensive production systems. Although the EU has passed legislation to improve food safety, environmental footprints and AW (European Council Directive, 2001, 2003, 2008b), societal criticism persists. This criticism implies that further improvements should be implemented, beyond the prevailing legal minimum, in order to attain public acceptance both in the short and long term. To address the critique on AW, more extensive pig and broiler production systems have been developed in the Netherlands that exceed the minimum legal AW requirements (Gocsik et al., 2016a). However, farmers are reluctant to implement these systems (Gocsik et al., 2015), as they entail a higher cost of production relative to intensive production systems, while at the same time the price premium is uncertain. Therefore, the Dutch meat market faces a multiple externality problem: on the one hand society and specific consumer groups demand additional measures, and on the other hand financial insecurity withholds farmers from adopting such measures. Out of dissatisfaction with the current situation, some actors (partly) left the market. Certain consumers switched to a (semi-) vegetarian diet and some farmers adopted specific production systems with distribution channels to restaurants or online outlets (Reinders et al., 2013).

More stringent standards are required to address the externality problem but is it unclear how they should be introduced. Should these standards, for example, replace the minimum legal requirements and would government intervention be required? Standards are defined as requirements relating to inputs, production processes or final products that can solve market failure related to production or consumption externalities (Swinnen et al., 2015). As Dutch broiler and pig farmers operate in a market that is characterized by tight profit margins (Reinders et al., 2013), it is essential to understand the price incentive-compatibility of chain actors for a successful introduction of more stringent standards. However, a comprehensive theoretical economic understanding that supports value chain decision-making is still lacking. Earlier attempts to address this problem, such as the conceptual framework of Swinnen et al. (2015), analyze the welfare effects of 


\section{Chapter 2}

standards in value chains. Plastina and Giannakas (2007) developed a framework to analyze welfare effects under consumer aversion to genetically modified products. Neither framework elaborates on the price incentive-compatibility of chain actors, or takes into account multiple externalities or their potential interaction. Research has shown, however, that externalities related to on-farm animal management such as AW, animal health, and environmental impact, are interlinked. For example, a slower-growing breed results in improved AW and animal health (Gocsik et al., 2016a), but also has a larger carbon footprint compared to a fast-growing breed (Bokkers \& De Boer, 2009). While improved animal health may lead to reduced costs and therefore enhanced profits (Lusk \& Norwood, 2011), a higher carbon footprint may (partly) offset the added value for consumers.

The previous example illustrates that the interaction between externalities might affect production costs and consumer's Willingness-To-Pay (WTP). In the context of the externality problem, the existing frameworks cannot provide insight into the commercial feasibility of more stringent standards. This study contributes to the existing literature by developing an extended framework to analyze the implementation of multiple standards that aim to address negative externalities of meat production. This framework can be used to assess the socio-economic potential of new production systems, relying on private, public or public-private arrangements, as it allows for a quantitative analysis of the commercial feasibility of standards and the impact of government intervention on producer and consumer welfare. As such, the paper contributes to a more accurate assessment on the costs and prices of policies aimed at implementing production systems with more stringent standards.

The remainder of this paper is structured as follows. Section 2.2 develops the conceptual framework, which describes the economic effects of introducing a more stringent standard in a multiple standards-context followed by a theoretical underpinning of the framework. Section 2.3 applies the framework to the New Dutch Retail Standard, which includes the introduction of a more stringent standard on AW in the Dutch broiler market. Section 2.4 discusses the results and the policy implications and the paper ends with the conclusions.

\subsection{Conceptual framework}

\subsubsection{Description of standards in the meat supply chain}

The meat supply chain consists of input suppliers, farmers, processors, retailers and consumers. Farmers buy inputs from breeders and feed producers to produce 
livestock. As a joint product from this activity, (negative) externalities are generated. Animals are then slaughtered and processed, and consequently sold by the retailer to consumers. The externalities at farm level can be addressed by introducing a more stringent standard (Swinnen et al., 2015). The standard is assumed to be voluntary for farmers, i.e. the farmers can freely decide to adopt this standard or to adopt the less stringent, public mandatory standard. Furthermore, the standard is assumed to be exogenous, imposed only at farm level, and to affect only production-related traits (externalities). Hence, product-related traits (e.g. meat texture or taste) are unaffected. When imposing a more stringent standard at farm level, a negative externality would be reduced, but this standard would also involve higher production costs due to higher input prices and a decrease in the production efficiency (e.g. requiring higher input volumes). In order to guarantee the farmer's income, a higher producer price would be required. This means that, processors in turn would face higher resource costs and both a higher processor and consumer price are required to guarantee the profit of processors and retailers. A higher valuation of the product traits, via the reduction of the externalities, may offset the higher consumer price.

A successful introduction of a more stringent standard requires that each player in the chain is willing to adopt the standard. For simplicity, further analysis includes only the three main players in the chain: the producer, retailer and consumer. It is assumed that producers and retailers aim to maximize profits and consumers aim to maximize utility. Therefore, for a more stringent standard to be commercially feasible, it is assumed that the following three conditions have to be satisfied:

(i) producer's profits are not decreasing

(ii) retailer's profits are not decreasing

(iii) the increase in WTP equals or exceeds the increase in consumer price needed to cover all additional costs of the more stringent standard.

When introducing the more stringent standard, this standard may interact with another standard, thereby causing cost-savings and/or an additional increase in consumer's WTP, or adversely, an additional increase in production costs. In this paper, we defined a synergy as an interaction effect resulting in cost-savings or an additional increase in consumer's WTP, whereas we defined conflicting effects as an interaction effect leading to an additional increase in production costs or a mitigation of the increase in consumer's WTP. 


\section{Chapter 2}

\subsubsection{Economic effect of standards per actor}

To model the economic effect of a more stringent standard, the producer and retailer profit function from Swinnen et al. (2015) and the consumer utility function from Plastina and Giannakas (2007) were used as a starting point in the theoretical framework. In the framework we considered the economic effects only from a national perspective. Throughout it is assumed that producers are risk neutral and maximize short-run profits, with the latter implying that quasi-fixed inputs are unaffected by production and standards.

\section{Producer}

The producer's objective is to maximize profits, given the selected standard, by setting output. The producer's profit is calculated by subtracting variable costs and fixed costs from the revenues. A mathematical substantiation of the producer's profit relationship and the economic effect of a more stringent standard on producer profits is provided in Appendix 2A. It is assumed that the producer price is either unaffected by the standard or increased with the intensity of the standard. Per unit variable costs are assumed to be increasing and strictly convex in the intensity of the standard. An increase in a standard decreases production (ceteris paribus). When increasing the intensity of a standard, the interaction of the standard with a different standard, can have a positive, negative or no effect on variable costs. For independent standards, the interaction does not affect variable costs. In case of conflicting standards, the interaction causes an additional increase in variable costs, relative to separate standard implementation. In contrast, synergy between standards implies that the cost increase associated with an increase in a specific standard is partly offset by cost-savings from a different standard. For example, slower-growing breeds can be introduced to satisfy a relatively high AW standard. As slower-growing breeds are less susceptible to diseases than fastgrowing breeds they require less antibiotics (Van Geijlswijk et al., 2019), thereby resulting in cost-savings on animal health. Appendix 2A provides a mathematical substantiation of these interaction effects.

\section{Retailer}

Based on the selected standard, the retailer's objective is to maximize profits by choosing the optimal quantity of output. The retailer's profits are equal to revenues minus handling costs. The handling costs consist of activities such as wholesaling, labelling and marketing. A more stringent standard at farm level would result in an increase of the producer price, and therefore an increase in the retailer's marginal costs. To prevent a decrease in the retailer's profits, the consumer price needs to 
increase to cover the additional costs. A mathematical notation of the profit function and the economic effect of a more stringent standard on retailer profits is provided in Appendix 2A.

\section{Consumer}

When making purchase decisions, consumers make a trade-off between the product's traits and the consumer price (De Jonge \& Van Trijp, 2013). In this purchase decision, the following three products are considered: a meat product (e.g. broiler meat) containing a less stringent standard, the same meat product containing a more stringent standard and a substitute (e.g. pork). It is assumed that all products are labelled. A mathematical description of the effect of a more stringent standard on consumer utility is shown in Appendix 2A. It is assumed that a consumer experiences a base level of utility derived from the product related traits (such as texture and taste), which is unaffected by standards. Furthermore, a consumer experiences disutility from the consumer price and from the negative externalities of the meat product. It is assumed that the disutility from the consumer price and the negative externalities are both affected by the standard. Because of consumer heterogeneity, it is assumed that the disutility from the negative externalities differs among consumers. A consumer experiences two opposite effects when consuming a more stringent standard meat product relative to consuming a less stringent standard meat product, namely (1) a (possible) increase in utility from the decrease in the negative externalities and (2) a decrease in utility from the increase in consumer price.

The more stringent standard can be introduced in the market in two ways, namely as a voluntary standard or as a pseudo-mandatory standard. A pseudo-mandatory standard is defined as a standard initiated by the private sector with national coverage and operates as such in a similar way as a mandatory public standard. Hence, the less stringent standard meat product is no longer on offer in case of a pseudo-mandatory standard, while it still is in case of a voluntary standard. When introducing the more stringent standard as a voluntary standard, both meat products are on offer, and consumers may prefer one over the other. In Figure 2.1, these preferences are depicted for three consumer groups:

- Consumers for which the increase in utility from the standard (caused by decrease in the negative externalities) exceeds the decrease in utility from the increase in consumer price will prefer the more stringent standard meat product (consumers from group 1 in Figure 2.1). 


\section{Chapter 2}

- Consumers for which the decrease in utility from the increase in consumer price exceeds the increase in utility from the standard will prefer the less stringent standard meat product (consumers from group 2 and 3 ).

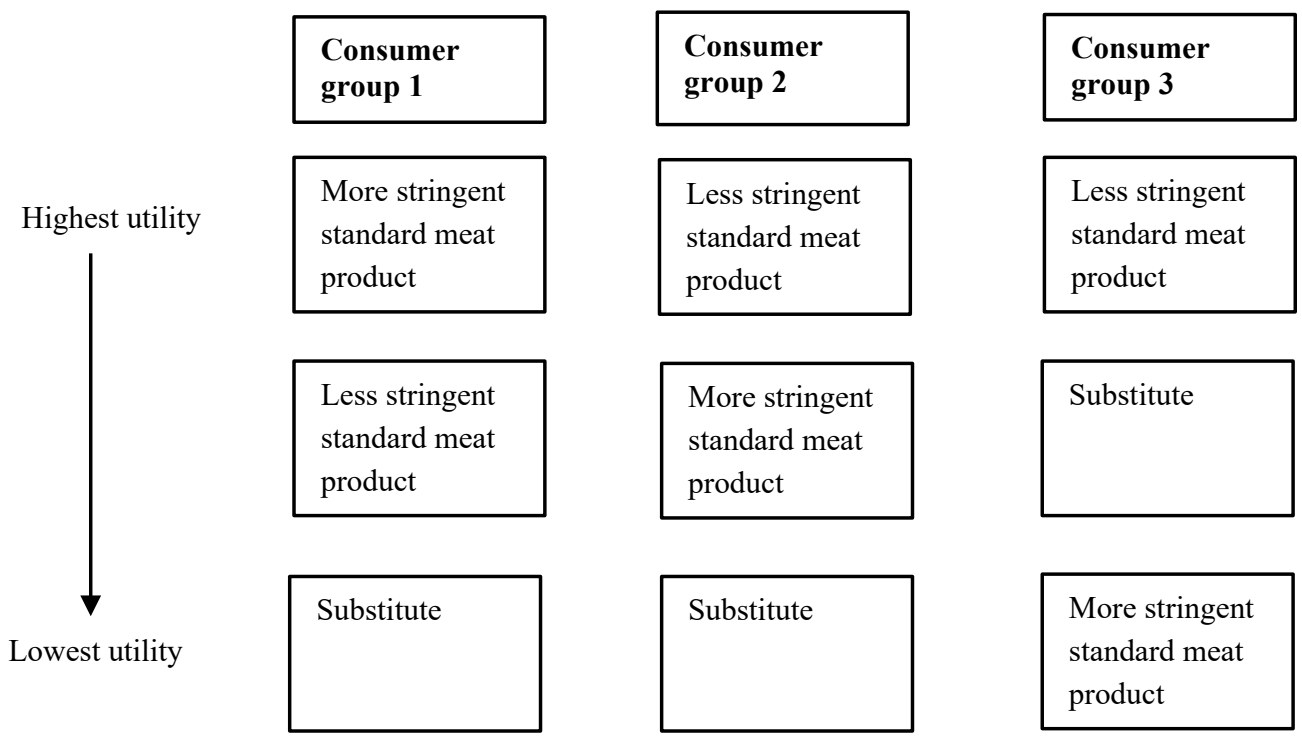

Figure 2.1 Ranking of consumer preferences for the meat products based on the utility derived from the products, differentiated for three types of consumer groups

Whereas consumers from group 1 are net beneficiaries from the increased standard, consumers from group 2 and 3 face a welfare loss from this standard. When introducing the more stringent standard as a pseudo-mandatory standard, consumers preferring the less stringent standard meat (consumers from group 2 and 3) product experience a negative trade-off as this product is no longer offered. Such consumers will switch towards the more stringent standard meat product when the utility derived from the more stringent standard meat product exceeds the utility derived from the substitute product (consumers from group 2). Consumers experiencing a negative trade-off such that the utility derived from the meat product entailing a more stringent standard is below the utility derived from the substitute, will switch towards the substitute (consumer group 3). Consequently, the retailer condition (no decrease in profits) may not be satisfied when imposing a more stringent standard.

The more stringent standard may interact with another standard, affecting the disutility associated with the negative externalities of the meat product. In case of independent standards, the interaction between two standards does not affect the 
disutility associated with the other externalities when changing one of these standards. A conflict between two standards implies that the increase in a standard (e.g. AW) enhances the disutility associated with the other externalities of another standard (e.g. greenhouse gas emissions). Therefore, the number of consumers preferring the higher standard meat product over the lower standard meat product and the substitute decreases, relative to the case of independent standards. In contrast, synergy between the standards implies that an increase in a standard generates a decrease in the disutility associated with the other externalities, relative to separate standard assessment, when increasing a standard. As a result, the number of consumers preferring the higher standard meat product over the lower standard meat product and the substitute increases, relative to the case of independent standards. Appendix 2A provides a mathematical substantiation of these effects.

\subsection{Empirical application}

\subsubsection{New Dutch Retail Standard}

The conceptual framework presented in the previous section was applied to the introduction of the New Dutch Retail Standard (NDRS) in 2014-2015, a pseudomandatory standard on AW. Prior to its introduction in 2014, Dutch retailers supplied meat from broilers in conventional production systems that met the minimum legal EU requirements on AW (Saatkamp et al., 2019). Under pressure of AW organizations, Dutch retailers replaced the conventional system by the NDRS system in 2014-2015. The main changes of the NDRS system vis-à-vis the conventional system are a slower-growing breed and a lower stocking density. Broiler farmers can still use the conventional system for export markets. Since the NDRS system does not include investments affecting total annual fixed costs, farmers are flexible in adopting either the conventional or NDRS system.

The changes of the NDRS system affect not only AW, but also antibiotic use, greenhouse gas emissions, ammonia emissions and particulate matter emissions. These effects may affect consumer valuation. A slower-growing breed has a higher feed intake than a fast-growing breed, and thus the greenhouse gas emissions per broiler increase (Bokkers \& De Boer, 2009). However, a slower-growing breed is less susceptible to disease, leading to a lower use of antibiotics in the NDRS system relative to the conventional system (Van Geijlswijk et al., 2019). The NDRS system extends the production period of the broiler and stimulates the activity of the broiler (Vissers et al., 2021c), elevating ammonia and particulate matter emissions. All these externalities are included in the model to calculate the 


\section{Chapter 2}

societal costs and benefits associated with Dutch broiler production before and after the introduction of the NDRS system.

\subsubsection{Model}

A partial equilibrium model has been developed to simulate the short-run effects of the introduction of the NDRS. Only the NDRS and conventional production system were considered, since these are the two dominant systems in the Netherlands (Saatkamp et al., 2019). Other production systems, such as organic or those from broiler meat substitutes, are ignored. To reflect the situation of the Netherlands as a net exporter of broiler meat, the model includes a rest of the world import demand function (Agrimatie, 2015). Producers are assumed to operate in a perfectly competitive market. Based on the theory of contestable markets (Baumol et al., 1983), retailers are assumed to operate in a competitive manner. Inputs were expressed in annual poultry housing capacity in $\mathrm{kg}$. A market share parameter has been added to the domestic demand functions to simulate the introduction of the NDRS. The partial equilibrium model includes constant elasticity demand and supply functions. The model solves for the optimal allocation of inputs to conventional and NDRS broiler meat production by maximizing aggregated producer surplus minus aggregated consumer expenditure, subject to available production capacity (defined as annual poultry housing capacity in $\mathrm{kg}$ ), and market clearing conditions. Appendix 2B gives a detailed description of the empirical model.

\subsubsection{Data}

The partial equilibrium model was calibrated for the base year 2013, which depicts the situation before the introduction of the NDRS. Information on the broiler market balance (production, consumption, net exports) was gathered from Agrimatie (2015). The producer price of conventional broilers was obtained from Agrimatie (2018). The price premium for broilers produced in the NDRS system was obtained from Blanken et al. (2019). Consumer price of conventional and NDRS broiler meat were derived from Gocsik et al. (2013) and Albert Heijn (2018), respectively, and were both corrected for inflation using the meat price index (CBS, 2018). All prices and quantities were expressed per kg carcass weight, which is $70 \%$ of the broiler's live weight as delivered from the farm (Van Horne, 2017). As no data was found on slaughter and handling costs, they were excluded from the model. This exclusion implies that retailer profits are most likely overestimated, although relative differences remain unaffected. The greenhouse gas, ammonia and particulate matter emission originating from the conventional 
and NDRS system were obtained from Rougoor and Van der Schans (2019) and Vissers et al. (2021c). The societal costs associated with these emissions were obtained from the Dutch Ministry of Infrastructure and Water Management (2020). To our knowledge, no study assessed the consumer valuation of reduced antibiotic use in the Netherlands ${ }^{2}$. To illustrate the potential societal benefits that might arise from reduced antibiotic use in the NDRS system, a consumer WTP of $€ 0.10 / \mathrm{kg}$ carcass weight for reduced antibiotic use is assumed. Price elasticities of demand and supply were obtained from Gallet (2010) and FAPRI (2019). The price elasticity of demand and supply is assumed to be equal for both systems. No data was found on the price elasticity of demand from rest of the world for broiler meat. As the EU broiler market is highly competitive (Van Horne, 2017), a price elasticity of export supply of -10 is assumed. Appendix $2 \mathrm{C}$ provides an overview of the data that has been used for calibration of the model.

\subsubsection{Results}

Table 2.1 shows the short-run effects of the introduction of the NDRS. The base year solution represents the situation before the introduction of the NDRS: approximately $38 \%$ of total production went to the domestic market while the remaining $62 \%$ was exported. Following the introduction of the NDRS system, approximately $38 \%$ of broiler production shifted from conventional to NDRS. As a result, the supply of conventional broilers to the export market decreased by 69.6 million $\mathrm{kg}(-12.9 \%)$. Although the consumer price for broiler meat increased by $€ 0.94 / \mathrm{kg}$, domestic demand (and thus domestic supply) for broiler meat increased by 0.2 million $\mathrm{kg}(+0.1 \%)$.

The introduction of the NDRS led to increased welfare for all supply chain actors (producer, retailer, and consumer). Hence, all three incentive-compatibility conditions were satisfied. Retailers had the largest gain in welfare $(+237.8$ million euro), followed by consumers ( +34.2 million euro) and producers $(+2.9$ million euro). The relatively large welfare increase for retailers can be explained by the higher absolute gross profit margin $(€ 3.31 / \mathrm{kg})$ earned over NDRS broiler meat compared to conventional broiler meat $(€ 2.62 / \mathrm{kg})$. The increase in consumer

\footnotetext{
${ }^{2}$ Some studies, such as Lusk et al. (2006), assessed consumer WTP for antibiotic free meat in the United States. Lusk et al. (2006) found that the average WTP for antibiotic free pork over regular pork was $\$ 1.86$ per choice. As growth promotors are banned in the EU, and antibiotics are still used in the NDRS system, consumer WTP associated with reduced antibiotic use in the NDRS system is most likely lower than the WTP found by Lusk et al. (2006).
} 


\section{Chapter 2}

Table 2.1 Summary of model results before and after the introduction of the NDRS (in $\mathrm{kg}$ carcass weight)

\begin{tabular}{|c|c|c|c|}
\hline Variable & Unit & Before & After \\
\hline \multicolumn{4}{|l|}{ Production } \\
\hline Conventional & Million kg & 888.0 & 476.4 \\
\hline NDRS & Million kg & - & 342.2 \\
\hline Total & Million kg & 888.0 & 818.6 \\
\hline \multicolumn{4}{|l|}{ Consumption } \\
\hline Conventional & Million kg & 342.0 & - \\
\hline NDRS & Million kg & - & 342.2 \\
\hline Total & Million kg & 342.0 & 342.2 \\
\hline Net exports & & 546.0 & 476.4 \\
\hline \multicolumn{4}{|l|}{ Producer price } \\
\hline Conventional & $€ / \mathrm{kg}$ & 1.31 & 1.33 \\
\hline NDRS & $€ / \mathrm{kg}$ & - & 1.56 \\
\hline \multicolumn{4}{|l|}{ Consumer price } \\
\hline Conventional & $€ / \mathrm{kg}$ & 3.93 & - \\
\hline NDRS & $€ / \mathrm{kg}$ & - & 4.87 \\
\hline Producer surplus & Million euro & $1,147.6$ & $1,150.4$ \\
\hline Retailer gross profits & Million euro & 894.6 & $1,132.4$ \\
\hline Consumer surplus & Million euro & $9,386.1$ & $9,420.3$ \\
\hline \multicolumn{4}{|l|}{ Potential societal benefits ${ }^{3}$} \\
\hline Antibiotic residues & Million euro & 0 & 34.2 \\
\hline \multicolumn{4}{|l|}{ Societal costs } \\
\hline Greenhouse gas emissions & Million euro & 129.4 & 124.3 \\
\hline Ammonia emissions & Million euro & 104.0 & 105.6 \\
\hline Particulate matter emissions & Million euro & 49.2 & 55.2 \\
\hline Social welfare & Million euro & $11,145.6$ & $11,452.3$ \\
\hline
\end{tabular}

surplus can be explained by the increase in consumer valuation from the NDRS system exceeding the increase in consumer price $(+€ 0.94 / \mathrm{kg})$, therefore incrementing consumer surplus. Producer surplus increased as the price effect (higher profit per animal) outweighed the quantity effect (lower annual output per $\mathrm{m}^{2}$ ) in the NDRS system. Potential societal benefits from reduced antibiotic use were small ( +34.2 million euro). The societal costs associated with greenhouse gas emission decreased marginally (-5.1 million euro), while the societal costs associated with ammonia and particulate matter emission increased marginally $(+1.6$ million euro and +6.0 million euro respectively). Social welfare reflects the

${ }^{3}$ Note that although improved animal welfare can be perceived as a societal benefit, it is already included in the consumer surplus. To prevent double counting, this benefit has not been included in the societal benefits. 
sum of producer surplus, retailer profits, consumer surplus and societal benefits minus societal costs. When attaching equal weights to the welfare of each group, social welfare increased by approximately 300 million euro after introduction of the NDRS.

\subsection{Discussion and policy implications}

\subsubsection{Discussion}

This paper developed a framework for analyzing the effects of multiple standards that address negative externalities resulting from meat production. The framework considers three incentive-compatibility conditions that need to be satisfied for a more stringent standard to be commercially feasible. It has been demonstrated that standards may interact with one another, thereby causing synergistic or conflicting effects. These interaction effects evoke interesting questions associated with standards. For instance, what is the rationale of making a standard more strict? What impact will this standard have on direct and indirect costs and benefits, of some of which may be marketable and others may not? The framework has been applied to the case of the Dutch broiler sector, where a pseudo-mandatory standard was introduced based on a broad stakeholder consensus, over and above the existing minimum legal standard. The framework helps to understand under which conditions such a standard could be commercially feasible.

Earlier studies on the introduction of more stringent standards, such as Saitone et al. (2015) and Segerson (2013) analyzed the welfare effects and requirements for success in a voluntary setting. Segerson (2013) states that an effective voluntary standard must provide strong participation incentives, clearly identify standards and monitor outcomes. The market potential of a voluntary standard may be limited by free-riding of consumers, i.e. consumers benefiting from the purchases of others without paying the associated cost themselves. Our framework demonstrates that a pseudo-mandatory standard, which limits consumer choice, can be used to overcome this issue. In line with our framework, Saitone et al. (2015) demonstrates that a limitation of consumer choice will cause distributional effects among consumers. Producers gain welfare only in case most consumers prefer the product entailing a more stringent standard or in case their WTP is large. However, Saitone et al. (2015) consider the limiting consumer choice phenomena only in mandatory standard setting, thus ignoring the case of a pseudo-mandatory standard. As such, the pseudo-mandatory setting is similar to a mandatory one, but requires commercial feasibility, i.e. compatible incentives for all chain actors, including consumers. This is not relevant in a mandatory setting since there is legal 


\section{Chapter 2}

enforcement of the standard. To our knowledge, this is the first study that analyzes the commercial feasibility of standards in a pseudo-mandatory setting. It also is the first study that demonstrates how synergistic and conflicting effects at producer and consumer level are relevant in evaluating the pros and cons of such standards. The framework provides a better understanding of private initiatives that make consumers contribute to improved sustainability, which is considered as key priority in food policy research (Lusk \& McCluskey, 2018).

The empirical application of our multiple-standards framework concerns the NDRS, a pseudo-mandatory standard on AW introduced in the Dutch domestic poultry market. Our results of showed that, although broiler meat became more expensive for consumers, domestic demand was virtually not affected $(+0.1 \%)$. As the NDRS system requires more square meter poultry housing surface per animal, relative to the conventional production system, total broiler volume decreased. The decrease in supply mainly occurred at the export market $(-12.9 \%)$, leaving supply at the domestic market practically unaffected $(+0.1 \%)$. These model simulation findings are supported by data, which showed a slight increase in domestic production and consumption $(+0.3 \%$ and $+0.3 \%)$ in the period $2013-2016$ (Agrimatie, 2015). In contrast to our simulation results, there was an increase in the net exports of broiler meat $(+28.1 \%)$, which can be explained by the strong increase in net imports of broilers $(+59.6 \%)$. The results of the empirical application also showed that all three incentive-compatibility conditions (producer, retailer, consumer) were satisfied as additional benefits occurred for producers $(+2.9$ million euro), retailers $(+237.8$ million euro $)$, as well as consumers $(+34.2$ million euro). The findings show that market failure related to production externalities can be successfully addressed by pseudo-mandatory standards, provided that all three incentive-compatibility conditions are satisfied.

Our empirical application abstracted from reality in ways that are discussed next. Firstly, it is assumed that producers are willing to adopt a more stringent standard on the condition that it does not lower their profits. Other factors of influence, such as the non-use value, are not considered. The non-use value refers to the 'intrinsic' value that producers derive from adhering to specific farming practices (Lagerkvist et al., 2011), so that a farmer may adopt a more stringent standard even when it is economically burdensome. Our study is restricted to standard adoption purely from an economic perspective. 
Secondly, while Dutch consumers prefer to purchase cut-up chicken meat, such as breasts, wings and legs (Bokkers \& De Boer, 2009), the empirical application focused only on chicken meat as a whole. Shortly after the introduction of the NDRS system, chicken breast originating from this system was sold by retailers, whereas other cut-up parts were processed by the food industry or exported. Accordingly, the increase in production costs due to higher standards had to be transferred primarily to the price of chicken breast. However, the NDRS system has developed in the past years such that nearly all parts (95-100\%) of the broiler are sold at a price premium (P.L.M. Van Horne, personal communication, November 12, 2019).

Thirdly, the framework did not consider the impact of more stringent standards on the profitability of other chain actors such as input suppliers and processors. In case of the introduction of the NDRS, two opposite forces occurred: a higher feed conversion rate of the broilers (more feed required per animal produced) and a lower stocking density (less feed required per $\mathrm{m}^{2}$ ) relative to the conventional system. Depending on the impact of both forces, farmers switching towards the NDRS system may require less feed, thereby negatively affecting feed supplier's turnover (assuming poultry housing capacity to be fixed). Since expansion of production capacity in the Netherlands is constrained by institutional factors (such as environmental regulations), the introduction of the NDRS resulted in a reduction of Dutch broilers in the period 2015-2016 (Agrimatie, 2015). As a result, slaughterhouses and processors had an overcapacity in the short term. The slaughterhouses and processors offered conventional producers a higher price to attract more broilers. As a result, more broilers were imported (and exported thereafter) to ensure full utilization of production capacity (Agrimatie, 2015). These imports increased transportation and transaction costs for slaughterhouses, which were covered by instating a higher processor price. However, this price effect is expected to be only temporary, as production abroad may expand to fill up the gap in supply caused by the lower production volume in the Netherlands. Future research should include the welfare effects on input suppliers and processors to obtain better insight in the willingness of all chain actors to implement more stringent standards.

\subsubsection{Policy implications}

The multiple-standards framework can aid research for policy support by analyzing the welfare effects of voluntary and pseudo-mandatory standards in a multiple actor supply chain-context. This insight is particularly relevant when the public 


\section{Chapter 2}

standard is considered too low from a social welfare point of view. This so-called 'understandardization' may result from successful lobbying by interest groups (Swinnen et al., 2015), and/or national standards that are following international standards (e.g. EU standards) that 'lag behind' national preferences. Voluntary or pseudo-mandatory standards, which go beyond the public legal standard, can enhance social welfare in case of understandardization. Standard anti-trust reasoning, however, would be critical to such collective private sector 'agreements', since they could lead to an abuse of economic power at the costs of consumer interests and consumer freedom. We show that such collective private sector agreements do not necessarily contradict the interests of consumers and may even contribute to solving the problem of 'understandardization'. We show that when taking into account the aggregate net benefits arising from potential interaction effects on externalities, there could even be an argument for governments to, under specific conditions, facilitate and/or support a pseudomandatory standard going beyond what is required from a legal minimum perspective.

Figure 2.2 shows a differentiated picture of the various cases that should be distinguished. The cases vary based on the commercial feasibility of the pseudomandatory standard and the different net benefits arising from interaction with other standards and their effects on (other) externalities. If the pseudo-mandatory standard is commercially feasible (i) (i.e. the standard does not lower both aggregated producer profits, retailer profits and consumer surplus), no state support is required to introduce this standard. In case the pseudo-mandatory standard (e.g. on AW) causes synergy on another standard (e.g. on antibiotic use) (ia), multiple externalities are addressed simultaneously. Such synergistic effects would provide an argument for the government to facilitate the pseudo-mandatory standard. In case the standard conflicts with one or more other standards (ib), one externality is addressed while no indirect 'benefits' result with respect to these other externalities. Because of these conflicting effects, the government could decide to facilitate or forbid this standard, depending on the outcome of a critical weighing of all (direct and indirect) benefits and losses. If there is no interaction with another standard (ic), the government should be careful with the facilitation of the new standard. Although the pseudo-mandatory standard enhances welfare (on aggregate) in its own right, the government will have to take into account the distributional impact of the standard on consumers and consumer freedom. 


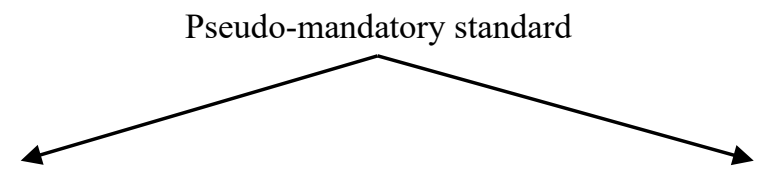

(i) Commercially feasible

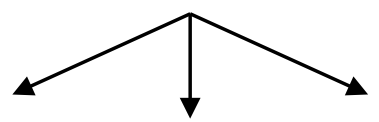

(ia) Synergistic (ib) Conflicting (ic) No effect effect

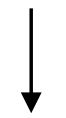

Facilitate

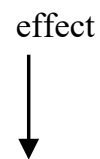

Cautious

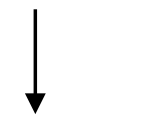

Might facilitate (ii) Commercially not feasible

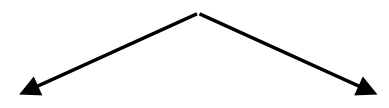

(iia) Synergistic

(iib) Conflicting effect or no effect

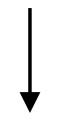

Targeted subsidization (hybrid system)

Figure 2.2 Decision tree on the justification of government facilitation and support of the pseudo-mandatory standard

If the pseudo-mandatory standard is not commercially feasible (ii), the newly proposed pseudo-mandatory standard is evaluated as 'a bridge too far' in terms of the private sector benefit/cost trade-off. Therefore, government support would be required for its introduction. In case the pseudo-mandatory standard causes synergy on one or more other standards (iia), the indirect 'side benefits' of the synergistic effect could justify targeted support of the pseudo-mandatory standard. However, in case the pseudo-mandatory standard conflicts with other standards or has negative trade-offs with respect to other externalities (iib), there is no case for governmental support of its introduction. Moreover, without government support, the pseudo-mandatory standard will clearly be a non-starter in this case.

\subsection{Concluding remarks}

The framework developed in this paper provides a scientific basis for an ex ante analysis of the market potential of pseudo-mandatory standards in the context of multiple standards or externalities context. The framework takes into account welfare effects and the relevant incentive-compatibility conditions. The empirical application of the framework to the New Dutch Retail Standard in the Dutch broiler market demonstrated that for this case all three incentive-compatibility conditions were satisfied to support a successful introduction. The side benefits from related externalities also turned out to be positive. This case demonstrates that 


\section{Chapter 2}

a pseudo-mandatory standard that goes beyond a legal or public minimum standard can be welfare enhancing in a context of 'understandardization'. Depending on the specific conditions, governments should consider a differentiated response to such standards (facilitate, support, caution), which goes beyond the classical anti-trust response of prohibiting private sector 'agreements' affecting market conditions. Future research should focus on the development of more elaborated quantitative value chain models that include interaction effects and allow an ex ante analysis of price incentive-compatibility issues. These interaction effects can provide better insight into how the introduction of a pseudo-mandatory standard can potentially erode the impact and investments in voluntary standards.

\section{Acknowledgements}

This work was financially supported by the Food Pro-tec-ts project. This project is carried out within the framework of the INTERREG V A program "DeutschlandNederland" and is co-financed by the European Regional Development Fund (ERDF) and the Dutch Ministry of Economic Affairs and Climate Change, the Ministry of Economic Affairs, Innovation, Digitalization and Energy of North Rhine-Westphalia and the provinces of Gelderland, Limburg and North Brabant. It is accompanied by the program management at the Euregio Rhein-Waal.

\section{Appendix}

\section{Appendix 2A. Technical appendix}

Producer

The producer's profit function can be written as:

$$
\pi^{P}\left(p^{P}, v, q^{S}, \boldsymbol{s}, k\right)=\max _{q^{S}}\left[p^{P}(\boldsymbol{s}) q^{S}(\boldsymbol{s})-v(q, \boldsymbol{s}) q^{S}(\boldsymbol{s})-k\right]
$$

where $\pi^{P}=$ producer profits; $p^{P}=$ producer price; $q^{S}=$ output supply; $v=$ variable costs; $k=$ fixed costs; $\boldsymbol{s}=$ vector of multiple standards $\left(s_{i} \ldots s_{n}\right)$ in the positive domain $(s \geq 0)$. The producer price is either unaffected by the standard or increased with the intensity of the standard $\left(\frac{d p^{P}(s)}{d s_{i}} \geq 0\right)$. Per unit variable costs are assumed to be increasing and strictly convex in the intensity of the standard $\left(\frac{\delta v\left(q^{S}, s\right)}{\delta s_{i}}>0 \forall_{i} ; \frac{\delta^{2} v\left(q^{S}, s\right)}{\delta s_{i} * \delta s_{i}}>0 \forall_{i}\right)$. An increase in a standard decreases production (ceteris paribus) $\left(\frac{d q^{S}(s)}{d s_{i}}<0\right)$ The effect of the interaction of standard $s_{j}$, with respect to $s_{i}$ on variable costs, is written as: 


\section{Effect}

Independent

Mathematical notation

$$
\frac{\delta^{2} v}{\delta s_{i} * \delta s_{j}}=0
$$

Conflicting

$$
\frac{\delta^{2} v}{\delta s_{i} * \delta s_{j}}>0
$$

Synergy

$$
\frac{\delta^{2} v}{\delta s_{i} * \delta s_{j}}<0
$$

\section{Description}

Interaction effect does not affect variable costs

Interaction effect causes an additional increase in per unit variable costs Interaction effect causes a decrease in per unit variable costs

\section{Retailer}

The retailer's profits profit function can be written as:

$$
\pi^{R}\left(p^{C}, p^{P}, q^{S}, l, \mathbf{s}\right)=\max _{q^{S}}\left[\left(p^{C}(\boldsymbol{s})-p^{P}(\boldsymbol{s})-l\right) q^{S}(\boldsymbol{s})-h\left(q^{S}\right)\right]
$$

where: $\pi^{R}=$ retailer's profits; $p^{C}=$ retailer's selling price; $l=$ slaughter costs. A more stringent standard at farm level would result in an increase of the producer price, and therefore an increase in the retailer's marginal costs. To prevent a decrease in the retailer's profits, an increase in consumer price covering the additional costs is required. The consumer price is increasing and concave in standards $\left(\frac{\delta p^{C}}{\delta s_{i}}>0 \forall_{i} ; \frac{\delta^{2} p^{C}}{\delta s_{i}^{*} \delta s_{i}}<0 \forall_{i}\right)$.

\section{Consumer}

Based on the model of Plastina and Giannakas (2007), it is assumed in the framework that individuals consume one unit of the product and select the product that provides them most utility. The utility functions of a consumer are derived from Plastina and Giannakas (2007) and shown in equation (6), (7), and (8).

$$
\begin{gathered}
U\left(s_{i}^{0} ; \check{\boldsymbol{s}}\right)=U^{B}-\mu\left(s_{i}^{0} ; \check{\boldsymbol{s}}\right) m-p^{C}\left(s_{i}^{0} ; \check{\boldsymbol{s}}\right) \\
U\left(s_{i}^{1} ; \check{\boldsymbol{s}}\right)=U^{B}-\mu\left(s_{i}^{1} ; \check{\boldsymbol{s}}\right) m-p^{C}\left(s_{i}^{0} ; \check{\boldsymbol{s}}\right) \\
U^{s u}=U^{B}-\lambda m-p^{S U}
\end{gathered}
$$

where: $U\left(s_{i}^{0} ; \check{\boldsymbol{s}}\right)=$ utility associated with unit consumption of the less stringent standard meat product; $U\left(s_{i}^{1} ; \check{\boldsymbol{s}}\right)=$ utility associated with unit consumption of the more stringent standard meat product; $U^{s u}=$ utility associated with unit consumption of the substitute product; $s_{i}=$ standard $i ; \check{\boldsymbol{s}}=$ other standards $\left(s_{j}^{0}, j=\right.$ $1 \ldots n, j \neq i) ; p^{C}=$ consumer price of the meat products; $U^{B}=$ base level of utility (such as texture and taste) derived from the product related traits; $p^{S U}=$ price of 


\section{Chapter 2}

the substitute; $\mu=$ non-negative utility discount factor associated with negative externalities of the meat product ; $\lambda=$ non-negative utility discount factor associated with negative externalities of the substitute; $m=$ indicator differentiating consumers with respect to their attitude to the negative externalities associated with meat consumption. This parameter is uniformly distributed over the interval $m \in\{0, M\}$. The parameter $\mu$ is assumed to be decreasing and concave in standards $\left(\frac{\delta \mu}{\delta s_{i}}<0 \forall_{i} ; \frac{\delta \mu}{\delta s_{i} * \delta s_{i}}<0 \forall_{i}\right)$. It is assumed that $p^{S U}>p^{C}\left(s_{i}^{1} ; \check{\boldsymbol{s}}\right)>$ $p^{C}\left(s_{i}^{0} ; \check{\boldsymbol{s}}\right)$. A graphical representation of the utility functions is provided in Figure A1. Consumers where $m<m_{s_{0}}$ will prefer the less stringent standard meat product, whereas consumers where $m_{s_{0}}<m<m_{s_{1}}$ will prefer the more stringent standard product. Consumers where $m>m_{s_{1}}$ will prefer the substitute product.

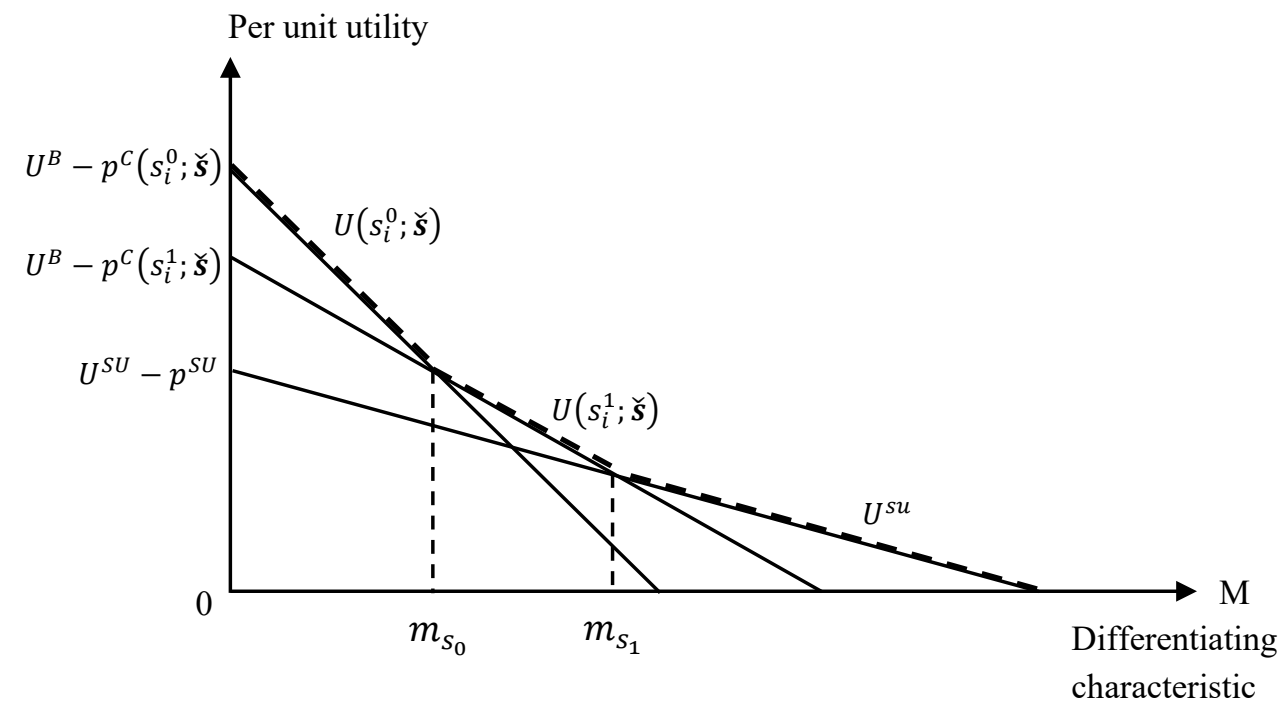

Figure A1 Consumer preferences of the less stringent standard product, more stringent standard product and substitute product. The dashed line reflects consumer preferences The effect of the interaction between standard $s_{j}$ and $s_{i}$ on non-negative utility discount factor $\mu$ can be written as:

Effect

Independent
Mathematical notation

$$
\frac{\delta \mu}{\delta s_{i} * \delta s_{j}}=0
$$

\section{Description}

Interaction effect does not affect the utility discount factor 
A multiple-standards framework

Conflicting

$$
\frac{\delta \mu}{\delta s_{i} * \delta s_{j}}<0
$$

Interaction effect causes an increase in the utility discount factor

Synergy

$$
\frac{\delta \mu}{\delta s_{i} * \delta s_{j}}>0
$$

Interaction effect causes an additional decrease in the utility discount factor

\section{Appendix 2B. Description of model}

The supply and demand for conventional and NDRS are displayed using constant elasticity functions. A binary variable has been included in both consumer demand functions to display the introduction of the NDRS system. Additionally, a parameter is included in both demand functions, which is increasing in standards, to display the change in WTP. The parameter of the supply function reflects the production efficiency, which is decreasing in standards. The supply function of the NDRS system also includes an inefficiency parameter reflecting the higher production capacity per animal (from lower stocking density) and less rounds per year (from lower growth rate of the broilers) of the NDRS system relative to the conventional system. The systems were classified as $i$ players, where $i=1$ and $i=2$ reflect the conventional and NDRS systems respectively. The model solves for the optimal allocation of inputs to conventional and NDRS broiler meat production by maximizing aggregated producer surplus minus aggregated consumer expenditure, subject to available production capacity (defined as total annual poultry housing capacity in $\mathrm{kg}$ ), and market clearing conditions ${ }^{4}$.

$$
\begin{gathered}
Q_{i}^{S}=\alpha\left(s_{i}\right) x_{i} p_{i}^{P^{\gamma}} \text { and } Q_{i}^{D}=\beta \theta\left(s_{i}\right) p_{i}^{C^{\varepsilon}} \\
Q_{1}^{I D}=\mu p_{1}^{P^{\tau}} \\
x_{1}=Q_{1}^{S} *\left(1+m_{1}\right) \text { and } x_{2}=Q_{2}^{S} *\left(1+m_{2}\right) * f \\
f=\frac{d_{1} * r_{1}}{d_{2} * r_{2}} \\
\operatorname{Max} \pi^{P}-C E \text { s.t. } x_{1}+x_{2} \leq \bar{X} \quad \text { s.t. } \quad Q_{1}^{S}=Q_{1}^{I D} \text { and } Q_{2}^{S}=Q_{2}^{D}
\end{gathered}
$$

where: $Q_{i}^{S}=$ supply function system i; $\alpha=$ parameter production function; $x=$ inputs defined as poultry housing surface in $\mathrm{kg} ; p_{i}^{P}=$ producer price system $\mathrm{i} ; \gamma=$ price elasticity of supply; $Q_{i}^{D}=$ demand function system i; $\beta=$ consumer share parameter; $\theta=$ parameter demand function; $s_{i}=$ standard system $\mathrm{i} ; p_{i}^{C}=$ consumer price system $\mathrm{i} ; \varepsilon=$ price elasticity

\footnotetext{
${ }^{4}$ A maximum consumer price of $€ 50 / \mathrm{kg}$ is assumed when calculating consumer surplus
} 


\section{Chapter 2}

of domestic demand; $Q_{1}^{I D}=$ demand function rest of the world; $\mu$ = parameter demand function rest of the world; $\tau=$ price elasticity of demand rest of the world; $m_{i}=$ mortality rate system i; $f=$ inefficiency factor NDRS system; $d_{i}=$ stocking density system $\mathrm{i} ; r_{i}=$ rounds per year system i; $\pi^{P}=$ producer surplus; $C E=$ consumer expenditure, $\bar{X}=$ production capacity in poultry housing surface in $\mathrm{kg}$

Appendix 2C. Data used for model calibration

Table C1. Overview of data

\begin{tabular}{|c|c|c|c|c|}
\hline Item & Parameter & Unit & Conventional & NDRS \\
\hline Production & $Q^{S}$ & million $\mathrm{kg}$ carcass weight & $888.0^{1}$ & - \\
\hline Consumption & $Q^{D}$ & million kg carcass weight & $342.0^{1}$ & $343.0^{1}$ \\
\hline Net exports & $Q^{I D}$ & million $\mathrm{kg}$ carcass weight & $546.0^{1}$ & - \\
\hline Mortality rate & $m$ & $\%$ & $3.50^{2}$ & $3.00^{2}$ \\
\hline Stocking density & $d$ & $\mathrm{~kg} / \mathrm{m}^{2}$ & $42.0^{2}$ & $38.0^{2}$ \\
\hline Rounds per year & $r$ & $\#$ & $7.5^{2}$ & $6.8^{2}$ \\
\hline $\begin{array}{l}\text { Price elasticity of } \\
\text { supply }\end{array}$ & $\gamma$ & & $0.56^{3}$ & $0.56^{3}$ \\
\hline $\begin{array}{l}\text { Price elasticity of } \\
\text { domestic demand }\end{array}$ & $\varepsilon$ & & $-0.65^{4}$ & $-0.65^{4}$ \\
\hline $\begin{array}{l}\text { Price elasticity of } \\
\text { demand rest of world }\end{array}$ & $\tau$ & & -10 & - \\
\hline Producer price & $p^{P}$ & $€ / \mathrm{kg}$ live weight & $0.92^{5}$ & $1.08^{5}$ \\
\hline Consumer price & $p^{C}$ & $€ / \mathrm{kg}$ carcass weight & $3.93^{6}$ & $4.85^{7}$ \\
\hline
\end{tabular}




\section{References}

Agrimatie. (2015). Voorzieningsbalansen. Retrieved from https://www.agrimatie.nl/VoorzieningsBalansen.aspx

Agrimatie. (2018). Agrarische prijzen. Retrieved from https://www.agrimatie.nl/Prijzen.aspx?ID=15125

Albert Heijn. (2018). AH hele kip. Retrieved from https://www.ah.nl/producten/product/wi39978/ah-hele-kip

Baumol, W. J., Panzar, J., \& Willig, R. (1983). Contestable markets: an uprising in the theory of industry structure. American Economic Review, 73(3), 491496. doi:www.jstor.org/stable/1808145

Blanken, K., De Buisonje, F., Evers, A. G., Ouweltjes, W., Verkaik, J. C., Vermeij, I., \& Wemmenhove, H. (2019). KWIN 2019-2020: Wageningen University \& Research.

Bokkers, E. A. M., \& De Boer, I. J. M. (2009). Economic, ecological, and social performance of conventional and organic broiler production in the Netherlands. British Poultry Science, 50(5), 546-557. doi:https://doi.org/10.1080/00071660903140999

CBS. (2018). Consumentenprijsindex; 2015=100. Retrieved from: http://statline.cbs.nl/Statweb/publication/?DM=SLNL\&PA=83131NED\& $\mathrm{D} 1=4 \& \mathrm{D} 2=12 \& \mathrm{D} 3=220 \% 2 \mathrm{c} 233 \% 2 \mathrm{c} 246 \% 2 \mathrm{c} 259 \% 2 \mathrm{c} 272 \% 2 \mathrm{c} 285 \& \mathrm{HDR}=$ $\mathrm{T} \& \mathrm{STB}=\mathrm{G} 2 \% 2 \mathrm{cG} 1 \& \mathrm{VW}=\mathrm{T}$

De Jonge, J., \& Van Trijp, H. C. M. (2013). Meeting heterogeneity in consumer demand for animal welfare: A reflection on existing knowledge and implications for the meat sector. Journal of Agricultural and Environmental Ethics, 26(3), 629-661. doi:https://doi.org/10.1007/s10806012-9426-7

Dutch Ministry of Infrastructure and Water Management. (2020). Kengetallen Leefomgeving. Retrieved from https://www.rwseconomie.n1/kengetallen/kengetallen-leefomgeving.

Eurobarometer. (2016). Attitudes of Europeans towards animal welfare. Retrieved from

https://ec.europa.eu/commfrontoffice/publicopinion/index.cfm/ResultDoc/ download/DocumentKy/71348

Eurobarometer. (2017). Attitudes of European citizens towards the environment. Retrieved from https:/ec.europa.eu/public_opinion/archives/ebs/ebs 416 en.pdf.

Eurobarometer. (2019). Food Safety in the EU. European Commission Retrieved from

https://www.efsa.europa.eu/sites/default/files/corporate publications/files/ Eurobarometer2019 Food-safety-in-the-EU Full-report.pdf.

European Council Directive. Directive 2001/81/EC of the European Parliament and of the council of 23 October 2001 on national emission ceilings or certain atmospheric pollutants, (2001). 


\section{Chapter 2}

European Council Directive. Directive 2003/99/EC of the European Parliament and of the Council of 17 November 2003 on the monitoring of zoonoses and zoonotic agents, (2003).

European Council Directive. Directive 2008/120/EC of 18 December 2008 laying down minimum standards for the protection of pigs, (2008).

FAPRI. (2019). FAPRI Elasticity Database. Retrieved from: http://www.fapri.iastate.edu/tools/elasticity.aspx

Gallet, C. A. (2010). Meat meets meta: a quantitative review of the price elasticity of meat. American Journal of Agricultural Economics, 92(1), 258-272. doi:https://doi.org/10.1093/ajae/aap008

Gocsik, É., Brooshooft, S. D., De Jong, I. C., \& Saatkamp, H. W. (2016). Costefficiency of animal welfare in broiler production systems: A pilot study using the Welfare Quality ${ }^{\circledR}$ assessment protocol. Agricultural Systems, 146, 55-69. doi:https://doi.org/10.1016/j.agsy.2016.04.001

Gocsik, É., Oude Lansink, A. G. J. M., \& Saatkamp, H. W. (2013). Mid-term financial impact of animal welfare improvements in Dutch broiler production. Poultry Science, 92(12), 3314-3329. doi:https://doi.org/10.3382/ps.2013-03221

Gocsik, É., Van der Lans, I. A., Oude Lansink, A. G. J. M., \& Saatkamp, H. W. (2015). Willingness of Dutch broiler and pig farmers to convert to production systems with improved welfare. Animal Welfare, 24(2), 211222. doi:https://doi.org/10.7120/09627286.24.2.211

Lagerkvist, C. J., Hansson, H., Hess, S., \& Hoffman, R. (2011). Provision of Farm Animal Welfare: Integrating Productivity and Non-Use Values. Applied Economic Perspectives and Policy, 33(4), 484-509. doi:https://doi.org/10.1093/aepp/ppr037

Lusk, J. L., \& McCluskey, J. (2018). Understanding the Impacts of Food Consumer Choice and Food Policy Outcomes. Applied Economic Perspectives and Policy, 40(1), 5-21. doi:https://doi.org/10.1093/aepp/ppx054

Lusk, J. L., \& Norwood, F. B. (2011). Animal Welfare Economics. Applied Economic Perspectives and Policy, 33(4), 463-483. doi:https://doi.org/10.1093/aepp/ppr036

Lusk, J. L., Pruitt, J. R., \& Norwood, F. B. (2006). Consumer Demand for a Ban on Antibiotic Drug Use in Pork Production. American Journal of Agricultural Economics, 88(4), 1015-1033. doi:https://doi.org/10.1111/j.14678276.2006.00913.x

Plastina, A., \& Giannakas, K. (2007). Market and welfare effects of GMO introduction in small open economies. AgBioForum, 10(2), 104-123.

Reinders, M., Poppe, K. J., Immink, V., Van den Broek, E., Van Horne, P. L. M., \& Hoste, R. (2013). Waardevolle perspectieven voor vlees. Retrieved from Den Haag: https://edepot.wur.n1/296834

Rougoor, C., \& Van der Schans, F. (2019). Vergelijking milieueffecten vleeskuikenconcepten. Retrieved from https://www.pluimveeloket.be/sites/default/files/inline-files/2019- 
10\%20CLMrapport-Vergelijking milieueffecten vleeskuikenconcepten.pdf

Saatkamp, H. W., Vissers, L. S. M., Van Horne, P. L. M., \& De Jong, I. C. (2019). Transition from conventional broiler meat to meat from production concepts with higher animal welfare: experiences from The Netherlands. Animals, 9(8). doi:https://doi.org/10.3390/ani9080483

Saitone, T. L., Sexton, R. J., \& Sumner, D. A. (2015). What Happens When Food Marketers Require Restrictive Farming Practices? American Journal of Agricultural Economics, 97(4), 1021-1043. doi:https://doi.org/10.1093/ajae/aav021

Segerson, K. (2013). When Is Reliance on Voluntary Approaches in Agriculture Likely to Be Effective? Applied Economic Perspectives and Policy, 35(4), 565-592. doi:https://doi.org/10.1093/aepp/ppt030

Swinnen, J., Deconinck, K., Vandemoortele, T., \& Vandeplas, A. (2015). Quality standards, value chains, and international development: economic and political theory. New York: Cambridge University Press.

Van Geijlswijk, I. M., Heederik, D., Mouton, J. W., Wagenaar, J. A., Jacobs, J. H., \& Sanders, P. (2019). Usage of Antibiotics in Agricultural Livestock in the Netherlands in 2018. Retrieved from https://cdn.ipulse.nl/autoriteitdiergeneesmiddelen/userfiles/Publications/2018-defrapport1.pdf

Van Horne, P. L. M. (2017). Competitiveness of the EU poultry meat sector, base year 2015; International comparison of production costs. Retrieved from http://edepot.wur.nl/404949

Vissers, L. S. M., Saatkamp, H. W., \& Oude Lansink, A. G. J. M. (2021). Analysis of synergies and trade-offs between animal welfare, ammonia emission, particulate matter emission and antibiotic use in Dutch broiler production systems. Agricultural Systems, 189, 103070. doi:https://doi.org/10.1016/j.agsy.2021.103070 


\section{Chapter 3}

\section{Analysis of synergies and trade-offs}

between animal welfare, ammonia emission, particulate matter emission and antibiotic use in Dutch broiler production systems

Luuk S.M. Vissers, Helmut W. Saatkamp, Alfons G.J.M Oude Lansink

Published in Agricultural Systems. Volume 189, April 2021.

DOI: https://doi.org/10.1016/j.agsy.2021.103070 


\title{
Chapter 3
}

\begin{abstract}
Intensive broiler production systems are criticized by EU citizens because of their negative impact on animal welfare, the environment and human health. To inform the development of sustainable broiler production systems, this paper provides insight in the synergies and trade-offs between different external factors originating from broiler production systems by developing a new analysis approach. The approach was applied to the Dutch conventional, New Dutch Retail Standard and Extensive Indoor+ systems. The latter two systems have more stringent standards on animal welfare relative to the conventional system. Four external factors were considered, i.e. animal welfare (indicated by Welfare Quality Index score), ammonia emission ( $\mathrm{kg} \mathrm{NH}_{3}$ /animal place/year), particulate matter emission ( $\mathrm{g}$ $\mathrm{PM}_{10}$ /animal place/year) and antibiotic use (defined daily doses animal). Results show that the shift from a fast-growing breed towards a slower-growing breed caused synergy by improving animal welfare and lowering antibiotic use. Furthermore, the reduction in protein content of the feed, and possibly the reduction in stocking density, caused synergy by enhancing animal welfare and lowering ammonia emission. System changes that stimulated activity, such as the reduction in stocking density, enhanced animal welfare but caused a trade-off with particulate matter emission. Although the New Dutch Retail Standard and Extensive Indoor+ system were characterized by a higher ammonia and particulate matter emission per animal place per year relative to the conventional system, experts estimated that these emissions were partially (New Dutch Retail Standard) or fully (Extensive Indoor+) offset at farm level via a lower stocking density. Overall, we conclude that future development of broiler production systems can exploit the synergy between animal welfare, antibiotic use, and ammonia emission and minimize the trade-off between animal welfare and particulate matter emission. The insights obtained from this paper can support the development of sustainable broiler production systems that minimize external factors originating from these systems.
\end{abstract}

Keywords: Broiler production; Animal welfare; Ammonia; Particulate matter; Synergy; Trade-offs 


\subsection{Introduction}

EU citizens have expressed widespread concerns about the loss of biodiversity, the presence of antibiotic residues in meat, and the welfare of farmed animals (Eurobarometer, 2015, 2016, 2019b). Broiler production is an important source of these concerns through its negative side-effects, defined as external factors ${ }^{\mathrm{a}}$, on Animal Welfare (AW), the environment and human health (Homidan et al., 2003; Cambra-López et al., 2010; Bracke et al., 2019; Van Geijlswijk et al., 2019). Most prominent among the concerns in broiler production are the leg disorders that fastgrowing broilers may develop when reared in intensive production systems (Broom, 2017). In an attempt to increase awareness among citizens for the leg disorders, the Dutch NGO Wakker Dier introduced the term 'plofkip' ('exploding chicken'). In the past two decades, the EU passed legislation on AW, the environment and food safety associated with livestock production to resolve the societal concern (European Council Directive, 2007, 2009, 2016). However, the legislation is deemed to be insufficient as criticism persists as of today. To counteract the critique on AW, private chain actors introduced more extensive systems containing slower-growing breeds, such as the Label Rouge in France and Better Life in the Netherlands. Although these systems are found to improve AW (Bracke et al., 2019), these systems have a higher environmental burden (expressed per kg edible carcass weight) relative to the more intensive conventional systems (Leinonen et al., 2012). This suggests a trade-off where taking measures to address $\mathrm{AW}$, increase environmental issues.

The example above illustrates that external factors in broiler production are interrelated. Hence, the development of new broiler production systems requires a multi-dimensional approach that analyzes systems in terms of their economic, ecological, and social performance (Bokkers \& De Boer, 2009). So far, only Bokkers and De Boer (2009), Rocchi et al. (2019) and Gocsik et al. (2016a) used such a multi-dimensional approach. However, these studies have their shortcomings. While Bokkers and De Boer (2009) and Rocchi et al. (2019) considered multiple external factors in broiler production, they did not assess the individual contribution of system attributes, such as the broiler breed, to these external factors. Gocsik et al. (2016a) analyzed the contribution of system attributes to AW, but ignored the contribution of these attributes to environmental factors. Hence, neither Bokkers and De Boer (2009), nor Rocchi et al. (2019), nor

\footnotetext{
${ }^{a}$ In chapters 3 and 4, we use the term external factor. In the remainder of the dissertation we use the term externalities.
} 


\section{Chapter 3}

Gocsik et al. (2016a) considered the effect of changes in system attributes on multiple external factors, thus ignoring the potential synergies and trade-offs caused by these changes. To fill this gap in the literature, this paper aims to obtain insight in the synergies and trade-offs between external factors originating from broiler production systems by developing an approach that allows an analysis of these factors. This insight can support the development of sustainable broiler production systems that minimize external factors originating from these systems and the price premium required for its introduction.

\subsection{Approach}

\subsubsection{Overview of approach}

A five-step approach was developed and applied to existing Dutch broiler production systems to analyze the synergies and trade-offs in these systems. These steps are shown in Figure 3.1 and discussed in detail in the remainder of this section.

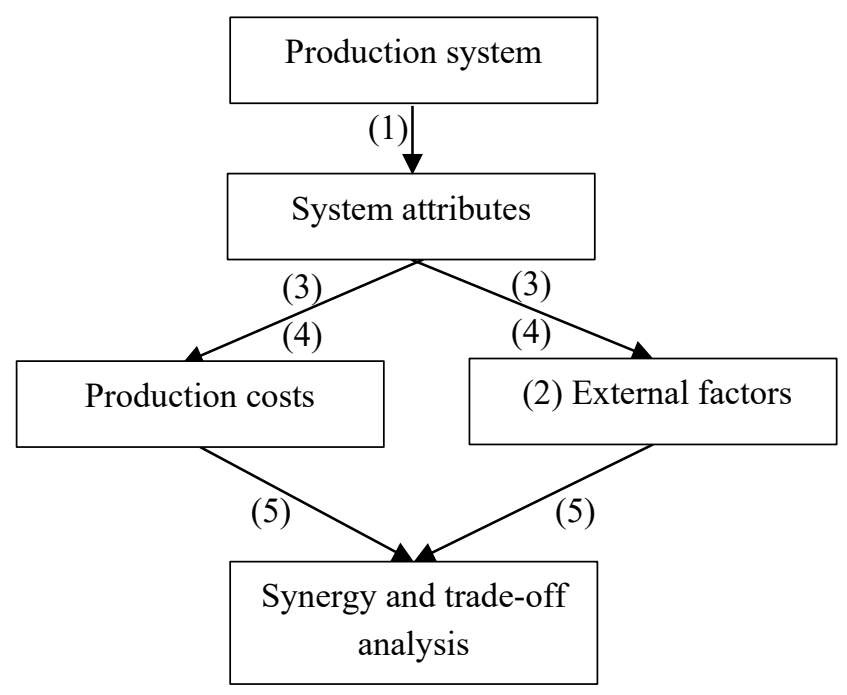

Figure 3.1 Overview of research approach

\subsubsection{Step 1: Decompose the production system into system attributes}

The Dutch conventional system, New Dutch Retail Standard (NDRS) and Extensive Indoor+ system were selected for the analysis as these systems are the prevailing ones in the Dutch broiler market. These systems were decomposed into system attributes. The Dutch conventional production system adheres to the minimum legal requirements on AW laid down by the European Council Directive (2007) and is mainly used for export markets (Vissers et al., 2019). The NDRS 


\section{Synergies and trade-offs between externalities}

contains the minimum AW requirements of Dutch retailers, which include a lower stocking density and a slower-growing breed relative to the minimum legal requirements. The Extensive Indoor+ system is specific to the Dutch market, produced under a national welfare label, and contains a covered veranda (indoor free-range area) and natural light entrance in the house. Table 3.1 shows the system attributes of all three systems.

Table 3.1 Overview of production system attributes of the selected production systems

\begin{tabular}{|c|c|c|c|c|}
\hline \multirow[t]{2}{*}{ System attribute } & \multirow[t]{2}{*}{ Unit } & \multicolumn{2}{|c|}{ Production system } & \multirow[b]{2}{*}{ Extensive Indoor+ } \\
\hline & & Conventional & NDRS & \\
\hline Broiler breed & Type & Ross $308^{1}$ & Hubbard JA987¹ & Hubbard JA757¹ \\
\hline $\begin{array}{l}\text { Length growth } \\
\text { period }\end{array}$ & Days & $39^{2}$ & $49^{2}$ & $56^{2}$ \\
\hline Weight at delivery & Grams & $2,380^{2}$ & $2,380^{2}$ & $2,380^{2}$ \\
\hline Stocking density & $\mathrm{Kg} / \mathrm{m}^{2}$ & $42^{1}$ & $38^{1}$ & $25^{1}$ \\
\hline $\begin{array}{l}\text { Straw bale } \\
\text { enrichment }\end{array}$ & $\begin{array}{l}\text { \# bales } / 1,000 \\
\text { broilers }\end{array}$ & $\mathrm{No}^{1}$ & $1^{1}$ & $1^{1}$ \\
\hline Grain enrichment & $\mathrm{g} / \mathrm{broiler}$ & $\mathrm{No}^{1}$ & $\mathrm{No}^{1}$ & $2^{1}$ \\
\hline Length dark period & Hours/day & $\begin{array}{l}6,4 \\
\text { uninterrupted }^{1}\end{array}$ & 6 , uninterrupted ${ }^{1}$ & 8 , uninterrupted ${ }^{1}$ \\
\hline Light intensity & $\operatorname{lux}$ & $20^{3}$ & $20^{3}$ & $20^{3}$ \\
\hline Natural light & $\begin{array}{l}\% \text { of surface } \\
\text { area }\end{array}$ & $\mathrm{No}^{1}$ & $\mathrm{No}^{1}$ & $3^{1}$ \\
\hline On-farm hatching & Yes/no & $\mathrm{No}^{1}$ & $\mathrm{No}^{1}$ & $\mathrm{No}^{1}$ \\
\hline Early feeding & Yes/no & $\mathrm{No}^{1}$ & $\mathrm{No}^{1}$ & $\mathrm{No}^{1}$ \\
\hline Empty barn period & \# days & $8^{2}$ & $7^{2}$ & $7^{2}$ \\
\hline Litter type & Type & $\begin{array}{l}\text { Wood } \\
\text { shavings }^{3}\end{array}$ & Wood shavings $^{3}$ & Wood shavings $^{3}$ \\
\hline Feed composition & Type & $\begin{array}{l}\text { Concentrates }+ \\
30 \% \text { wheat }^{4}\end{array}$ & $\begin{array}{l}\text { Concentrates }+ \\
15 \% \text { wheat } \\
\text { (reduced protein } \\
\text { content relative to } \\
\text { conventional } \\
\text { feed) } 4\end{array}$ & $\begin{array}{l}\text { Min. } 70 \% \text { grain or } \\
\text { grain byproducts } \\
\text { (reduced protein } \\
\text { content relative to } \\
\text { conventional feed) }\end{array}$ \\
\hline Feeding phases & \# phases & $4^{4}$ & $4^{4}$ & $4^{4}$ \\
\hline $\begin{array}{l}\text { Manure } \\
\text { management }\end{array}$ & Type & $\begin{array}{l}\text { Disposed at end } \\
\text { of prod. cycle }\end{array}$ & $\begin{array}{l}\text { Disposed at end of } \\
\text { prod. cycle }\end{array}$ & $\begin{array}{l}\text { Disposed at end of } \\
\text { prod. cycle }\end{array}$ \\
\hline
\end{tabular}


Chapter 3

\begin{tabular}{|c|c|c|c|c|}
\hline \multirow[t]{2}{*}{ System attribute } & \multirow[t]{2}{*}{ Unit } & \multicolumn{2}{|c|}{ Production system } & \multirow[b]{2}{*}{ Extensive Indoor +} \\
\hline & & Conventional & NDRS & \\
\hline Flock size & \# broilers & $90,000^{6, b}$ & $81,035^{\mathrm{c}}$ & $54,911^{\mathrm{c}}$ \\
\hline $\begin{array}{l}\text { Veterinary } \\
\text { medicines }\end{array}$ & Type & $\begin{array}{l}\text { Antibiotics and } \\
\text { coccidiostats }{ }^{1, c}\end{array}$ & $\begin{array}{l}\text { Antibiotics and } \\
\text { coccidiostats }^{1, d}\end{array}$ & $\begin{array}{l}\text { Antibiotics and } \\
\text { coccidiostats }^{1, d}\end{array}$ \\
\hline Outdoor access & Yes/no & $\mathrm{No}^{3}$ & $\mathrm{No}^{3}$ & $\begin{array}{l}\text { Covered veranda } \\
\text { min. } 20 \% \text { of } \\
\text { surface area }\end{array}$ \\
\hline $\begin{array}{l}\text { Emission reduction } \\
\text { technique }\end{array}$ & Type & None $^{d}$ & None & None \\
\hline${ }^{1}$ Stadig (2019) & \multicolumn{4}{|c|}{${ }^{4}$ J. van Harn, personal communication, 2020} \\
\hline${ }^{2}$ Blanken et al. (2019) & & \multicolumn{3}{|c|}{${ }^{5}$ P. van Horne, personal communication, 2020} \\
\hline${ }^{3}$ Vissers et al. (2019) & & ${ }^{6}$ Gocsik et al. (201 & & \\
\hline
\end{tabular}

\subsubsection{Step 2: Identify and select external factors}

We reviewed Dutch newspapers and the scientific and semi-scientific literature for external factors related to the selected broiler production systems. The search terms included Dutch target words such as "kritiek veehouderij" (criticism livestock farming) and English target words such as "external factors poultry production". Eleven external factors were identified, shown in Table 3.2. We selected four external factors, based on the following criteria: 1) the external factor originates primarily from the broiler production system, i.e. not from other chain actors; 2 ) data is available about the external factor; and 3) the data can be linked to a broiler production system. As such, the external factors $\mathrm{AW}, \mathrm{ABU}$, ammonia $\left(\mathrm{NH}_{3}\right)$ emission and particulate matter $\left(\mathrm{PM}_{10}{ }^{\circ}\right)$ emission were selected. For external factors with multiple indicators, we selected the most widely used indicator in literature. All emissions were expressed per animal place per year and considered only at farm gate.

\footnotetext{
${ }^{\mathrm{b}}$ In line with Gocsik et al. (2016a), a flock size of 90,000 broilers was assumed in the conventional system. Based on this flock size, floor surface equaled $4,928 \mathrm{~m}^{2}$. The floor surface was assumed to be equal for all systems. Based on this floor surface, the flock size in the NDRS and Extensive Indoor+ system was calculated.

${ }^{\mathrm{c}}$ Dutch farmers must comply with strict rules on antibiotic use (Netherlands Enterprise Agency, 2020a). For instance, antibiotics may only be prescribed by veterinarians and the farmer must register all antibiotics they use.

${ }^{\mathrm{d}}$ The impact of emission reduction techniques on $\mathrm{NH}_{3}$ and $\mathrm{PM}_{10}$ emission is beyond the scope of this paper and therefore not further considered.

${ }^{\mathrm{e}} \mathrm{PM}_{10}$ is defined as 'particulate matter which passes through a size-selective inlet with a $50 \%$ efficiency cut-off at 10 m aerodynamic diameter' (Cambra-López et al., 2010).
} 
Synergies and trade-offs between externalities

Table 3.2 Overview of external factors associated with Dutch broiler production

\begin{tabular}{ll}
\hline External factor & Indicator \\
\hline Ammonia emission & $\mathrm{kg} \mathrm{NH}_{3} /$ animal place/year $^{1}$ \\
Animal health & - \\
Animal welfare & Welfare Quality index score ${ }^{2}$ \\
Antibiotic use & Defined daily doses animal ${ }^{3}$ \\
Poultry house fire & - \\
Global warming & - \\
Odor emission & - \\
Particulate matter emission & $\mathrm{g} \mathrm{PM}_{10} /$ animal place/year ${ }^{1}$ \\
Visual pollution & - \\
Water pollution & - \\
Zoonoses & \\
${ }^{1}$ Expertise Centre Infomil (2019a) & ${ }^{3}$ Van Geijlswijk et al. (2019) \\
${ }^{2}$ Welfare Quality Protocol ${ }^{\circledR}(2009)$ & - External factor is not considered in further analysis
\end{tabular}

\subsubsection{Step 3: Establish linkages}

Using a three-step procedure, linkages were established between each system attribute and the indicators of the external factors. First, the conventional system was selected as the baseline for analysis, as it contains fewest system attributes. Second, all changes in system attributes of the NDRS and Extensive Indoor+ system, relative to the conventional system, were identified from Table 3.1. Third, a yes/no indication of a linkage was established between each identified system attribute and each indicator based on a thorough literature review. The linkages are denoted by an ' $\mathrm{X}$ ' in Table 3.3. For instance, the system attribute 'stocking density'

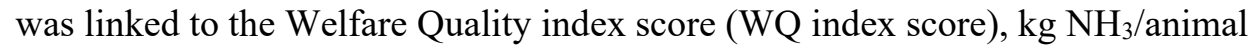
place/year and g PM10/animal place/year. The linkage with WQ index score can be explained by the positive relationship of stocking density with various diseases, such as footpad dermatitis and breast blister (Bessei, 2006). The linkage between stocking density and $\mathrm{kg} \mathrm{NH}_{3}$ /animal place/year can be explained by the positive effect of stocking density on the moisture content of the litter. A higher moisture concentration favors the production and release of ammonia (Homidan et al., 2003). The linkage between stocking density and $\mathrm{g} / \mathrm{PM}_{10} /$ animal place/year can be explained by its negative relationship with the activity of the broiler (Sørensen et al., 2000). A higher broiler activity elevates indoor $\mathrm{PM}_{10}$ concentration and emission (Calvet et al., 2009). 


\section{Chapter 3}

Table 3.3 Overview of linkages between production system attributes and indicators of external factors

\section{Indicator of external factor}

\begin{tabular}{|c|c|c|c|c|}
\hline System attribute & 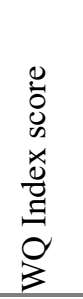 & 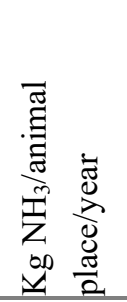 & 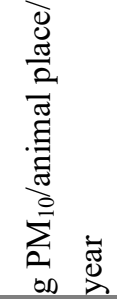 & 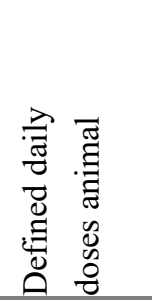 \\
\hline Broiler breed & $\mathrm{X}^{1,3}$ & $\mathrm{X}^{2}$ & $\mathrm{X}^{3,6}$ & $\mathrm{X}^{4}$ \\
\hline Length growth period & $\mathrm{X}^{5}$ & $\mathrm{X}^{2}$ & $X^{6,10}$ & \\
\hline Stocking density & $\mathrm{X}^{3,7}$ & $\mathrm{X}^{2}$ & $X^{2,6}$ & \\
\hline Straw bale enrichment & $\mathrm{X}^{8,11}$ & & $\mathrm{X}^{11,6}$ & \\
\hline Grain enrichment & $\mathrm{X}^{8,9}$ & & & \\
\hline Length dark period & $\mathrm{X}^{3,5}$ & & $\mathrm{X}^{6}$ & \\
\hline Natural light & $\mathrm{X}^{11}$ & & $X^{11,6}$ & \\
\hline Empty barn period & & $\mathrm{X}$ & $\mathrm{X}$ & \\
\hline Feed composition & $\mathrm{X}^{12}$ & $\mathrm{X}^{12}$ & $\mathrm{X}^{2}$ & \\
\hline Flock size & $X^{13}$ & & & \\
\hline Outdoor access & $\mathrm{X}^{14}$ & & & \\
\hline 'EFSA (2010) & \multicolumn{2}{|c|}{${ }^{6}$ Calvet et al. (2009) } & \multicolumn{2}{|c|}{${ }^{11}$ Bailie et al. (2013) } \\
\hline${ }^{2}$ Homidan et al. (2003) & \multicolumn{2}{|c|}{${ }^{7}$ Tullo et al. (2017) } & \multicolumn{2}{|c|}{${ }^{12}$ Van Harn et al. (2019) } \\
\hline${ }^{3}$ Bessei (2006) & \multicolumn{2}{|c|}{${ }^{8}$ Riber et al. (2018) } & \multicolumn{2}{|c|}{${ }^{13}$ Rodenburg and Koene (2007) } \\
\hline${ }^{4}$ Van Geijlswijk et al. (2019) & \multicolumn{2}{|c|}{${ }^{9}$ Waldenstedt (2006) } & \multirow{2}{*}{\multicolumn{2}{|c|}{${ }^{14}$ Stadig et al. (2017) }} \\
\hline 5 Knowles et al. (2008) & & al. (2015) & & \\
\hline
\end{tabular}

\subsubsection{Step 4: Assign weights to linkages}

We followed the procedure of Gocsik et al. (2016a) to assign weights to the linkages. To do so, the relative importance of each linkage was obtained from the scientific literature and scored on a scale of 1 to 3 , where a higher score indicates a higher relative importance. In case the literature was inconclusive, the relative importance of a linkage was estimated via Expert Knowledge Elicitation (EKE). A detailed description of the EKE procedure is provided in Appendix 3A. The relative importance scores were transformed into importance weights, such that the importance weights for each indicator sum up to one. In case the indicator is decomposed into sub-indicators, the weights sum up to one per sub-indicator (Table 3.4). These welfare measures are sub-indicators of the indicator WQ index score. Because many factors affect $\mathrm{NH}_{3}$ and $\mathrm{PM}_{10}$ emission in broiler production (e.g. humidity) (Homidan et al., 2003; Cambra-López et al., 2010), EKE indicated 


\section{Synergies and trade-offs between externalities}

that it was not possible to assign importance scores to the linkages between system attributes and $\mathrm{NH}_{3}$ and $\mathrm{PM}_{10}$ emission. Since importance scores were lacking for these linkages, it was not possible to establish weights between the system attributes and $\mathrm{NH}_{3}$ and $\mathrm{PM}_{10}$ emission.

Table 3.4 Matrix showing weights between the welfare measures and system attributes for animal welfare (obtained from Vissers et al. (2019), adapted)

\begin{tabular}{|c|c|c|c|c|c|c|c|c|c|c|c|c|}
\hline \multirow[b]{2}{*}{$\begin{array}{l}\text { System } \\
\text { attribute }\end{array}$} & \multirow[b]{2}{*}{ 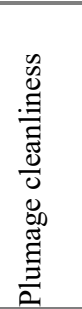 } & \multirow[b]{2}{*}{ 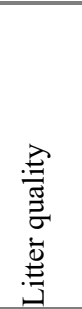 } & \multicolumn{10}{|c|}{ Welfare measures of WQ index score } \\
\hline & & & . & 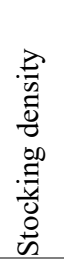 & 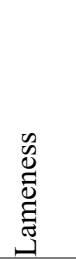 & 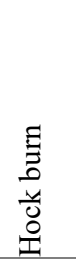 & 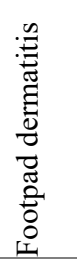 & 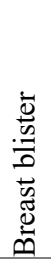 & 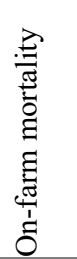 & $\cdot \frac{\mathscr{3}}{0}$ & 鸹 & 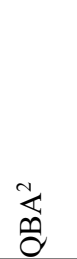 \\
\hline Broiler breed & & & 0.50 & & 0.14 & 0.25 & 0.25 & 1 & 0.50 & 0.67 & & \\
\hline $\begin{array}{l}\text { Length growth } \\
\text { period }\end{array}$ & 0.25 & 0.20 & & & 0.14 & 0.25 & 0.13 & & & & & \\
\hline Stocking density & 0.25 & 0.40 & 0.50 & 1 & 0.28 & 0.25 & & & & & & 0.14 \\
\hline $\begin{array}{l}\text { Straw bale } \\
\text { enrichment }\end{array}$ & 0.25 & & & & 0.14 & & 0.13 & & & & & 0.28 \\
\hline Grain enrichment & & & & & & & 0.13 & & & & & \\
\hline $\begin{array}{l}\text { Length dark } \\
\text { period }\end{array}$ & & 0.20 & & & 0.14 & 0.25 & 0.13 & & 0.50 & 0.33 & 0.5 & 0.28 \\
\hline $\begin{array}{l}\text { Natural light } \\
\text { Empty barn } \\
\text { period }\end{array}$ & & 0.20 & & & 0.14 & & & & & & & 0.14 \\
\hline Feed composition & & & & & & & 0.13 & & & & & \\
\hline Flock size & & & & & & & & & & & 0.5 & 0.14 \\
\hline Outdoor access & 0.25 & & & & & & 0.13 & & & & & \\
\hline $\begin{array}{l}1 \text { Avoidance Distanc } \\
\text { literature; Grey = Linl }\end{array}$ & Test; & Quali & ive $\mathrm{E}$ & avi & Ass & sment & $\begin{array}{l}\text { Whit } \\
\text { genin }\end{array}$ & & $\begin{array}{l}\text { kage } \\
\text { stock }\end{array}$ & tablis & & \\
\hline 3.2.6 Step 5: Ca & culati & nof & xtern & lfac & ors al & $d p r c$ & ductic & $1 \mathrm{co}$ & & & & \\
\hline External factors & & & & & & & & & & & & \\
\hline $\begin{array}{l}\text { The contribution } 0 \\
\text { a three-step procec } \\
\text { if applicable, per s } \\
\text { The WQ index sco } \\
\text { were obtained fror } \\
\left(D_{D D A}\right) \text { of a sys }\end{array}$ & $\begin{array}{l}\text { each } \\
\text { Ire. F } \\
\text { b-ind } \\
\text { e and } \\
\text { De J }\end{array}$ & $\begin{array}{l}\text { ysten } \\
\text { st, th } \\
\text { cator, } \\
\text { WQ s } \\
\text { ng et } \\
\text { obta }\end{array}$ & $\begin{array}{l}\text { attril } \\
\text { scor } \\
\text { was } \\
\text { ore } p \\
\text { l. }(20 \\
\text { ned } f\end{array}$ & $15)$. & $\begin{array}{l}\text { the } \\
\text { e pro } \\
\text { d fro } \\
\text { fare } 1 \\
\text { he D }\end{array}$ & $\begin{array}{l}\text { xtern } \\
\text { luctio } \\
\text { n scie } \\
\text { heasu } \\
\text { finec } \\
\text { iilsw }\end{array}$ & $\begin{array}{l}1 \text { fact } \\
\text { syst } \\
\text { itific } \\
\text { e of } t \\
\text { Daily } \\
k \text { et a }\end{array}$ & Do & $\begin{array}{l}\text { s calc } \\
\text { indi } \\
\text { nd lit } \\
\text { ducti } \\
\text { s Ani } \\
\text { 9). S }\end{array}$ & $\begin{array}{l}\text { ulatec } \\
\text { ator } \\
\text { ratur } \\
\text { n sys } \\
\text { nal }\end{array}$ & $\begin{array}{l}\text { via } \\
\text { nd, } \\
\text { ems } \\
\text { an }\end{array}$ & \\
\hline
\end{tabular}




\section{Chapter 3}

Geijlswijk et al. (2019) did not distinguish DDDAF for different systems that use slower-growing breeds, we assumed that DDDAF was similar in the NDRS and Extensive Indoor+ system. The $\mathrm{NH}_{3}$ and $\mathrm{PM}_{10}$ emission factors of the conventional system were obtained from Expertise Centre Infomil (2019a). Since these emission factors were lacking for the NDRS and Extensive Indoor+ system, they were elicited via EKE. EKE is often used to address uncertainty about parameters in large environmental models (EFSA, 2014). EKE is less suitable for precise estimations of the $\mathrm{NH}_{3}$ and $\mathrm{PM}_{10}$ emission factor of broiler production systems as they are affected by many factors (Homidan et al., 2003; Cambra-López et al., 2010). However, EKE is more suited for estimations of the relative position of systems based on their emission factors, particularly if it is carried out together with a thorough sensitivity analysis on ranking robustness. In the EKE, each expert provided individual estimates of the emission factors. The following two steps were followed to derive the distributions from the individual estimates: 1) computing the average values for the minimum, maximum and mode from the individual estimates, and then 2) deriving the PERT distribution using these average values. The PERT-fitted distributions were simulated using @risk, with 10,000 iterations.

Second, the absolute difference in score of the systems with the baseline (conventional) was calculated for each (sub-)indicator. Third, the contribution of a system attribute to an external factor was calculated by multiplying the difference in score with the weight related to that system attribute and (sub-)indicator. As weights were lacking for the linkages between the system attributes and $\mathrm{kg}$ $\mathrm{NH}_{3} /$ animal place/year and $\mathrm{g} / \mathrm{PM}_{10} /$ animal place/year emission (see step 4 ), the contribution of the system attributes to these external factors could not be calculated. Instead, EKE was carried out to obtain qualitative estimations of the contribution of the system attribute to these external factors (see Appendix $3 \mathrm{~A}$ for detailed procedure).

\section{Production costs}

The production costs were calculated for each production system using the deterministic model of Gocsik et al. (2016a). Input prices and production performance indicators were obtained from Blanken et al. (2019) and can be found in Appendix 3B. As delivery weight was similar for all systems $(2,380 \mathrm{~g})$, no corrections had to be made for the emission factors and production costs per delivered broiler. Production costs were expressed per delivered broiler and were assigned to system attributes. Most production cost components were linked to a 
single attribute (e.g. day-old-chick costs to broiler breed). However, cost components related to the technical performance indicators 'feed conversion rate' (feed costs), 'mortality rate' (mortality costs) and 'daily weight gain' (housing costs) were linked to multiple attributes. They were assigned to system attributes using weights between the attributes and the technical performance indicators that were obtained from literature (as done for the external factors in step 3 and 4). These weights are provided in Appendix 3C. The income earned from the production systems was indicated by the net return to labor and management (total revenues minus total costs excluding labor costs). The production costs, net return to labor and management and external factors were expressed both per animal and per farm level.

\section{Sensitivity analysis}

A sensitivity analysis was carried out to test the impact of price fluctuations and uncertainty with respect to the estimated emission factors on the robustness of the results. The impact of price fluctuations on net return to labor and management was tested by using different feed price levels. Feed price was selected as these prices are subject to considerable fluctuations and feed costs are the main cost component in broiler production (Gocsik et al., 2016a). In this respect, two cases were analyzed for the period 2015-2019, i.e. a best-case and a worst-case scenario. The best-case scenario uses the minimum feed price and the worst-case scenario the maximum feed price. The impact of uncertainty with respect to the estimated emission factors was tested by using the average maximum value and average minimum value from the individual estimates as best and worst case scenarios, respectively.

\subsection{Results and discussion}

\subsubsection{Synergy and trade-offs per animal}

The effects of changes in system attributes on external factors were analyzed to identify the synergies and trade-offs caused by these changes. In this analysis, the external factors $\mathrm{NH}_{3}$ emission and $\mathrm{PM}_{10}$ emission were expressed per animal place per year. Insight in the synergies and trade-offs was used to assess the potential for mitigating multiple external factors in broiler production systems. Table 3.5 and Table 3.6 show the effects of changes in system attributes on the external factors and production costs in the NDRS and Extensive Indoor+ systems relative to the conventional system. Overall, these changes in system attributes improve AW and lower ABU. On the other hand, these changes elevate $\mathrm{NH}_{3}$ and $\mathrm{PM}_{10}$ emissions per animal place per year, and increase the production costs per animal. The reduction 


\section{Chapter 3}

of ABU can be explained by the synergy that was generated by 'broiler breed' (+WQ index score, - DDDA $_{\mathrm{F}}$ ). A slower-growing breed is less susceptible to diseases such as lameness and hock burn (Kjaer et al., 2006; EFSA, 2010). Welfare improvements, such as a slower-growing breed, can reduce ABU through reduced stress-induced immunosuppression and a reduced incidence of diseases (De Passillé \& Rushen, 2005; Dawkins, 2017). Our results are in line with BokmaBakker et al. (2017), who found that the use of a slower-growing breed was one of the main factors for reduced ABU in the NDRS and Extensive Indoor+ system relative to the conventional system. However, the reduction of ABU in their study was not only caused by the different broiler breed, but also by other factors such as differences in the quality of the day old chicks and farmer's perception towards antibiotics (Bokma-Bakker et al., 2017).

The results in Table 3.5 and Table 3.6 also provide evidence of several synergies and trade-offs. Synergy between $\mathrm{AW}$ and $\mathrm{NH}_{3}$ emission is found in the NDRS and Extensive Indoor+ systems; this synergy is attributable to changes in the system attributes 'feed composition' (+WQ index score, $-\mathrm{kg} \mathrm{NH}_{3} /$ animal place/year) and possibly 'stocking density' (+WQ index score, $-/ 0 /+\mathrm{kg} \mathrm{NH}_{3} /$ animal place/year). The synergy caused by 'feed composition' can be explained by the lower protein content of the diet, which reduces the nitrogen excretion and $\mathrm{NH}_{3}$ emission from broiler houses (Namroud et al., 2008; Van Harn et al., 2019). In addition, a study by Van Harn et al. (2019) showed that a lower crude protein in the diet improves litter quality and thereby reduces the risk of foot pad dermatitis. It should be noted that slower-growing broilers are less susceptible to foot pad dermatitis relative to fast-growing broilers (Kjaer et al., 2006; EFSA, 2010). Therefore, the contribution of a reduced protein content in feed to reduced risk of foot pad dermatitis is most likely small for slower-growing broilers. A lower stocking density enhances AW by reducing the risk of health problems such as panting and lameness (Sørensen et al., 2000; EFSA, 2010). In addition, a reduced stocking density may lower $\mathrm{NH}_{3}$ emission, although this depends on the magnitude of two opposite effects. On the one hand, a reduced stocking density enlarges the emitting area of the broiler. On the other hand, a (substantial) reduction of the stocking density may enhance the dry matter content of the litter (Sørensen et al., 2000). According to Groot Koerkamp et al. (2000), a dry matter content below $60 \%$ or above $80 \%$ mitigates the formation of $\mathrm{NH}_{3}$ from litter. Currently, there is no scientific evidence on the magnitude of both effects when lowering the stocking density. The synergy caused by 'feed composition' and possibly also 'stocking density' indicate that 
improvements in $\mathrm{AW}$ do not necessarily increase $\mathrm{NH}_{3}$ emission per se, because these attributes do not deteriorate or improve the litter quality. This finding is in line with Leinonen et al. (2014), who found that alternative systems that enhance bird welfare can have the same or a lower acidification potential compared to a conventional system, at least when the feed conversion ratio is not significantly increased.

In the NDRS and Extensive Indoor+ system, most changes in system attributes caused a trade-off between AW and $\mathrm{PM}_{10}$ emission. This trade-off can be explained by the positive effect of these changes on broiler activity. A higher broiler activity improves the leg health of broilers (Bessei, 2006; Bailie et al., 2013). On the other hand, a higher activity increases dust production, causing higher $\mathrm{PM}_{10}$ concentrations and emission rates (Calvet et al., 2009; Peña Fernández et al., 2019). As broilers are more active at the end of the growing cycle, the contribution of broiler activity to $\mathrm{PM}_{10}$ concentrations plays a more important role at the end of the growing cycle than at the beginning of the cycle (Peña Fernández et al., 2019). Next to broiler activity, other factors such as ventilation rates play a major role in PM concentrations and emissions (Cambra-López et al., 2010). A higher ventilation rate dilutes indoor $\mathrm{PM}_{10}$ concentration, gradually decreasing the level of indoor $\mathrm{PM}_{10}$ concentration (Peña Fernández et al., 2019). However, increased ventilation rates may result in increased PM emissions (Cambra-López et al., 2010). 
Chapter 3

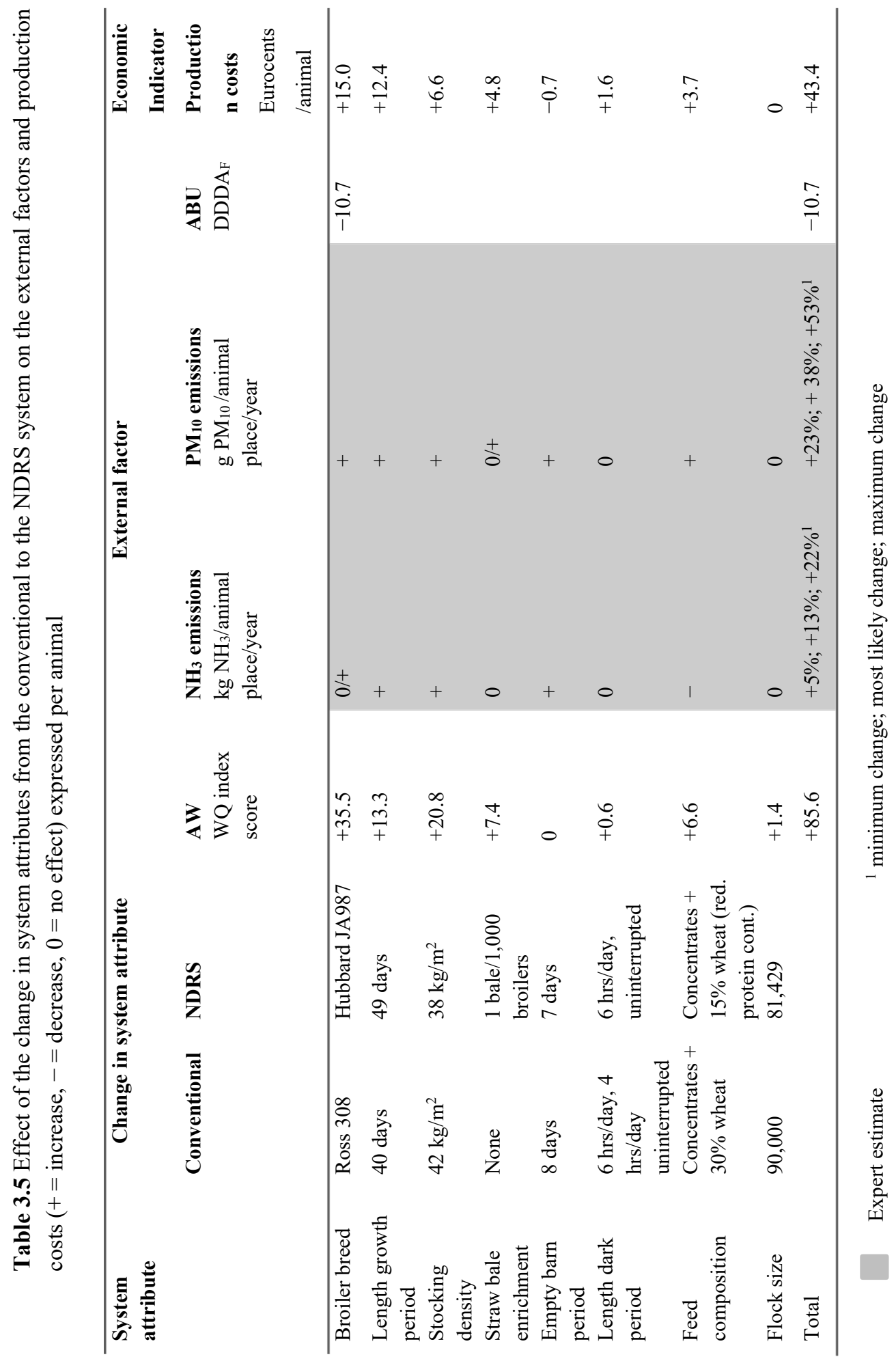


Synergies and trade-offs between externalities

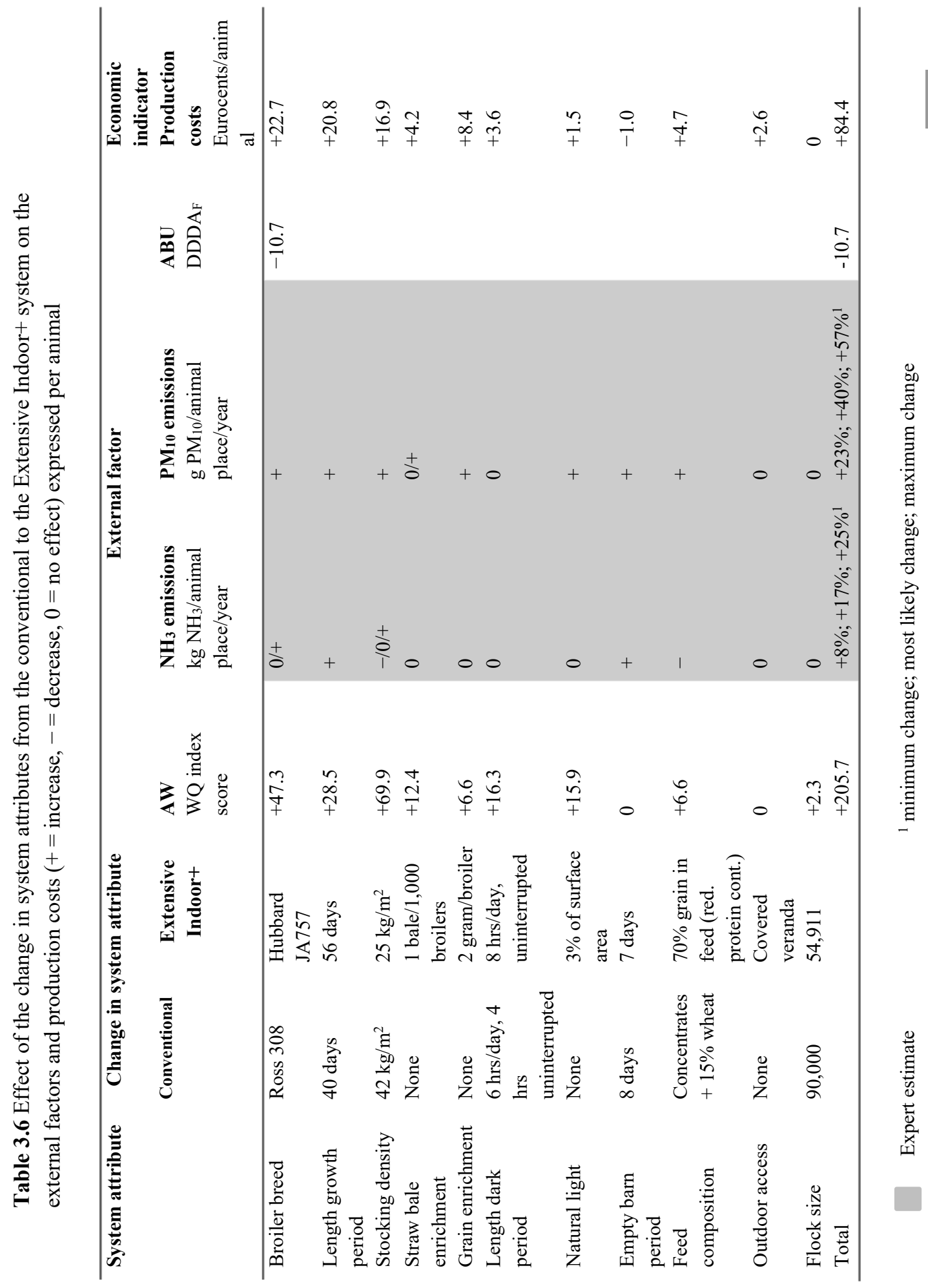




\section{Chapter 3}

To obtain insight in the cost-efficiency of the system attributes, the impact of the attributes on production costs and external factors were analyzed simultaneously. Figure 3.2 shows the cost-efficiency of the system attributes in terms of the change in AW per percentage increase in production costs (X-axis) and their corresponding effect on the emission of $\mathrm{NH}_{3}$ and $\mathrm{PM}_{10}$ per animal place per year (Y-axis). These effects are ranked from 'no effect on $\mathrm{NH}_{3}$ and $\mathrm{PM}_{10}$ emission' to 'a positive effect on $\mathrm{NH}_{3}$ and $\mathrm{PM}_{10}$ emission'. The figure shows that the system attributes 'outdoor access', 'flock size' and 'empty barn period' were the least costefficient in terms of AW. The attributes 'natural light', and to a lesser extent 'length of dark period', were the most cost-efficient in terms of AW. Both attributes did not affect $\mathrm{NH}_{3}$ emission, and only 'natural light' elevated $\mathrm{PM}_{10}$ emission. Hence, 'length dark period' was the only system attribute that was costefficient in terms of $\mathrm{AW}$ and did not evoke trade-offs on $\mathrm{NH}_{3}$ and $\mathrm{PM}_{10}$ emission.

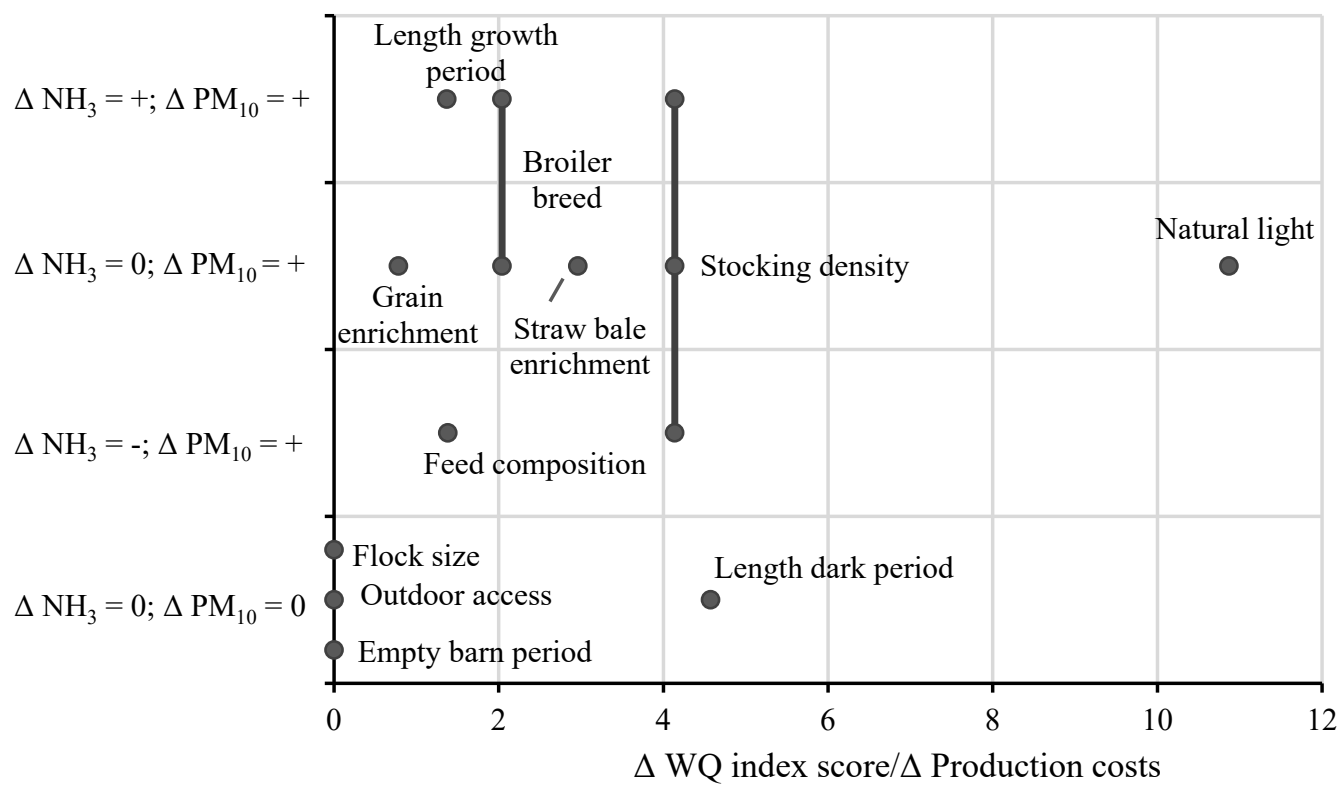

$\Delta \mathrm{NH}_{3}=\Delta \mathrm{kg} \mathrm{NH}_{3} /$ animal place/year, $\Delta \mathrm{PM}_{10}=\Delta \mathrm{g} \mathrm{PM} 10 /$ animal place/year

Figure 3.2 Cost-efficiency of system attributes in the Extensive Indoor+ system relative to the conventional system

\subsubsection{Synergy and trade-offs at farm level}

For each system, $\mathrm{NH}_{3}$ emission, $\mathrm{PM}_{10}$ emission and the net return to labor and management originating at farm level was calculated and expressed per farm per year. The $\mathrm{NH}_{3}$ and $\mathrm{PM}_{10}$ emission was calculated at farm level to assess whether 
the shift from conventional system towards the NDRS or Extensive Indoor+ system caused a synergy or a trade-off on $\mathrm{NH}_{3}$ and $\mathrm{PM}_{10}$ emissions. Table 3.7 shows the net return to labor and management and the external factors originating from the systems at farm level. The $\mathrm{NH}_{3}$ and $\mathrm{PM}_{10}$ emitted per farm per year was lowest in the Extensive Indoor+ system, followed by the conventional and NDRS system. This ranking can be explained by the differences in the emission per animal place and stocking density. Since we assumed floor surface to be fixed, a lower stocking density implies less broilers reared in the poultry house. When comparing the NDRS system with the conventional system, the higher emission per animal place per year offsets the lower number of broilers reared at the farm (approx. 81,500 broilers per round vs. 90,000 broilers per round). When comparing the Extensive Indoor+ system with the conventional system, results suggest that the higher emission per animal place per year is offset by the decrease in emission that is caused by the reduced number of broilers at the farm (approx. 55,000 broilers per round vs 90,000 broilers per round). Hence, elevated emissions per animal place, e.g. caused by a longer growth period, can be partly or fully compensated at farm level via a reduction of the stocking density. It should be taken into account that these results are partially obtained from expert estimation, and further research is required for final confirmation.

The results indicate that the highest net return to labor and management was earned in the Extensive Indoor+ system, followed by the NDRS and conventional system. These findings are in line with the findings of Van Horne (2020a). The ranking is caused by the additional price premium farmers receive in the NDRS and Extensive Indoor+ system, which outweighs the higher production costs per animal and the reduction in broiler production per year. Gocsik et al. (2013) and Gocsik et al. (2015) underline the importance of price premiums for the long run profitability of alternative broiler production systems. Gocsik et al. (2013) show that the alternative Dutch broiler production systems were more economically feasible than the conventional system, provided that the price premium was received in the alternative system. However, in case of a 50\% lower price premium the alternative systems performed worse than the conventional system in terms of economic feasibility. Given the uncertainty that may be associated with the level of the price premium, the alternative systems may lead to a higher income risk for farmers (Gocsik et al., 2015). 


\section{Chapter 3}

Table 3.7 External factors and net return to labor and management generated from the production systems expressed per farm per year (based on 4,928 $\mathrm{m}^{2}$ floor space)

\begin{tabular}{|c|c|c|c|c|c|c|c|}
\hline \multirow[b]{2}{*}{ System } & \multicolumn{4}{|c|}{ External factor } & \multicolumn{3}{|c|}{ Economic indicator } \\
\hline & $\begin{array}{l}\text { AW } \\
\text { WQ } \\
\text { index } \\
\text { score }\end{array}$ & $\begin{array}{l}\mathbf{N H}_{3} \\
\text { emission } \\
\mathrm{Kg} \mathrm{NH}_{3} / \\
\text { farm/yr }\end{array}$ & $\begin{array}{l}\mathbf{P M}_{10} \\
\text { emission } \\
\mathrm{Kg} \mathrm{PM}_{10} / \\
\text { farm/yr }\end{array}$ & $\begin{array}{l}\mathbf{A B U} \\
\mathrm{DDDA}_{\mathrm{F}}\end{array}$ & $\begin{array}{l}\text { Producti } \\
\text { on costs } \\
\text { Thousand } \\
€ / \text { farm } / y r\end{array}$ & $\begin{array}{l}\text { Revenues } \\
\text { Thousand } \\
€ / \text { farm/yr }\end{array}$ & $\begin{array}{l}\text { Net return } \\
\text { to lab. \& } \\
\text { man. } \\
\text { Thousand } \\
€ / \text { farm/yr }\end{array}$ \\
\hline Conventional & 593.1 & $6,120^{1}$ & $1,980^{1}$ & 14.3 & $1,513.7$ & $1,571.6$ & 36.7 \\
\hline NDRS & 678.7 & $6,275^{2}$ & $2,478^{2}$ & 3.6 & $1,224.4$ & $1,287.4$ & 40.1 \\
\hline $\begin{array}{l}\text { Extensive } \\
\text { Indoor+ }\end{array}$ & 798.8 & $4,356^{2}$ & $1,691^{2}$ & 3.6 & 962.1 & $1,026.7$ & 48.9 \\
\hline
\end{tabular}

\subsubsection{Sensitivity analysis}

A sensitivity analysis was carried out to study the effect of price fluctuations and data uncertainties on the robustness of the results. Figure 3.3 shows that the net return to labor and management ranged between 6.9 K EUR (worst case) and 88.7 K EUR (best case) in the conventional system. In the Extensive Indoor+ system, net return to labor and management ranged between 16.3 and 81.8, and between 28.4 and 78.1 K EUR, respectively. Results indicate that for the NDRS and Extensive Indoor+ system, the net return to labor and management is less sensitive to feed price fluctuations, compared to the conventional system. This finding can be explained by the lower amount of feed required in the NDRS and Extensive Indoor+ system compared to the conventional system. In this regard, two opposite forces occur: a higher feed conversion rate of the broiler (more feed per animal) and a lower stocking density (less feed per $\mathrm{m}^{2}$ ) (Blanken et al., 2019). Verspecht et al. (2011) indicate that the impact of feed price fluctuations on farm profits might be less negative at lower stocking densities. The lower sensitivity of the NDRS and Extensive Indoor+ system to feed price fluctuations is reflected in the ranking of these systems. In the worst case scenario, net return to labor and management was highest in the Extensive Indoor+ system and lowest in the conventional system. In contrast, in the best case scenario, net return to labor and management was highest in the conventional system and lowest in the Extensive Indoor+ system. 
Synergies and trade-offs between externalities
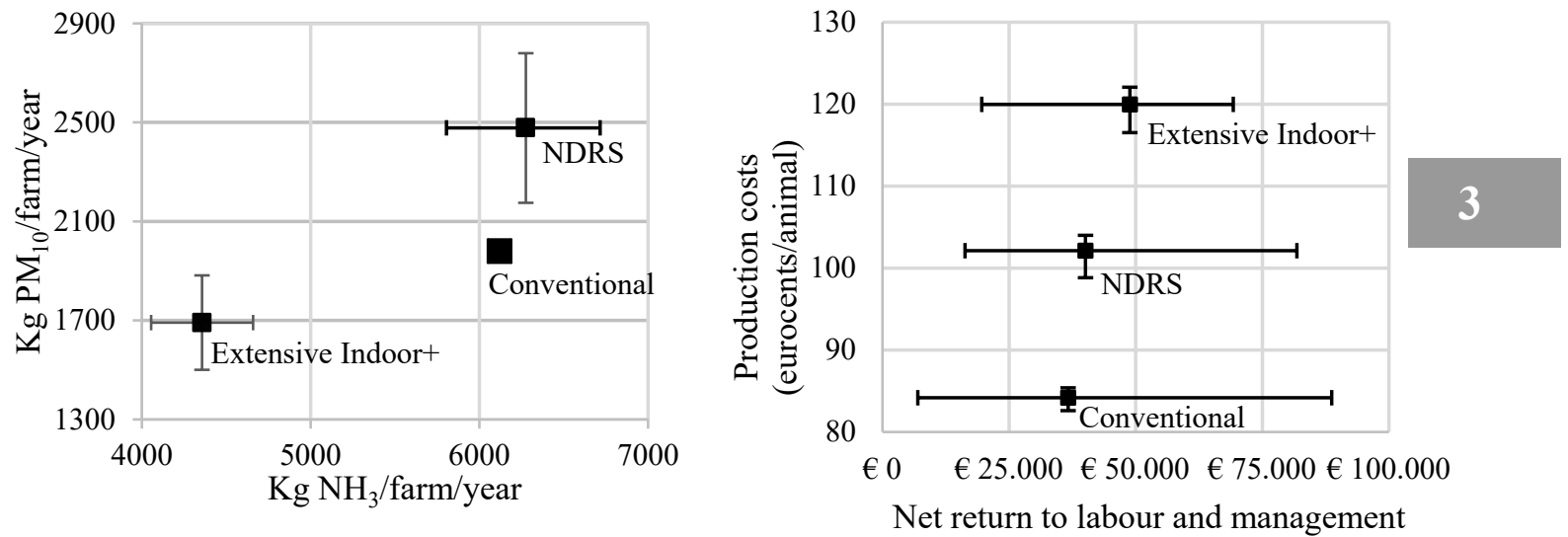

(farm/year)

Figure 3.3 Sensitivity analysis results on $\mathrm{kg} \mathrm{NH}_{3}$ and $\mathrm{PM}_{10}$ emitted from the production systems expressed per farm per year and net return to labor and management expressed per year (based on 4,928 $\mathrm{m}^{2}$ floor space)

\subsection{Policy implications and outlook}

The European Commission (2020) set up the Farm to Fork Strategy to accelerate the transition towards more sustainable food systems. This strategy includes goals such as a reduction in nutrient losses (especially nitrogen and phosphorus) and a reduction in the sales of antimicrobials for farmed animals and in aquaculture by $50 \%$ in 2030. Our study provides valuable insights that support policy making in the development of systems that coincide with these goals. First, our findings suggest that there is a scope for designing optimal broiler production systems by selecting system attributes based on their cost-efficiency in terms of AW and their impact on $\mathrm{ABU}, \mathrm{NH}_{3}$ and $\mathrm{PM}_{10}$ emission. Using this approach, multiple external factors can be mitigated at a minimum increase in production costs and the price premium required for its introduction. Second, our study showed that most changes in system attributes that enhanced $\mathrm{AW}$ had a trade-off in terms of $\mathrm{NH}_{3}$ and $\mathrm{PM}_{10}$ emission per animal place per year. However, these effects were partly (NDRS) or fully (Extensive Indoor+) offset at farm level via a lower stocking density. This insight is particularly relevant because a major shift towards more extensive broiler production systems is projected to occur in the EU in 2026. In 2026, over 100 leading food companies across Europe will adopt the AW standards of the Better Chicken Commitment (2020). Third, our study showed that the changes in system attributes in the NDRS and Extensive Indoor+ system enhanced production costs per animal and lowered the output of broilers relative to the conventional system. Broiler farmers switching to towards the NDRS or Extensive Indoor+ system could 


\section{Chapter 3}

maintain or even improve their income due to the price premiums associated with their products. Whereas the price premiums resulted in a higher consumer price, in case of the NDRS, the price increase did not lower consumer welfare as it was offset by the increase in consumer valuation of the product (Vissers et al., 2021a). The lower output of broilers can be explained by the longer growth period of the broiler and the lower stocking density in the NDRS and Extensive Indoor+ system relative to the conventional system. Implementation of measures that lower total annual output of broilers might harm the profitability of the processing industry if not combined with a price premium or an expansion of broiler production capacity.

\subsection{Conclusions}

The findings from this paper indicate that improvements in AW may cause a synergy with $\mathrm{ABU}$ and do not necessarily cause a trade-off with $\mathrm{NH}_{3}$ emission. Nearly all AW improvements caused a trade-off with $\mathrm{PM}_{10}$ emission. Findings also indicate that the cost-efficiency of the system attributes in terms of AW and their corresponding effect on the emission of $\mathrm{NH}_{3}$ and $\mathrm{PM}_{10}$ per animal place per year differed among system attributes. Based on these findings, we conclude that the development of broiler production systems can exploit the synergy between AW, $\mathrm{ABU}$ and $\mathrm{NH}_{3}$ emission and minimize the trade-off between $\mathrm{AW}$ and $\mathrm{PM}_{10}$ emission. The insights obtained from this paper can serve as a basis for future research that explores the potential of future broiler production systems minimizing external factors originating from broiler production systems. We suggest that future research applies this approach to other livestock production systems to expose the synergy and trade-offs caused by these systems and the potential for optimization of these livestock production systems.

\section{Acknowledgements}

This work was financially supported by the Food Pro-tec-ts project. This project is carried out within the framework of the INTERREG V A program "DeutschlandNederland" and is co-financed by the European Regional Development Fund (ERDF) and the Dutch Ministry of Economic Affairs and Climate Change, the Ministry of Economic Affairs, Innovation, Digitalization and Energy of North Rhine-Westphalia and the provinces of Gelderland, Limburg and North Brabant. It is accompanied by the program management at the Euregio Rhein-Waal. We gratefully acknowledge I.C. de Jong, H. Gunnink and V.A. Hindle for providing the dataset on broiler welfare. Furthermore, we gratefully acknowledge the experts for participating in the expert knowledge elicitation. 


\section{Appendix}

\section{Appendix 3A. Selection of experts}

The following criteria were considered when selecting experts to estimate the $\mathrm{NH}_{3}$ and $\mathrm{PM}_{10}$ emission factors of the NDRS and Extensive Indoor+ systems:

- Substantive knowledge regarding broiler welfare, ammonia emissions or particulate matter emissions originating from broiler production systems

- Substantive knowledge about the Dutch broiler sector

Based on these criteria, the following experts were consulted:

- Jan van Harn, researcher at Wageningen Livestock Research. Jan van Harn is expert in poultry nutrition.

- Hilko Ellen, researcher at Wageningen Livestock Research. Hilko Ellen is expert in poultry housing and agricultural engineering.

- Albert Winkel, researcher Wageningen Livestock Research. Albert Winkel is expert in particulate matter and poultry housing.

- Rick van Emous, researcher Wageningen Livestock Research. Rick van Emous is expert in poultry nutrition.

- Peter Groot Koerkamp, professor at the farm technology group, Wageningen University. Peter Groot Koerkamp is expert in agricultural engineering and poultry farming.

- Ingrid de Jong, researcher at Wageningen Livestock Research. Ingrid is expert in poultry welfare.

\section{Interviews}

The EKE was conducted using the Sheffield method. Before the interviews, the experts were provided with background information and the scope of the EKE. The elicitation was conducted in the following two steps.

Step 1: one-on-one interview. Each expert was asked to qualitative estimate the effect $(-/ 0 /+)$ of each change in system attribute of the NDRS system, relative to the conventional system, on the $\mathrm{NH}_{3}$ emission factor. Consequently, after all changes in system attributes of the NDRS system were asked, the expert was asked to quantitatively estimate the aggregated effect of the changes in system attributes on the $\mathrm{NH}_{3}$ emission factor. The experts were asked to provide a minimum, maximum, and most likely value. A similar procedure was conducted for estimations of the $\mathrm{PM}_{10}$ emission factor in the NDRS system, and $\mathrm{NH}_{3}$ and $\mathrm{PM}_{10}$ emission factor in the Extensive Indoor+ system. The quantitative estimations are provided in Tables $\mathrm{B} 1$ and $\mathrm{C} 1$. 


\section{Chapter 3}

Step 2: joint interview. The experts were asked to discuss their individual estimates and then to reach consensus on a group estimate. Since the experts did not achieve consensus on a group estimate, the average of the individual estimates were used in the analysis.

Appendix 3B. Main technical performance indicators and prices

Table B1 Overview of main technical performance indicators and prices of the selected systems

\begin{tabular}{llll}
\hline Indicator & Conventional & NDRS & Extensive Indoor+ \\
\hline Feed conversion ratio $(\mathrm{g} / \mathrm{g})$ & $1.6^{1}$ & $1.9^{1}$ & $2.1^{1}$ \\
Mortality rate $(\%)$ & $3.5^{1}$ & $3.0^{1}$ & $2.5^{1}$ \\
Daily weight gain (g/day) & $60.0^{1}$ & $49.0^{1}$ & $42.5^{1}$ \\
$\begin{array}{l}\text { Day-old-chick price } \\
\text { (eurocents } / \text { broiler) }\end{array}$ & $33.0^{1}$ & $35.5^{1}$ & $35.5^{1}$ \\
Feed price $\mathrm{P}_{0}(€ / 100 \mathrm{~kg})$ & $31.3^{1}$ & & \\
$\begin{array}{l}\text { Producer price } \mathrm{P}_{0} \\
\text { (eurocents/kg) }\end{array}$ & $82.0^{1}$ & $31.8^{1}$ & $31.8^{1}$ \\
${ }^{1}$ Blanken et al. $(2019)$ & $100.0^{1}$ & $115.0^{1}$ \\
& \multicolumn{3}{c}{ Gocsik et al. (2013) }
\end{tabular}

Appendix 3C. Weights assigned to linkages between system attributes and production performance indicators

Table C1 Weights assigned to linkages between system attributes and technical performance indicators

\begin{tabular}{|c|c|c|c|}
\hline \multirow[t]{2}{*}{ Attribute } & \multicolumn{3}{|c|}{ Performance indicator } \\
\hline & $\begin{array}{l}\text { Feed conversion rate } \\
(\mathrm{g} / \mathrm{g})\end{array}$ & $\begin{array}{l}\text { Daily weight gain } \\
\text { (g/day) }\end{array}$ & Mortality (\%) \\
\hline Broiler breed & $0.33^{1}$ & $0.33^{1}$ & $0.33^{2}$ \\
\hline $\begin{array}{l}\text { Length growth } \\
\text { period }\end{array}$ & $0.33^{2}$ & $0.33^{2}$ & 0 \\
\hline Stocking density & 0 & $0.17^{3}$ & 0 \\
\hline $\begin{array}{l}\text { Straw bale } \\
\text { enrichment }\end{array}$ & 0 & 0 & 0 \\
\hline Grain enrichment & 0 & 0 & 0 \\
\hline Length dark period & $0.17^{4}$ & $0.17^{4}$ & $0.33^{4}$ \\
\hline Natural light & 0 & 0 & 0 \\
\hline Empty barn period & 0 & 0 & 0 \\
\hline Feed composition & $0.17^{5}$ & 0 & 0 \\
\hline Flock size & 0 & 0 & 0 \\
\hline Outdoor access & 0 & 0 & $0.33^{6}$ \\
\hline Blanken et al. (2019) & ${ }^{4}$ Knowles e & (2008) & \\
\hline EFSA Panel (2010) & ${ }^{5}$ Van Harn et & (2019) & \\
\hline Sørensen et al. (2000) & ${ }^{6}$ Mikulski et & $(2011)$ & \\
\hline
\end{tabular}




\section{References}

Agrimatie. (2015). Voorzieningsbalansen. Retrieved from https://www.agrimatie.nl/VoorzieningsBalansen.aspx

Agrimatie. (2018). Agrarische prijzen. Retrieved from https://www.agrimatie.nl/Prijzen.aspx?ID=15125

Albert Heijn. (2018). AH hele kip. Retrieved from https://www.ah.nl/producten/product/wi39978/ah-hele-kip

Bailie, C. L., Ball, M. E. E., \& O'Connell, N. E. (2013). Influence of the provision of natural light and straw bales on activity levels and leg health in commercial broiler chickens. Animal, 7(4), 618-626. doi:https://doi.org/10.1017/S1751731112002108

Baumol, W. J., Panzar, J., \& Willig, R. (1983). Contestable markets: an uprising in the theory of industry structure. American Economic Review, 73(3), 491496. doi:www.jstor.org/stable/1808145

Bessei, W. (2006). Welfare of broilers: a review. World's Poultry Science Journal, 62(3), 455-466. doi:https://doi.org/10.1017/S0043933906001085

Better Chicken Commitment. (2020). Better Chicken Commitment. Retrieved from https://betterchickencommitment.com/

Blanken, K., De Buisonje, F., Evers, A. G., Ouweltjes, W., Verkaik, J. C., Vermeij, I., \& Wemmenhove, H. (2019). KWIN 2019-2020: Wageningen University $\&$ Research.

Bokkers, E. A. M., \& De Boer, I. J. M. (2009). Economic, ecological, and social performance of conventional and organic broiler production in the Netherlands. British Poultry Science, 50(5), 546-557. doi:https://doi.org/10.1080/00071660903140999

Bokma-Bakker, M. H., Wiegel, J., Holstege, M. M. C., Kluivers-Poodt, M., De Lauwere, C. C., \& Bouwstra, R. J. (2017). Onderzoek naar kritische succesfactoren voor een laag antibioticumgebruik bij vleeskuikens: rapport van het project Kritische Succesfactoren Pluimvee (KSF Pluimvee). In Livestock Research rapport, 1570-8616 ; 1065A. Retrieved from https://doi.org/10.18174/427330

Bracke, M. B. M., Koene, P., Estevéz, I., Butterworth, A., \& de Jong, I. C. (2019). Broiler welfare trade-off: A semi-quantitative welfare assessment for optimised welfare improvement based on an expert survey. PLoS One, 14(10), e0222955. doi:https://doi.org/10.1371/journal.pone.0222955

Broom, D. M. (2017). Animal Welfare in the European Union. Retrieved from http://www.europarl.europa.eu/RegData/etudes/STUD/2017/583114/IPOL STU(2017)583114 EN.pdf

Calvet, S., Van den Weghe, H., Kosch, R., \& Estellés, F. (2009). The influence of the lighting program on broiler activity and dust production. Poultry Science, 88(12), 2504-2511. doi:https://doi.org/10.3382/ps.2009-00255

Cambra-López, M., Aarnink, A. J. A., Zhao, Y., Calvet, S., \& Torres, A. G. (2010). Airborne particulate matter from livestock production systems: A review 


\section{Chapter 3}

of an air pollution problem. Environmental Pollution, 158(1), 1-17. doi:https://doi.org/10.1016/j.envpol.2009.07.011

CBS. (2018). Consumentenprijsindex; 2015=100. Retrieved from: http://statline.cbs.nl/Statweb/publication/?DM=SLNL\&PA=83131NED\& $\mathrm{D} 1=4 \& \mathrm{D} 2=12 \& \mathrm{D} 3=220 \% 2 \mathrm{c} 233 \% 2 \mathrm{c} 246 \% 2 \mathrm{c} 259 \% 2 \mathrm{c} 272 \% 2 \mathrm{c} 285 \& \mathrm{HDR}=$ $\mathrm{T} \& \mathrm{STB}=\mathrm{G} 2 \% 2 \mathrm{cG} 1 \& \mathrm{VW}=\mathrm{T}$

Dawkins, M. S. (2017). Animal welfare and efficient farming: is conflict inevitable? Animal Production Science, 57(2), 201-208. doi:https://doi.org/10.1071/AN15383

De Jong, I. C., Gunnink, H., \& Hindle, V. A. (2015). Implementation of the Welfare Quality broiler assessment protocol-final report: overview of outcome-based measurement of broiler welfare and a general discussion on the Welfare Quality broiler assessment protocol. Retrieved from https://library.wur.n1/WebQuery/wurpubs/486781

De Jonge, J., \& Van Trijp, H. C. M. (2013). Meeting heterogeneity in consumer demand for animal welfare: A reflection on existing knowledge and implications for the meat sector. Journal of Agricultural and

Environmental Ethics, 26(3), 629-661. doi:https://doi.org/10.1007/s10806012-9426-7

De Passillé, A. M., \& Rushen, J. (2005). Food safety and environmental issues in animal welfare. Revue scientifique et technique-Office international des épizooties, 24(2), 757.

Dutch Ministry of Infrastructure and Water Management. (2020). Kengetallen Leefomgeving. Retrieved from https://www.rwseconomie.nl/kengetallen/kengetallen-leefomgeving.

EFSA. (2010). Scientific Opinion on the influence of genetic parameters on the welfare and the resistance to stress of commercial broilers. EFSA Journal, 8(7), 1666. doi:https://doi.org/10.2903/j.efsa.2010.1666

EFSA. (2014). Guidance on Expert Knowledge Elicitation in Food and Feed Safety Risk Assessment. EFSA Journal, 12(6), 278. doi:https://doi.org/10.2903/j.efsa.2014.3734

Eurobarometer. (2015). Attitudes of Europeans towards biodiversity. Retrieved from https://op.europa.eu/nl/publication-detail/-/publication/50bfl efd720b-11e9-9f05-01aa75ed71a1/language-en/format-PDF

Eurobarometer. (2016). Attitudes of Europeans towards animal welfare. Retrieved from https://ec.europa.eu/commfrontoffice/publicopinion/index.cfm/ResultDoc/ download/DocumentKy/71348

Eurobarometer. (2017). Attitudes of European citizens towards the environment. Retrieved from https://ec.europa.eu/public opinion/archives/ebs/ebs 416 en.pdf.

Eurobarometer. (2019). Food Safety in the EU. European Commission Retrieved from 
Synergies and trade-offs between externalities

https://www.efsa.europa.eu/sites/default/files/corporate publications/files/ Eurobarometer2019 Food-safety-in-the-EU Full-report.pdf.

European Commission. (2020). Farm to Fork Strategy. Retrieved from https://ec.europa.eu/food/sites/food/files/safety/docs/f2f actionplan 2020 strategy-info en.pdf

European Council Directive. Directive 2001/81/EC of the European Parliament and of the council of 23 October 2001 on national emission ceilings or certain atmospheric pollutants, (2001).

European Council Directive. Directive 2003/99/EC of the European Parliament and of the Council of 17 November 2003 on the monitoring of zoonoses and zoonotic agents, (2003).

European Council Directive. Directive 2007/43/EC of 28 June 2007 laying down minimum rules for the protection of chickens kept for meat production, 2007/43/EC C.F.R. (2007).

European Council Directive. Directive 2008/120/EC of 18 December 2008 laying down minimum standards for the protection of pigs, (2008).

European Council Directive. Regulation (EC) No 1069/2009 of the European Parliament and of the Council of 21 October 2009 laying down health rules as regards animal by-products and derived products not intended for human consumption and repealing Regulation (EC), 1069/2009 C.F.R. (2009).

European Council Directive. Directive 2016/2284 of the European Parliament and of the Council of 14 December 2016 on the reduction of national emissions of certain atmospheric pollutants, 2016/2284 C.F.R. (2016).

Expertise Centre Infomil. (2019). Emission factors per animal - broilers. Retrieved from

https://www.infomil.nl/onderwerpen/landbouw/stalsystemen/emissiefactor en-per/map-staltypen/5-diercategorie/

FAPRI. (2019). FAPRI Elasticity Database. Retrieved from: http://www.fapri.iastate.edu/tools/elasticity.aspx

Gallet, C. A. (2010). Meat meets meta: a quantitative review of the price elasticity of meat. American Journal of Agricultural Economics, 92(1), 258-272. doi:https://doi.org/10.1093/ajae/aap008

Gocsik, É., Brooshooft, S. D., De Jong, I. C., \& Saatkamp, H. W. (2016). Costefficiency of animal welfare in broiler production systems: A pilot study using the Welfare Quality ${ }^{\circledR}$ assessment protocol. Agricultural Systems, 146, 55-69. doi:https://doi.org/10.1016/j.agsy.2016.04.001

Gocsik, É., Oude Lansink, A. G. J. M., \& Saatkamp, H. W. (2013). Mid-term financial impact of animal welfare improvements in Dutch broiler production. Poultry Science, 92(12), 3314-3329. doi:https://doi.org/10.3382/ps.2013-03221

Gocsik, É., Van der Lans, I. A., Oude Lansink, A. G. J. M., \& Saatkamp, H. W. (2015). Willingness of Dutch broiler and pig farmers to convert to 
Chapter 3

production systems with improved welfare. Animal Welfare, 24(2), 211-

222. doi:https://doi.org/10.7120/09627286.24.2.211

Groot Koerkamp, P. W. G., Middelkoop, J. H., \& Evers, E. (2000).

Ammoniakemissie vleeskuikenstallen toegenomen. Pluimveehouderij, 30, $10-11$.

Homidan, A. A., Robertson, J. F., \& Petchey, A. M. (2003). Review of the effect of ammonia and dust concentrations on broiler performance. World's Poultry Science Journal, 59(3), 340-349. doi:https://doi.org/10.1079/WPS20030021

Kjaer, J. B., Su, G., Nielsen, B. L., \& Sørensen, P. (2006). Foot pad dermatitis and hock burn in broiler chickens and degree of inheritance. Poultry Science, 85(8), 1342-1348. doi:https://doi.org/10.1093/ps/85.8.1342

Knowles, T. G., Kestin, S. C., Haslam, S. M., Brown, S. N., Green, L. E., Butterworth, A., . . . Nicol, C. J. (2008). Leg disorders in broiler chickens: prevalence, risk factors and prevention. PLoS One, 3(2), e1545. doi:https://doi.org/10.1371/journal.pone.0001545

Lagerkvist, C. J., Hansson, H., Hess, S., \& Hoffman, R. (2011). Provision of Farm Animal Welfare: Integrating Productivity and Non-Use Values. Applied Economic Perspectives and Policy, 33(4), 484-509. doi:https://doi.org/10.1093/aepp/ppr037

Leinonen, I., Williams, A. G., \& Kyriazakis, I. (2014). The effects of welfareenhancing system changes on the environmental impacts of broiler and egg production. Poultry Science, 93(2), 256-266. doi:https://doi.org/10.3382/ps.2013-03252

Leinonen, I., Williams, A. G., Wiseman, J., Guy, J., \& Kyriazakis, I. (2012). Predicting the environmental impacts of chicken systems in the United Kingdom through a life cycle assessment: Broiler production systems. Poultry Science, 91(1), 8-25. doi:https://doi.org/10.3382/ps.2011-01634

Lusk, J. L., \& McCluskey, J. (2018). Understanding the Impacts of Food Consumer Choice and Food Policy Outcomes. Applied Economic Perspectives and Policy, 40(1), 5-21. doi:https://doi.org/10.1093/aepp/ppx054

Lusk, J. L., \& Norwood, F. B. (2011). Animal Welfare Economics. Applied Economic Perspectives and Policy, 33(4), 463-483. doi:https://doi.org/10.1093/aepp/ppr036

Lusk, J. L., Pruitt, J. R., \& Norwood, F. B. (2006). Consumer Demand for a Ban on Antibiotic Drug Use in Pork Production. American Journal of Agricultural Economics, 88(4), 1015-1033. doi:https://doi.org/10.1111/j.1467$\underline{8276.2006 .00913 . x}$

Namroud, N. F., Shivazad, M., \& Zaghari, M. (2008). Effects of Fortifying Low Crude Protein Diet with Crystalline Amino Acids on Performance, Blood Ammonia Level, and Excreta Characteristics of Broiler Chicks. Poultry Science, 87(11), 2250-2258. doi:https://doi.org/10.3382/ps.2007-00499

Netherlands Enterprise Agency. (2020). Antibiotic resistance in the livestock industry. Retrieved from https://www.government.nl/topics/antibiotic- 
resistance/antibiotic-resistance-in-livestockfarming\#: : text=Less $\% 20$ antibiotic\%20use $\% 20$ in $\% 20$ the,have $\% 20$ fallen $\%$ 20by $\% 20$ another $\% 2011 \% 25$.

Peña Fernández, A., Demmers, T. G. M., Tong, Q., Youssef, A., Norton, T., Vranken, E., \& Berckmans, D. (2019). Real-time modelling of indoor particulate matter concentration in poultry houses using broiler activity and ventilation rate. Biosystems Engineering, 187, 214-225. doi:https://doi.org/10.1016/j.biosystemseng.2019.09.004

Plastina, A., \& Giannakas, K. (2007). Market and welfare effects of GMO introduction in small open economies. AgBioForum, 10(2), 104-123.

Reinders, M., Poppe, K. J., Immink, V., Van den Broek, E., Van Horne, P. L. M., \& Hoste, R. (2013). Waardevolle perspectieven voor vlees. Retrieved from Den Haag: https://edepot.wur.n1/296834

Riber, A. B., Van de Weerd, H. A., De Jong, I. C., \& Steenfeldt, S. (2018). Review of environmental enrichment for broiler chickens. Poultry Science, 97(2), 378-396. doi:https://doi.org/10.3382/ps/pex344

Rocchi, L., Paolotti, L., Rosati, A., Boggia, A., \& Castellini, C. (2019). Assessing the sustainability of different poultry production systems: A multicriteria approach. Journal of Cleaner Production, 211, 103-114. doi:https://doiorg.ezproxy.library.wur.nl/10.1016/j.jclepro.2018.11.013

Rodenburg, T. B., \& Koene, P. (2007). The impact of group size on damaging behaviours, aggression, fear and stress in farm animals. Applied Animal Behaviour Science, 103(3-4), 205-214. doi:https://doi.org/10.1016/j.applanim.2006.05.024

Rougoor, C., \& Van der Schans, F. (2019). Vergelijking milieueffecten vleeskuikenconcepten. Retrieved from https://www.pluimveeloket.be/sites/default/files/inline-files/201910\%20CLMrapport-Vergelijking_milieueffecten vleeskuikenconcepten.pdf

Saatkamp, H. W., Vissers, L. S. M., Van Horne, P. L. M., \& De Jong, I. C. (2019). Transition from conventional broiler meat to meat from production concepts with higher animal welfare: experiences from The Netherlands. Animals, 9(8). doi:https://doi.org/10.3390/ani9080483

Saitone, T. L., Sexton, R. J., \& Sumner, D. A. (2015). What Happens When Food Marketers Require Restrictive Farming Practices? American Journal of Agricultural Economics, 97(4), 1021-1043. doi:https://doi.org/10.1093/ajae/aav021

Segerson, K. (2013). When Is Reliance on Voluntary Approaches in Agriculture Likely to Be Effective? Applied Economic Perspectives and Policy, 35(4), 565-592. doi:https://doi.org/10.1093/aepp/ppt030

Sørensen, P., Su, G., \& Kestin, S. C. (2000). Effects of Age and Stocking Density on Leg Weakness in Broiler Chickens. Poultry Science 79(6), 864-870. doi:https://doi.org/10.1093/ps/79.6.864 


\section{Chapter 3}

Stadig, L. (2019). Vleeskuikenconcepten in Nederland. Retrieved from https://www.pluimveeloket.be/sites/default/files/inline-files/2019-1010\%20Welzijnsvergelijking\%20vleeskuikenconcepten.pdf

Stadig, L. M., Rodenburg, T. B., Ampe, B., Reubens, B., \& Tuyttens, F. A. M. (2017). Effect of free-range access, shelter type and weather conditions on free-range use and welfare of slow-growing broiler chickens. Applied Animal Behaviour Science, 192, 15-23. doi:https://doi.org/10.1016/j.applanim.2016.11.008

Swinnen, J., Deconinck, K., Vandemoortele, T., \& Vandeplas, A. (2015). Quality standards, value chains, and international development: economic and political theory. New York: Cambridge University Press.

Tullo, E., Fontana, I., Peña Fernández, A., Vranken, E., Norton, T., Berckmans, D., \& Guarino, M. (2017). Association between environmental predisposing risk factors and leg disorders in broiler chickens. Journal of Animal Science, 95(4), 1512-1520. doi:https://doi.org/10.2527/jas.2016.1257

Van Geijlswijk, I. M., Heederik, D., Mouton, J. W., Wagenaar, J. A., Jacobs, J. H., \& Sanders, P. (2019). Usage of Antibiotics in Agricultural Livestock in the Netherlands in 2018. Retrieved from https://cdn.ipulse.nl/autoriteitdiergeneesmiddelen/userfiles/Publications/2018-defrapport1.pdf

Van Harn, J., Dijkslag, M. A., \& van Krimpen, M. M. (2019). Effect of low protein diets supplemented with free amino acids on growth performance, slaughter yield, litter quality, and footpad lesions of male broilers. Poultry Science, 98(10), 4868-4877. doi:https://doi.org/10.3382/ps/pez229

Van Horne, P. L. M. (2017). Competitiveness of the EU poultry meat sector, base year 2015; International comparison of production costs. Retrieved from http://edepot.wur.nl/404949

Van Horne, P. L. M. (2020). Economics of broiler production systems in the Netherlands: economic aspects within the Greenwell sustainability assessment model. Retrieved from Wageningen: https://edepot.wur.nl/518522

Verspecht, A., Vanhonacker, F., Verbeke, W., Zoons, J., \& Van Huylenbroeck, G. (2011). Economic impact of decreasing stocking densities in broiler production in Belgium. Poultry Science, 90(8), 1844-1851. doi:https://doi.org/10.3382/ps.2010-01277

Vissers, L. S. M., De Jong, I. C., van Horne, P. L. M., \& Saatkamp, H. W. (2019). Global prospects of the cost-efficiency of broiler welfare in middlesegment production systems. Animals (Basel), 9(7). doi:https://doi.org/10.3390/ani9070473

Vissers, L. S. M., Jongeneel, R. A., Saatkamp, H. W., \& Oude Lansink, A. G. J. M. (2021a). A multiple-standards framework to address externalities resulting from meat production. Applied Economic Perspectives and Policy, 1-14. doi:https://doi.org/10.1002/aepp.13152 
Vissers, L. S. M., Saatkamp, H. W., \& Oude Lansink, A. G. J. M. (2021b).

Analysis of synergies and trade-offs between animal welfare, ammonia emission, particulate matter emission and antibiotic use in Dutch broiler production systems. Agricultural Systems, 189, 103070. doi:https://doi.org/10.1016/j.agsy.2021.103070

Waldenstedt, L. (2006). Nutritional factors of importance for optimal leg health in broilers: A review. Animal Feed Science and Technology, 126(3), 291-307. doi:https://doi.org/10.1016/j.anifeedsci.2005.08.008

Welfare Quality Protocol® ${ }^{\circledR}$. (2009). Welfare Quality ${ }^{\circledR}$ assessment protocol for poultry (broilers, laying hens). Retrieved from https://edepot.wur.nl/233471

Winkel, A., Mosquera, J., Groot Koerkamp, P. W. G., Ogink, N. W. M., \& Aarnink, A. J. A. (2015). Emissions of particulate matter from animal houses in the Netherlands. Atmospheric Environment, 111, 202-212. doi:https://doi.org/10.1016/j.atmosenv.2015.03.047 


\section{Chapter 4}

\section{Exploring the performance of system changes in Dutch broiler production to balance animal welfare, ammonia emissions and particulate matter emissions with farm profitability}

Luuk S.M. Vissers, Alfons G.J.M Oude Lansink, Helmut W. Saatkamp

Published in Agricultural Systems. Volume 193, October 2021. DOI: https://doi.org/10.1016/j.agsy.2021.103217 


\title{
Chapter 4
}

\begin{abstract}
In response to societal concerns, the European Union (EU) and the EU poultry meat sector set up goals to address the negative impact of intensive broiler production on animal welfare, the environment and human health. This paper aimed to 1) explore combinations of system changes that perform best in terms of farm income, animal welfare, emissions of ammonia $\left(\mathrm{NH}_{3}\right)$ and particulate matter $\left(\mathrm{PM}_{10}\right)$ and 2$)$ are robust to changes in society's expectations relating to animal welfare and environmental sustainability. The prevailing system in the Dutch broiler market was used as a baseline for evaluating system changes. Animal welfare, $\mathrm{NH}_{3}$ emissions and $\mathrm{PM}_{10}$ emissions were the three external factors chosen for this evaluation. Farm income was quantified by the net return to labor and management (NRLM). Expert knowledge elicitation was used to identify system changes that were likely to be implemented in the baseline system. Combinations were made by selecting system changes from each of the chosen external factors. A deterministic model was used to calculate the effect of each combination of system changes on net return to labor and management. The performance of each combination was evaluated by estimating a benefit-of-the-doubt composite indicator. Results show that 8 out of 70 combinations indicated a better outcome and were more robust to potential changes in society's expectations relating to animal welfare and environmental sustainability. These combinations included two or more of the following system changes: 'lower density' $\left(30 \mathrm{~kg} / \mathrm{m}^{2}\right)$, ' 2 types of enrichment', and 'daylight'. Furthermore, these combinations included 'tube heaters' for the abatement of $\mathrm{NH}_{3}$ emissions, and 'negative air ionization system' or 'ionization filter' for the abatement of $\mathrm{PM}_{10}$ emissions. To compensate for the decrease in NRLM associated with these practices and abatement techniques, a price premium was required that ranged between 4.8 and 18.5 eurocents/broiler. We conclude that combinations including animal welfare related system changes (lower density, enrichment and/or daylight), tube heaters and an ionization technique performed best and were robust to changes of societal expectations of these external factors. The insights obtained from this paper can support decision making in improving the sustainability of current broiler production systems.
\end{abstract}

Keywords: Broiler production; Animal welfare; Ammonia; Particulate matter; Composite indicator 


\subsection{Introduction}

Since the mid- $20^{\text {th }}$ century, stakeholders in the European broiler supply chain codeveloped intensive broiler production systems to address the increasing demand for safe and cheap food in sufficient quantities. More recently these systems have been criticized by European citizens because of a perceived effect on animal welfare (AW), the environment and human health (Homidan et al., 2003; Bessei, 2006; Cambra-López et al., 2010), defined as external factors ${ }^{1}$. In the past two decades, the European Union (EU) passed legislation on AW, food safety and the environment to address these concerns (European Council Directive, 2007, 2009, 2016). Stakeholders in the broiler supply chain introduced more extensive broiler production systems to address the critique on AW. These systems provided a higher level of AW, but had a higher environmental impact relative to conventional systems (Leinonen et al., 2012; Bracke et al., 2019). Therefore, the attempts by the EU and private sector are deemed to be insufficient by European citizens as criticism persists as of today (Eurobarometer, 2016). In order to address the persistent societal critique, the EU agreed upon new goals for the next ten years. In 2016, the European Commission (2020) introduced the Farm to Fork strategy, which set goals specific to the agri-food sector such as a reduction in the nutrient losses and the sales of antimicrobials for farmed animals by $50 \%$ in 2030. A potential pathway towards achieving these goals is to improve the sustainability of current broiler production systems. To improve the sustainability of these systems, investigation into the impact of specific, objective system changes ${ }^{2}$ on farm income is of great importance. However, it is currently unclear which system changes address external factors in an income-efficient manner ${ }^{3}$.

Earlier studies, such as Wagner et al. (2015) and Vissers et al. (2021c), developed an integrated model to analyze the effectiveness and cost-efficiency of system changes on external factors in poultry production. Wagner et al. (2015) investigated the effect of ammonia $\left(\mathrm{NH}_{3}\right)$ and particulate matter (Raedts et al.) related system changes with regards to their costs for farmers and their benefits for society. Vissers et al. (2021c) analyzed the synergies and trade-offs between AW,

\footnotetext{
${ }^{1}$ In chapters 3 and 4, we use the term external factor. In the remainder of the dissertation we use the term externalities.

${ }^{2}$ In this paper, we define a system change as a change of the production system in one of the following aspects: 1) a different management practice 2) a change in the housing design or 3) implementation of (a different) end-of-pipe air treatment technique.

${ }^{3}$ A system change is considered to be income-efficient when an external factor is reduced by a certain level with a minimum decrease in farm income.
} 


\section{Chapter 4}

antibiotic use, $\mathrm{NH}_{3}$ emissions and $\mathrm{PM}_{10}$ emissions in broiler production systems. While Wagner et al. (2015) considered only system changes related to $\mathrm{NH}_{3}$ and $\mathrm{PM}$ emissions, Vissers et al. (2021c) considered only AW related system changes. Therefore, these studies do not consider the costs and benefits of broiler production systems that include combined system changes of $\mathrm{AW}, \mathrm{NH}_{3}$ and $\mathrm{PM}_{10}$ emissions. Another shortcoming of both studies is that they ignore the potential for addressing $\mathrm{AW}, \mathrm{NH}_{3}$ emissions and $\mathrm{PM}_{10}$ emissions simultaneously by combining these system changes, and the impact of these combinations on farm income. Because of these shortcomings, the existing studies are not able to answer the following questions:

- How can the performance of system changes on farm income and external factors be measured?

- What are the best performing system changes to address these external factors?

- To what extent is the performance of these system changes robust to changes in the societal attitude towards these external factors?

- What is the price premium or subsidy required to compensate for the decrease in farm income associated with these changes?

To answer these questions, this paper aims to explore combinations of system changes that perform relatively best in terms farm income and external factors, and are robust to changes of societal expectations of these external factors. The insights obtained from this paper can support the development of broiler production systems that deliver the greatest combinations for reduced environmental emissions, improved AW and reduced risks relating to human health. Furthermore, the study can provide insights for determining the minimum price premium or subsidy needed to get support for the systems among farmers.

\subsection{Approach}

A five-step approach was developed and applied to a Dutch broiler production system to assess the effect of altering the production system using defined system changes on $\mathrm{AW}, \mathrm{NH}_{3}$ and $\mathrm{PM}_{10}$ emissions, and farm income. First, the baseline system that was used for implementation of the system changes is described. Second, the external factors and system changes considered in this study are discussed. This is followed by a description of the model that was used to calculate the impact of the system changes on the external factors and farm income. Fourth, the system changes are compared in terms of their overall performance using the 
benefit-of-the-doubt method. Finally, a sensitivity analysis was conducted to test the sensitivity of the overall performance of the system changes to fluctuations in the feed price and producer price.

\subsubsection{Select baseline broiler production system}

The new Dutch retail standard system was selected as the baseline system, as this is the prevailing system in the Dutch fresh meat market (Saatkamp et al., 2019). The new Dutch retail standard contains the minimum requirements on AW of Dutch retailers, which go beyond the minimum legal requirements laid down by the EU (European Council Directive, 2007). The requirements of this standard entail a slower-growing breed (max. growth rate $50 \mathrm{~g} /$ day), a maximum stocking density of $38 \mathrm{~kg} / \mathrm{m}^{2}$ and the provision of straw bale enrichment. Table 4.1 shows the attributes of the new Dutch retail standard system. We assumed that this system included two techniques for reducing $\mathrm{NH}_{3}$ and $\mathrm{PM}_{10}$ emissions, i.e. indirect heaters with circulation and a heat exchanger. These techniques were selected as they are widely used in the new Dutch retail standard system (H.H. Ellen, personal communication, 2020).

Table 4.1 System attributes of the baseline system (obtained from Vissers et al. (2021c))

\begin{tabular}{lll}
\hline System attribute & Unit & $\begin{array}{l}\text { Production system } \\
\text { New Dutch Retail Standard }\end{array}$ \\
\hline Broiler type & Type & Hubbard JA 987 \\
Length growth period & days & 49 \\
Weight at delivery & $\mathrm{g}$ & 2,380 \\
Stocking density & $\mathrm{kg} / \mathrm{m}^{2}$ & Max. 38 \\
Straw bale enrichment & \# bales/ 1,000 broilers & Min. 1 \\
Grain enrichment & g/broiler & Not required \\
Length dark period & hours/day & Min. 6 \\
Light intensity & lux & Min. 20 \\
Natural light & yes/no & Not required \\
On-farm hatching & yes/no & Not required \\
Early feeding & yes/no & Not required \\
Empty barn period & \# days & 7 \\
Litter type & Type & Wood shavings \\
Feed composition & Type & Concentrates $+15 \%$ wheat \\
Feeding phases & \# phases & 4 \\
Management of manure & Type & Disposed at end of production cycle \\
Flock size & \# broilers & 81,035 \\
Veterinary medicines & Type & Antimicrobials and coccidiostats \\
Outdoor access & yes/no & Not required \\
NH $H_{3}$ abatement technique & Type & Indirect heaters with circulation \\
PM & Type abatement technique & Heat exchanger 13\% PM 10 emission \\
& rypeduction \\
\hline & &
\end{tabular}




\section{Chapter 4}

\subsubsection{Identifying societal expectations for animal welfare and environmental sustainability}

A list of external factors related to Dutch broiler production was obtained from Vissers et al. (2021c). Based on this list, expert knowledge elicitation (see Appendix 4A for the list of experts and their expertise) was used to identify the external factors that are key drivers in the development of Dutch broiler production systems in the next ten years (2020-2030). A time span of ten years was selected because the time scale of a transition driven by aroused public opinion on societal issues is usually a decade (Buurma et al., 2017). External factors including AW, $\mathrm{NH}_{3}$ emissions, odour emissions and $\mathrm{PM}_{10}$ emissions were selected by the experts. Odour emissions were not considered in further analysis, as data about odour emissions were lacking for the new Dutch retail standard production system. Since odour from broiler houses is a complex mixture of odorous compounds typically composed of volatile organic compounds (Dunlop et al., 2016), it was also not possible to estimate the odour emissions originating from the baseline system using expert knowledge elicitation. For the selected external factors, expert knowledge elicitation was carried out to identify the system changes that are likely to be implemented in the baseline system in the next ten years. Table 4.2 provides an overview of the selected system changes, and their likelihood for implementation. The selection of the system changes may be biased due to the research interests and/or experience of the experts. Therefore, we included a substantiation of the selected system changes in Appendix 4B. On top of the system changes selected by the experts, the management practices and $\mathrm{NH}_{3} / \mathrm{PM}_{10}$ abatement techniques already applied in the baseline system were considered in the analysis (defined as "no system change' in Table 4.2). 
Table 4.2 Overview of the system changes selected in this study and likelihood to be implemented in the new Dutch Retail standard system in the next 10 years

\begin{tabular}{lll}
\hline External factor & System changes & Likelihood \\
\hline Animal welfare & 1. 2 types of enrichment ${ }^{1}+$ daylight $^{2}$ & High \\
& 2. Lower density +2 types of enrichment & Low \\
& 3. Lower density + daylight & Low \\
& 4. Lower density +2 types of enrichment + daylight & Low \\
& 5. No system change & Low \\
& 1. Tube heaters & High \\
$\mathrm{NH}_{3}$ emissions & 2. TerraSea & Low \\
& 3. Chemical air scrubber, $70 \% \mathrm{NH}_{3}$ reduction, 35\% & Low \\
& $\mathrm{PM}_{10}$ reduction & \\
& 4. No system change & Low \\
& 1. Negative air ionization system & Low \\
$\mathrm{PM}_{10}$ emissions & 2. Ionization filter & Low \\
& 3. Heat exchanger 31\% $\mathrm{PM}_{10}$ reduction & Low \\
& 4. No system change & Low \\
\hline
\end{tabular}

${ }^{1}$ Types of enrichment: 2 straw bales/1,000 broilers and $2 \mathrm{~g}$ grain/day/broiler.

${ }^{2}$ Daylight: $3 \%$ of surface area.

${ }^{3}$ Reduction from $38 \mathrm{~kg} / \mathrm{m}^{2}$ to $30 \mathrm{~kg} / \mathrm{m}^{2}$.

${ }^{4}$ Tube heaters are installed inside the broiler house nearby the side wall inlets. The intake air passes through the air inlet and is warmed up by the tube heaters. The hot air absorbs moisture that evaporates from the litter. The moisture-rich air is removed with ventilation fans.

${ }^{5}$ In the Terrasea system, intake air passes through heat exchanger tubes where an energy transfer (heating or cooling) takes place. Water runs through these tubes, which cools the air in the summer and warms it in the winter. A chemical air scrubber removes ammonia, odour and particulate matter from the exhaust air.

\subsubsection{Calculating the effect of the system changes on animal welfare, environmental sustainability and net farm income}

\section{Farm income}

Based on the chosen system changes, combinations were made by selecting system changes from each external factor. Technically infeasible combinations of system changes were excluded from further analysis, resulting in 70 feasible combinations (out of potential 80 combinations). The deterministic model of Vissers et al. (2021c) was used to calculate the external factors and farm income originating from the baseline system, and the effect of each combination of system changes on the external factors and farm income. In line with Vissers et al. (2021c), we assumed that 81,035 broilers were reared the baseline system. Farm income was measured as the net return to labor and management (NRLM) and was computed as total revenues minus total costs excluding labor costs in euro per farm per year. The technical performance indicators, input prices and producer prices were 


\section{Chapter 4}

obtained from Blanken et al. (2019). Table 4.3 provides an overview of the annual costs of each system change. Currently, farmers can apply for a subsidy for which $40 \%$ of the investment costs in an indoor $\mathrm{PM}_{10}$ abatement technique are reimbursed (Netherlands Enterprise Agency, 2020b). This reimbursement applies only to indoor $\mathrm{PM}_{10}$ abatement techniques with a reduction efficiency of $45 \%$ or higher. Only the 'negative air ionization system' meets this requirement. Therefore, a $40 \%$ reduction in the investment costs was considered for this technique. The producer price was assumed to be fixed. Hence, system changes that enhance production costs lower the NRLM. Furthermore, floor surface area was assumed to be fixed. Hence, a lower stocking density implies less broilers reared in the poultry house. The net present value method was used to calculate the total subsidy required to compensate for the decrease in NRLM associated with the system changes. The decrease in NRLM was discounted over a period of 12.5 years, which is based on the economic lifespan of the $\mathrm{NH}_{3}$ and $\mathrm{PM}_{10}$ abatement techniques (Blanken et al., 2019). The decrease in NRLM was discounted to present values using a $2.33 \%$ discount rate (Blanken et al., 2019). The formulas that have been used to calculate the required price premium and subsidy are provided in Appendix 4C.

\section{External factors}

The external factors $\mathrm{NH}_{3}$ emissions and $\mathrm{PM}_{10}$ emissions were expressed in $\mathrm{kg}$ per farm per year and include only emissions at the farm gate. $\mathrm{The}^{\mathrm{NH}_{3}}$ and $\mathrm{PM}_{10}$ emissions originating from the baseline system were obtained from Vissers et al. (2021c). The $\mathrm{NH}_{3}$ and $\mathrm{PM}_{10}$ reduction efficiencies of the abatement techniques were obtained from Expertise Centre Infomil (2019a) (see Table 4.3). Tools developed by the Dutch National Institute for Public Health and Environment (2017) and the Dutch Ministry of Instrastructure and Water Management (2020) were used to calculate the $\mathrm{NH}_{3}$ and $\mathrm{PM}_{10}$ reduction efficiency from each combination of system changes. Vissers et al. (2021c) found that the system changes 'lower density', ' 2 types of enrichment' and 'daylight' elevate $\mathrm{PM}_{10}$ emissions (expressed in $\mathrm{g} \mathrm{PM}_{10}$ /animal place/year) (Vissers et al., 2021c).

Furthermore, they found that a reduction in stocking density may elevate $\mathrm{NH}_{3}$ emissions (expressed in $\mathrm{kg} \mathrm{NH}_{3}$ /animal place/year). However, Vissers et al. (2021c) provide only a qualitative assessment of the effect of these system changes on $\mathrm{NH}_{3}$ and $\mathrm{PM}_{10}$ emissions. Since a quantitative assessment of these effects was lacking, we assumed that the system changes do not affect $\mathrm{PM}_{10}$ emissions and $\mathrm{NH}_{3}$ emissions. 
Performance of system changes

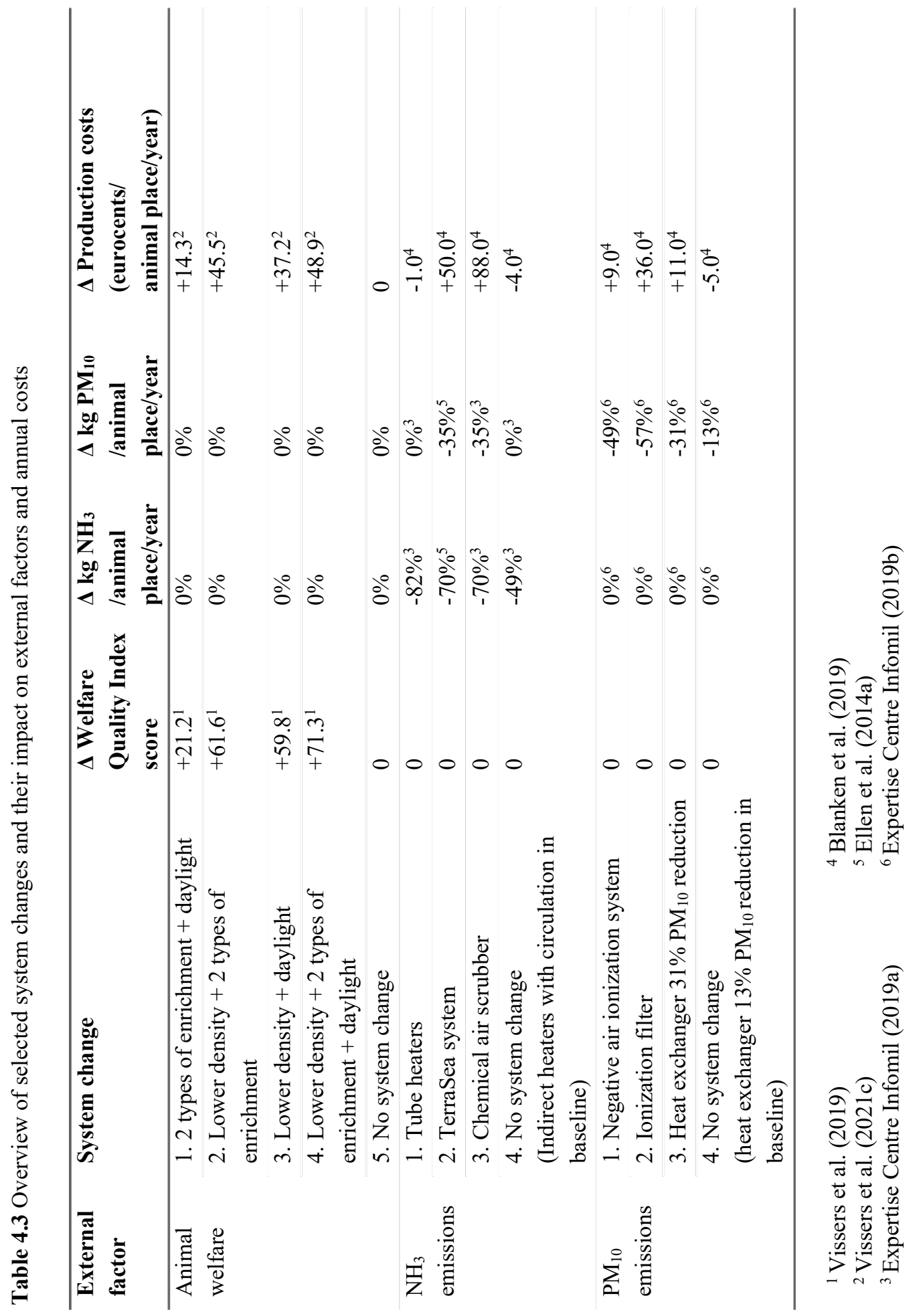




\section{Chapter 4}

The level of AW was indicated by the welfare quality index score (Welfare Quality Protocol $\left.{ }^{\circledR}, 2009\right)$. The welfare quality index score of the baseline system was obtained from Vissers et al. (2019). This study was also consulted to obtain the effect of the system changes 'lower density', '2 types of enrichment' and 'daylight' on the welfare quality index score. Cambra-López et al. (2009), Bokkers et al. (2010) and Van Harn et al. (2015) analyzed the effect of the selected $\mathrm{NH}_{3}$ and $\mathrm{PM}_{10}$ abatement techniques on technical performance and/or welfare related parameters such as footpad dermatitis and mortality. These studies did not find statistically significant differences between the techniques on broiler performance and welfare related parameters. Based on these findings, we assumed that the implementation of the selected techniques in the baseline system did not affect the welfare quality index score and the technical performance indicators.

\subsubsection{Evaluate performance of combination of system changes}

The performance of each combination of system changes was evaluated by developing a composite indicator. A composite indicator is a mathematical aggregation of a set of sub-indicators for measuring multidimensional concepts that cannot be captured by a single indicator (OECD, 2008). Composite indicators are increasingly used for performance comparisons, benchmarking and policy evaluation and is used in wide-ranging fields such as economy, society and technological development (OECD, 2008). In this study, the composite indicator consisted of four sub-indicators, i.e. NRLM, level of $\mathrm{AW}, \mathrm{NH}_{3}$ emissions and $\mathrm{PM}_{10}$ emissions (see Figure 4.1).

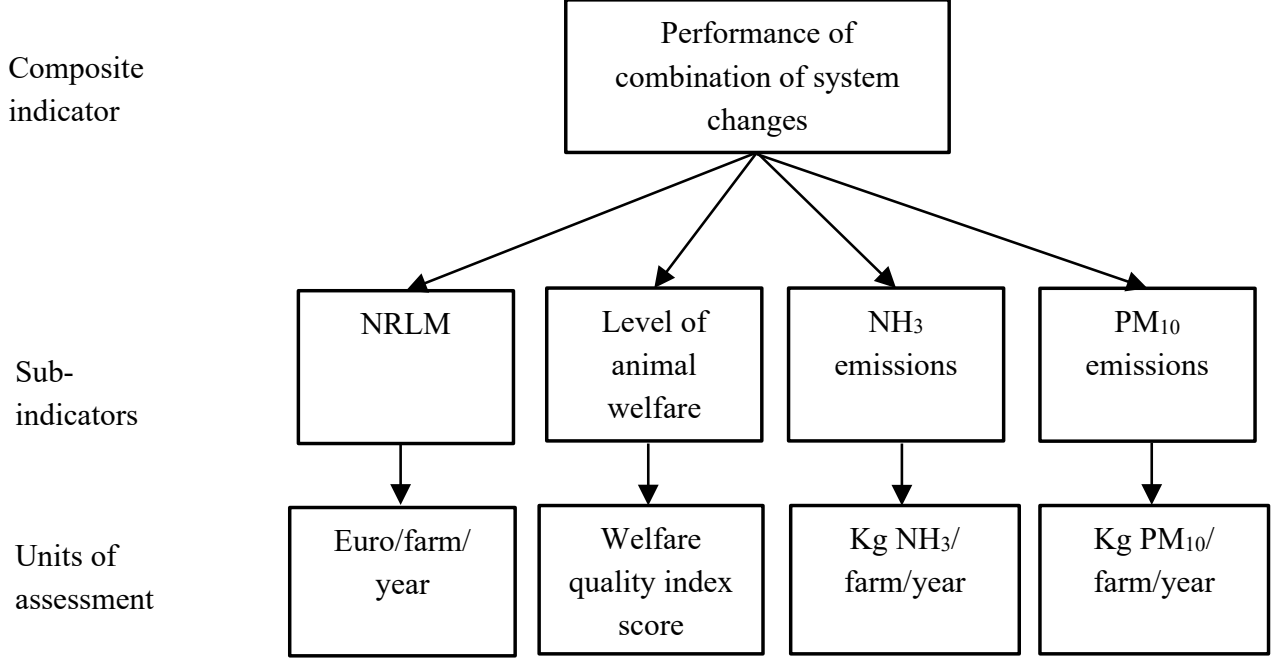

Figure 4.1 Decomposition of composite indicator into sub-indicators 
Various weighting methods can be applied to aggregate the sub-indicators into a composite indicator, such as a linear aggregation method or the benefit-of-thedoubt approach (OECD, 2008). The benefit-of-the-doubt approach as proposed by Cherchye et al. (2007) was used to aggregate the sub-indicators into a composite performance indicator. The benefit-of-the-doubt approach is a technique that uses Data Envelopment Analysis to construct an indicator that is defined as the ratio of an observation's actual performance to its benchmark performance (the frontier). A value of 1 implies a performance similar to the benchmark values and a value less than 1 refers to worse performance. Figure 4.2 illustrates the approach for two subindicators. Observations $\mathrm{A}, \mathrm{B}$ and $\mathrm{C}$ are on the frontier, indicating that they are the best performing observations with a performance score that equals 1 . Observation $\mathrm{D}$ has a performance score lower than 1 , as it can improve the score of subindicator 1 without reducing the score of sub-indicator 2 (or vice versa). The performance score of observation $\mathrm{D}$ is calculated by the ratio of two distances, namely distance O-B and distance O-D.

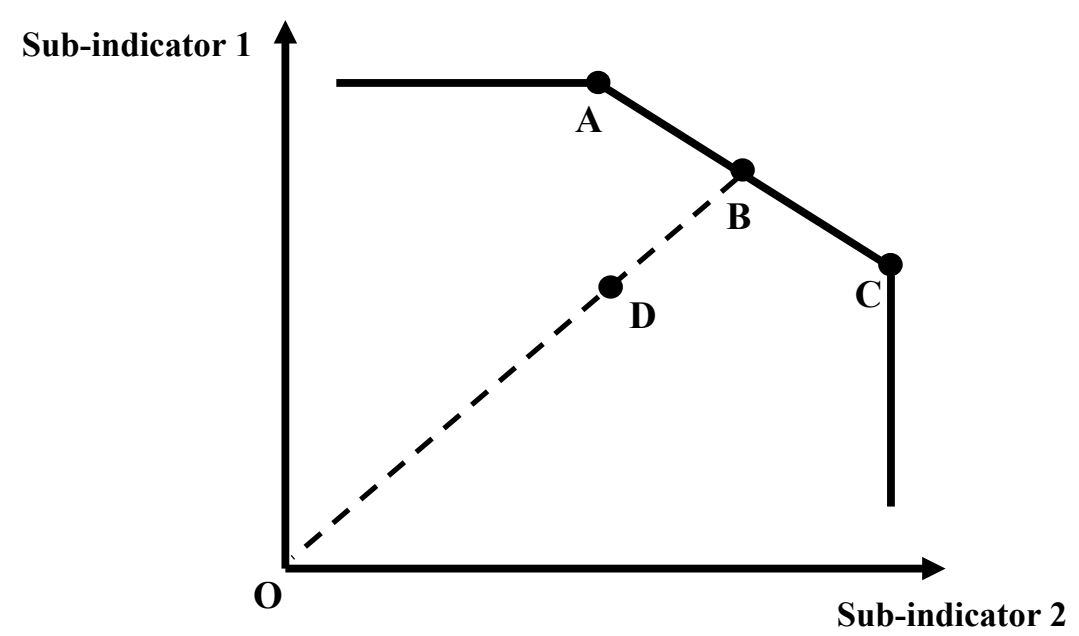

Figure 4.2 Schematic representation of an output oriented data envelopment analysis model

The benefit-of-the-doubt model is summarized in equations (1), (2) and (3). In the model, $I_{c}$ corresponds to the composite indicator of a combination of system changes $c(c=1, \ldots, n)$. The variable $y_{c, i}$ is the bundle of $i$ sub-indicators $(i=$ $1, \ldots, m)$ generated by a combination of system changes $c$. The sub-indicators were defined such that 'the more the better' holds. Therefore, $\mathrm{NH}_{3}$ emissions and $\mathrm{PM}_{10}$ emissions were expressed as 'reduced $\mathrm{NH}_{3}$ emissions and $\mathrm{PM}_{10}$ emissions relative to the baseline system'. The 'reduced $\mathrm{NH}_{3}$ emissions and $\mathrm{PM}_{10}$ emissions 


\section{Chapter 4}

relative to the baseline system' were obtained by calculating the decrease in $\mathrm{NH}_{3}$ and $\mathrm{PM}_{10}$ emissions caused by a combination of system changes, relative to the baseline system. The weights $w_{c, i}$ are the variables of the model. The model optimizes the weights such that the maximum score for each combination is achieved. The benefit-of-the-doubt model was programmed using the package linprog in R Software (R Core team, 2020).

$$
I_{c}=\max \sum_{i=1}^{m} w_{c, i} y_{c, i}
$$

Subject to

$$
\begin{array}{ll}
\sum_{i=1}^{m} w_{c, i} y_{j, i} \leq 1 & i=1, \ldots, m \\
w_{c, i} \geq 0 & c=1, \ldots, n
\end{array}
$$

Apart from the non-negativity of the weights, the model hitherto discussed allows weights to be freely estimated in order to maximize the performance score of the evaluated combination of system changes. In practice, society may assign a higher weight to a sub-indicator (e.g. AW) compared to the other sub-indicators. To address this issue, ordinal sub-indicator share restrictions were added to the model. Ordinal sub-indicator share restrictions imply that the sub-indicator shares of subindicator $\mathrm{i}\left(w_{i} * y_{i}\right)$ are ordinally ranked based on their importance (Cherchye et al., 2007). A default scenario was developed in which a higher importance was assigned to NRLM relative to the external factors (so-called NRLM driven scenario). An equal importance was assigned to the external factors (AW, $\mathrm{NH}_{3}$ emissions and $\mathrm{PM}_{10}$ emissions). Similarly, three scenarios for the external factors (AW, $\mathrm{NH}_{3}$ and $\mathrm{PM}_{10}$ driven) were explored. An overview of the scenarios is provided in Table 4.4. By changing the ranking of the external factors, the robustness of a performance score to changes in the importance of the external factors was tested. In this study, we assumed that a combination of system changes was robust and performed relatively best when a performance score of 0.90 or higher was achieved in all scenarios. 
Table 4.4 Overview of sub-indicator share restrictions per scenario

\begin{tabular}{|c|c|c|c|}
\hline NRLM driven & AW driven & $\mathrm{NH}_{3}$ driven & PM10 driven \\
\hline AW $<$ NRLM & NRLM $<$ AW & $\begin{array}{l}\mathrm{NRLM}<\mathrm{NH}_{3} \\
\text { emissions }\end{array}$ & $\begin{array}{l}\text { NRLM }<\mathrm{PM}_{10} \\
\text { emissions }\end{array}$ \\
\hline $\begin{array}{l}\mathrm{NH}_{3} \text { emissions } \\
<\text { NRLM }\end{array}$ & $\begin{array}{l}\mathrm{NH}_{3} \text { emissions } \\
<\mathrm{AW}\end{array}$ & $\begin{array}{l}\mathrm{AW}<\mathrm{NH}_{3} \\
\text { emissions }\end{array}$ & $\begin{array}{l}\mathrm{AW}<\mathrm{PM}_{10} \\
\text { emissions }\end{array}$ \\
\hline $\mathrm{PM}_{10}$ emissions & $\mathrm{PM}_{10}$ emissions & $\mathrm{PM}_{10}$ emissions & $\mathrm{NH}_{3}$ emissions \\
\hline$<$ NRLM & $<\mathrm{AW}$ & $<\mathrm{NH}_{3}$ emissions & $<\mathrm{PM}_{10}$ emissions \\
\hline
\end{tabular}

\subsubsection{Sensitivity analysis}

A sensitivity analysis was carried out to test effect of changes in the feed price and the producer price on the performance score of the combinations. The feed price and producer price were selected as Gocsik et al. (2013) show that the income of the broiler farmer is most responsive to changes in these prices. Two scenarios were modeled, i.e. a one standard deviation increase in feed price and a one standard deviation increase in producer price. The standard deviation was calculated by using monthly feed prices and producer prices over a time span of five years (2015-2019). Only yearly producer prices were available for the new Dutch retail standard system. However, monthly producer prices were available for the conventional system. Therefore, the average price premium was calculated by subtracting the yearly producer prices of the conventional system from the yearly producer prices of the new Dutch retail standard system. Consequently, the monthly producer prices of the new Dutch retail standard system were calculated by adding the average price premium to the conventional monthly producer prices.

\subsection{Results}

\subsubsection{Calculation of scores for combinations in the NRLM driven scenario} To identify the combinations of system changes that performed best in the NRLM driven scenario, the performance score of each combination was analyzed. An overview of the scores per scenario is provided in Appendix 4D. The results show that in the NRLM driven scenario, a reasonable amount of combinations ( 9 out of 70) had a performance score of 1 . This score implies that it was not possible to reduce an external factor (e.g. AW) without decreasing the NRLM or elevating another external factor (e.g. $\mathrm{NH}_{3}$ emissions). These combinations contained 'tube heaters' or 'indirect heaters with circulation' to reduce $\mathrm{NH}_{3}$ emissions, and a 'heat exchanger $13 \% \mathrm{PM}_{10}$ reduction' or an 'air ionization system' to reduce $\mathrm{PM}_{10}$ emissions. Furthermore, these combinations included 'no system change' on AW, 


\section{Chapter 4}

or a combination of 'lower density' (from $38 \mathrm{~kg} / \mathrm{m}^{2}$ to $30 \mathrm{~kg} / \mathrm{m}^{2}$ ), '2 types of enrichment' and 'daylight'. Most combinations (47 out of 70 ) had a performance score ranging between 0.70 and 0.99 . Hence, these combinations were relatively income-efficient, i.e. mitigated the external factors at a relatively small decrease in NRLM. A relatively small amount of combinations (14 out of 70) had a performance score lower than 0.70 . These combinations contained a 'chemical air scrubber' combined with 'negative air ionization system' or an 'ionization filter'.

\subsubsection{Calculation of scores for combinations in each scenario}

The performance score of the combinations was analyzed for each scenario, to assess whether the best performing combinations in the NRLM driven scenario were also robust to changes of societal expectations of the external factors. A combination was considered to be best performing and robust when a score of 0.90 or higher was achieved in all scenarios. Results show that combinations that did not include system changes on $\mathrm{AW}, \mathrm{NH}_{3}$ emissions and $\mathrm{PM}_{10}$ emissions did not satisfy this criteria. For instance, combinations that did not include a system change on AW had a maximum score of 0.85 in the AW driven scenario. Combinations that included a 'chemical air scrubber' had a relatively high performance score in the $\mathrm{NH}_{3}$ and $\mathrm{PM}_{10}$ driven scenario (maximum score of 1). However, these combinations performed worse in the NRLM driven scenario (maximum score of 0.68). Therefore, these combinations were not robust. Only 8 out of 70 combinations satisfied the best performing and robust criteria (Table 4.5). These combinations contained two or more of the following system changes related to AW: 'lower density', '2 types of enrichment' and/or 'daylight'. Furthermore, these combinations included 'tube heaters' to reduce $\mathrm{NH}_{3}$ emissions, and 'negative air ionization system' or an 'ionization filter' to reduce $\mathrm{PM}_{10}$ emissions. The best performing and robust combinations that included an 'ionization filter' performed slightly worse in the NRLM driven scenario compared to the combinations that included 'negative air ionization system'. Only the combination 'lower density + daylight', 'tube heaters' and 'negative air ionization system' had a performance score of 1 in all assessment areas (NRLM, AW, $\mathrm{NH}_{3}$ emissions and $\mathrm{PM}_{10}$ emissions). 


\section{Performance of system changes}

Table 4.5 Overview of performance score of combinations that were robust and performed relatively best

\begin{tabular}{|c|c|c|c|c|c|c|c|}
\hline Nr. & $\begin{array}{l}\text { AW-related } \\
\text { system change }\end{array}$ & $\begin{array}{l}\mathrm{NH}_{3} \text {-related } \\
\text { system change }\end{array}$ & $\begin{array}{l}\mathrm{PM}_{10} \text {-related } \\
\text { system change }\end{array}$ & $\begin{array}{l}\text { NRLM } \\
\text { driven }\end{array}$ & $\begin{array}{l}\text { AW } \\
\text { driven }\end{array}$ & $\begin{array}{l}\mathrm{NH}_{3} \\
\text { driven }\end{array}$ & $\begin{array}{l}\mathrm{PM}_{10} \\
\text { driven }\end{array}$ \\
\hline 1. & $\begin{array}{l}2 \text { types of } \\
\text { enrichment }+ \\
\text { daylight }\end{array}$ & Tube heaters & $\begin{array}{l}\text { Negative air } \\
\text { ionization } \\
\text { system }\end{array}$ & 1.00 & 0.92 & 0.99 & 0.95 \\
\hline 2. & $\begin{array}{l}2 \text { types of } \\
\text { enrichment }+ \\
\text { daylight }\end{array}$ & Tube heaters & $\begin{array}{l}\text { Ionization } \\
\text { filter }\end{array}$ & 0.95 & 0.90 & 0.96 & 0.96 \\
\hline 3. & $\begin{array}{l}\text { Lower density } \\
+ \text { daylight }\end{array}$ & Tube heaters & $\begin{array}{l}\text { Negative air } \\
\text { ionization } \\
\text { system }\end{array}$ & 1.00 & 1.00 & 1.00 & 1.00 \\
\hline 4. & $\begin{array}{l}\text { Lower density } \\
+2 \text { types of } \\
\text { enrichment }\end{array}$ & Tube heaters & $\begin{array}{l}\text { Negative air } \\
\text { ionization } \\
\text { system }\end{array}$ & 0.99 & 0.99 & 1.00 & 0.99 \\
\hline 5. & $\begin{array}{l}\text { Lower density } \\
+2 \text { types of } \\
\text { enrichment }+ \\
\text { daylight }\end{array}$ & Tube heaters & $\begin{array}{l}\text { Negative air } \\
\text { ionization } \\
\text { system }\end{array}$ & 0.99 & 1.00 & 1.00 & 1.00 \\
\hline 6. & $\begin{array}{l}\text { Lower density } \\
+ \text { daylight }\end{array}$ & Tube heaters & $\begin{array}{l}\text { Ionization } \\
\text { filter }\end{array}$ & 0.96 & 1.00 & 1.00 & 1.00 \\
\hline 7. & $\begin{array}{l}\text { Lower density } \\
+2 \text { types of } \\
\text { enrichment }\end{array}$ & Tube heaters & $\begin{array}{l}\text { Ionization } \\
\text { filter }\end{array}$ & 0.94 & 0.99 & 1.00 & 1.00 \\
\hline 8. & $\begin{array}{l}\text { Lower density } \\
+ \text { daylight }+2 \\
\text { types of } \\
\text { enrichment }\end{array}$ & Tube heaters & $\begin{array}{l}\text { Ionization } \\
\text { filter }\end{array}$ & 0.94 & 1.00 & 1.00 & 1.00 \\
\hline
\end{tabular}

\subsubsection{Impact on NRLM and external factors}

For each best performing and robust combination, the effect on NRLM and external factors was analyzed. Furthermore, the price premium or subsidy required to compensate for the decrease in NRLM was analyzed. Table 4.6 shows the effect of each best performing and robust combination of system changes on NRLM and external factors, compared with the baseline system (see section 4.2.1). These combinations were ranked from the best outcome to the worst outcome in terms of NRLM. The first combination included ' 2 types of enrichment + daylight', 'tube heaters' and 'negative air ionization system'. Results show that this combination reduced all external factors ( $\mathrm{AW}, \mathrm{NH}_{3}$ and $\mathrm{PM}_{10}$ emissions) at a reasonable decrease in NRLM (-29.3\%). To compensate for this decrease in NRLM, a price premium of 4.8 eurocents/broiler or a subsidy of 318.6 thousand euros was 


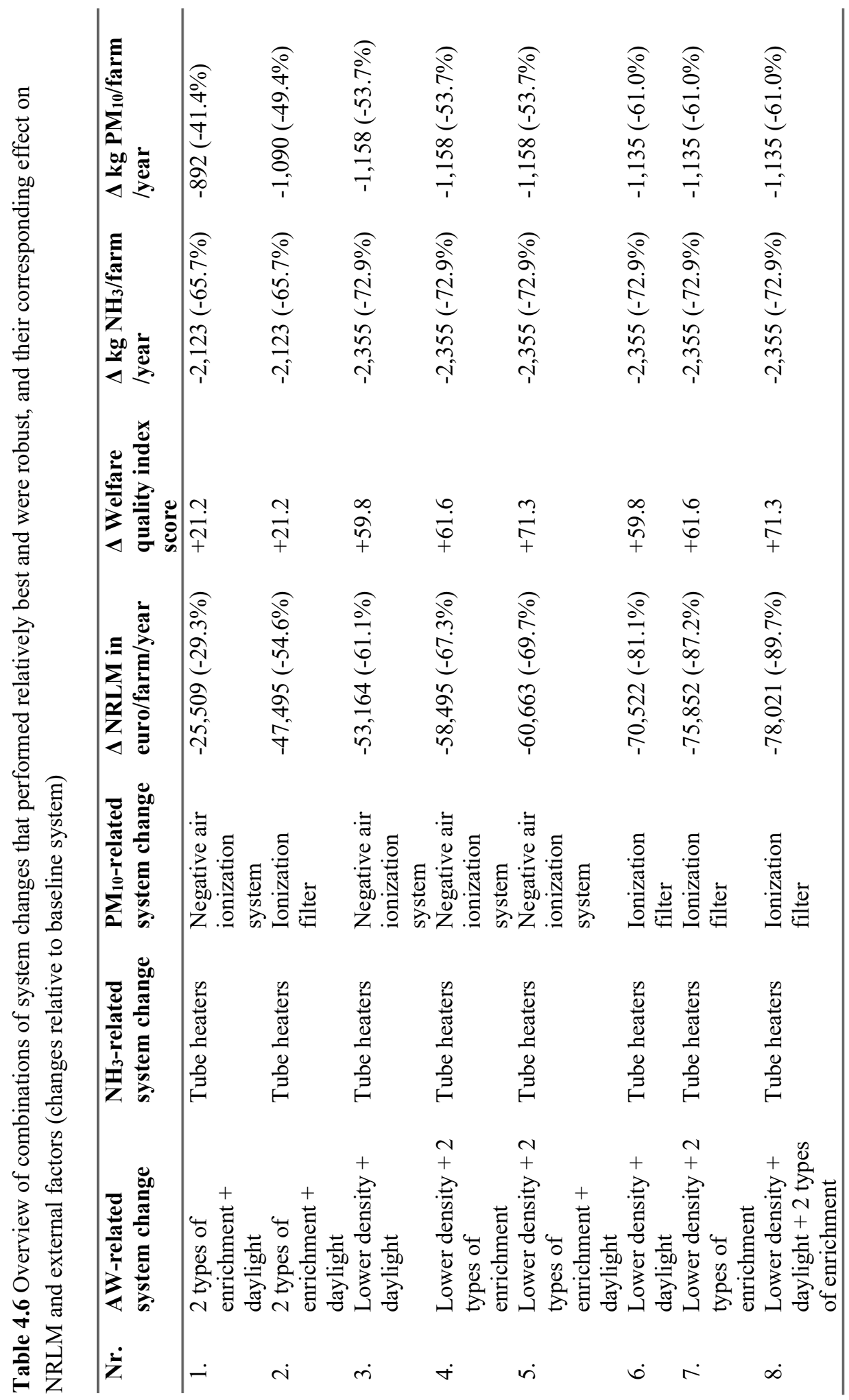


required. When comparing the second combination with the first combination, a further reduction in $\mathrm{PM}_{10}$ emissions was achieved by replacing 'negative air ionization system' by an 'ionization filter' (-49.4\% vs. $-41.4 \%)$. However, this replacement resulted in a relatively large decrease in NRLM (-54.6\% vs. $-29.3 \%)$. Therefore, a higher price premium (8.9 eurocents/broiler) or subsidy (569.3 thousand euros) was required to compensate for this decrease in NRLM. When comparing the fifth combination with the first combination, the system change 'lower density' (from $38 \mathrm{~kg} / \mathrm{m}^{2}$ to $30 \mathrm{~kg} / \mathrm{m}^{2}$ ) was included on top of the system changes imposed in the first combination. Adding this system change lowered both $\mathrm{PM}_{10}$ emissions and $\mathrm{NH}_{3}$ emissions. Furthermore, this system change improved the level of AW. However, this system change caused a relatively large decrease in NRLM (-69.7\% vs. -29.3\%). Therefore, a substantial higher price premium (14.4 eurocents/broiler) or subsidy (767.2 thousand euros) was required to compensate for the decrease in NRLM. The eighth combination included all three AW-related system changes, 'tube heaters' and an 'ionization filter'. The combination mitigated the external factors the most and resulted in the largest decrease in NRLM (-89.7\%), compared to the other best performing and robust combinations. A relatively high price premium (18.5 eurocents/broiler) or subsidy ( 958 thousand euros) was required to compensate for the decrease in NRLM.

\subsubsection{Sensitivity analysis}

A sensitivity analysis was carried out to test the sensitivity of the performance scores of the best performing and robust combinations (Table 4.5) to changes in feed price and producer price. An overview of the performance scores per scenario is provided in Appendix 4D. Figure 4.3 shows the performance score of the best performing and robust combinations per scenario. Results show that a one standard deviation increase in feed price only slightly affected the performance score of these combinations. For instance, the performance score of the second combination, which contained the system changes ' 2 types of enrichment + daylight', 'tube heaters' and 'ionization filter', decreased from 0.95 to 0.94 . This finding can be explained by the fact that a higher amount of feed is required when rearing broilers at higher densities (floor surface area assumed to be fixed). Therefore, combinations that did not include the system change 'lower density' were more responsive to an increase in feed price. A one standard deviation increase in the producer price did not or slightly improved the performance score of combinations that did not include the system change 'lower density' (e.g. the first combination in Figure 4.3). The performance score of combinations that included the system change 'lower density' decreased. For instance, the sixth 


\section{Chapter 4}

combination included the system changes 'lower density + daylight', 'tube heaters' and 'ionization filter'. The performance score of this system change decreased from 0.94 to 0.91 . This finding can be explained by the fact that more revenues are 'foregone' in case of higher producer prices, when lowering the stocking density (floor surface area assumed to be fixed).

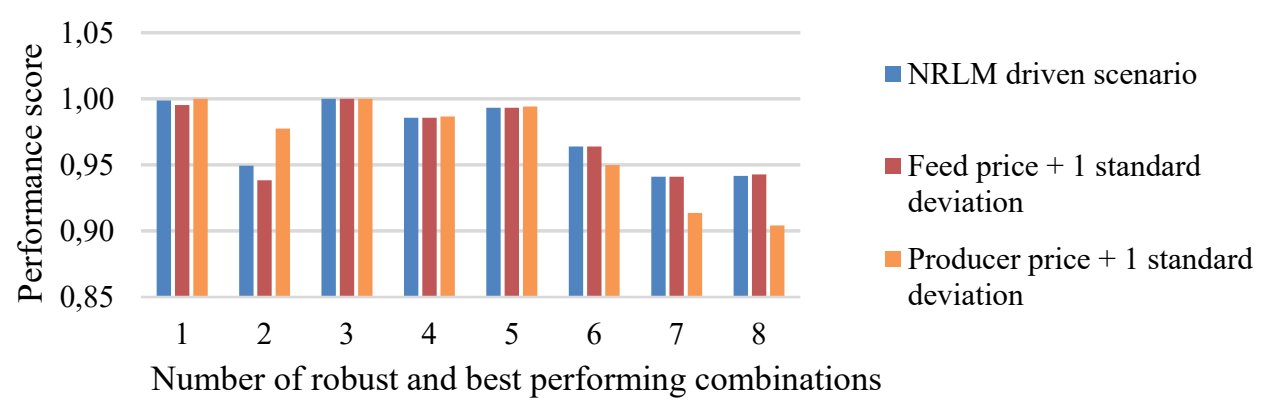

Figure 4.3 Performance score of the best performing and robust combinations in the NRLM driven scenario (see Table 4.6), and in case of a one standard deviation increase in the feed price and producer price

\subsection{Discussion}

This paper aimed to explore the combinations of system changes that were the best in terms of NRLM and external factors, and were robust to changes in the relative importance society places in these external factors. The external factors $\mathrm{AW}, \mathrm{NH}_{3}$ emissions and $\mathrm{PM}_{10}$ emissions were chosen in this study. The results show that 8 out of 70 combinations performed well and were robust to potential changes in society's expectations relating to these external factors. All combinations that were robust and performed well included system changes on $\mathrm{AW}, \mathrm{NH}_{3}$ emissions and $\mathrm{PM}_{10}$ emissions. These combinations contained two or more of the following AWrelated system changes: 'lower density' (from $38 \mathrm{~kg} / \mathrm{m}^{2}$ to $30 \mathrm{~kg} / \mathrm{m}^{2}$ ), '2 types of enrichment' and/or 'daylight'. In line with our findings, Vissers et al. (2021c) show that these system changes improve AW in a cost-efficient manner. The system change 'lower density' resulted in a relatively large decrease in NRLM compared to the system changes ' 2 types of enrichment' and/or 'daylight'. This finding is in line with Verspecht et al. (2011), and can be explained by the 'foregone' revenues when rearing broilers at a lower density (floor surface area assumed to be fixed). The results show that the system change 'lower density' not only improved AW, but also lowered $\mathrm{NH}_{3}$ and $\mathrm{PM}_{10}$ emissions at farm level. The latter finding can be explained by the lower number of broilers reared in the poultry house when lowering the stocking density. Hence, the system change 'lower density', caused 
synergy by mitigating multiple external factors ( $\mathrm{AW}, \mathrm{NH}_{3}$ and $\mathrm{PM}_{10}$ emissions). However, this system change resulted in a relatively large decrease in NRLM compared to the other two AW-related system changes.

Results show that the 8 leading combinations included the system changes 'negative air ionization system' or 'ionization filter' for $\mathrm{PM}_{10}$ emission abatement. Cambra-López et al. (2009) found that ionization techniques are more efficient in PM removal compared to conventional technologies (filtration and adsorption). Our study shows that these techniques score highly in terms of their contribution to reducing $\mathrm{PM}_{10}$ emissions with a relatively small decrease in NRLM. Results show that the leading combinations included 'tube heaters' for $\mathrm{NH}_{3}$ emission abatement. Tube heaters contribute to a lower litter moisture content by reducing the humidity in the broiler house (Dutch Ministry of Infrastructure and Water Management, 2018). The litter moisture content is also affected by other factors, such as the bedding material and the management practices applied by the farmer (Van Harn et al., 2012; Wood \& Van Heyst, 2016). Therefore, the $\mathrm{NH}_{3}$ reduction efficiency of tube heaters may be affected by these factors. End-of-pipe techniques, such as chemical air scrubbers, reduce $\mathrm{NH}_{3}$ emissions from animal houses by treating exhaust air (Melse et al., 2006). Chemical air scrubbers can achieve a reduction efficiency up to nearly 100\% (Melse \& Ogink, 2005). However, knowledge is required for the proper operation and maintenance of chemical air scrubbers. Lack of knowledge may greatly impact the efficiency (Wood \& Van Heyst, 2016). In our study, combinations that included a chemical air scrubber performed worst, i.e. led to a relatively large decrease in NRLM. This finding can be explained by the fact that the investment costs and operational costs of scrubber systems are relatively high compared to other $\mathrm{NH}_{3}$ abatement techniques (Melse et al., 2006). According to Dutch regulations, air scrubbers applied in animal houses should treat the entire exhaust air flow and meet the required minimum removal efficiency. However, as the maximum airflow rate only occurs for a short period of time, most of the time these scrubbers are oversized and underloaded. Melse et al. (2006) found that by combining an air scrubber with air bypass vents, a significant reduction of the investment and operational costs can be achieved while the $\mathrm{NH}_{3}$ emission rate only slightly increases. Hence, this technique can improve the income-efficiency of air scrubbing systems considerably. Since the investment costs and operational costs of this technique were lacking, we did not consider it in our analysis. Further research is required to assess the effect of an air scrubbers with bypass vents on investment costs and operational costs. 


\section{Chapter 4}

The calculation of the NRLM and external factors had some data and model limitations, which affected the performance score of the combinations. As a deterministic model was used to calculate the NRLM, the sensitivity of NRLM to price fluctuations was not considered. To address this issue, a sensitivity analysis was carried out to test the effect of an increase in feed price and producer price by one standard deviation on the performance scores. The results show that the performance score of nearly all robust and best performing combinations was only marginally affected by an increase in feed prices. In the case of an increase in the producer price, most robust and best performing combinations that included the system change 'lower density' performed slightly worse compared to the default situation. Gocsik et al. (2013) show that there is a moderate positive correlation between the feed price and producer price. Since the correlation between the feed price and producer price is not taken into account, the effect of an increase in these prices on the performance score is most likely overestimated. Data on the effect of AW-related system changes (2 types of enrichment, daylight, lower density) on $\mathrm{NH}_{3}$ and $\mathrm{PM}_{10}$ emissions were lacking. Vissers et al. (2021c) show that these system changes affect $\mathrm{NH}_{3}$ and/or $\mathrm{PM}_{10}$ emissions. This shortcoming implies that the performance score of combinations that include these system changes is most likely overestimated. However, as these system changes were applied in all robust and best performing combinations, differences between these combinations are most likely small.

The EU has recently agreed upon goals to improve the welfare of farmed animals and to mitigate the environmental burden associated with intensive livestock production systems in the next ten years (European Commission, 2020). The insights obtained from our study support the development of broiler production systems that satisfy these goals. First, our study supports the design of future broiler production systems by showing the combinations of system changes that performed relatively best and were robust to changes in society's expectations regarding AW and environmental impacts. Second, our study identifies system changes on $\mathrm{NH}_{3}$ and $\mathrm{PM}_{10}$ emissions that are associated with a relatively small decrease in the NRLM. This insight is particularly relevant for EU countries that do not comply with national emission ceilings on $\mathrm{NH}_{3}$ emissions, such as the Netherlands (European Environment Agency, 2019). Third, our study provides insights for determining the minimum price premium needed to get support for the system among the farmers. The extent to which the increase in production costs can be compensated by a higher producer price ultimately depends on consumers' 
willingness to pay for more sustainable production. The Eurobarometer (2016) shows that there is a willingness to pay for more AW-friendly products among EU consumers; however, further research is required to assess consumers' willingness to pay for products that are more AW-friendly and environmentally-friendly compared to conventional products.

\subsection{Conclusion}

This paper aimed to explore combinations of system changes that perform relatively best in terms of farm income, $\mathrm{AW}$ and emissions of $\mathrm{NH}_{3}$ and $\mathrm{PM}_{10}$, and are robust to changes in society's expectations regarding AW and environmental impacts. The findings from this paper indicate that there is a potential to make changes to the current production system that addresses $\mathrm{AW}, \mathrm{NH}_{3}$ emissions and $\mathrm{PM}_{10}$ emissions in an income-efficient manner. We conclude that the best performing and robust combinations included two or more of the following AWrelated system changes: 'lower density', '2 types of enrichment' and/or 'daylight'. Furthermore, these combinations included 'tube heaters' to reduce $\mathrm{NH}_{3}$ emissions and 'negative air ionization system' or an 'ionization filter' to reduce $\mathrm{PM}_{10}$ emissions. The price premiums that were required to compensate for the decrease in net return to labor and management due to implementation of the system changes ranged between 4.8 and 18.5 eurocents/broiler. The 'best performing and robust' combination that required the lowest price premium included ' 2 types of enrichment + daylight', 'tube heaters' and a 'negative air ionization system'. The 'best performing and robust' combination that required the largest price premium included all three AW-related system changes, 'tube heater' and an 'ionization filter'. To test the robustness of the results, future research should focus on measuring the potential environmental benefits of changes made to the Dutch broiler production system that are primarily focused on improving AW. Future research could apply this approach to other livestock production systems to assess the potential for improving the sustainability of livestock production systems more widely.

\section{Acknowledgements}

We gratefully acknowledge the experts for participating in the expert knowledge elicitation. This work was financially supported by the Food Pro-tec-ts project. This project is carried out within the framework of the INTERREG V A program "Deutschland-Nederland" and is co-financed by the European Regional Development Fund (ERDF) and the Dutch Ministry of Economic Affairs and Climate Change, the Ministry of Economic Affairs, Innovation, Digitalization and 


\section{Chapter 4}

Energy of North Rhine-Westphalia and the provinces of Gelderland, Limburg and North Brabant. It is accompanied by the program management at the Euregio Rhein-Waal.

\section{Appendix}

\section{Appendix 4A. Selected experts}

The following criteria were considered when selecting experts for 1) identification of the external factors that are key drivers in the development of Dutch broiler production and 2) identification of the system changes that are likely to be implemented in the baseline system in the next ten years:

- Substantive knowledge about broiler welfare, ammonia emissions and/or particulate matter emissions originating from broiler production systems.

- Substantive knowledge about the Dutch broiler sector.

Based on these criteria, the following experts were consulted:

- Jan van Harn, researcher at Wageningen Livestock Research. Jan van Harn is expert in poultry nutrition.

- Hilko Ellen, researcher at Wageningen Livestock Research. Hilko Ellen is expert in poultry housing and agricultural engineering.

- Albert Winkel, researcher at Wageningen Livestock Research. Albert Winkel is expert in particulate matter emissions and poultry housing.

- Rick van Emous, researcher at Wageningen Livestock Research. Rick van Emous is expert in poultry nutrition.

- Peter Groot Koerkamp, professor at the farm technology group, Wageningen University. Peter Groot Koerkamp is expert in agricultural engineering and poultry farming.

- Ingrid de Jong, researcher at Wageningen Livestock Research. Ingrid de Jong is expert in poultry welfare.

Appendix 4B. Substantiation of the system changes selected by the experts 2 types of enrichment and daylight: The experts expect that broiler welfare improvements will be implemented in the new Dutch retail standard system, as societal pressure to improve broiler welfare is increasing. Two broiler welfare improvements are already applied in the baseline system, i.e. a slower-growing breed and a reduction of the stocking density (from $42 \mathrm{~kg} / \mathrm{m}^{2}$ to $38 \mathrm{~kg} / \mathrm{m}^{2}$ ) (Vissers et al., 2021c). The experts expect that more enrichment and daylight will be provided in this system, as these system changes improve broiler welfare and are 
associated with a relatively small increase in production costs compared to other animal welfare improvements (Vissers et al., 2021c).

Stocking density: the experts expect that the stocking density will be reduced in the baseline system, as stocking density is one of the main contributors to animal welfare (Gocsik et al., 2016a). Therefore, a relatively large improvement in broiler welfare can be achieved by lowering the stocking density. However, a reduction in stocking density has a relatively large negative impact on farm profitability (Verspecht et al., 2011). Therefore, experts think that it is less likely that this system change will be implemented in the baseline system, compared to the system changes enrichment and daylight.

Tube heaters: In the next ten years, farmers have to comply with more stringent ammonia emission legislation (Dutch Ministry of Infrastructure and Water Management, 2017). The experts expect that tube heaters will be used more widely in Dutch broiler houses as this technique is characterized by a relatively high ammonia reduction efficiency $(-82 \%)$, while the investment and operational costs of this technique are relatively low compared to other $\mathrm{NH}_{3}$ abatement systems (Blanken et al., 2020). As tube heaters are commercially available in the Netherlands since 2017 (Expertise Centre Infomil, 2017), this technique is not (yet) widely used by Dutch broiler farmers.

Chemical air scrubber: very high reductions of ammonia emission (up to nearly $100 \%$ ) can be achieved with chemical air scrubbers (Melse, 2009). Therefore, chemical air scrubbers may be applied for situations with very stringent ammonia emissions limits. As the investment and operational costs of air scrubbing techniques are high compared to other ammonia abatement techniques (Melse, 2009), experts do not expect that this technique will be implemented widely in Dutch broiler houses.

TerraSea system: as a chemical air scrubber is applied in the TerraSea system, a reduction in ammonia emissions up to $90 \%$ can be achieved (Ellen et al., 2014b). Therefore, this system is also suitable for situations with very stringent ammonia emissions limits. Geothermal energy is used in the TerraSea system, resulting in low energy costs (Ellen et al., 2014b). A disadvantage of this system is that sufficient knowledge is required for proper operation and maintenance (Ellen et al., 2014b). Lack of knowledge strongly affects the performance of this system. Furthermore, the investment costs of the TerraSea system are relatively high 


\section{Chapter 4}

(Blanken et al., 2020). Therefore, experts do not expect that that this technique will be implemented widely in Dutch broiler production systems.

Negative air ionization system: In the next ten years, Dutch broiler farmers have to comply with more stringent particulate matter emission legislation (Dutch Ministry of Infrastructure and Water Management, 2017). The negative air ionization was selected for the following three reasons. First, this system proved to be a practical and effective technique for particulate matter reduction (Cambra-López et al., 2009). Second, this system is characterized by low investment and operational costs compared to other particulate matter abatement systems (Blanken et al., 2020). Third, Dutch farmers can apply for a subsidy for which $40 \%$ of the investment costs of ionization systems are reimbursed (Netherlands Enterprise Agency, 2020b). Therefore, it is very likely that this system will be increasingly used in Dutch broiler houses in the next years.

Ionization filter: The ionization system was selected as this system has a relatively high particulate matter removal efficiency $(-57 \%)$ compared to other particulate matter abatement techniques (Expertise Centre Infomil, 2019b). Therefore, this system may be applied for situations with very stringent particulate matter emissions limits. Furthermore, the energy costs of this system are relatively low (Blanken et al., 2020). However, the investment costs of the ionization filter are relatively high compared to indoor particulate matter abatement techniques (Blanken et al., 2020). Currently, there is no subsidy scheme to cover the investment costs of this technique. Therefore, it is less likely that this system will be implemented widely in the next ten years.

Heat exchanger $31 \% \mathrm{PM}_{10}$ reduction: heat exchangers with $13 \% \mathrm{PM}_{10}$ reduction are widely used in Dutch broiler houses (H.H. Ellen, personal communication, 2020). In the study of Bokkers et al. (2010), Dutch broiler farmers indicated that they were satisfied with the heat exchanger, as it increased job satisfaction, improved the climate conditions in the broiler house and improved litter quality. As many Dutch broiler farmers are already familiar with this system, a heat exchanger with $31 \% \mathrm{PM}_{10}$ reduction may be implemented more widely in the next ten years. However, the investment costs of this system are relatively high compared to indoor PM abatement techniques (Blanken et al., 2020). Furthermore, there is no subsidy program available for this technique. Therefore, the likelihood that this system will be implemented widely in Dutch broiler houses is low. 
Appendix 4C. Formulas used to calculate price premium and subsidy

Formula used for calculation of the price premium

The following formulas were used to calculate the price premium required to compensate for the decrease in net return to labor and management (NRLM) associated with a combination of system changes:

$N_{x}=R_{x}-\left(C_{x}-L_{x}\right)$

$\Delta N=N_{y}-N_{x}$

$P=\frac{\Delta N}{(s * a * r)}$

Where: $N_{x}=$ NRLM generated in production system $x$ that includes a combination of system changes (expressed in euro per farm per year), $R=$ total revenues generated in production system $x, C=$ total costs generated in production system $x, L=$ labor costs generated in production system $x, N_{y}=$ NRLM generated in the baseline broiler production system, $\Delta N=$ change in NRLM in euro per farm per year, $P=$ price premium, $s=$ floor surface area in $\mathrm{m}^{2}, a=$ number of animals per $\mathrm{m}^{2}, \mathrm{r}=$ number of rounds per year

Formula used for calculation of subsidy

The total subsidy required to compensate for the decrease in NRLM was calculated using the net present value method (Barry \& Ellinger, 2012):

$N P V(i, T)=\sum_{t=0}^{T} \frac{\Delta N}{(1+i)^{t}}$

Where: $N P V=$ net present value, $i=$ discount rate, $T=$ total number of periods

Appendix $4 D$. Overview of performance score per combination

An overview of performance score per combination can be found online at:

https://doi.org/10.1016/j.agsy.2021.103217 


\section{Chapter 4}

\section{References}

Agrimatie. (2015). Voorzieningsbalansen. Retrieved from https://www.agrimatie.nl/VoorzieningsBalansen.aspx

Agrimatie. (2018). Agrarische prijzen. Retrieved from https://www.agrimatie.nl/Prijzen.aspx?ID=15125

Albert Heijn. (2018). AH hele kip. Retrieved from https://www.ah.nl/producten/product/wi39978/ah-hele-kip

Bailie, C. L., Ball, M. E. E., \& O'Connell, N. E. (2013). Influence of the provision of natural light and straw bales on activity levels and leg health in commercial broiler chickens. Animal, 7(4), 618-626. doi:https://doi.org/10.1017/S1751731112002108

Barry, P. J., \& Ellinger, P. N. (2012). Financial Management in Agriculture: Pearson.

Baumol, W. J., Panzar, J., \& Willig, R. (1983). Contestable markets: an uprising in the theory of industry structure. American Economic Review, 73(3), 491496. doi:www.jstor.org/stable/1808145

Bessei, W. (2006). Welfare of broilers: a review. World's Poultry Science Journal, 62(3), 455-466. doi:https://doi.org/10.1017/S0043933906001085

Better Chicken Commitment. (2020). Better Chicken Commitment. Retrieved from https://betterchickencommitment.com/

Blanken, K., De Buisonje, F., Evers, A. G., Ouweltjes, W., Verkaik, J. C., Vermeij, I., \& Wemmenhove, H. (2019). KWIN 2019-2020: Wageningen University \& Research.

Blanken, K., De Buisonje, F., Everts, A., Holster, H., Ouweltjes, W., Verkaik, J. C., ... Wemmenhove, H. (2020). KWIN 2020-2021.

Bokkers, E. A. M., \& De Boer, I. J. M. (2009). Economic, ecological, and social performance of conventional and organic broiler production in the Netherlands. British Poultry Science, 50(5), 546-557. doi:https://doi.org/10.1080/00071660903140999

Bokkers, E. A. M., Van Zanten, H. H. E., \& Van den Brand, H. (2010). Field study on effects of a heat exchanger on broiler performance, energy use, and calculated carbon dioxide emission at commercial broiler farms, and the experiences of farmers using a heat exchanger. Poultry science, $89(12)$, 2743-2750. doi:https://doi.org/10.3382/ps.2010-00902

Bokma-Bakker, M. H., Wiegel, J., Holstege, M. M. C., Kluivers-Poodt, M., De Lauwere, C. C., \& Bouwstra, R. J. (2017). Onderzoek naar kritische succesfactoren voor een laag antibioticumgebruik bij vleeskuikens: rapport van het project Kritische Succesfactoren Pluimvee (KSF Pluimvee). In Livestock Research rapport, 1570-8616 ; 1065A. Retrieved from https://doi.org/10.18174/427330

Bracke, M. B. M., Koene, P., Estevéz, I., Butterworth, A., \& de Jong, I. C. (2019). Broiler welfare trade-off: A semi-quantitative welfare assessment for optimised welfare improvement based on an expert survey. PLoS One, 14(10), e0222955. doi:https://doi.org/10.1371/journal.pone.0222955 
Broom, D. M. (2017). Animal Welfare in the European Union. Retrieved from http://www.europarl.europa.eu/RegData/etudes/STUD/2017/583114/IPOL STU(2017)583114 EN.pdf

Buurma, J., Hennen, W., \& Verwaart, T. (2017). How social unrest started innovations in a food supply chain. Journal of Artificial Societies and Social Simulation, 20(1). doi:https://doi.org/10.18564/jasss.3350

Calhoun, C. J., \& Oxford University, P. (2002). Dictionary of the social sciences. In. Retrieved from https://www-oxfordreferencecom.ezproxy.library.wur.nl/view/10.1093/acref/9780195123715.001.0001/ acref-9780195123715

Calvet, S., Van den Weghe, H., Kosch, R., \& Estellés, F. (2009). The influence of the lighting program on broiler activity and dust production. Poultry Science, 88(12), 2504-2511. doi:https://doi.org/10.3382/ps.2009-00255

Cambra-López, M., Aarnink, A. J. A., Zhao, Y., Calvet, S., \& Torres, A. G. (2010). Airborne particulate matter from livestock production systems: A review of an air pollution problem. Environmental Pollution, 158(1), 1-17. doi:https://doi.org/10.1016/j.envpol.2009.07.011

Cambra-López, M., Winkel, A., Van Harn, J., Ogink, N. W. M., \& Aarnink, A. J. A. (2009). Ionization for reducing particulate matter emissions from poultry houses. Transactions of the ASABE, 52(5), 1757-1771. doi:https://doi.org/10.13031/2013.29138

Castellini, C., Boggia, A., Cortina, C., Dal Bosco, A., Paolotti, L., Novelli, E., \& Mugnai, C. (2012). A multicriteria approach for measuring the sustainability of different poultry production systems. Journal of Cleaner Production, 37, 192-201. doi:https://doi.org/10.1016/j.jclepro.2012.07.006

CBS. (2018). Consumentenprijsindex; 2015=100. Retrieved from: http://statline.cbs.nl/Statweb/publication/?DM=SLNL\&PA=83131NED\& $\mathrm{D} 1=4 \& \mathrm{D} 2=12 \& \mathrm{D} 3=220 \% 2 \mathrm{c} 233 \% 2 \mathrm{c} 246 \% 2 \mathrm{c} 259 \% 2 \mathrm{c} 272 \% 2 \mathrm{c} 285 \& \mathrm{HDR}=$ $\mathrm{T} \& \mathrm{STB}=\mathrm{G} 2 \% 2 \mathrm{cG} 1 \& \mathrm{VW}=\mathrm{T}$

Cherchye, L., Moesen, W., Rogge, N., \& Van Puyenbroeck, T. (2007). An introduction to 'benefit of the doubt' composite indicators. Social Indicators Research, 82(1), 111-145. doi:https://doi.org/10.1007/s11205006-9029-7

Dawkins, M. S. (2017). Animal welfare and efficient farming: is conflict inevitable? Animal Production Science, 57(2), 201-208. doi:https://doi.org/10.1071/AN15383

De Jong, I. C., \& Gunnink, H. (2019). Effects of a commercial broiler enrichment programme with or without natural light on behaviour and other welfare indicators. animal, 13(2), 384-391. doi:10.1017/S1751731118001805

De Jong, I. C., Gunnink, H., \& Hindle, V. A. (2015). Implementation of the Welfare Quality broiler assessment protocol-final report: overview of outcome-based measurement of broiler welfare and a general discussion on the Welfare Quality broiler assessment protocol. Retrieved from https://library.wur.nl/WebQuery/wurpubs/486781 


\section{Chapter 4}

De Jonge, J., \& Van Trijp, H. C. M. (2013). Meeting heterogeneity in consumer demand for animal welfare: A reflection on existing knowledge and implications for the meat sector. Journal of Agricultural and Environmental Ethics, 26(3), 629-661. doi:https://doi.org/10.1007/s10806012-9426-7

De Passillé, A. M., \& Rushen, J. (2005). Food safety and environmental issues in animal welfare. Revue scientifique et technique-Office international des épizooties, 24(2), 757.

Dixon, L. M. (2020). Slow and steady wins the race: The behaviour and welfare of commercial faster growing broiler breeds compared to a commercial slower growing breed. PLoS One, 15(4), e0231006. doi:https://doi.org/10.1371/journal.pone.0231006

Dunlop, M. W., Blackall, P. J., \& Stuetz, R. M. (2016). Odour emissions from poultry litter - A review litter properties, odour formation and odorant emissions from porous materials. Journal of Environmental Management, 177, 306-319. doi:https://doi.org/10.1016/j.jenvman.2016.04.009

Dutch Ministry of Infrastructure and Water Management. Besluit emissiearme huisvesting, W14.15.0152 C.F.R. (2017).

Dutch Ministry of Infrastructure and Water Management. (2018). Tube heaters in poultry houses. The Hague Retrieved from https://www.infomil.nl/onderwerpen/landbouw/emissiearmestalsystemen/stalbeschrijvingen/\#hc0306243-8038-4a12-a383a961f4b226f8.

Dutch Ministry of Infrastructure and Water Management. (2019). Clean air agreement. Rijksoverheid Retrieved from https://www.rijksoverheid.nl/documenten/convenanten/2020/01/13/bijlage1-schone-lucht-akkoord.

Dutch Ministry of Infrastructure and Water Management. (2020). Kengetallen Leefomgeving. Retrieved from https://www.rwseconomie.nl/kengetallen/kengetallen-leefomgeving.

Dutch Ministry of Instrastructure and Water Management. (2020). Rekenmodel Vee-combistof. Retrieved from https://www.infomil.nl/onderwerpen/landbouw/emissiearmestalsystemen/rekenmodel-vee-combistof/

Dutch National Institute for Public Health and Environment. (2017). Model to calculate emissions from animal housing. Retrieved from https://www.aerius.nl/nl/factsheets/emissieberekening-stallen/17-03-2017.

EFSA. (2010). Scientific Opinion on the influence of genetic parameters on the welfare and the resistance to stress of commercial broilers. EFSA Journal, 8(7), 1666. doi:https://doi.org/10.2903/j.efsa.2010.1666

EFSA. (2014). Guidance on Expert Knowledge Elicitation in Food and Feed Safety Risk Assessment. EFSA Journal, 12(6), 278. doi:https://doi.org/10.2903/j.efsa.2014.3734 
Ellen, H. H., Jansen, J., Smit, A., \& Vermeij, I. (2014a). Side benefits from sustainable housing systems. Retrieved from https://edepot.wur.nl/302614

Ellen, H. H., Jansen, J., Smit, A., \& Vermeij, I. (2014b). TerraSea voor vleeskuikens-Nevenvoordelen duurzame stalconcepten.

Eurobarometer. (2005). Attitudes of consumers towards the welfare of farmed animals. Special Eurobarometer, 229, 45-46.

Eurobarometer. (2013). Attitudes of Europeans towards air quality. Retrieved from https://ec.europa.eu/commfrontoffice/publicopinion/flash/fl 360 en.pdf

Eurobarometer. (2015). Attitudes of Europeans towards biodiversity. Retrieved from https://op.europa.eu/nl/publication-detail/-/publication/50bfl efd720b-11 e9-9f05-01aa75ed71a1/language-en/format-PDF

Eurobarometer. (2016). Attitudes of Europeans towards animal welfare. Retrieved from

https://ec.europa.eu/commfrontoffice/publicopinion/index.cfm/ResultDoc/ download/DocumentKy/71348

Eurobarometer. (2017). Attitudes of European citizens towards the environment. Retrieved from

https://ec.europa.eu/public opinion/archives/ebs/ebs 416 en.pdf.

Eurobarometer. (2019). Food Safety in the EU. European Commission Retrieved from

https://www.efsa.europa.eu/sites/default/files/corporate publications/files/ Eurobarometer2019 Food-safety-in-the-EU Full-report.pdf.

European Commission. (2020). Farm to Fork Strategy. Retrieved from https://ec.europa.eu/food/sites/food/files/safety/docs/f2f_actionplan 2020 strategy-info en.pdf

European Council Directive. Directive 98/58/EC of 20 July 1998 concerning the protection of animals kept for farming purposes, 98/58/EC C.F.R. (1998).

European Council Directive. (2000). The Welfare of Chickens Kept for Meat production (broilers). Retrieved from

https://ec.europa.eu/food/sites/food/files/safety/docs/scicom_scah_out39 en.pdf

European Council Directive. Directive 2001/81/EC of the European Parliament and of the council of 23 October 2001 on national emission ceilings or certain atmospheric pollutants, (2001).

European Council Directive. Directive 2003/99/EC of the European Parliament and of the Council of 17 November 2003 on the monitoring of zoonoses and zoonotic agents, (2003).

European Council Directive. Directive 2007/43/EC of 28 June 2007 laying down minimum rules for the protection of chickens kept for meat production, 2007/43/EC C.F.R. (2007).

European Council Directive. Directive 2008/120/EC of 18 December 2008 laying down minimum standards for the protection of pigs, (2008).

European Council Directive. Regulation (EC) No 1069/2009 of the European Parliament and of the Council of 21 October 2009 laying down health rules 


\section{Chapter 4}

as regards animal by-products and derived products not intended for human consumption and repealing Regulation (EC), 1069/2009 C.F.R. (2009).

European Council Directive. Directive 2016/2284 of the European Parliament and of the Council of 14 December 2016 on the reduction of national emissions of certain atmospheric pollutants, 2016/2284 C.F.R. (2016).

European Environment Agency. (2019). Ammonia emissions from agriculture continue to pose problems for Europe. Retrieved from https://www.eea.europa.eu/highlights/ammonia-emissions-fromagriculture-continue.

European Environment Agency. (2020). National emissions reported to the Convention on Long-range Transboundary Air Pollution (LRTAP Convention). Retrieved from: https://www.eea.europa.eu/data-andmaps/data/national-emissions-reported-to-the-convention-on-long-rangetransboundary-air-pollution-lrtap-convention-14

Expertise Centre Infomil. (2017). Stal met buizenverwarming. Retrieved from https://www.infomil.nl/publish/pages/130041/bwl 2017 01 v2.pdf.

Expertise Centre Infomil. (2019a). Emission factors per animal - broilers.

Retrieved from

https://www.infomil.nl/onderwerpen/landbouw/stalsystemen/emissiefactor en-per/map-staltypen/5-diercategorie/

Expertise Centre Infomil. (2019b). Emission factors per animal - particulate matter. Retrieved from

https://www.infomil.nl/onderwerpen/landbouw/stalsystemen/emissiefactor en-per/map-staltypen/7-additionele/

FAPRI. (2019). FAPRI Elasticity Database. Retrieved from: http://www.fapri.iastate.edu/tools/elasticity.aspx

Gallet, C. A. (2010). Meat meets meta: a quantitative review of the price elasticity of meat. American Journal of Agricultural Economics, 92(1), 258-272. doi:https://doi.org/10.1093/ajae/aap008

Gocsik, É., Brooshooft, S. D., De Jong, I. C., \& Saatkamp, H. W. (2016a). Costefficiency of animal welfare in broiler production systems: A pilot study using the Welfare Quality ${ }^{\circledR}$ assessment protocol. Agricultural Systems, 146, 55-69. doi:https://doi.org/10.1016/j.agsy.2016.04.001

Gocsik, É., Oude Lansink, A. G. J. M., \& Saatkamp, H. W. (2013). Mid-term financial impact of animal welfare improvements in Dutch broiler production. Poultry Science, 92(12), 3314-3329. doi:https://doi.org/10.3382/ps.2013-03221

Gocsik, É., Van der Lans, I. A., Oude Lansink, A. G. J. M., \& Saatkamp, H. W. (2015). Willingness of Dutch broiler and pig farmers to convert to production systems with improved welfare. Animal Welfare, 24(2), 211222. doi:https://doi.org/10.7120/09627286.24.2.211

Gocsik, É., Van der Lans, I. A., Oude Lansink, A. G. J. M., \& Saatkamp, H. W. (2016b). Elicitation of preferences of Dutch broiler and pig farmers to 
support decision making on animal welfare. NJAS - Wageningen Journal of Life Sciences, 76, 75-86. doi:https://doi.org/10.1016/j.njas.2015.11.006

Groot Koerkamp, P. W. G., Middelkoop, J. H., \& Evers, E. (2000).

Ammoniakemissie vleeskuikenstallen toegenomen. Pluimveehouderij, 30, $10-11$.

Homidan, A. A., Robertson, J. F., \& Petchey, A. M. (2003). Review of the effect of ammonia and dust concentrations on broiler performance. World's Poultry Science Journal, 59(3), 340-349. doi:https://doi.org/10.1079/WPS20030021

Kjaer, J. B., Su, G., Nielsen, B. L., \& Sørensen, P. (2006). Foot pad dermatitis and hock burn in broiler chickens and degree of inheritance. Poultry Science, 85(8), 1342-1348. doi:https://doi.org/10.1093/ps/85.8.1342

Knowles, T. G., Kestin, S. C., Haslam, S. M., Brown, S. N., Green, L. E., Butterworth, A., .. . Nicol, C. J. (2008). Leg disorders in broiler chickens: prevalence, risk factors and prevention. PLoS One, 3(2), e1545. doi:https://doi.org/10.1371/journal.pone.0001545

Lagerkvist, C. J., Hansson, H., Hess, S., \& Hoffman, R. (2011). Provision of Farm Animal Welfare: Integrating Productivity and Non-Use Values. Applied Economic Perspectives and Policy, 33(4), 484-509. doi:https://doi.org/10.1093/aepp/ppr037

Lebacq, T., Baret, P. V., \& Stilmant, D. (2013). Sustainability indicators for livestock farming. A review. Agronomy for Sustainable Development, 33(2), 311-327. doi:https://doi.org/10.1007/s13593-012-0121-x

Leinonen, I., Williams, A. G., \& Kyriazakis, I. (2014). The effects of welfareenhancing system changes on the environmental impacts of broiler and egg production. Poultry Science, 93(2), 256-266. doi:https://doi.org/10.3382/ps.2013-03252

Leinonen, I., Williams, A. G., Waller, A. H., \& Kyriazakis, I. (2013). Comparing the environmental impacts of alternative protein crops in poultry diets: The consequences of uncertainty. Agricultural Systems, 121, 33-42. doi:10.1016/j.agsy.2013.06.008

Leinonen, I., Williams, A. G., Wiseman, J., Guy, J., \& Kyriazakis, I. (2012). Predicting the environmental impacts of chicken systems in the United Kingdom through a life cycle assessment: Broiler production systems. Poultry Science, 91(1), 8-25. doi:https://doi.org/10.3382/ps.2011-01634

Lusk, J. L., \& McCluskey, J. (2018). Understanding the Impacts of Food Consumer Choice and Food Policy Outcomes. Applied Economic Perspectives and Policy, 40(1), 5-21. doi:https://doi.org/10.1093/aepp/ppx054

Lusk, J. L., \& Norwood, F. B. (2011). Animal Welfare Economics. Applied Economic Perspectives and Policy, 33(4), 463-483. doi:https://doi.org/10.1093/aepp/ppr036

Lusk, J. L., Pruitt, J. R., \& Norwood, F. B. (2006). Consumer Demand for a Ban on Antibiotic Drug Use in Pork Production. American Journal of Agricultural 


\section{Chapter 4}

Economics, 88(4), 1015-1033. doi:https://doi.org/10.1111/j.14678276.2006.00913.x

Meerburg, B., Korevaar, H., Haubenhofer, D., Blom-Zandstra, M., \& Van Keulen, H. (2009). The changing role of agriculture in Dutch society. The Journal of Agricultural Science, 147(5), 511. doi:https://doi.org/10.1017/S0021859609990049

Melse, R. W. (2009). Air treatment techniques for abatement of emissions from intensive livestock production. Retrieved from http://edepot.wur.nl/12452 WorldCat.org database.

Melse, R. W., \& Ogink, N. W. M. (2005). Air scrubbing techniques for ammonia and odor reduction at livestock operations: review of on-farm research in the Netherlands. Transactions of the American Society of Agricultural Engineers, 48(6), 2303-2313.

Melse, R. W., van Wagenberg, A. V., \& Mosquera, J. (2006). Size reduction of ammonia scrubbers for pig and poultry houses: use of conditional bypass vent at high air loading rates. Biosystems Engineering, 95(1), 69-82. doi:https://doi.org/10.1016/i.biosystemseng.2006.05.006

Miele, M., Blokhuis, H. J., Bennett, R., \& Bock, B. (2013). Changes in farming and in stakeholder concern for animal welfare. In Improving farm animal welfare (pp. 19-47): Springer.

Ministry of Agriculture, N. a. F. Q. Regeling Diergeneesmiddelen, (2019).

Namroud, N. F., Shivazad, M., \& Zaghari, M. (2008). Effects of Fortifying Low Crude Protein Diet with Crystalline Amino Acids on Performance, Blood Ammonia Level, and Excreta Characteristics of Broiler Chicks. Poultry Science, 87(11), 2250-2258. doi:https://doi.org/10.3382/ps.2007-00499

Netherlands Enterprise Agency. (2020a). Antibiotic resistance in the livestock industry. Retrieved from https://www.government.nl/topics/antibioticresistance/antibiotic-resistance-in-livestockfarming\#: : text=Less $\% 20$ antibiotic $\% 20$ use $\% 20$ in $\% 20$ the,have $\% 20$ fallen $\%$ 20by $\% 20$ another $\% 2011 \% 25$.

Netherlands Enterprise Agency. (2020b). Investing in innovative techniques in animal husbandry. Retrieved from https://www.rvo.nl/subsidie-enfinancieringswijzer/innovatie-en-verduurzaming-stallen

OECD. (2008). Handbook on constructing composite indicators: methodology and user guide. Retrieved from https://www.oecd.org/sdd/42495745.pdf

Peña Fernández, A., Demmers, T. G. M., Tong, Q., Youssef, A., Norton, T., Vranken, E., \& Berckmans, D. (2019). Real-time modelling of indoor particulate matter concentration in poultry houses using broiler activity and ventilation rate. Biosystems Engineering, 187, 214-225. doi:https://doi.org/10.1016/j.biosystemseng.2019.09.004

Plastina, A., \& Giannakas, K. (2007). Market and welfare effects of GMO introduction in small open economies. AgBioForum, 10(2), 104-123.

R Core team. (2020). R: A language and environment for statistical computing. Vienna, Austria. Retrieved from https://www.R-project.org/ 
Raedts, P. J. M., Garcia, S. C., Chapman, D. F., Edwards, G. R., Lane, N., \& Rawnsley, R. P. (2017). Is systems research addressing the current and future needs of dairy farms? Animal Production Science, 57(7), 1311-1322. doi:https://doi.org/10.1071/AN16647

Reinders, M., Poppe, K. J., Immink, V., Van den Broek, E., Van Horne, P. L. M., \& Hoste, R. (2013). Waardevolle perspectieven voor vlees. Retrieved from Den Haag: https://edepot.wur.nl/296834

Riber, A. B., Van de Weerd, H. A., De Jong, I. C., \& Steenfeldt, S. (2018). Review of environmental enrichment for broiler chickens. Poultry Science, 97(2), 378-396. doi:https://doi.org/10.3382/ps/pex344

Rocchi, L., Paolotti, L., Rosati, A., Boggia, A., \& Castellini, C. (2019). Assessing the sustainability of different poultry production systems: A multicriteria approach. Journal of Cleaner Production, 211, 103-114. doi:https://doiorg.ezproxy.library.wur.n1/10.1016/j.jclepro.2018.11.013

Rodenburg, T. B., \& Koene, P. (2007). The impact of group size on damaging behaviours, aggression, fear and stress in farm animals. Applied Animal Behaviour Science, 103(3-4), 205-214. doi:https://doi.org/10.1016/j.applanim.2006.05.024

Rougoor, C., \& Van der Schans, F. (2019). Vergelijking milieueffecten vleeskuikenconcepten. Retrieved from https://www.pluimveeloket.be/sites/default/files/inline-files/201910\%20CLMrapport-Vergelijking milieueffecten_vleeskuikenconcepten.pdf

Saatkamp, H. W., Vissers, L. S. M., Van Horne, P. L. M., \& De Jong, I. C. (2019). Transition from conventional broiler meat to meat from production concepts with higher animal welfare: experiences from The Netherlands. Animals, 9(8). doi:https://doi.org/10.3390/ani9080483

Saitone, T. L., Sexton, R. J., \& Sumner, D. A. (2015). What Happens When Food Marketers Require Restrictive Farming Practices? American Journal of Agricultural Economics, 97(4), 1021-1043. doi:https://doi.org/10.1093/ajae/aav021

Segerson, K. (2013). When Is Reliance on Voluntary Approaches in Agriculture Likely to Be Effective? Applied Economic Perspectives and Policy, 35(4), 565-592. doi:https://doi.org/10.1093/aepp/ppt030

Sørensen, P., Su, G., \& Kestin, S. C. (2000). Effects of Age and Stocking Density on Leg Weakness in Broiler Chickens. Poultry Science 79(6), 864-870. doi:https://doi.org/10.1093/ps/79.6.864

Stadig, L. (2019). Vleeskuikenconcepten in Nederland. Retrieved from https:/www.pluimveeloket.be/sites/default/files/inline-files/2019-1010\%20Welzijnsvergelijking\%20vleeskuikenconcepten.pdf

Stadig, L. M., Rodenburg, T. B., Ampe, B., Reubens, B., \& Tuyttens, F. A. M. (2017). Effect of free-range access, shelter type and weather conditions on free-range use and welfare of slow-growing broiler chickens. Applied 


\section{Chapter 4}

Animal Behaviour Science, 192, 15-23.

doi:https://doi.org/10.1016/j.applanim.2016.11.008

Swinnen, J., Deconinck, K., Vandemoortele, T., \& Vandeplas, A. (2015). Quality standards, value chains, and international development: economic and political theory. New York: Cambridge University Press.

Tallentire, C. W., Leinonen, I., \& Kyriazakis, I. (2018). Artificial selection for improved energy efficiency is reaching its limits in broiler chickens.

Scientific Reports, 8(1), 1168. doi:10.1038/s41598-018-19231-2

TNO. (2019). Factsheet emissies en depositie van stikstof in Nederland. Retrieved from The Hague:

https://publications.tno.nl/publication/34634850/8Pywsn/TNO-2019emissies.pdf

Tullo, E., Fontana, I., Peña Fernández, A., Vranken, E., Norton, T., Berckmans, D., \& Guarino, M. (2017). Association between environmental predisposing risk factors and leg disorders in broiler chickens. Journal of Animal Science, 95(4), 1512-1520. doi:https://doi.org/10.2527/jas.2016.1257

Van Geijlswijk, I. M., Heederik, D., Mouton, J. W., Wagenaar, J. A., Jacobs, J. H., \& Sanders, P. (2019). Usage of Antibiotics in Agricultural Livestock in the Netherlands in 2018. Retrieved from https://cdn.ipulse.nl/autoriteitdiergeneesmiddelen/userfiles/Publications/2018-defrapport1.pdf

Van Harn, J., Dijkslag, M. A., \& van Krimpen, M. M. (2019). Effect of low protein diets supplemented with free amino acids on growth performance, slaughter yield, litter quality, and footpad lesions of male broilers. Poultry Science, 98(10), 4868-4877. doi:https://doi.org/10.3382/ps/pez229

Van Harn, J. V., Aarnink, A. J. A., Mosquera, J., Van Riel, J. W., \& Ogink, N. W. M. (2012). Effect of bedding material on dust and ammonia emission from broiler houses. Transactions of the ASABE, 55(1), 219-226.

Van Harn, J. V., Ellen, H. H., Van Riel, J. W., \& Huis in 't Veld, J. W. H. (2015). Effect of low emission techniques on mortality rate and footpad dermatitis score of broilers. In. Retrieved from http://edepot.wur.nl/331377

Van Horne, P. L. M. (2017). Competitiveness of the EU poultry meat sector, base year 2015; International comparison of production costs. Retrieved from http://edepot.wur.nl/404949

Van Horne, P. L. M. (2020). Economics of broiler production systems in the Netherlands: economic aspects within the Greenwell sustainability assessment model. Retrieved from Wageningen: https://edepot.wur.nl/518522

Vanhonacker, F., \& Verbeke, W. (2014). Public and Consumer Policies for Higher Welfare Food Products: Challenges and Opportunities. Journal of Agricultural and Environmental Ethics, 27(1), 153-171. doi:10.1007/s 10806-013-9479-2

Verspecht, A., Vanhonacker, F., Verbeke, W., Zoons, J., \& Van Huylenbroeck, G. (2011). Economic impact of decreasing stocking densities in broiler 
production in Belgium. Poultry Science, 90(8), 1844-1851.

doi:https://doi.org/10.3382/ps.2010-01277

Vissers, L. S. M., De Jong, I. C., van Horne, P. L. M., \& Saatkamp, H. W. (2019).

Global prospects of the cost-efficiency of broiler welfare in middle-

segment production systems. Animals (Basel), 9(7).

doi:https://doi.org/10.3390/ani9070473

Vissers, L. S. M., Jongeneel, R. A., Saatkamp, H. W., \& Oude Lansink, A. G. J. M. (2021a). A multiple-standards framework to address externalities resulting from meat production. Applied Economic Perspectives and Policy, 1-14. doi:https://doi.org/10.1002/aepp.13152

Vissers, L. S. M., Saatkamp, H. W., \& Oude Lansink, A. G. J. M. (2021b). Analysis of synergies and trade-offs between animal welfare, ammonia emission, particulate matter emission and antibiotic use in Dutch broiler production systems. Agricultural Systems, 189, 103070. doi:https://doi.org/10.1016/j.agsy.2021.103070

Wagner, S., Angenendt, E., Beletskaya, O., \& Zeddies, J. (2015). Costs and benefits of ammonia and particulate matter abatement in German agriculture including interactions with greenhouse gas emissions. Agricultural Systems, 141, 58-68. doi:https://doi.org/10.1016/j.agsy.2015.09.003

Waldenstedt, L. (2006). Nutritional factors of importance for optimal leg health in broilers: A review. Animal Feed Science and Technology, 126(3), 291-307. doi:https://doi.org/10.1016/j.anifeedsci.2005.08.008

Welfare Quality Protocol ${ }^{\circledR}$. (2009). Welfare Quality ${ }^{\circledR}$ assessment protocol for poultry (broilers, laying hens). Retrieved from https://edepot.wur.nl/233471

Winkel, A., Mosquera, J., Groot Koerkamp, P. W. G., Ogink, N. W. M., \& Aarnink, A. J. A. (2015). Emissions of particulate matter from animal houses in the Netherlands. Atmospheric Environment, 111, 202-212. doi:https://doi.org/10.1016/j.atmosenv.2015.03.047

Winter, M., Fry, C., \& Carruthers, S. P. (1998). European agricultural policy and farm animal welfare. Food Policy, 23(3), 305-323. doi:https://doi.org/10.1016/S0306-9192(98)00036-0

Wood, D. J., \& Van Heyst, B. J. (2016). A review of ammonia and particulate matter control strategies for poultry housing. Transactions of the ASABE, 59(1), 329-344. doi:https://doi.org/10.13031/trans.59.10836

Zuidhof, M. J., Schneider, B. L., Carney, V. L., Korver, D. R., \& Robinson, F. E. (2014). Growth, efficiency, and yield of commercial broilers from 1957, 1978, and 2005. Poultry Science, 93(12), 2970-2982. doi:https://doi.org/10.3382/ps.2014-04291 


\section{Chapter 5}

\section{Subsidy or more policy certainty: what makes broiler farmers more likely to invest in particulate matter abatement techniques?}

Luuk S.M. Vissers, Jaap Sok, Alfons G.J.M. Oude Lansink

Submitted to Journal of Environmental Policy \& Planning 


\title{
Chapter 5
}

\begin{abstract}
Broiler houses are an important source of particulate matter $\left(\mathrm{PM}_{10}\right)$ emissions in the Netherlands. High concentrations of $\mathrm{PM}_{10}$ can threaten the environment and pose health risks to humans and animals. To address these problems, the Dutch government aims to reduce $\mathrm{PM}_{10}$ emissions originating from broiler houses by $50 \%$ in the period 2020-2030. This paper aimed to measure broiler farmers' preferences for investments in different $\mathrm{PM}_{10}$ abatement techniques and to explore the relations with socio-economic demographics and perceived obstacles for business development. A discrete choice experiment was conducted for this purpose. Results indicate that farmers were reluctant to invest in $\mathrm{PM}_{10}$ abatement techniques. When investing in these techniques, they had a general preference for techniques with a medium to high $\mathrm{PM}_{10}$ reduction efficiency $(31 \%-52 \%)$, rather than a very high $\mathrm{PM}_{10}$ reduction efficiency $(80 \%)$. Social factors and perceived obstacles for business development explained heterogeneity in farmers' preferences for $\mathrm{PM}_{10}$ abatement techniques and their willingness to invest. When investing in these techniques, farmers attached a higher relative importance to an exemption from future $\mathrm{PM}_{10}$ legislation than a subsidy. The findings imply that more policy-related certainty should be provided in addition to a financial compensation to incentivize farmers to invest in $\mathrm{PM}_{10}$ abatement techniques.
\end{abstract}

Keywords: particulate matter; broiler production; abatement techniques; discrete choice experiment; obstacles for business development; policy uncertainty 


\subsection{Introduction}

Broiler houses are a main source of particulate matter ${ }^{1}\left(\mathrm{PM}_{10}\right)$ emissions, contributing to around $10 \%$ of total $\mathrm{PM}_{10}$ emissions originating from agriculture in the EU (European Environment Agency, 2020b). A high concentration of $\mathrm{PM}_{10}$ in a particular broiler house not only compromises the respiratory health of the farmer and the broilers reared (Homidan et al., 2003), it also does so to people living in the vicinity. On top of that, these high concentrations can cause vegetation stress and ecosystem alteration (Grantz et al., 2003; Lammel et al., 2004; Seedorf, 2004; Cambra-López et al., 2010). To protect natural ecosystems and the health of its citizens, the EU has set limit values for air pollutants such as $\mathrm{PM}_{10}$ emissions (European Council Directive, 2008a). However, poor air quality remains a problem in the EU due to the widespread exceedance of these limit values (European Environment Agency, 2020a). In 2018, 15\% of the EU urban citizens were exposed to $\mathrm{PM}_{10}$ concentrations above the EU limit value, and $48 \%$ of the EU urban citizens were exposed to $\mathrm{PM}_{10}$ concentrations above the $\mathrm{WHO}$ air quality guidelines (European Environment Agency, 2021). This is mainly due to exceeded emission levels from the transport and construction sectors, but also from agriculture and industry (European Environment Agency, 2021).

To comply with the EU limit values, the Dutch government aims to reduce $\mathrm{PM}_{10}$ emissions originating from poultry houses by 50\% in the period 2020-2030 (Dutch Ministry of Infrastructure and Water Management, 2019). A potential pathway towards achieving this goal is the implementation of $\mathrm{PM}_{10}$ abatement techniques in poultry houses. In 2015, the low-emission livestock housing decree came into force, which sets a maximum emission level ${ }^{2}$ for $\mathrm{PM}_{10}$ from poultry housing in the Netherlands (Dutch Ministry of Infrastructure and Water Management, 2017). These maximum emission levels apply only to new poultry housing.

Nowadays, various techniques are available for reducing $\mathrm{PM}_{10}$ emissions, though they differ in reduction efficiency, purchase costs and operational costs (CambraLópez et al., 2010). $\mathrm{PM}_{10}$ abatement techniques are available that lower $\mathrm{PM}_{10}$ emissions from broiler houses up to 80\% (Expertise Centre Infomil, 2019b).

\footnotetext{
${ }^{1}$ Particulate matter are solid particles and liquid droplets found in the air. In broiler houses, feed, feces, feathers, and skin are the main source of particulate matter (Cambra-López et al., 2010). $\mathrm{PM}_{10}$ are inhalable particles with diameters that are generally 10 micrometres and smaller (United States Environmental Protection Agency, 2020).

${ }^{2}$ The maximum emission level for broiler housing is set at 16 gram $\mathrm{PM}_{10} /$ animal place/year (Dutch Ministry of Infrastructure and Water Management, 2017).
} 


\section{Chapter 5}

Vissers et al. (2021b) identified $\mathrm{PM}_{10}$ abatement techniques that are relatively costefficient, i.e. mitigate $\mathrm{PM}_{10}$ emissions at a relatively small increase in production costs. These findings point out that such abatement techniques have the potential to substantially reduce $\mathrm{PM}_{10}$ emissions from broiler houses while their financial consequences may be limited.

The extent to which abatement techniques can contribute to lowering $\mathrm{PM}_{10}$ emissions will ultimately also depend on the farmers' willingness to adopt. In recent years, the Dutch government launched subsidy schemes to stimulate investments in $\mathrm{PM}_{10}$ abatement techniques in poultry houses (Netherlands Enterprise Agency, 2020b). The most recent subsidy scheme of 2021 has a budget of 7 million euros that farmers can apply for. The question is whether farmers are willing to invest in these techniques and whether subsidies motivate them to do so?

Researchers frequently employ discrete choice experiments (DCE) to address similar questions (Van de Gucht et al., 2017; Zemo \& Termansen, 2018; Joshi et al., 2019; Blasch et al., 2020). In a DCE, the investment or technology to be adopted is represented by a combination of several attributes (Mangham et al., 2008). Using an experimental design, each respondent is shown a selection of the possible choice cards, on which two or more investment options are presented which vary in terms of attributes. An opt-out alternative represents the option to not invest or adopt. The attributes describe e.g. technical or financial aspects of the investment or technology but also may capture contextual aspects of the decision problem, such as the degree of personal advice or the degree of subsidy. DCE surveys usually also contain questions to measure (objective) socio-demographic variables which can be related to farmer's choice preference.

Earlier studies employed a DCE to elicit farmers' preferences for various technologies, such as automatic lameness-detection systems, precision farming technologies and biogas facilities (Van de Gucht et al., 2017; Zemo \& Termansen, 2018; Blasch et al., 2020). In these studies, socio-demographic, social and management variables were included in the DCE to explain preference heterogeneity. Joshi et al. (2019) included market and institutional variables in the DCE to explore heterogeneity in farmers' willingness to invest in labor saving technologies in India. Existing DCE studies however, did not address several aspects that are relevant in the context of farmers' investment decision. First, they only considered technologies that yield economic benefits (e.g. lower input costs), such as precision farming technologies. Hence, they did not consider farmers' 
willingness to invest in techniques that address environmental concerns but do not yield economic benefits, such as $\mathrm{PM}_{10}$ abatement techniques. Although it would be costly for farmers to invest in these techniques, they may still be willing to do so to address the environmental concerns and ensure their license to produce in the long run (Raedts et al., 2017). Second, existing DCE studies did not include obstacles that farmers believe prevent them from developing their business in their preferred way. Insight in these factors would be useful for agricultural policy and advisory services to help individual farms to address the environmental concerns related to broiler production. Third, existing DCE studies ignored the role of policy uncertainty in the willingness of farmers to adopt new techniques. Several studies indicated that policy uncertainty is an important driver of farmers' investment decisions (Isik, 2004; Lagerkvist, 2005). Insight in the effect of policy uncertainty on farmers' willingness to invest in new techniques is particularly relevant in countries where environmental problems are more prominent, such as the Netherlands (TNO, 2019). To the best of our knowledge, the impact of uncertainty about regulatory outcomes on farmers' willingness to invest in new techniques has not been addressed by the existing DCE literature.

In the light of the foregoing, this study aimed to measure farmers' preferences for investments in different $\mathrm{PM}_{10}$ abatement techniques and to explore the relation with socio-economic demographics and perceived obstacles for business development. The empirical study focuses on investments in $\mathrm{PM}_{10}$ abatement techniques by Dutch broiler farmers. The insights obtained from this paper can aid policy makers in the design of policies that aim at enhancing $\mathrm{PM}_{10}$ abatement techniques.

The remainder of this paper is structured as follows. Section 5.2 describes the design of the DCE and the collection and analysis of the data. The results are presented in Section 5.3. Section 5.4 contains the discussion. The policy implications and conclusions drawn from the study are provided in Section 5.5.

\subsection{Materials and methods}

\subsubsection{Overview of discrete choice experiment}

This study conducted a DCE to measure farmers' preferences for investments in different $\mathrm{PM}_{10}$ abatement techniques. The DCE was implemented in five steps, i.e. (1) selection of attributes of the investment options and their associated levels, (2) experimental (choice card) design (3) questionnaire design, (4) data collection and (5) empirical analysis of the DCE data. These steps are discussed in detail in the remainder of this section. 


\section{Chapter 5}

\subsubsection{Selection of attributes and levels}

The selection of attributes and levels of the investment in $\mathrm{PM}_{10}$ abatement techniques was based on literature. These attributes should characterize different types of $\mathrm{PM}_{10}$ abatement techniques and should include policy-related attributes that are relevant to the investment decision of farmers. The following attributes and levels were selected (see Table 5.1 for overview):

1. The $\mathbf{P M}_{10}$ abatement technique and the corresponding reduction efficiency. Expertise Centre Infomil (2019b) provides a list of $\mathrm{PM}_{10}$ abatement techniques, including the $\mathrm{PM}_{10}$ reduction efficiency, that are validated by the Dutch government. The techniques 'ionization carbon brushes' and 'ionization coronawires' were included as farmers are eligible for the subsidy under the current subsidy scheme when investing in them (Netherlands Enterprise Agency, 2020b). The technique 'conditioned air unit' was included as it is the only validated technique that yields a $\mathrm{PM}_{10}$ reduction efficiency higher than 60\% (Expertise Centre Infomil, 2019b).

2. The operating costs per broiler house ${ }^{3}$. The operating costs includes the maintenance costs and energy costs of the $\mathrm{PM}_{10}$ abatement technique. The levels were based on the operating costs of selected the $\mathrm{PM}_{10}$ abatement techniques and were obtained from Blanken et al. (2020).

3. The investment amount per broiler house ${ }^{3}$. The investment amount refers to the price and installation costs of the $\mathrm{PM}_{10}$ abatement technique. The investment amount was based on the market prices of the techniques and obtained from Blanken et al. (2020). As there were large differences in the investment amount of the selected techniques (ranging from $€ 15,750$ until $€ 191,250$ ), using these values as levels would result in unrealistic combinations between the technique and the investment amount. Therefore, conditional pricing was used to improve the realism of the investment options. In conditional pricing, the prices are shown for a specific combination of two attributes (Sawtooth Software, 2021a). The attribute investment amount per broiler house was set conditional on the attribute technique. A range of prices was defined for each technique, i.e. the 'default investment amount' (as obtained from literature), a ' $10 \%$ increase in the default investment amount', and a ' $10 \%$ decrease in the default investment amount'. A 10\% increase and decrease in the default

\footnotetext{
${ }^{3}$ The operating costs and investment amount were calculated for a broiler house with a floor surface of $2,100 \mathrm{~m}^{2}$.
} 


\section{Preferences for investments in $\mathrm{PM}_{10}$ abatement techniques}

investment amount was used because the market prices of $\mathrm{PM}_{10}$ abatement techniques were relatively stable and increased by a maximum of $10 \%$ in the past 5 years (Blanken et al., 2017).

4. The subsidy was expressed as the share of the total investment amount reimbursed by the government. The levels ' $40 \%$ ', and ' $60 \%$ ' were based on the current subsidy scheme of the Dutch government (Netherlands Enterprise Agency, 2020b). In this scheme, 40-60\% of the investment amount of $\mathrm{PM}_{10}$ abatement techniques is reimbursed, up to a limit of $€ 200,000$ per farm. This reimbursement applies only to indoor $\mathrm{PM}_{10}$ abatement techniques.

5. The exemption from future legislation describes the number of years farmers are exempted from future legislation if they invest in a $\mathrm{PM}_{10}$ abatement technique. Lagerkvist (2005) and Isik (2004) found that policy uncertainty strongly affects investment decisions. This attribute was included in the DCE to account for policy uncertainty. The levels ' 10 years' and '15 years' were based on the economic lifespan of the selected $\mathrm{PM}_{10}$ abatement techniques (Blanken et al., 2020).

Table 5.1 Overview of choice attributes and levels per choice attribute

\begin{tabular}{ll}
\hline Choice attribute & Levels \\
\hline Technique $\left(\mathrm{PM}_{10}\right.$ reduction & Ionization carbon brushes $(31 \%)$ \\
efficiency) & Ionization coronawires $(52 \%)$ \\
& Conditioned air unit $(80 \%)$ \\
Operating costs per broiler house & $€ 360 /$ year \\
& $€ 1170 /$ year \\
& $€ 2250 /$ year \\
Investment amount per broiler house & $10 \%$ decrease in investment amount \\
& $(€ 14,175 ; € 20,250 ; € 172,125)$ \\
& Default investment amount \\
& $(€ 15,750 ; € 22,500 ; € 191,250)$ \\
& $10 \%$ increase in investment amount \\
& $(€ 17,325 ; € 24,750 ; € 210,375)$ \\
Subsidy & $0 \%$ \\
& $40 \%$ \\
Exemption from future legislation & $60 \%$ \\
& 0 years \\
& 10 years \\
& 15 years
\end{tabular}

Note: the base levels are in cursive text. 


\section{Chapter 5}

\subsubsection{Experimental design}

The choice cards consisted of combinations of attributes and levels. The five attributes and three levels per attribute imply a full factorial design of $243\left(3^{\wedge} 5\right)$ combinations. As the sample size of our study was relatively small (500 broiler farmers, see section 5.2.4), the design was not blocked into different versions. The Sawtooth Software (2021b) environment was used to design the experiment. Sawtooth software's experimental design module created 100 unique versions of the questionnaire according to the following three principles: 1) no duplicate options are permitted within the same choice card 2) each attribute level appears as close to an equal number of times as possible in the experimental design 3) the attribute levels were chosen independently of each other. Each respondent was offered 10 choice cards, which is seen as an acceptable cognitive load (Bech et al., 2011). Each choice card consisted of two different investment options and a no investment option, i.e. an opt-out option (see Figure 5.1). The inclusion of an optout option in a DCE is known to improve realism in choices (Campbell \& Erdem, 2019). In the no investment option, farmers should assume that they continued with the current situation at their farm (status quo). The options were unlabeled.

\subsubsection{Questionnaire design}

The choice experiment questionnaire consisted of five parts: 1) questions about the farmers and their farm 2) explanation of the DCE 3 ) the choice cards of the DCE 4) questions about the plans the farmers are considering 5) farmers' perceived obstacles for business development. Hansson and Sok (2021) generated a list of obstacles that may impede the farmers' possibility to develop their business the way they would like to. These authors distinguished obstacles in various areas, such as financial resources, farm layout, competitors and prospective profitability in farm operations. Based on their list, 15 obstacles were selected that the authors considered as the most relevant ones in this study. Farmers were asked to indicate the extent to which they perceived each suggested obstacle to impede their possibilities to develop their business the way they would like to. The statements were measured on a 9-point Likert scale where 1 indicates 'not at all an obstacle' and 9 'very much an obstacle'. 
If you could choose between these three options, which option do you prefer?

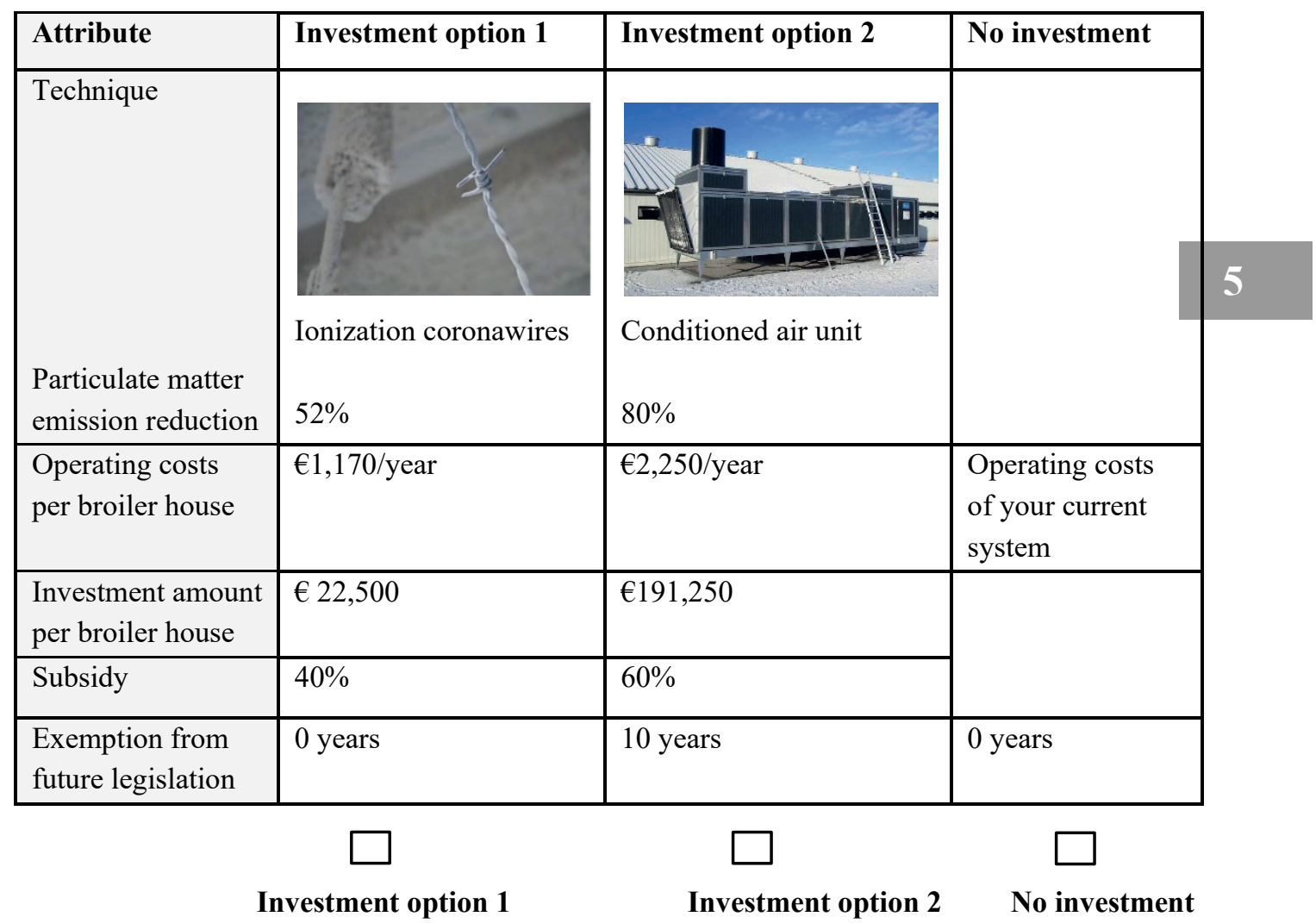

Figure 5.1 Example of a choice card (translated from Dutch)

\subsubsection{Data collection}

Before distributing the questionnaire among the farmers, it was announced and promoted via agricultural news websites. The sample consisted of 500 broilers farmers that reared more than 10,000 broilers. The questionnaire was held in May 2021 and was distributed via email. The farmers were informed that they could win a gift coupon of 20 euros and that they could receive the results of the study upon request. After one week, a reminder was sent to the respondents. In total 86 farmers responded, which is a response rate of 17 percent. In total, 50 gift coupons were randomly assigned to the respondents. Observations with missing values were excluded from the analysis, resulting in a sample size of 63 respondents. This small sample size is a rather common limitation of DCE studies targeting farmers, 


\section{Chapter 5}

because this population is asked frequently to participate in questionnaires ${ }^{4}$, leading to an increasing reluctance to participate.

The stated choices differed considerably among the respondents, as nearly $30 \%$ of the respondents always chose the 'no investment' option whereas $28 \%$ always chose one of the investment options. The descriptive statistics of the respondents are provided in Appendix 5A. Most farmers were 50 years or older and reared more than 90.000 broilers. More than $50 \%$ of the respondents had an income from non-farm activities. The sample representativeness was checked by comparing the values of the socio-economic characteristics with values obtained from other sources. In 2019, the average broiler farm had 79,000 broilers and the average solvency rate of the farm was 0.61 (Wageningen Economic Research, 2021). In the Netherlands, around $60-70 \%$ of the total number of broilers are reared in conventional systems, whereas the remaining $30-40 \%$ are reared in more animal welfare friendly production systems (Stadig, 2019). Hence, the sample is representative in terms of animal welfare production systems and the solvency rate. However, large farms are overrepresented in this study.

Table 5.2 provides a description of the variables included in the DCE. The nominal variables were converted into a dummy variable before entering the choice model. For instance, the variable animal welfare system was converted into a dummy variable, where 0 indicated the conventional system and 1 indicated a more animal welfare friendly system. In case of the dummy variable successor, it was assumed that farmers that selected 'unsure' or 'I don't want to say' did not have a successor. Table 5.2 shows that farmers perceived external factors (e.g. rules and regulation) as more constraining than internal factors (e.g. knowledge and competences within the farm). Farmers perceived rules and regulation, foreign competition and profitability of future investments as the most constraining obstacles for business development. The obstacles knowledge and competences within the farm, support from business partners and support from my family were perceived as the least constraining obstacles.

\footnotetext{
${ }^{4}$ Many other studies that targeted farmers also had small sample sizes in their DCE, such as Chèze et al. (2020) (90 respondents) and Hudson and Lusk (2004) (49 respondents). Based on the rule of thumb proposed by Orme (1998) and Johnson and Orme (2003), 50 respondents were required for this study to calculate the main effects of the attributes.
} 


\section{Preferences for investments in $\mathrm{PM}_{10}$ abatement techniques}

Table 5.2 Description of the socio-economic variables and perceived obstacles

\begin{tabular}{|c|c|c|c|}
\hline Variable name & Description & Mean & S.D. \\
\hline \multicolumn{4}{|l|}{ Socio-economic variables } \\
\hline Age & Age of the farmer in number of years & 52.16 & 10.7 \\
\hline Higher education & $\begin{array}{l}\text { Dummy variable, } 1 \text { if farmer has a } \\
\text { higher education, } 0 \text { otherwise }\end{array}$ & 0.28 & 0.45 \\
\hline Income non-agricultural & $\begin{array}{l}\text { Dummy variable, } 1 \text { if farmer has } \\
\text { income from non-agricultural } \\
\text { activities, } 0 \text { otherwise }\end{array}$ & 0.56 & 0.50 \\
\hline Successor & $\begin{array}{l}\text { Dummy variable, } 1 \text { if farmer has a } \\
\text { successor or is younger than } 50 \text { years, } \\
0 \text { otherwise }\end{array}$ & 0.22 & 0.41 \\
\hline Farm size & $\begin{array}{l}\text { Dummy variable, } 1 \text { if farmer has } \\
60,000 \text { broilers or more, } 0 \text { otherwise }\end{array}$ & 0.58 & 0.49 \\
\hline Animal welfare system & $\begin{array}{l}\text { Dummy variable, } 1 \text { if farmer has a } \\
\text { more animal welfare friendly system, } \\
0 \text { if conventional }\end{array}$ & 0.55 & 0.49 \\
\hline Current $\mathrm{PM}_{10}$ abatement technique & $\begin{array}{l}\text { Dummy variable, } 1 \text { if farmer applies a } \\
\mathrm{PM}_{10} \text { abatement technique }\end{array}$ & 0.66 & 0.48 \\
\hline Solvency rate & $\begin{array}{l}\text { Dummy variable, } 1 \text { if solvency rate of } \\
\text { the farm is } 40 \% \text { or higher, } 0 \text { otherwise }\end{array}$ & 0.27 & 0.44 \\
\hline Plan expansion & $\begin{array}{l}\text { Likelihood that farmer will expand } \\
\text { production capacity in the next } 5 \\
\text { years, measured on a } 5 \text {-point Likert } \\
\text { scale. The variable was mean centered } \\
\text { before entering the model. }\end{array}$ & 2.19 & 1.12 \\
\hline Plan system & $\begin{array}{l}\text { Likelihood that farmer will shift to a } \\
\text { different animal welfare system in the } \\
\text { next } 5 \text { years, measured on a } 5 \text {-point } \\
\text { Likert scale. The variable was mean } \\
\text { centered before entering the model. }\end{array}$ & 2.48 & 1.23 \\
\hline \multicolumn{4}{|c|}{ Perceived obstacles for business development } \\
\hline Rules and regulation & Each perceived obstacle was measured & 7.60 & 2.01 \\
\hline Foreign competition & on a 9-point Likert scale, where 1 & 5.89 & 2.58 \\
\hline Profitability of future investments & indicates 'not at all an obstacle' and 9 & 5.68 & 2.30 \\
\hline Availability of own financial resources & 'very much an obstacle'. The obstacles & 5.10 & 2.34 \\
\hline Getting bank loans approved & were mean centered before entering & 4.86 & 2.47 \\
\hline Profitability of current activities & the model. & 4.95 & 2.20 \\
\hline Ability to fulfill payment obligations & & 4.30 & 2.20 \\
\hline Availability of farm successor & & 4.00 & 2.69 \\
\hline Location of the farm & & 3.63 & 2.51 \\
\hline Availability of production factors & & 3.70 & 2.26 \\
\hline Consumer demand for my products & & 3.33 & 2.17 \\
\hline Expertise of advisory services & & 3.28 & 2.13 \\
\hline Support from my family & & 3.21 & 2.50 \\
\hline Support from business partners & & 3.12 & 2.14 \\
\hline $\begin{array}{l}\text { Knowledge and competences within the } \\
\text { farm }\end{array}$ & & 2.19 & 1.52 \\
\hline
\end{tabular}




\section{Chapter 5}

\subsubsection{Empirical analysis of DCE data}

A conditional logit model specification was used for analyzing the DCE data. The use of a conditional logit model is justified only if the data satisfy the independence of irrelevant alternatives (IIA) assumption (Mazzanti, 2003). To test for IIA, a Hausman test was performed that compared the coefficient estimates before and after removing of one of the alternatives. The null hypothesis could not be rejected (at 5\% significance level) indicating that there was no evidence that the IIA assumption has been violated. Therefore, the use of the conditional logit model was justified for the analysis of the data.

The conditional logit models were based on the random utility framework of McFadden (1974) and Lancaster's theory consumer of choice (Lancaster, 1966). The utility derived from the investment option is the sum of the utility derived from the attributes (Lancaster, 1966). Based on the random utility framework of McFadden (1974), the utility function can be decomposed into a deterministic component $\left(V_{i j}\right)$ and a stochastic component $\left(\varepsilon_{i j}\right)$ :

$$
U_{i j}=V_{i j}+\varepsilon_{i j}
$$

Where $U_{i j}$ is the utility derived from by decision maker $i$ from alternative $j$. The random error term $\varepsilon_{i j}$ captures unobserved heterogeneity across individuals. The error term was assumed to be independently and identically distributed extreme value.

Four conditional logit models were estimated and compared in terms of goodnessof fit. First, a basic conditional logit model was run, including attributes and an alternative-specific constant (ASC) only. The ASC reflects the relative utility farmers attach to the 'no investment' option compared to the investment option with base levels. The ASC was coded as a dummy variable in the model, where the value 1 indicates a preference for the 'no investment' option. The basic conditional logit model takes the form:

$$
V_{i j}=\beta_{s} * X_{s j}
$$

Where $\beta_{s}$ is the parameter to be estimated. $X_{s j}$ reflects the choice attributes of investment option $j$ with levels $s$. Second, a parsimonious model was estimated that included interaction terms between the attributes, the ASC and the socioeconomic variables: 


$$
V_{i j}=\beta_{s} * X_{s j}+\left(\sum_{p} \alpha_{s p} * z_{p i}\right) * X_{s j}
$$

Where $z_{p i}$ represents the socio-economic characteristics and subscript $p$ reflects the number of socio-economic characteristics. $\alpha_{s p}$ is the parameter to be estimated. Third, another parsimonious model was run that included interaction terms between the attributes, the ASC and the perceived obstacles.

$$
V_{i j}=\beta_{s} * X_{s j}+\left(\sum_{l} \tau_{s l} * y_{l i}\right) * X_{s j}
$$

Where $y_{l i}$ are the perceived obstacles of decision maker $i$, and subscript $l$ reflects the number of perceived obstacles. The parameter $\tau_{s l}$ is estimated by the model. Fourth, a rich specification of the model was estimated including interaction terms of the socio-economic variables and the perceived obstacles:

$$
V_{i j}=\beta_{s} * X_{s j}+\left(\sum_{p} \alpha_{s p} * z_{p i}+\sum_{l} \tau_{s l} * y_{l i}\right) * X_{s j}
$$

For each model, backward elimination ${ }^{5}$ was applied to eliminate statistically insignificant (at 10\%) interaction terms. The models were estimated using Stata 16 (StataCorp, 2019).

\subsection{Results}

\subsubsection{Fit of the models}

The likelihood ratio test was used to compare the fit of the four estimated models ${ }^{6}$. The likelihood ratio test indicated that the rich model fits the data better ( $\mathrm{p}$-value $<0.001)$ than the two parsimonious models. The McFadden's pseudo $\mathrm{R}^{2}$ of the basic model (0.06) was below the range for a good model fit (0.20-0.40) (McFadden, 1979). The McFadden's pseudo $\mathrm{R}^{2}$ increased considerably (from 0.06 to 0.23 ) when including either the interaction terms of the socio-economic variables or the perceived obstacles. The rich model fitted the data well as the McFadden's pseudo $\mathrm{R}^{2}(0.40)$ was in the range for a good model fit $(0.20-0.40)$.

\footnotetext{
${ }^{5}$ In backward elimination, all the interaction variables are entered into the equation first. Consequently, the insignificant variables (p-value larger than 10\%) are removed one-byone from the model (Dunkler et al., 2014).

${ }^{6} \mathrm{Six}$ respondents did not fill in the perceived obstacles in the questionnaire. To execute the likelihood ratio test, these observations had to be removed in all models. After removing these observations, the interaction term 'higher education $\mathrm{x}$ no investment' became significant (at 1\%). Removing these observations did not affect the significance level and sign of all other coefficients.
} 


\section{Chapter 5}

The AIC and BIC values of the rich model were lowest, followed by the two parsimonious models and the basic model. This finding indicates that the rich model fits the data best.

\subsubsection{Main effects}

Table 5.4 shows the regression results of the basic model and the rich model (see page 126). The regression results of the parsimonious models are provided in Appendix 5B. In the models, a positive coefficient implies an increase in the utility relative to investment option with base levels, making the investments in $\mathrm{PM}_{10}$ reducing techniques more likely (and vice versa). Nearly all coefficients had plausible signs, as expected on the basis of microeconomic theory. For instance, the coefficient of $40 \%$ subsidy was positive, implying that the likelihood of investing in a $\mathrm{PM}_{10}$ abatement technique increased when a subsidy was provided, compared to the base level of $0 \%$ subsidy. The levels for the attribute investment amount were statistically insignificant at $10 \%$, while the levels for the attribute operating costs were statistically insignificant at 5\% (basic model) or 10\% (rich model). This finding indicates that changes in the investment amount and operating costs did not affect farmers' preferences for $\mathrm{PM}_{10}$ abatement techniques. With regards to the statistically significant coefficients (at 10\%), farmers had a negative general preference towards the conditioned air unit ( $80 \% \mathrm{PM}_{10}$ reduction) relative to the base level of ionization carbon brushes (31\% PM 10 reduction). The likelihood of investing in a $\mathrm{PM}_{10}$ abatement technique increased when 10 or 15 years exemption from future legislation was provided, compared to the base level of 0 years exemption from future legislation. The coefficient of no investment shows the relative utility farmers attached to the no investment option compared to the investment option with base levels. The coefficient of no investment was positive and significant (at 1\%), indicating that if farmers chose the no investment option, their utility increased. Hence, on average, farmers place a positive value on maintaining the status quo.

A probability analysis was conducted to measure the relative importance of each level (Lancsar et al., 2007). Table 5.3 provides the results of the analysis. The baseline shows the predicted probabilities of the base case where all levels have been set to zero. Subsequent rows show how these predicted probabilities would change in response to a change in the levels of investment option 1 . The last column shows the relative importance of the levels with respect to its impact on the probability of choosing a particular alternative. The table shows that the conditioned air unit had the highest relative importance, while ionization 


\section{Preferences for investments in $\mathrm{PM}_{10}$ abatement techniques}

coronawires had the lowest relative importance. Furthermore, the table shows that exemption from future legislation (10 years or 15 years) had a higher relative importance than a subsidy $(40 \%$ or $60 \%)$.

Table 5.3 Probability analysis

\begin{tabular}{|c|c|c|c|c|c|c|c|}
\hline \multirow[t]{2}{*}{ Attribute } & \multicolumn{3}{|c|}{ Probability of choice } & \multicolumn{3}{|c|}{ \% change in probability } & \multirow[t]{2}{*}{ Order } \\
\hline & $\begin{array}{l}\text { Investm. } \\
\text { option } 1\end{array}$ & $\begin{array}{l}\text { Investm. } \\
\text { option } 2\end{array}$ & $\begin{array}{l}\text { No } \\
\text { investm. }\end{array}$ & $\begin{array}{l}\text { Investm. } \\
\text { option } 1\end{array}$ & $\begin{array}{l}\text { Investm. } \\
\text { option } 2\end{array}$ & $\begin{array}{l}\text { No } \\
\text { investm. }\end{array}$ & \\
\hline $\begin{array}{l}\text { Baseline (ASC } \\
\text { only) }\end{array}$ & 0.26 & 0.26 & 0.47 & & & & \\
\hline \multicolumn{8}{|l|}{ Technique } \\
\hline $\begin{array}{l}\text { Ionization } \\
\text { coronawires }\end{array}$ & 0.27 & 0.26 & 0.47 & 2.80 & 0.11 & 1.61 & 10 \\
\hline $\begin{array}{l}\text { Conditioned } \\
\text { air unit }\end{array}$ & 0.16 & 0.30 & 0.54 & 40.30 & 13.63 & 14.76 & 1 \\
\hline \multicolumn{8}{|l|}{ Operating costs } \\
\hline$€ 1170 /$ year & 0.25 & 0.27 & 0.48 & 6.17 & 3.14 & 1.68 & 8 \\
\hline$€ 2250 /$ year & 0.22 & 0.28 & 0.50 & 17.32 & 6.64 & 5.91 & 4 \\
\hline \multicolumn{8}{|c|}{ Investment amount } \\
\hline $10 \%$ decrease & 0.27 & 0.26 & 0.46 & 4.63 & 0.43 & 2.32 & 9 \\
\hline $10 \%$ increase & 0.28 & 0.26 & 0.46 & 8.47 & 1.73 & 3.72 & 7 \\
\hline \multicolumn{8}{|l|}{ Subsidy } \\
\hline $40 \%$ & 0.30 & 0.25 & 0.44 & 15.29 & 4.01 & 6.24 & 6 \\
\hline $60 \%$ & 0.31 & 0.25 & 0.44 & 18.86 & 5.13 & 7.59 & 5 \\
\hline \multicolumn{8}{|c|}{ Exemption from future legislation } \\
\hline 10 years & 0.33 & 0.24 & 0.43 & 25.49 & 7.34 & 10.05 & 3 \\
\hline 15 years & 0.35 & 0.24 & 0.42 & 31.45 & 9.77 & 12.00 & 2 \\
\hline
\end{tabular}

\subsubsection{Interaction effects with socio-economic variables}

The socio-economic variables interacted only significantly (at $10 \%$ ) with no investment and technique in the rich model (see Table 5.4) and the parsimonious model with socio-economic variables (see Appendix 5B). The interactions with no investment show which type of farmers are more willing to invest in $\mathrm{PM}_{10}$ abatement techniques, and thus are more willing to move away from the status quo. The relationship between successor and no investment was negative and statistically significant (at 1\%) indicating that if farmers did not have a successor, they were less likely to invest in $\mathrm{PM}_{10}$ abatement techniques. The coefficient of the interaction terms between age and no investment, and between farm size and no investment were positive and significant (at 1\%). These results indicate that indicate that farmers operating at a large scale were less likely to invest in $\mathrm{PM}_{10}$ abatement techniques, as were older farmers. When investing in $\mathrm{PM}_{10}$ abatement techniques, farmers operating at a large scale had a stronger preference for the 


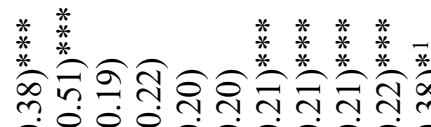

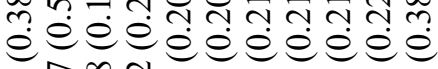

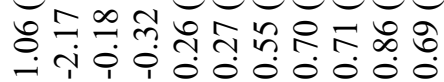

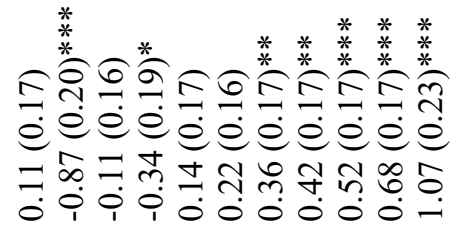
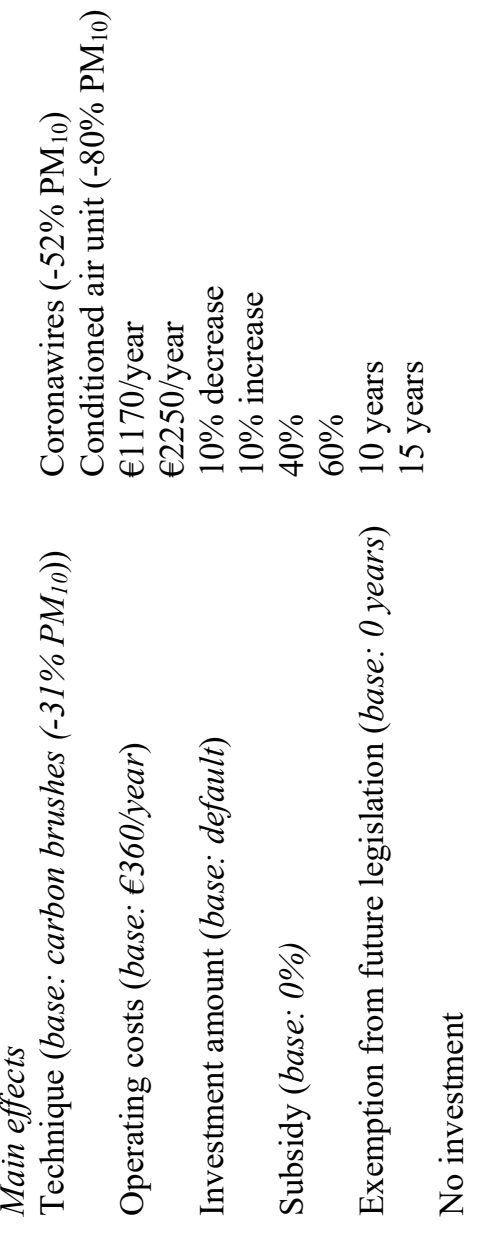

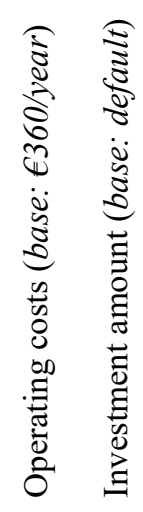
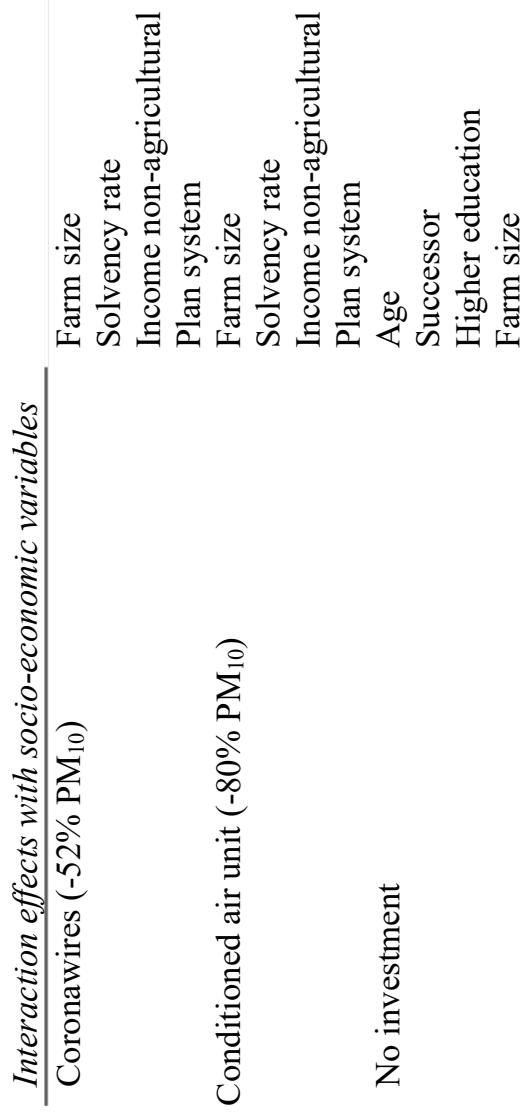

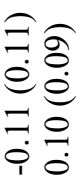

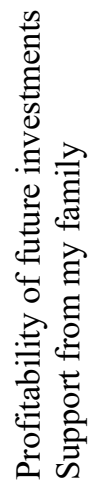

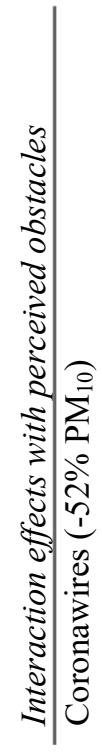




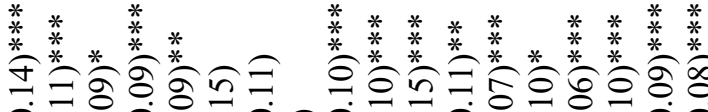

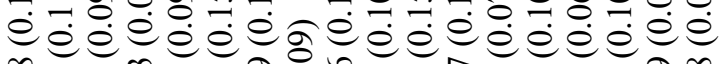
iono

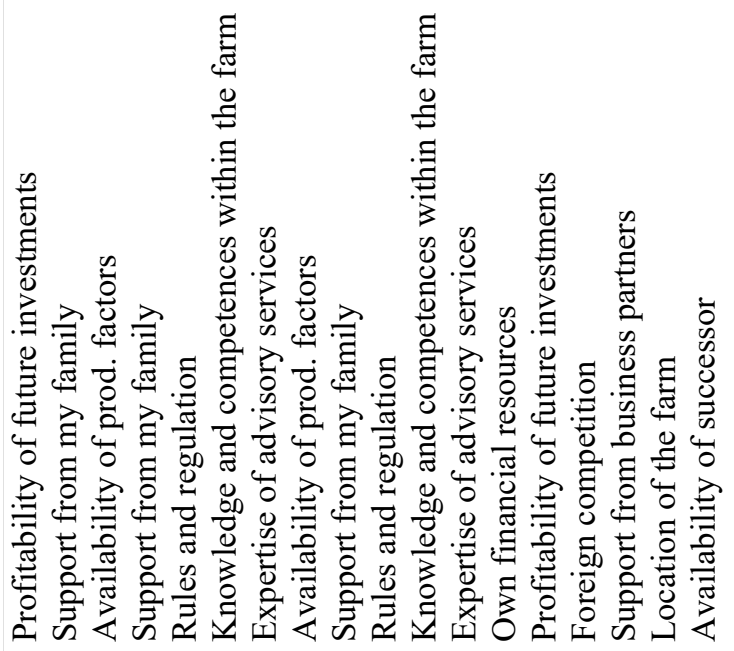

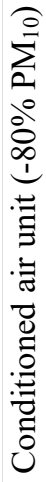

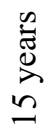

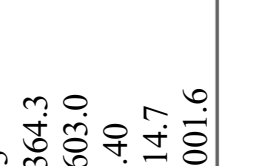

兽离

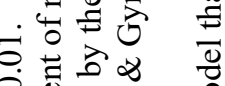

$\overrightarrow{0}, \overline{0}$

ᄂ.

○.

요

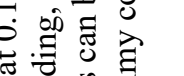

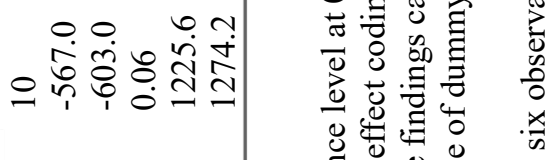

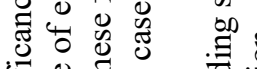

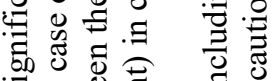

ज $\Xi$ 氙

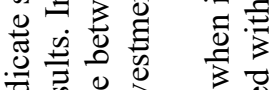

跑过

节

* Ð巳巳巳

웧ㅂ

ส

* 0 वं

मे তृ

:

들워

एँ

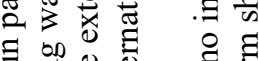

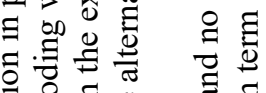

氜 $0 . \Xi 0$

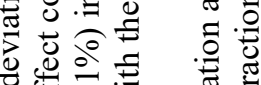

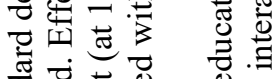

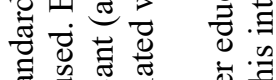

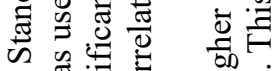

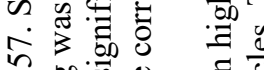

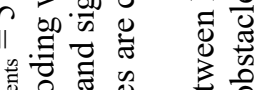

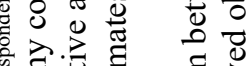

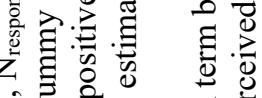

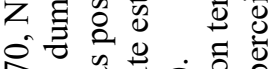

유휴.

॥

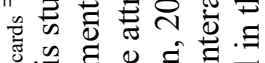

.

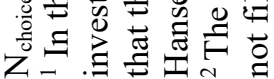




\section{Chapter 5}

conditioned air unit ( $80 \%$ PM 10 emission reduction) compared to farmers operating at a smaller scale. Farmers with an income from non-agricultural activities preferred the $\mathrm{PM}_{10}$ abatement technique with the lowest reduction efficiency, i.e. ionization carbon brushes (31\% PM10 emission reduction). The relationship between animal welfare system and no investment was statistically insignificant (at $10 \%$ ), indicating that the animal welfare system did not affect the likelihood that farmers invest in $\mathrm{PM}_{10}$ abatement techniques. Similarly, results did not indicate a significant relationship (at 10\%) between the solvency rate of the farm and the likelihood that farmers invest in $\mathrm{PM}_{10}$ abatement techniques.

\subsubsection{Interaction effects with perceived obstacles for business development} Only perceived obstacles that interacted with no investment, and the attributes technique and exemption from future legislation were statistically significant (at 10\%) in our models (see Table 5.4 and Appendix 5B). Most significant interaction terms (at 10\%) between the perceived obstacles and no investment were positive, indicating that farmers were less likely to invest in $\mathrm{PM}_{10}$ abatement techniques when they perceived an obstacle as constraining. For instance, farmers who perceived profitability of future investments as constraining were less likely to invest in $\mathrm{PM}_{10}$ abatement techniques. Furthermore, these farmers disliked the conditioned air unit ( $80 \%$ PM 10 emission reduction). Farmers who perceived the obstacle rules and regulation as constraining had a greater preference for 10 years or 15 years exemption from future legislation. Farmers who perceived the location of the farm as constraining (e.g. near residential area) were more willing to invest in a $\mathrm{PM}_{10}$ abatement technique. The obstacle support from my family had a significant negative relationship (at $1 \%$ ) with 10 years and 15 years exemption from future legislation. This finding indicates that farmers who perceived this obstacle as constraining, had a greater preference for 0 years exemption from future legislation.

\subsection{Discussion}

This paper aimed to measure farmers' preferences for investments in different $\mathrm{PM}_{10}$ abatement techniques and to explore the relations with socio-economic demographics and perceived obstacles for business development. The results indicated that on average, farmers placed a positive value on maintaining the status quo, i.e. they were reluctant to invest in $\mathrm{PM}_{10}$ abatement techniques. These results are in line with Blasch et al. (2020), who found that farmers are in general reluctant towards the adoption of precision farming technologies. The farmers' reluctance to invest in $\mathrm{PM}_{10}$ abatement techniques may be due to the increase of production costs 
due to the investment (Blanken et al., 2020), which are not compensated by an output price premium. Therefore, farmers have a financial disincentive to invest in these techniques. Earlier research of Gocsik et al. (2015) showed that broiler farmers' willingness to invest in more animal welfare friendly production systems crucially depends on financial feasibility. Furthermore, these same authors found that farmers are reluctant to convert to systems requiring irreversible changes, as this limits their flexibility to restore the previous farm situation. The farmers' reluctance to invest in $\mathrm{PM}_{10}$ abatement techniques can also be explained by the 'endowment effect'. This effect is well known and documented in the DCE literature and states that participants have a preference for retaining their current situation and thus a tendency to choose what they already have (Campbell $\&$ Erdem, 2019).

If farmers were to invest in a $\mathrm{PM}_{10}$ abatement technique, then ionization carbon brushes (31\% PM 10 emission reduction) and ionization coronawires (52\% $\mathrm{PM}_{10}$ emission reduction) would be the most likely options, whereas the interest for the conditioned air unit ( $80 \%$ PM10 emission reduction) appears small among the farmers. This finding can be explained by the fact that the investment amount of the conditioned air unit was relatively large (between $€ 172,125$ and $€ 210,375$ euro per broiler house). Blasch et al. (2020) and Long et al. (2016) found that the high initial investment outlay is one of the main barriers for the adoption of new technologies. Our results indicated that farmers were indifferent between default investment amount, 10\% decrease in investment amount and $10 \%$ increase in investment amount. A possible explanation for this finding might be that most farmers ignored the investment amount because of small differences in their levels.

The policy-related attributes subsidy and exemption from future legislation were among the most important drivers explaining choice behavior. The importance assigned to exemption from future legislation can be explained by our finding that farmers perceived rules and regulations as the most constraining factor for business development. Another possible explanation is that uncertainty about environmental policies has the potential to impact the investment decision of farmers (Isik, 2004). Earlier studies found a negative impact of uncertainty on investment decisions in agricultural technologies (Carey \& Zilberman, 2002; Isik, 2004). Exemption from future legislation can be a solution to alleviate policy uncertainty, and can therefore stimulate farmers to invest in $\mathrm{PM}_{10}$ abatement techniques. 


\section{Chapter 5}

The results of our study indicated that farmers who perceived support from my family as constraining, where more likely to select investment options that included 0 years exemption from future legislation. Furthermore, results from the parsimonious model with perceived obstacles showed that farmers who perceived support from business partners as constraining, were more likely to select investment options that included $0 \%$ subsidy. In the literature, these obstacles are also summarized as social capital (Hansson \& Sok, 2021). Our findings suggest that farmers with less social capital have a lower trust in the government. The relationship between social capital and trust in the government is well established in the literature (Brehm \& Rahn, 1997; Keele, 2007), and is in line with the findings of our study. The results showed that farmers who perceived support from business partners as constraining, were less likely to invest in $\mathrm{PM}_{10}$ abatement techniques. This finding is consistent with that of Blasch et al. (2020), who found that social networks amongst farmers are essential for the adoption of precision farming technologies.

Our study has several limitations, which should be taken into account when interpreting the results. Although our sample was representative in terms of animal welfare production systems and the solvency rate, it was rather small and overrepresented by large farms (more than 90,000 broilers). A small sample size is a common drawback in DCE studies targeting farmers (Chèze et al., 2020), especially when treating sensitive issues such as environmental measures. Based on our experimental design, the number of respondents (57) satisfied the minimum number of respondents (50) required for analyzing the main effects of the attributes (Orme, 1998; Johnson \& Orme, 2003). Another limitation of our study is that latent social-psychological constructs (e.g. attitude) were not incorporated in the choice model. These constructs may reflect part of the heterogeneity in preferences of the farmers for investments in $\mathrm{PM}_{10}$ abatement techniques. Future research could include social-psychological constructs in choice models to improve the understanding of farmers' willingness to invest in $\mathrm{PM}_{10}$ abatement techniques.

\subsection{Conclusion and policy implications}

This study aimed to measure farmers' preferences for investments in different $\mathrm{PM}_{10}$ abatement techniques and to explore the relations with socio-economic demographics and perceived obstacles for business development. We conclude that farmers are reluctant to invest in $\mathrm{PM}_{10}$ abatement techniques, i.e. prefer the status quo. Furthermore, we conclude that heterogeneity in these preferences can particularly be explained by social factors (e.g. age of the farmer) and perceived 
obstacles for business development (e.g. foreign competition). In general, farmers that perceived these obstacles as constraining were less willing to invest in $\mathrm{PM}_{10}$ abatement techniques.

Our study has two implications for the design of future policies that aim at enhancing the adoption of $\mathrm{PM}_{10}$ abatement techniques. The first policy implication derives from the results on policy uncertainty perceived by farmers. In the DCE, the attribute exemption from future legislation was included to account for policy uncertainty. Our study implies that policy uncertainty disincentivizes farmers to invest in $\mathrm{PM}_{10}$ abatement techniques. Results show that particularly farmers who perceived rules and regulation and knowledge and competences within the farm as obstacles for business development, were more willing to invest in a $\mathrm{PM}_{10}$ abatement technique when exemption from future legislation was provided. The second policy implication derives from the results on the role of subsidies in the farmers' attitude towards investments in $\mathrm{PM}_{10}$ emission reduction. Results indicate a preference among farmers for ionization techniques (31-52\% $\mathrm{PM}_{10}$ emission reduction). The interest in the technique conditioned air unit $\left(80 \% \mathrm{PM}_{10}\right.$ emission reduction) was relatively small. This finding suggests that subsidy schemes are more likely successful when focusing on techniques that have a medium to high $\mathrm{PM}_{10}$ reduction efficiency (31-52\%), rather than techniques with a very high $\mathrm{PM}_{10}$ reduction efficiency $(80 \%)$. The results also show a high heterogeneity in farmers' preferences for $\mathrm{PM}_{10}$ abatement techniques and in their willingness to invest in $\mathrm{PM}_{10}$ abatement techniques. This finding favors differentiated payments by farmer type and supports targeted subsidization of farmers that are willing to invest in $\mathrm{PM}_{10}$ abatement techniques.

\section{Acknowledgements}

This work was financially supported by the Food Pro-tec-ts project. This project is carried out within the framework of the INTERREG V A program "DeutschlandNederland" and is co-financed by the European Regional Development Fund (ERDF) and the Dutch Ministry of Economic Affairs and Climate Change, the Ministry of Economic Affairs, Innovation, Digitalization and Energy of North Rhine-Westphalia and the provinces of Gelderland, Limburg and North Brabant. It is accompanied by the program management at the Euregio Rhein-Waal. 


\section{Chapter 5}

\section{Appendix}

Appendix 5A. Descriptive statistics

Characteristic

Study respondents, n (\%)

Age

18-40 years

$11(17.2)$

41-50 years

$13(20.3)$

51-60 years

$28(43.8)$

$>60$ years

$12(18.8)$

Education level

High school diploma or less

$12(19.1)$

Second professional education

$33(52.4)$

Higher education

$18(28.6)$

Non-farm income

Yes

$36(57.1)$

No

27 (42.9)

Successor if farmer is $\mathbf{5 0}$ years or older

Yes

$14(34.1)$

No

$10(24.4)$

Unsure

$16(39.0)$

I don't want to say

Farm size ${ }^{2}$

0-30.000 broilers

$17(27.0)$

30.001-60.000 broilers

$9(14.3)$

60.001- 90.000 broilers

$11(17.5)$

90.001 or more broilers

$26(41.3)$

Animal welfare system ${ }^{1}$

Conventional

$23(36.5)$

New Dutch retail standard

$18(28.6)$

Extensive indoor+

$15(23.8)$

Organic

$4(6.3)$

Other

$4(6.3)$

Current $P_{10}$ abatement technique ${ }^{2}$

$32(50.7)$

Heat exchanger

$12(19.0)$

Other technique

$22(34.9)$

Solvency rate

I do not apply a $\mathrm{PM}_{10}$ abatement technique

$16(25.8)$

$0-0.40$

$16(25.8)$

$0.41-0.60$

$15(24.2)$

$2(3.2)$

$0.81-1.00$

$13(21.0)$

Likelihood that farmer will expand production capacity in the next 5 years

$19(30.6)$

Very unlikely

$23(37.1)$

Unlikely

$13(21.0)$

Neutral

$3(4.8)$

Likely

$4(6.5)$

Likelihood that farmer will shift to a different animal welfare system in the next 5 years 
Very unlikely

${ }^{1}$ Totals do not add up to $100 \%$ because farmers can apply a different system in each broiler house.

${ }^{2}$ Totals do not add up to $100 \%$ because farmers can apply a different $\mathrm{PM}_{10}$ abatement technique in each broiler house

Appendix 5B. Estimation results from parsimonious models (see next page for table)

Table footnotes:

${ }^{1}$ In this study, dummy coding was used. Effect coding was applied to validate the results. In case of effect coding, the coefficient of no investment was positive and significant (pvalue $<0.001)$ in the extended model. The difference between these findings can be explained by the fact that the attribute estimates are correlated with the alternative specific constant (no investment) in case of dummy coding (Bech \& Gyrd-Hansen, 2005).

${ }^{2}$ The interaction term between higher education and no investment was insignificant when including six observations in the model that did not fill in the perceived obstacles. This interaction term should therefore be interpreted with caution. 


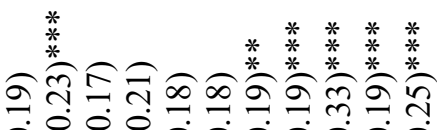

é $\dot{e} \vec{e} \dot{e} \vec{e} \dot{e} \dot{e}$

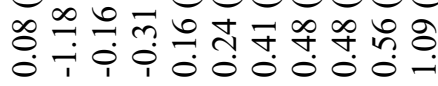

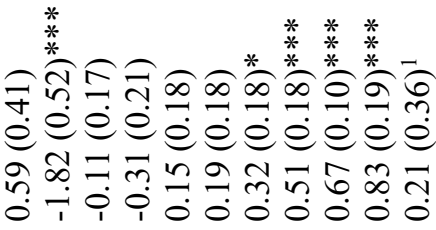

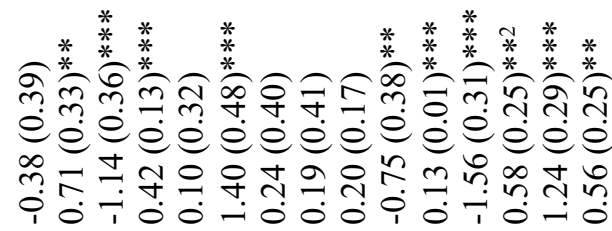

$\overbrace{2}^{9}$

ڤㅇํㅇ

穴.”

空言

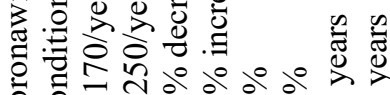

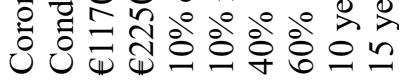

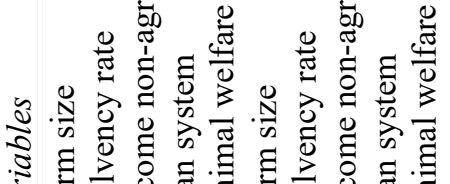

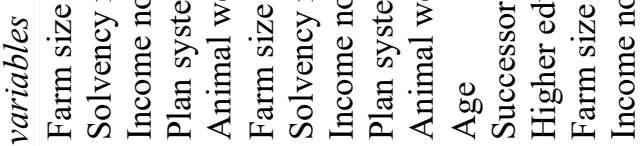

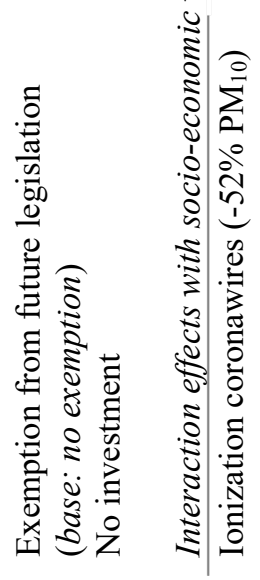

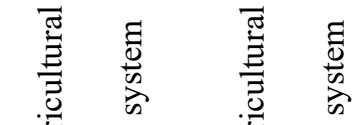

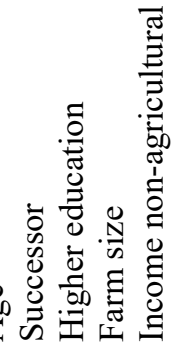

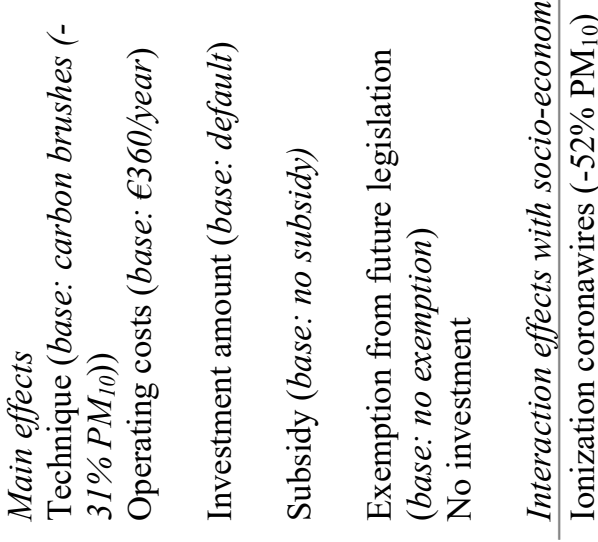

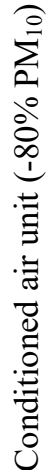

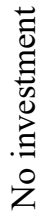




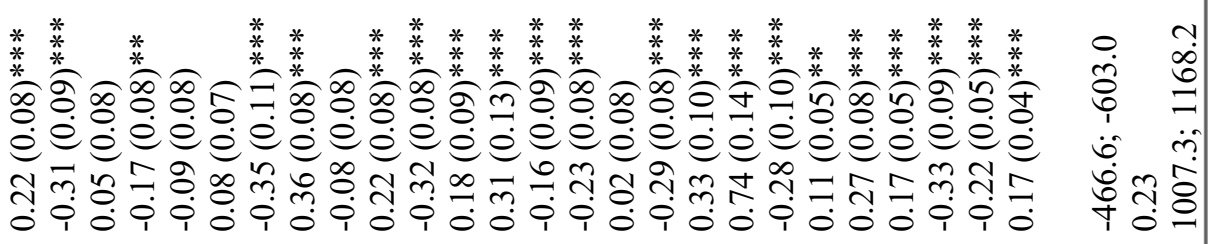
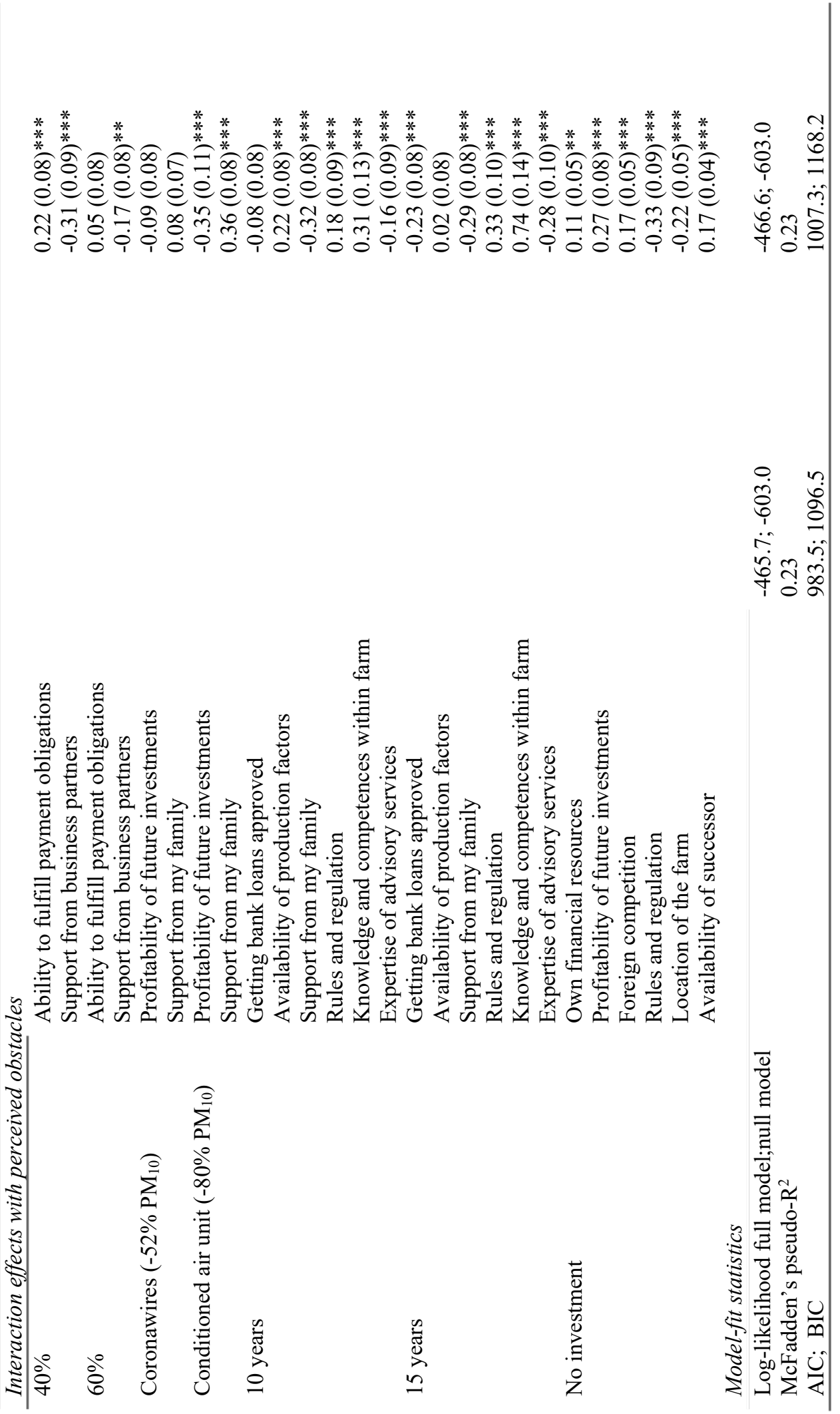
Chapter 5

\section{References}

Bech, M., \& Gyrd-Hansen, D. (2005). Effects coding in discrete choice experiments. Health Economics, 14(10), 1079-1083. doi:https://doi.org/10.1002/hec.984

Bech, M., Kjaer, T., \& Lauridsen, J. (2011). Does the number of choice sets matter? Results from a web survey applying a discrete choice experiment. Health Economics, 20(3), 273-286. doi:https://doi.org/10.1002/hec.1587

Blanken, K., De Buisonje, F., Evers, A. G., Ouweltjes, W., Verkaik, J. C., Vermeij, I., \& Wemmenhove, H. (2017). KWIN 2017 - 2018: Wageningen UR Livestock Research.

Blanken, K., De Buisonje, F., Everts, A., Holster, H., Ouweltjes, W., Verkaik, J. C., ... Wemmenhove, H. (2020). KWIN 2020-2021.

Blasch, J., van der Kroon, B., van Beukering, P., Munster, R., Fabiani, S., Nino, P., \& Vanino, S. (2020). Farmer preferences for adopting precision farming technologies: a case study from Italy. European Review of Agricultural Economics. doi:https://doi.org/10.1093/erae/jbaa031

Brehm, J., \& Rahn, W. (1997). Individual-Level Evidence for the Causes and Consequences of Social Capital. American Journal of Political Science, 41(3), 999-1023. doi:https://doi.org/10.2307/2111684

Cambra-López, M., Aarnink, A. J. A., Zhao, Y., Calvet, S., \& Torres, A. G. (2010). Airborne particulate matter from livestock production systems: A review of an air pollution problem. Environmental Pollution, 158(1), 1-17. doi:https://doi.org/10.1016/j.envpol.2009.07.011

Campbell, D., \& Erdem, S. (2019). Including opt-out options in discrete choice experiments: issues to consider. The Patient-Patient-Centered Outcomes Research, 12(1), 1-14. doi:https://doi.org/10.1007/s40271-018-0324-6

Carey, J. M., \& Zilberman, D. (2002). A Model of Investment under Uncertainty: Modern Irrigation Technology and Emerging Markets in Water. American Journal of Agricultural Economics, 84(1), 171-183. doi:https://doi.org/10.1111/1467-8276.00251

Chèze, B., David, M., \& Martinet, V. (2020). Understanding farmers' reluctance to reduce pesticide use: A choice experiment. Ecological Economics, 167, 106349. doi:https://doi.org/10.1016/j.ecolecon.2019.06.004

Dunkler, D., Plischke, M., Leffondré, K., \& Heinze, G. (2014). Augmented Backward Elimination: A Pragmatic and Purposeful Way to Develop Statistical Models. PLoS One, 9(11), e113677. doi:https://doi.org/10.1371/journal.pone.0113677

Dutch Ministry of Infrastructure and Water Management. Besluit emissiearme huisvesting, W14.15.0152 C.F.R. (2017).

Dutch Ministry of Infrastructure and Water Management. (2019). Clean air agreement. Rijksoverheid Retrieved from https://www.rijksoverheid.nl/documenten/convenanten/2020/01/13/bijlage1-schone-lucht-akkoord. 
Preferences for investments in $\mathrm{PM}_{10}$ abatement techniques

European Council Directive. Directive 2008/50/EC of the European Parliament and of the Council of 21 May 2008 on ambient air quality and cleaner air for Europe, 226/2008 C.F.R. (2008).

European Environment Agency. (2020a). Exceedance of air quality standards in Europe. Retrieved from https://www.eea.europa.eu/data-andmaps/indicators/exceedance-of-air-quality-limit-2/assessment

European Environment Agency. (2020b). National emissions reported to the Convention on Long-range Transboundary Air Pollution (LRTAP Convention). Retrieved from: https://www.eea.europa.eu/data-andmaps/data/national-emissions-reported-to-the-convention-on-long-rangetransboundary-air-pollution-lrtap-convention-14

European Environment Agency. (2021). Exceedance of air quality standards in Europe. Retrieved from https://www.eea.europa.eu/data-andmaps/indicators/exceedance-of-air-quality-limit-2/assessment

Expertise Centre Infomil. (2019). Emission factors per animal - particulate matter. Retrieved from https://www.infomil.nl/onderwerpen/landbouw/stalsystemen/emissiefactor en-per/map-staltypen/7-additionele/

Gocsik, É., Van der Lans, I. A., Oude Lansink, A. G. J. M., \& Saatkamp, H. W. (2015). Willingness of Dutch broiler and pig farmers to convert to production systems with improved welfare. Animal Welfare, 24(2), 211222. doi:https://doi.org/10.7120/09627286.24.2.211

Grantz, D. A., Garner, J. H. B., \& Johnson, D. W. (2003). Ecological effects of particulate matter. Environment international, 29(2), 213-239. doi:https://doi.org/10.1016/S0160-4120(02)00181-2

Hansson, H., \& Sok, J. (2021). Perceived obstacles for business development: Construct development and the impact of farmers' personal values and personality profile in the Swedish agricultural context. Journal of Rural Studies, 81, 17-26. doi:https://doi.org/10.1016/j.jrurstud.2020.12.004

Homidan, A. A., Robertson, J. F., \& Petchey, A. M. (2003). Review of the effect of ammonia and dust concentrations on broiler performance. World's Poultry Science Journal, 59(3), 340-349. doi:https://doi.org/10.1079/WPS20030021

Hudson, D., \& Lusk, J. (2004). Risk and Transactions Cost in Contracting: Results from a Choice-Based Experiment. Journal of Agricultural \& Food Industrial Organization, 2(1). doi:https://doi.org/10.2202/1542-0485.1046

Isik, M. (2004). Incentives for Technology Adoption Under Environmental Policy Uncertainty: Implications for Green Payment Programs. Environmental and Resource Economics, 27(3), 247-263. doi:https://doi.org/10.1023/B:EARE.0000017624.07757.3f

Johnson, R., \& Orme, B. (2003). Getting the most from CBC. Sequim: Sawtooth Software Research Paper Series, Sawtooth Software.

Joshi, P. K., Khan, M. T., \& Kishore, A. (2019). Heterogeneity in male and female farmers' preference for a profit-enhancing and labor-saving technology: 


\section{Chapter 5}

The case of Direct-Seeded Rice (DSR) in India. Canadian Journal of Agricultural Economics, 67(3), 303-320. doi:10.1111/cjag.12205

Keele, L. (2007). Social Capital and the Dynamics of Trust in Government. American Journal of Political Science, 51(2), 241-254. doi:https://doi.org/10.1111/j.1540-5907.2007.00248.x

Lagerkvist, C. J. (2005). Agricultural policy uncertainty and farm level adjustments - the case of direct payments and incentives for farmland investment. European Review of Agricultural Economics, 32(1), 1-23. doi:https://doi.org/10.1093/erae/jbi005

Lammel, G., Schneider, F., Brüggemann, E., Gnauk, T., Röhrl, A., \& Wieser, P. (2004). Aerosols Emitted from a Livestock Farm in Southern Germany. Water, Air, and Soil Pollution, 154(1), 313-330. doi:https://doi.org/10.1023/B:WATE.0000022962.65942.4b

Lancaster, K. J. (1966). A New Approach to Consumer Theory. Journal of Political Economy, 74(2), 132-157. doi:https://doi.org/10.1086/259131

Lancsar, E., Louviere, J., \& Flynn, T. (2007). Several methods to investigate relative attribute impact in stated preference experiments. Social Science \& Medicine, 64(8), 1738-1753. doi:https://doi.org/10.1016/j.socscimed.2006.12.007

Long, T. B., Blok, V., \& Coninx, I. (2016). Barriers to the adoption and diffusion of technological innovations for climate-smart agriculture in Europe: evidence from the Netherlands, France, Switzerland and Italy. Journal of Cleaner Production, 112, 9-21. doi:https://doi.org/10.1016/j.jclepro.2015.06.044

Mangham, L. J., Hanson, K., \& McPake, B. (2008). How to do (or not to do) ... Designing a discrete choice experiment for application in a low-income country. Health Policy and Planning, 24(2), 151-158. doi:https://doi.org/10.1093/heapol/czn047

Mazzanti, M. (2003). Discrete choice models and valuation experiments. Journal of Economic Studies, 30(5/6), 584-604. doi:http://dx.doi.org/10.1108/01443580310504453

McFadden, D. (1974). The measurement of urban travel demand. Journal of Public Economics, 3(4), 303-328. doi:https://doi.org/10.1016/00472727(74)90003-6

McFadden, D. (1979). Quantitative methods for analysing travel behaviour of individuals: some recent developments: Routledge.

Netherlands Enterprise Agency. (2020). Investing in innovative techniques in animal husbandry. Retrieved from https://www.rvo.nl/subsidie-enfinancieringswijzer/innovatie-en-verduurzaming-stallen

Orme, B. (1998). Sample size issues for conjoint analysis studies. Sequim: Sawtooth Software Technical Paper.

Raedts, P. J. M., Garcia, S. C., Chapman, D. F., Edwards, G. R., Lane, N., \& Rawnsley, R. P. (2017). Is systems research addressing the current and future needs of dairy farms? Animal Production Science, 57(7), 1311-1322. doi:https://doi.org/10.1071/AN16647 
Preferences for investments in $\mathrm{PM}_{10}$ abatement techniques

Sawtooth Software. (2021a). Conditional pricing. Retrieved from https://sawtoothsoftware.com/help/lighthousestudio/manual/hid web cbc cp.html

Sawtooth Software. (2021b). Sawtooth software version 4.4.6. Provo: Sawtooth Software. Retrieved from https://sawtoothsoftware.com/

Seedorf, J. (2004). An emission inventory of livestock-related bioaerosols for Lower Saxony, Germany. Atmospheric Environment, 38(38), 6565-6581. doi:https://doi.org/10.1016/j.atmosenv.2004.08.023

Stadig, L. (2019). Vleeskuikenconcepten in Nederland. Retrieved from https:/www.pluimveeloket.be/sites/default/files/inline-files/2019-1010\%20Welzijnsvergelijking\%20vleeskuikenconcepten.pdf

StataCorp. (2019). Stata Statistical Software: Release 16. College Station, TX: StataCorp LP.

TNO. (2019). Factsheet emissies en depositie van stikstof in Nederland. Retrieved from The Hague:

https://publications.tno.nl/publication/34634850/8Pywsn/TNO-2019emissies.pdf

United States Environmental Protection Agency. (2020). Particulate Matter (Raedts et al.) Basics. Retrieved from https://www.epa.gov/pmpollution/particulate-matter-pm-basics

Van de Gucht, T., Saeys, W., Van nuffel, A., Pluym, L., Piccart, K., Lauwers, L., . . . Van weyenberg, S. (2017). Farmers' preferences for automatic lamenessdetection systems in dairy cattle. Journal of dairy science, 100(7), 57465757. doi:10.3168/jds.2016-12285

Vissers, L. S. M., Oude Lansink, A. G. J. M., \& Saatkamp, H. W. (2021). Exploring the performance of system changes in Dutch broiler production to balance animal welfare, ammonia emissions and particulate matter emissions with farm profitability. Agricultural Systems, 193. doi:https://doi.org/10.1016/j.agsy.2021.103217

Wageningen Economic Research. (2021). Dutch FADN, agriculture. Retrieved from

https:/www.agrimatie.nl/themaResultaat.aspx?subpubID=2232\&sectorID $=2258 \&$ themaID $=2265 \&$ indicatorID $=2009$

Zemo, K. H., \& Termansen, M. (2018). Farmers' willingness to participate in collective biogas investment: A discrete choice experiment study. Resource and Energy Economics, 52, 87-101.

doi:https://doi.org/10.1016/j.reseneeco.2017.12.001 


\section{Chapter 6}

General discussion 


\section{Chapter 6}

\subsection{Introduction}

As of the early '70s, societal concerns emerged among European Union (EU) citizens about the negative impact of intensive livestock production on the welfare of farmed animals (Miele et al., 2013). In the past two decades, EU citizens also expressed widespread concerns about the loss of biodiversity, air quality, the environment and food safety (Eurobarometer, 2013, 2015, 2017, 2019b). Broiler production is a source of these concerns as it is responsible for around $10 \%$ of total particulate matter emissions and 3\% of total ammonia emissions originating from agriculture in the EU (European Environment Agency, 2020b). Furthermore, residues of antibiotics in poultry meat are considered one of the possible causes of antibacterial resistance in human pathogens (Muaz et al., 2018). To counteract the societal critique on livestock production, the EU passed legislation on animal welfare (AW), food safety and the environment in the early 2000s (European Council Directive, 1998, 2000, 2001). However, this legislation was deemed insufficient as societal critique persisted in the past 15 years (Eurobarometer, 2005, $2015,2019 b)$. To address the critique related to AW, stakeholders in broiler supply chains introduced more extensive systems including slower-growing broiler strains in the Dutch broiler market. However, broilers reared in these systems have a higher potential to contribute to acidification and eutrophication compared to broilers reared in intensive systems (Leinonen et al., 2012). This finding suggests that switching from conventional to more extensive systems addresses AW concerns but increases environmental concerns.

The changes implemented in these systems yield synergies and trade-offs between externalities, which may affect production costs and/or consumer willingness-topay (see Chapter 1). As the Dutch broiler market is characterized by small profit margins (Van Horne, 2020a), small changes in the production system can have a large impact on farm income. Exploiting synergies and minimizing trade-offs between externalities can therefore have a major contribution to the development of broiler production systems that address multiple externalities. However, knowledge about the contribution of individual system changes on externalities is scattered across research domains and has not been assessed together. Therefore, the existing literature does not provide insight into the contribution of individual system changes on multiple externalities, including the synergies and trade-offs between these externalities. Furthermore, the existing literature does not provide insight into the factors that determine farmers' willingness to invest in more sustainable broiler production systems. To fill these gaps in the literature, the 
overall objective of this dissertation was to explore broiler production systems that address multiple externalities and are aligned with farmers' preferences. The overall objective was decomposed into four sub-objectives which were addressed in Chapters 2-5. Chapter 2 developed a conceptual framework to analyze the implementation of multiple standards that aim to address externalities of meat production. This framework provided a scientific basis for the analysis of synergies and trade-offs between externalities. The framework was applied to the case of the new Dutch retail standard (NDRS), a more stringent standard on AW. Chapter 3 analyzed synergies and trade-offs between externalities in Dutch broiler production systems. Chapter 4 explored the performance of combinations of system changes that lower multiple externalities. Three externalities were considered, i.e. AW, ammonia $\left(\mathrm{NH}_{3}\right)$ emissions and particulate matter $\left(\mathrm{PM}_{10}\right)$ emissions. Chapter 5 measured broiler farmers' preferences for investments in different $\mathrm{PM}_{10}$ abatement techniques. The remainder of the current chapter synthesizes the results, elaborates on the business and policy implications, reflects on the data and methods, outlines directions for future research and ends with the main conclusions of this dissertation.

\subsection{Synthesis}

In the current economic and political environment in the EU, AW concerns are addressed through beyond legal requirements (Lundmark et al., 2018), whereas environmental and human health related concerns are addressed through legal requirements (European Council Directive, 2016; Directive, 2019). Eurobarometer (2016, 2017, 2019a) surveys show that EU legislation on AW, the environment and air quality lag behind societal preferences. Therefore, broiler production systems that mitigate AW concerns, environmental concerns and human health concerns will most likely be implemented in a beyond legal setting, i.e. in a private standard that is yet to be developed ${ }^{1}$. Table 6.1 provides an example of a private standard in broiler production. Such a standard usually increases production costs due to higher input prices and/or a lower production efficiency at farm level. The framework developed in Chapter 2 assumed that the following conditions have to be satisfied for a private standard to be economically feasible: 1) producer profits are not decreasing 2) retailer profits are not decreasing and 3) the increase in willingness to

\footnotetext{
${ }^{1}$ A private standard is a standard developed and adopted by private bodies (Henson \& Humphrey, 2010). According to Swinnen et al. (2015), a standard can be defined as requirements relating to inputs, production processes or final products that can solve market failure related to production or consumption externalities.
} 


\section{Chapter 6}

pay equals or exceeds the increase in consumer price. Gocsik et al. (2015) and Wilson and Hart (2000) underline the necessity of a financial compensation to incentivize farmers to adopt standards that increase production costs. The findings in Chapter 5 showed that the provision of a subsidy was among the main determinants of farmers' preferences for $\mathrm{PM}_{10}$ abatement techniques. This finding supports the assumption that farmers are only willing to adopt a more stringent standard if the additional costs are compensated. Chapter 5 also showed that farmers' preferences for $\mathrm{PM}_{10}$ abatement techniques were critically determined by an exemption from future $\mathrm{PM}_{10}$ emission legislation. This finding implies that not only a financial compensation, but also certainty about future emission legislation should be provided to incentivize farmers to adopt a more stringent environmental standard.

The framework developed in Chapter 2 conceptualizes how synergies and tradeoffs between externalities affect the economic feasibility of a private standard, and serves as a theoretical basis for analyzing synergies and trade-offs. Chapter 3 studied the synergies and trade-offs between externalities in Dutch broiler production systems in detail. The findings showed that the shift from a fastgrowing breed towards a slower-growing breed caused synergy on AW and antibiotic use (see columns 3 and 6, Table 6.1). This finding is supported by Dawkins (2017) and De Passillé and Rushen (2005), who found that AW improvements can reduce antibiotic use through reduced stress-induced immunosuppression and a reduced incidence of diseases. Furthermore, the results in Chapter 3 indicated that a reduction of the crude protein content in feed and a reduction in stocking density enhanced AW and did not necessarily cause a tradeoff with $\mathrm{NH}_{3}$ emissions (see columns 3 and 4, Table 6.1). These findings are consistent with those of Leinonen and Kyriazakis (2016), who found that AW improvements in broiler production can be achieved without elevating the acidification potential. The findings in Chapter 3 further showed that nearly all AW improvements caused a trade-off with $\mathrm{PM}_{10}$ emissions (expressed per animal place per year). This trade-off can be explained by the general positive effect of AW improvements on broiler activity. A higher activity increases dust production, causing higher $\mathrm{PM}_{10}$ concentrations and emission rates (Calvet et al., 2009; Peña Fernández et al., 2019). 
General discussion

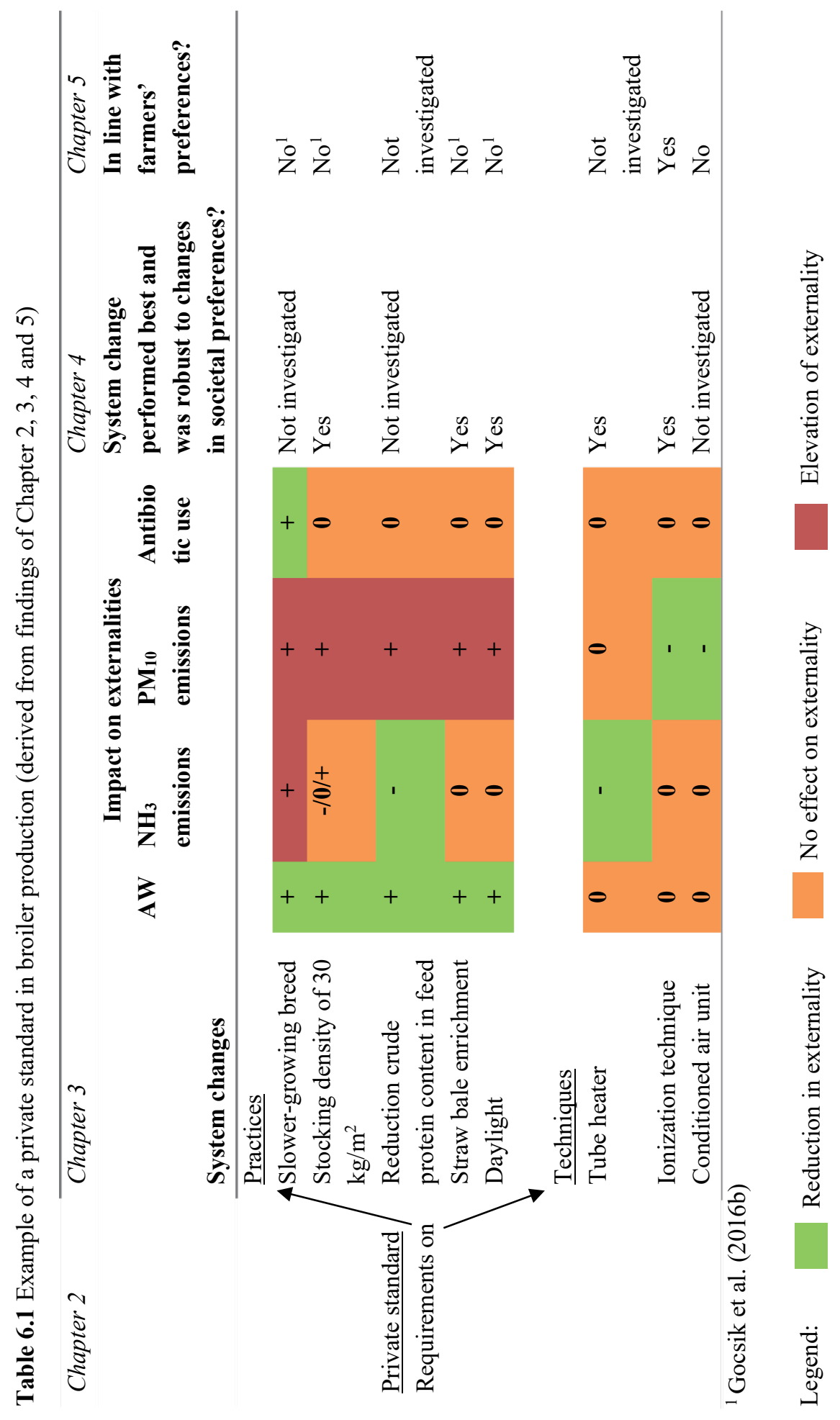




\section{Chapter 6}

From Chapter 3 it appeared that the system changes implemented in the NDRS system and Extensive Indoor+ system, on aggregate, elevated $\mathrm{NH}_{3}$ and $\mathrm{PM}_{10}$ emissions (expressed per animal place per year). These systems have a higher standard on AW compared to the conventional system. Experts estimated that the elevated $\mathrm{NH}_{3}$ and $\mathrm{PM}_{10}$ emissions were partly (NDRS) or fully (Extensive Indoor+) offset at farm level via a lower stocking density. Chapter 2 analyzed the societal benefits and costs associated with the introduction of the NDRS system. In 20142015, this system replaced the conventional system in the Dutch fresh meat market (Saatkamp et al., 2019). Findings in Chapter 2 showed that this replacement increased societal benefits due to reduced antibiotic use. Societal costs associated with $\mathrm{NH}_{3}$ and $\mathrm{PM}_{10}$ emissions increased slightly. This finding can be explained by the fact that the total broiler volume decreased in the Netherlands (Agrimatie, 2021), as the NDRS system requires more surface per animal relative to the conventional system. Therefore, the elevated $\mathrm{NH}_{3}$ and $\mathrm{PM}_{10}$ emissions per broiler were partly offset at a national level.

Chapter 4 builds further on the findings of Chapter 3 by exploring the performance of combinations of system changes in terms of externalities and farm income. Furthermore, this chapter explored the extent to which these combinations were robust to changes in the relative importance society places in these externalities. Three externalities were considered, i.e. $\mathrm{AW}, \mathrm{NH}_{3}$ emissions and $\mathrm{PM}_{10}$ emissions. The system changes encompass $\mathrm{AW}$-enhancing practices, $\mathrm{NH}_{3}$ abatement techniques and $\mathrm{PM}_{10}$ abatement techniques. A combination of system changes performed best when it reduced the externalities by a certain level with a minimum decrease in farm income. The best performing and robust combinations considerably improved $\mathrm{AW}$, and lowered both $\mathrm{NH}_{3}$ emissions (between $66 \%$ and $73 \%$ ) and $\mathrm{PM}_{10}$ emissions (between $41 \%$ and $61 \%$ ). A relatively small (5\%) to substantial $(19 \%)$ increase in the producer price was required to compensate for the decrease in farm income associated with these combinations (in line with the condition of income-neutrality in Chapter 2).

The results in Chapter 4 showed that the best performing and robust combinations included two or more of the following AW-enhancing practices: a lower stocking density $\left(30 \mathrm{~kg} / \mathrm{m}^{2}\right)$, provision of enrichment and/or the provision of daylight (see column 7, Table 6.1). A lower stocking density may cause a synergy with $\mathrm{NH}_{3}$ emissions, while provision of enrichment and daylight do not affect $\mathrm{NH}_{3}$ emissions. The system changes cause a trade-off with $\mathrm{PM}_{10}$ emissions. The findings in Chapter 4 are consistent with the results of Vissers et al. (2019). These 
authors found that a reduction in stocking density, and the provision of enrichment and daylight are relatively cost-efficient, i.e. improve AW at a relatively small increase in production costs. The question is whether the best performing systems changes are aligned with farmer preferences. Gocsik et al. (2016b) found that Dutch broiler farmers preferred conventional practices and had no intrinsic motivation to switch to a system that includes AW-enhancing practices. It should be noted that conventional broiler farmers were the main target group in this study ( $96 \%$ of the sample). Currently, about $60 \%$ of the broilers are produced in conventional systems (Van Horne, 2020b). Therefore, the preferences of conventional broiler farmers may not be representative for the whole population of Dutch broiler farmers. The best performing combinations of system changes also included tube heaters to reduce $\mathrm{NH}_{3}$ emissions and an ionization technique to reduce $\mathrm{PM}_{10}$ emissions (see column 7, Table 6.1). The findings in Chapter 5 showed that farmers had a general preference for ionization techniques to reduce $\mathrm{PM}_{10}$ emissions (see column 8, Table 6.1). Farmers that operated on a large scale ( $>60,000$ broilers) had a lower preference for these techniques. Findings in Chapter 5 indicated that in general, farmers were reluctant to invest in $\mathrm{PM}_{10}$ abatement techniques. This result may be explained by the fact that $\mathrm{PM}_{10}$ abatement techniques lead to an increase of the production costs, which are not compensated by an output price premium. Therefore, farmers have a financial disincentive to invest in these techniques. Results in Chapter 5 revealed a high heterogeneity in farmers' preferences for investments in $\mathrm{PM}_{10}$ abatement techniques, which could be explained by both socio-economic factors (e.g. age of the farmer) and perceived obstacles for business development (e.g. rules and regulation).

From the findings of this dissertation, a general picture of the potential for sustainable broiler production systems emerges. The findings indicate that there are prospects for the development of broiler production systems that improve AW, reduce environmental emissions, and reduce risks relating to human health. To compensate for the decrease in farm income associated with the system changes, an increase in the producer price is required that ranges from relatively small (5\%) to substantial (19\%). Although AW improvements may elevate $\mathrm{NH}_{3}$ and $\mathrm{PM}_{10}$ emissions per animal, these emissions can be partly or fully offset at farm level via a lower stocking density. Furthermore, there are techniques available that mitigate $\mathrm{NH}_{3}$ and $\mathrm{PM}_{10}$ emissions in an income-efficient manner. Farmers expressed a negative willingness to invest in $\mathrm{PM}_{10}$ abatement techniques. The likelihood that farmers invest in $\mathrm{PM}_{10}$ abatement techniques can be increased through providing 


\section{Chapter 6}

subsidy and an exemption from future legislation. These insights could provide guidelines for the development of sustainable broiler production systems in the next ten years.

\subsection{Limitations in data, theory and methods}

The limitations in the data, theory and methods had consequences for the interpretation of the results. In the following, these limitations are discussed.

\subsubsection{Data}

A simulation model was developed for Chapter 3 to estimate the externalities and farm income generated from the conventional, NDRS and Extensive Indoor+ system. This model required economic data, $\mathrm{AW}$ data and data on $\mathrm{NH}_{3}$ and $\mathrm{PM}_{10}$ emissions in these systems. Economic data and AW data were available for the conventional, NDRS and Extensive Indoor+ system. However, data on $\mathrm{NH}_{3}$ and $\mathrm{PM}_{10}$ emissions were lacking for the NDRS and Extensive Indoor+ system. Expert Knowledge Elicitation (EKE) was used to estimate the $\mathrm{NH}_{3}$ and $\mathrm{PM}_{10}$ emissions originating from these systems. EKE is often used in the literature to address uncertainty about parameters in environmental models and to obtain parameter estimates in situations where data is lacking (see e.g. Ali et al. (2021) and Pashaei Kamali (2015)). However, EKE is less suitable for precise estimations of $\mathrm{NH}_{3}$ and $\mathrm{PM}_{10}$ emissions as they are affected by many external factors (e.g. air temperature) (Ellen \& Ogink, 2015). Therefore, the results in Chapter 3 do not allow precise insight into the $\mathrm{NH}_{3}$ and $\mathrm{PM}_{10}$ emissions originating from these systems. EKE is more suitable for estimation of the ranking of systems based on their emissions, particularly if it is carried out together with a thorough sensitivity analysis on ranking robustness. The sensitivity analysis in Chapter 3 showed that the ranking of the systems, based on emitted $\mathrm{NH}_{3}$ and $\mathrm{PM}_{10}$ in $\mathrm{kg}$ per farm per year, was largely unaffected. Therefore, the results were robust to changes in the $\mathrm{NH}_{3}$ and $\mathrm{PM}_{10}$ emission factor of the NDRS and Extensive Indoor+ system.

The simulation model developed in Chapter 3 was used in Chapter 4 to estimate the impact of combinations of system changes on farm income, $\mathrm{AW}, \mathrm{NH}_{3}$ emissions and $\mathrm{PM}_{10}$ emissions. To improve the accuracy of the model estimates, data was required about the effect of $\mathrm{AW}$-related system changes on $\mathrm{NH}_{3}$ and $\mathrm{PM}_{10}$ emissions. As before, EKE was used to estimate these effects. However, the experts indicated that they could only assess these effects in qualitative terms. The experts thought that $\mathrm{NH}_{3}$ and $\mathrm{PM}_{10}$ emissions are affected by many external factors (e.g. air temperature). For this reason, it was not possible to include the effects of 
AW-related system changes on $\mathrm{NH}_{3}$ and $\mathrm{PM}_{10}$ emissions in the model. The qualitative estimations showed that AW-related system changes, in general, elevate $\mathrm{NH}_{3}$ and $\mathrm{PM}_{10}$ emissions (expressed per animal place per year). Therefore, the exclusion of these effects implies that the potential to reduce $\mathrm{NH}_{3}$ and $\mathrm{PM}_{10}$ emissions in broiler production systems is most likely overestimated. However, as this shortcoming affected all explored combinations of system changes in the same way, the relative differences between the combinations are most likely small.

For Chapter 5, a questionnaire was carried out to analyze broiler farmers' preferences for investments in different $\mathrm{PM}_{10}$ abatement techniques. In total, 63 broilers farmers participated in the questionnaire, which is $10 \%$ of the total population of Dutch broiler farmers (Agrimatie, 2020). This sample size is rather small for discrete choice experiment studies. De Bekker-Grob et al. (2015) investigated the sample size of discrete choice experiment studies. Most studies (41\%) had sample sizes between 100 and 300 respondents, followed by studies (32\%) that had sample sizes smaller than 100 respondents. The remainder (27\%) had sample sizes larger than 300 respondents. A small sample size is a common drawback in discrete choice experiment studies targeting farmers, because this population is asked frequently to participate in questionnaires, leading to an increasing reluctance to participate. Moreover, environmental measures are a sensitive topic among Dutch farmers. The sample size (63 respondents) satisfied the minimum sample size (50 respondents) required for analyzing the main effects of the choice attributes (see Orme (1998) and Johnson and Orme (2003)). It was not possible to estimate higher order interaction effects as the analysis of these effects requires a substantial larger sample size (De Bekker-Grob et al., 2015).

\subsubsection{Theory and methods}

In the framework developed in Chapter 2, it was assumed that a private standard is economically feasible only if it does not lower farm profits, retailer profits and the utility of consumers. Various studies show that in addition to maximizing profits, farmers may have other goals such as gaining recognition as a farmer or continuing the family tradition (Gasson, 1973; Ferguson \& Hansson, 2013; Howley, 2015). These goals may vary between individuals and for the same individuals at different stages in their careers (Gasson, 1973). Gocsik et al. (2015) found that Dutch broiler farmers are only willing to convert to more AW-friendly systems if it does not lower their income. This finding suggests that income-neutrality is a minimum condition. If this condition is satisfied, most broiler farmers are in principle willing to adopt a more stringent standard (Gocsik et al., 2015). 


\section{Chapter 6}

In Chapter 3, only emissions were considered that originate primarily from the broiler house. Because of this criterion, some environmental emissions (such as greenhouse gases ${ }^{2}$ ) were not considered. Therefore, the findings do not provide insight into the synergies and trade-offs between all environmental emissions. In Chapters 3 and 4, the emissions were considered only at farm gate. Therefore, this study does not provide insight into the effect of more sustainable broiler production systems on total environmental emissions of broiler supply chains.

In Chapters 3 and 4, the farm income generated from broiler production systems was indicated by the net return to labor and management (total revenues minus total costs excluding labor costs). This indicator does not take into account the financial situation of the farm, such as the farms' solvency ratio. As the financial situation of the farm is ignored, the findings do not provide insight into the midterm and long-term feasibility of more sustainable broiler production systems. At the start of the transition towards this system, the financial situation might influence the short-run capability of the farm coping with financial drawbacks (e.g. low output prices). As the dissertation focused on the effect of more sustainable broiler production systems on externalities and farm income, the mid-term and long-term feasibility of these systems was beyond the scope of this dissertation. Another shortcoming is that the findings in Chapter 3 and 4 represent only average Dutch broiler farms. However, it should be noted that the parameters of the model can be adjusted to reflect other types of broiler farms and the findings are also relevant to other North-West European countries, such as Germany and Belgium. Citizens of these countries also expressed widespread concerns about AW, the environment and human health (Eurobarometer, 2013, 2015, 2017, 2019b).

In Chapter 4, the benefit-of-the-doubt method was used to aggregate the subindicators, i.e. $\mathrm{AW}, \mathrm{PM}_{10}$ emissions, $\mathrm{NH}_{3}$ emissions and net return to labor and management, into a composite indicator. The benefit-of-the-doubt method was selected for two reasons. First, the benchmark is not based upon theoretical bounds but on a linear combination of observed best performing combinations of measures (OECD, 2008). As our study explores the performance of system changes, a benchmark based on best performers fits the purpose of our research better than a benchmark based upon theoretical bounds. Second, the benefit-of-the doubt is a flexible method that allows weights to vary across observations (Cherchye et al.,

\footnotetext{
${ }^{2}$ Broiler houses are only a minor source (less than $10 \%$ ) of the greenhouse gasses emitted in broiler supply chains (Gerber et al., 2013).
} 
2007). Experts that participated in the EKE were not able to indicate which externality would be the key driver in the development of Dutch broiler production systems in the next ten years. When experts are uncertain or disagree about the right set of weights, the benefit-of-the-doubt method is sufficiently flexible to incorporate 'agreed judgements' by imposing additional weight restrictions (Cherchye et al., 2007). These weight restrictions can be adjusted to test the robustness of the performance scores to changes in the weights assigned to the subindicators.

In Chapter 5, a discrete choice experiment was conducted to measure broiler farmers' preferences for investments in different $\mathrm{PM}_{10}$ abatement techniques. This method was used as it allows the inclusion of a price attribute in the experimental design. In the experiment, the investment amount of the $\mathrm{PM}_{10}$ abatement technique was selected as the price attribute. This attribute is relevant as earlier research of Blasch et al. (2020) and Long et al. (2016) showed that the initial investment outlay is an important determinant of farmers' willingness to adopt new technologies. A price attribute is not possible, or not recommended in other methods that elicit individuals' preferences (Sawtooth Software, 2018).

The beforementioned limitations should be taken into account when interpreting the results. An important question is how these limitations affected the general picture described in the synthesis (section 6.2). First, the results do not allow precise insight into the $\mathrm{NH}_{3}$ and $\mathrm{PM}_{10}$ emissions originating from the NDRS and Extensive Indoor+ system, and the potential to mitigate these emissions in new broiler production systems. However, the results provide insight into the ranking of systems based on their emissions and the relative performance of system changes that address $\mathrm{NH}_{3}$ and $\mathrm{PM}_{10}$ emissions. Second, the findings shed light on the impact of these system changes on farm income but do not provide insight into the longterm feasibility of systems that include these changes. Third, the results provide insight into farmers' preferences for investments in different $\mathrm{PM}_{10}$ abatement techniques and the relations with socio-economic demographics and perceived obstacles for business development. However, these findings may not be representative for the whole population of Dutch broiler farmers as the sample size was relatively small.

\subsection{Business and policy implications}

As discussed in section 6.2, a more sustainable broiler production system will most likely be implemented through a private standard. According to Buurma et al. 


\section{Chapter 6}

(2017), the introduction of such a standard requires involvement of all stakeholders in the supply chain. The remainder of this subsection discusses the role of various stakeholders in private standards.

\section{Broiler farmers}

The adoption of a private standard is a voluntary choice of the farmer, which usually increases production costs. Gocsik et al. (2015) show that farmers are only willing to adopt a more stringent $\mathrm{AW}$-standard if the additional costs are compensated by a price premium, i.e. it does not lower their income. The findings in Chapter 3 and 4 showed which system changes address $\mathrm{AW}$ and $\mathrm{NH}_{3}$ and $\mathrm{PM}_{10}$ emissions in an income-efficient manner and whether these system changes yield synergies or trade-offs between externalities. By exploiting these synergies, multiple externalities can be addressed simultaneously which may lead to a smaller increase in production costs compared to system changes that do not yield synergies. Insight in these synergies can therefore facilitate the development of more sustainable broiler production systems that mitigate multiple externalities. Furthermore, the findings in Chapter 4 indicated which combinations of system changes are robust to changes in the societal attitude towards $\mathrm{AW}, \mathrm{NH}_{3}$ emissions and $\mathrm{PM}_{10}$ emissions. Public outrage about these externalities is usually aroused by news items in the (social) media and may therefore appear sudden. However, the time scale of a transition driven by aroused public opinion on societal issues is usually a decade (Buurma et al., 2017). With the findings of Chapter 4, the sector can anticipate on societal concerns about broiler production when developing new broiler production systems.

\section{Retailers}

As retailers have a pivotal place in broiler supply chains (Saatkamp et al., 2019), they are the most obvious actor to initiate a private standard. To prevent a decrease in the profits of farmers and processors, retailers should offer a premium (e.g. a price premium) to farmers to compensate for the additional costs of the private standard. The standard may require investments in more sustainable broiler production systems and new logistic channels. Currently, the attitude of retailers towards meat products does not encourage investments at farm level. When transitioning towards a different system, farmers often get a contract for 3 years (Van der Meulen et al., 2020). However, this transition often requires investments that have a lifespan of 5-10 years. Due to the strong position of retailers in broiler supply chains, they have the freedom to choose from suppliers offering the lowest price (Van Galen et al., 2020). This generates fierce competition among farmers, 
which forces them to sell products at marginal costs in the short term. Recently, Dutch retailers announced that they will adopt the more stringent AW-standard of the Dutch Society for the Protection of Animals (2021) as of 2023. As part of change, retailers agreed contracts with broiler farmers about the adoption of this standard. This development suggests a change in the attitude of Dutch retailers towards broiler meat.

\section{Consumers}

Economic feasibility of a private standard requires a stable and sufficiently large consumer demand for more sustainable broiler meat. Otherwise, the retailer condition for acceptance of the standard (no decrease in profits, see Chapter 2) may not be satisfied. Eurobarometer $(2015,2016,2019 b)$ surveys show that EU citizens expressed widespread concerns about AW, the environment and human health. These concerns do not necessarily result in a higher demand for more broiler sustainable meat as citizens usually do not choose the more sustainable product when the cheaper, less sustainable product is also on offer (Aerts, 2013). The framework developed in Chapter 2 demonstrated that this issue can be overcome by replacing less sustainable broiler meat by more sustainable broiler meat. As consumer perceptions of more sustainable products are heterogeneous (De Jonge \& Van Trijp, 2014; Jensen et al., 2019), some consumers value more sustainable broiler meat whereas others don't. When replacing less sustainable broiler meat by more sustainable broiler meat, consumers will (most likely) be confronted with a higher price. Therefore, consumers that do not value more sustainable broiler meat may shift towards a different meat product or a meat substitute, which can potentially erode the investments in the private standard. The empirical case of the NDRS (see Chapter 2) showed that this shift does not necessarily occur. Although the consumer price of broiler meat increased by nearly $25 \%$ due to this standard, the demand for broiler meat was virtually non-unaffected $(+0.2 \%)$. These findings were supported by data (Agrimatie, 2021). De Bruyn et al. (2018) found that broiler meat would remain the cheapest meat product when all external costs of meat production would be internalized. This finding suggests that there is a scope for internalizing these costs in broiler production.

\section{Government}

To protect consumer interests, the European competition law forbids private standards that restrict competition between businesses (European Council Directive, 2014). Private standards that contribute to sustainability may be exempted from this law. These standards are assessed by the Netherlands Authority 


\section{Chapter 6}

for Consumers \& Markets (2021) (ACM). The findings in Chapter 2 suggest that the ACM should consider a different response towards such standards as they may be welfare enhancing and can effectively contribute to achieving policy goals. It is possible that private standards that restrict competition between businesses lead to greenwashing, as firms can collectively decide to impose small sustainability improvements against a large increase in consumer price. To prevent greenwashing, certification of standards and surveillance by the government are required.

A private standard that causes synergy between externalities may contribute to multiple policy goals. This can be an argument for the government to facilitate a private standard that is economically not feasible and would not be implemented if it were left to the market. Future research could investigate whether subsidies or fiscal facilities enhance the implementation of private standards. The findings in Chapter 5 imply that policy-makers should aim at reducing uncertainty regarding regulatory outcomes to incentivize farmers to reduce $\mathrm{PM}_{10}$ emissions. A private standard that causes a trade-off may elevate the societal concern related to an externality. This can be an argument for the government to not facilitate the standard. To achieve the policy goal(s), the government could intervene in the broiler market by imposing a meat tax or more stringent legislation.

\section{Chain actors depending on export markets}

Export markets are of great importance for the Dutch broiler meat sector as nearly two-thirds of total Dutch broiler meat is exported abroad (Van Horne, 2020b). Main destinations are the United Kingdom (26\%), Germany (24\%) and France (10\%) (Eurostat, 2020). Cut-up parts such as wings and legs are predominantly exported and in many cases sold as conventional broiler meat (Bokkers \& De Boer, 2009). Foreign demand for more sustainable broiler meat may enhance the economic feasibility of a private standard as the fixed costs of the standard can be spread over a larger sales volume. The question is whether the consumer trends in export markets are similar to those of the Dutch broiler market. The meta-analysis of Li and Kallas (2021) suggest that there is a demand for more sustainable food products in Europe. Willingness-to-pay estimates indicate that European consumers were, on average, willing to pay a price premium around $32 \%$ for more sustainable food products (Li \& Kallas, 2021). The highest willingness-to-pay was for the organic attribute $(38.1 \%)$, followed by fair-trade attributes $(30.5 \%)$, AW attributes (29.5\%), and environmentally friendly attributes $(21.3 \%)$. 
In Europe, a major shift towards more AW-friendly broiler production systems is projected to occur in 2026. In 2026, over 100 leading companies across Europe will adopt the AW-standards of the Better Chicken Commitment (2020). In the Netherlands, more AW-friendly broiler production systems have been already been developed for the domestic market. The logistic channels developed for these systems could be used for new broiler production systems. Therefore, the Dutch broiler sector might have a short-term competitive advantage when introducing more sustainable broiler systems in domestic and export markets.

\subsection{Implications for future research}

This dissertation explored broiler production systems and analyzed the impact of these systems on externalities and farm income. The dissertation considered only the income generated from these systems for one year and did not consider the mid-term and long-term feasibility of a transition towards these systems. Future research could address these issues by considering a period that covers the lifespan of the investments in broiler houses (usually 5-10 years) and including indicators that take into account the financial situation of the farm.

On the basis of EKE, the $\mathrm{NH}_{3}$ and $\mathrm{PM}_{10}$ emissions originating from the NDRS and Extensive Indoor+ system were estimated. These estimations do not provide precise insight into the $\mathrm{NH}_{3}$ and $\mathrm{PM}_{10}$ emissions originating from these systems. To improve decision making in the development of sustainable broiler production systems, future research should measure the $\mathrm{NH}_{3}$ and $\mathrm{PM}_{10}$ emissions originating from these systems.

Due to data limitations, the impact of AW-related system changes on $\mathrm{PM}_{10}$ and $\mathrm{NH}_{3}$ emissions was ignored. This shortcoming implies that the potential to reduce $\mathrm{NH}_{3}$ and $\mathrm{PM}_{10}$ emissions in broiler production systems that include $\mathrm{AW}$-related system changes is most likely overestimated. Future research could assess the contribution of individual $\mathrm{AW}$-improving system changes to environmental emissions.

The framework demonstrates that sufficient demand for more sustainable meat products is an important condition for the economic feasibility of a private standard. The findings of $\mathrm{Li}$ and Kallas (2021) show that, on average, there is a willingness-to-pay for more sustainable food products among European citizens. However, the attitudes of the citizen (as found via surveys) usually differs from that of the consumer (assessed via buying patterns) (Aerts, 2013). Future research 


\section{Chapter 6}

could investigate which policy instruments effectively align the attitudes of the citizen with the attitudes of the consumer. Furthermore, future research should examine at which price consumers switch from broiler meat towards alternative products.

In this dissertation, heterogeneity in farmers' preferences for investments in $\mathrm{PM}_{10}$ abatement techniques was explained by differences in socio-economic characteristics and perceived obstacles for business development. Other factors that could explain this heterogeneity, such as the attitude of farmers towards sustainability, were not considered. Future research could apply an integrated choice and latent variable approach or a reasoned action approach to identify which social-psychological constructs (e.g. attitude or perceived norms) determine farmers' intentions to invest in $\mathrm{PM}_{10}$ abatement techniques.

This dissertation explored only broiler production systems. Other intensive livestock production systems are also an important source of the societal concerns expressed by EU citizens (Steinfeld, 2006; Cambra-López et al., 2010; Broom, 2017). Future research could apply the approaches developed in this dissertation to other livestock production systems to explore the synergy and trade-offs between externalities in these systems and to assess the potential for optimization of these livestock production systems.

\subsection{Conclusions}

- Synergies enhance the economic feasibility of standards that aim to address externalities resulting from meat production, whereas trade-offs hamper the economic feasibility of these standards (Chapter 2).

- Market failure related to production externalities can be successfully addressed by private standards provided that the standard does not lower producer, retailer and consumer welfare (Chapter 2).

- Not only a financial compensation, but also certainty about future emission legislation is an important determinant for the adoption of more stringent environmental standards by Dutch broiler farmers (Chapter 2 and 5).

- In more extensive Dutch broiler production systems, elevated $\mathrm{NH}_{3}$ and $\mathrm{PM}_{10}$ emissions per animal were partly (NDRS) or fully offset (Extensive Indoor+) at farm level due to a reduction in the stocking density (Chapter 3).

- The best performing system changes that enhanced AW caused a trade-off with $\mathrm{PM}_{10}$ emissions, but did not necessarily cause trade-off with $\mathrm{NH}_{3}$ emissions (Chapter 3 and 4). 
- Considerable improvements in AW and considerable reductions in $\mathrm{NH}_{3}$ emissions (66-73\%) and $\mathrm{PM}_{10}$ emissions (41-61\%) can be achieved in the NDRS system at a limited increase in the producer price (5-19\%) (Chapter 4).

- Combinations of system changes that included AW-enhancing management practices, a $\mathrm{NH}_{3}$ abatement technique and a $\mathrm{PM}_{10}$ abatement technique performed best and were robust to potential changes in society's expectations towards externalities (Chapter 4).

- $\mathrm{PM}_{10}$ abatement techniques have the potential to considerably reduce $\mathrm{PM}_{10}$ emissions from broiler houses (up to $80 \%$ ), but broiler farmers are in general reluctant to invest in these techniques (Chapter 4 and 5).

- Farmers have a general preference for techniques with a medium to high $\mathrm{PM}_{10}$ reduction efficiency (31-52\%), rather than techniques with a very high $\mathrm{PM}_{10}$ reduction efficiency (80\%) (Chapter 5).

- Farmers that perceived their financial resources as constraining were less willing to invest in $\mathrm{PM}_{10}$ abatement techniques, whereas farmers that perceived the location of the farm as constraining were more willing to invest in $\mathrm{PM}_{10}$ abatement techniques (Chapter 5). 


\section{Chapter 6}

\section{References}

Aerts, S. (2013). The consumer does not exist: overcoming the citizen/consumer paradox by shifting focus. In The ethics of consumption (pp. 172-176): Springer.

Agrimatie. (2015). Voorzieningsbalansen. Retrieved from https://www.agrimatie.nl/VoorzieningsBalansen.aspx

Agrimatie. (2018). Agrarische prijzen. Retrieved from https://www.agrimatie.nl/Prijzen.aspx?ID=15125

Agrimatie. (2020). Structure Dutch broiler farming. Retrieved from https://www.agrimatie.nl/ThemaResultaat.aspx?subpubID $=2232 \&$ themaID $=2286 \&$ sectorID $=2258 \&$ indicatorID $=2015$

Agrimatie. (2021). Voorzieningsbalansen. Retrieved from https://www.agrimatie.nl/VoorzieningsBalansen.aspx

Albert Heijn. (2018). AH hele kip. Retrieved from https://www.ah.nl/producten/product/wi39978/ah-hele-kip

Ali, B. M., van der Werf, W., \& Oude Lansink, A. (2021). Assessment of the environmental impacts of Xylella fastidiosa subsp. pauca in Puglia. Crop Protection, 142, 105519. doi:https://doi.org/10.1016/j.cropro.2020.105519

Bailie, C. L., Ball, M. E. E., \& O'Connell, N. E. (2013). Influence of the provision of natural light and straw bales on activity levels and leg health in commercial broiler chickens. Animal, 7(4), 618-626. doi:https://doi.org/10.1017/S1751731112002108

Barry, P. J., \& Ellinger, P. N. (2012). Financial Management in Agriculture: Pearson.

Baumol, W. J., Panzar, J., \& Willig, R. (1983). Contestable markets: an uprising in the theory of industry structure. American Economic Review, 73(3), 491496. doi:www.jstor.org/stable/1808145

Bech, M., \& Gyrd-Hansen, D. (2005). Effects coding in discrete choice experiments. Health Economics, 14(10), 1079-1083. doi:https://doi.org/10.1002/hec.984

Bech, M., Kjaer, T., \& Lauridsen, J. (2011). Does the number of choice sets matter? Results from a web survey applying a discrete choice experiment. Health Economics, 20(3), 273-286. doi:https://doi.org/10.1002/hec.1587

Bessei, W. (2006). Welfare of broilers: a review. World's Poultry Science Journal, 62(3), 455-466. doi:https://doi.org/10.1017/S0043933906001085

Better Chicken Commitment. (2020). Better Chicken Commitment. Retrieved from https://betterchickencommitment.com/

Blanken, K., De Buisonje, F., Evers, A. G., Ouweltjes, W., Verkaik, J. C., Vermeij, I., \& Wemmenhove, H. (2017). KWIN 2017 - 2018: Wageningen UR Livestock Research.

Blanken, K., De Buisonje, F., Evers, A. G., Ouweltjes, W., Verkaik, J. C., Vermeij, I., \& Wemmenhove, H. (2019). KWIN 2019-2020: Wageningen University \& Research. 
Blanken, K., De Buisonje, F., Everts, A., Holster, H., Ouweltjes, W., Verkaik, J. C., ... Wemmenhove, H. (2020). KWIN 2020-2021.

Blasch, J., van der Kroon, B., van Beukering, P., Munster, R., Fabiani, S., Nino, P., $\&$ Vanino, S. (2020). Farmer preferences for adopting precision farming technologies: a case study from Italy. European Review of Agricultural Economics. doi:https://doi.org/10.1093/erae/jbaa031

Bokkers, E. A. M., \& De Boer, I. J. M. (2009). Economic, ecological, and social performance of conventional and organic broiler production in the Netherlands. British Poultry Science, 50(5), 546-557. doi:https://doi.org/10.1080/00071660903140999

Bokkers, E. A. M., Van Zanten, H. H. E., \& Van den Brand, H. (2010). Field study on effects of a heat exchanger on broiler performance, energy use, and calculated carbon dioxide emission at commercial broiler farms, and the experiences of farmers using a heat exchanger. Poultry science, 89(12), 2743-2750. doi:https://doi.org/10.3382/ps.2010-00902

Bokma-Bakker, M. H., Wiegel, J., Holstege, M. M. C., Kluivers-Poodt, M., De Lauwere, C. C., \& Bouwstra, R. J. (2017). Onderzoek naar kritische succesfactoren voor een laag antibioticumgebruik bij vleeskuikens: rapport van het project Kritische Succesfactoren Pluimvee (KSF Pluimvee). In Livestock Research rapport, 1570-8616 ; 1065A. Retrieved from https://doi.org/10.18174/427330

Bracke, M. B. M., Koene, P., Estevéz, I., Butterworth, A., \& de Jong, I. C. (2019). Broiler welfare trade-off: A semi-quantitative welfare assessment for optimised welfare improvement based on an expert survey. PLoS One, 14(10), e0222955. doi:https://doi.org/10.1371/journal.pone.0222955

Brehm, J., \& Rahn, W. (1997). Individual-Level Evidence for the Causes and Consequences of Social Capital. American Journal of Political Science, 41(3), 999-1023. doi:https://doi.org/10.2307/2111684

Broom, D. M. (2017). Animal Welfare in the European Union. Retrieved from http://www.europarl.europa.eu/RegData/etudes/STUD/2017/583114/IPOL STU(2017)583114_EN.pdf

Buurma, J., Hennen, W., \& Verwaart, T. (2017). How social unrest started innovations in a food supply chain. Journal of Artificial Societies and Social Simulation, 20(1). doi:https://doi.org/10.18564/jasss.3350

Calhoun, C. J. (2002). Dictionary of the social sciences. In. Retrieved from https://www-oxfordreferencecom.ezproxy.library.wur.nl/view/10.1093/acref/9780195123715.001.0001/ acref-9780195123715

Calvet, S., Van den Weghe, H., Kosch, R., \& Estellés, F. (2009). The influence of the lighting program on broiler activity and dust production. Poultry Science, 88(12), 2504-2511. doi:https://doi.org/10.3382/ps.2009-00255

Cambra-López, M., Aarnink, A. J. A., Zhao, Y., Calvet, S., \& Torres, A. G. (2010). Airborne particulate matter from livestock production systems: A review 


\section{Chapter 6}

of an air pollution problem. Environmental Pollution, 158(1), 1-17. doi:https://doi.org/10.1016/j.envpol.2009.07.011

Cambra-López, M., Winkel, A., Van Harn, J., Ogink, N. W. M., \& Aarnink, A. J. A. (2009). Ionization for reducing particulate matter emissions from poultry houses. Transactions of the ASABE, 52(5), 1757-1771. doi:https://doi.org/10.13031/2013.29138

Campbell, D., \& Erdem, S. (2019). Including opt-out options in discrete choice experiments: issues to consider. The Patient-Patient-Centered Outcomes Research, 12(1), 1-14. doi:https://doi.org/10.1007/s40271-018-0324-6

Carey, J. M., \& Zilberman, D. (2002). A Model of Investment under Uncertainty: Modern Irrigation Technology and Emerging Markets in Water. American Journal of Agricultural Economics, 84(1), 171-183. doi:https://doi.org/10.1111/1467-8276.00251

Castellini, C., Boggia, A., Cortina, C., Dal Bosco, A., Paolotti, L., Novelli, E., \& Mugnai, C. (2012). A multicriteria approach for measuring the sustainability of different poultry production systems. Journal of Cleaner Production, 37, 192-201. doi:https://doi.org/10.1016/j.jclepro.2012.07.006

CBS. (2018). Consumentenprijsindex; 2015=100. Retrieved from: http://statline.cbs.nl/Statweb/publication/?DM=SLNL\&PA=83131NED\& $\mathrm{D} 1=4 \& \mathrm{D} 2=12 \& \mathrm{D} 3=220 \% 2 \mathrm{c} 233 \% 2 \mathrm{c} 246 \% 2 \mathrm{c} 259 \% 2 \mathrm{c} 272 \% 2 \mathrm{c} 285 \& \mathrm{HDR}=$ $\mathrm{T} \& \mathrm{STB}=\mathrm{G} 2 \% 2 \mathrm{cG} 1 \& \mathrm{VW}=\mathrm{T}$

Cherchye, L., Moesen, W., Rogge, N., \& Van Puyenbroeck, T. (2007). An introduction to 'benefit of the doubt' composite indicators. Social Indicators Research, 82(1), 111-145. doi:https://doi.org/10.1007/s11205006-9029-7

Chèze, B., David, M., \& Martinet, V. (2020). Understanding farmers' reluctance to reduce pesticide use: A choice experiment. Ecological Economics, 167, 106349. doi:https://doi.org/10.1016/j.ecolecon.2019.06.004

Dawkins, M. S. (2017). Animal welfare and efficient farming: is conflict inevitable? Animal Production Science, 57(2), 201-208. doi:https://doi.org/10.1071/AN15383

De Bekker-Grob, E. W., Donkers, B., Jonker, M. F., \& Stolk, E. A. (2015). Sample Size Requirements for Discrete-Choice Experiments in Healthcare: a Practical Guide. The Patient - Patient-Centered Outcomes Research, 8(5), 373-384. doi:https://doi.org/10.1007/s40271-015-0118-z

De Bruyn, S., Odegard, I., \& Warringa, G. (2018). De echte prijs van vlees. Retrieved from https://www.ce.nl/publicaties/2091/de-echte-prijs-van$\underline{\text { vlees }}$

De Jong, I. C., \& Gunnink, H. (2019). Effects of a commercial broiler enrichment programme with or without natural light on behaviour and other welfare indicators. animal, 13(2), 384-391. doi:10.1017/S1751731118001805

De Jong, I. C., Gunnink, H., \& Hindle, V. A. (2015). Implementation of the Welfare Quality broiler assessment protocol-final report: overview of outcome-based measurement of broiler welfare and a general discussion 
on the Welfare Quality broiler assessment protocol. Retrieved from https://library.wur.nl/WebQuery/wurpubs/486781

De Jonge, J., \& Van Trijp, H. C. M. (2013). Meeting heterogeneity in consumer demand for animal welfare: A reflection on existing knowledge and implications for the meat sector. Journal of Agricultural and

Environmental Ethics, 26(3), 629-661. doi:https://doi.org/10.1007/s10806$\underline{012-9426-7}$

De Jonge, J., \& Van Trijp, H. C. M. (2014). Heterogeneity in consumer perceptions of the animal friendliness of broiler production systems. Food Policy, 49(P1), 174-185. doi:10.1016/j.foodpol.2014.07.008

De Passillé, A. M., \& Rushen, J. (2005). Food safety and environmental issues in animal welfare. Revue scientifique et technique-Office international des épizooties, 24(2), 757.

Directive, E. C. Regulation (EU) 2019/6 of the European Parliament and of the Council of 11 December 2018 on veterinary medicinal products and repealing Directive 2001/82/EC, 2019/6 C.F.R. (2019).

Dixon, L. M. (2020). Slow and steady wins the race: The behaviour and welfare of commercial faster growing broiler breeds compared to a commercial slower growing breed. PLoS One, 15(4), e0231006. doi:https://doi.org/10.1371/journal.pone.0231006

Dunkler, D., Plischke, M., Leffondré, K., \& Heinze, G. (2014). Augmented Backward Elimination: A Pragmatic and Purposeful Way to Develop Statistical Models. PLoS One, 9(11), e113677. doi:https://doi.org/10.1371/journal.pone.0113677

Dunlop, M. W., Blackall, P. J., \& Stuetz, R. M. (2016). Odour emissions from poultry litter - A review litter properties, odour formation and odorant emissions from porous materials. Journal of Environmental Management, 177, 306-319. doi:https://doi.org/10.1016/j.jenvman.2016.04.009

Dutch Ministry of Infrastructure and Water Management. Besluit emissiearme huisvesting, W14.15.0152 C.F.R. (2017).

Dutch Ministry of Infrastructure and Water Management. (2018). Tube heaters in poultry houses. The Hague Retrieved from https://www.infomil.nl/onderwerpen/landbouw/emissiearmestalsystemen/stalbeschrijvingen/\#hc0306243-8038-4a12-a383a961f4b226f8.

Dutch Ministry of Infrastructure and Water Management. (2019). Clean air agreement. Rijksoverheid Retrieved from https://www.rijksoverheid.nl/documenten/convenanten/2020/01/13/bijlage1-schone-lucht-akkoord.

Dutch Ministry of Infrastructure and Water Management. (2020). Kengetallen Leefomgeving. Retrieved from https://www.rwseconomie.n1/kengetallen/kengetallen-leefomgeving.

Dutch Ministry of Instrastructure and Water Management. (2020). Rekenmodel Vee-combistof. Retrieved from 


\section{Chapter 6}

https://www.infomil.nl/onderwerpen/landbouw/emissiearmestalsystemen/rekenmodel-vee-combistof/

Dutch National Institute for Public Health and Environment. (2017). Model to calculate emissions from animal housing. Retrieved from https://www.aerius.nl/nl/factsheets/emissieberekening-stallen/17-03-2017.

Dutch Society for the Protection of Animals. (2021). Historische veranderingen die er toe doen, voor dieren. Retrieved from https://beterleven.dierenbescherming.nl/zakelijk/historischeveranderingen-die-er-toe-doen-voor-dieren/

EFSA. (2010). Scientific Opinion on the influence of genetic parameters on the welfare and the resistance to stress of commercial broilers. EFSA Journal, 8(7), 1666. doi:https://doi.org/10.2903/j.efsa.2010.1666

EFSA. (2014). Guidance on Expert Knowledge Elicitation in Food and Feed Safety Risk Assessment. EFSA Journal, 12(6), 278. doi:https://doi.org/10.2903/j.efsa.2014.3734

Ellen, H. H., Jansen, J., Smit, A., \& Vermeij, I. (2014a). Side benefits from sustainable housing systems. Retrieved from https://edepot.wur.n1/302614

Ellen, H. H., Jansen, J., Smit, A., \& Vermeij, I. (2014b). TerraSea voor vleeskuikens-Nevenvoordelen duurzame stalconcepten.

Ellen, H. H., \& Ogink, N. W. M. (2015). Effecten reducerende technieken op emissies bij biologisch gehouden pluimvee: deskstudie (1570-8616). Retrieved from https://edepot.wur.n1/340629

Eurobarometer. (2005). Attitudes of consumers towards the welfare of farmed animals. Special Eurobarometer, 229, 45-46.

Eurobarometer. (2013). Attitudes of Europeans towards air quality. Retrieved from https://ec.europa.eu/commfrontoffice/publicopinion/flash/fl 360 en.pdf

Eurobarometer. (2015). Attitudes of Europeans towards biodiversity. Retrieved from https://op.europa.eu/nl/publication-detail/-/publication/50bflefd720b-11e9-9f05-01aa75ed71a1/language-en/format-PDF

Eurobarometer. (2016). Attitudes of Europeans towards animal welfare. Retrieved from https://ec.europa.eu/commfrontoffice/publicopinion/index.cfm/ResultDoc/ download/DocumentKy/71348

Eurobarometer. (2017). Attitudes of European citizens towards the environment. Retrieved from https://ec.europa.eu/public_opinion/archives/ebs/ebs_416 en.pdf.

Eurobarometer. (2019a). Attitudes of Europeans towards air quality. Retrieved from Brussels: https://europa.eu/eurobarometer/surveys/detail/2239

Eurobarometer. (2019b). Food Safety in the EU. European Commission Retrieved from https://www.efsa.europa.eu/sites/default/files/corporate publications/files/ Eurobarometer2019 Food-safety-in-the-EU Full-report.pdf. 
European Commission. (2020). Farm to Fork Strategy. Retrieved from https://ec.europa.eu/food/sites/food/files/safety/docs/f2f_actionplan 2020 strategy-info_en.pdf

European Council Directive. Directive 98/58/EC of 20 July 1998 concerning the protection of animals kept for farming purposes, 98/58/EC C.F.R. (1998).

European Council Directive. (2000). The Welfare of Chickens Kept for Meat production (broilers). Retrieved from https://ec.europa.eu/food/sites/food/files/safety/docs/scicom_scah_out39 en.pdf

European Council Directive. Directive 2001/81/EC of the European Parliament and of the council of 23 October 2001 on national emission ceilings or certain atmospheric pollutants, (2001).

European Council Directive. Directive 2003/99/EC of the European Parliament and of the Council of 17 November 2003 on the monitoring of zoonoses and zoonotic agents, (2003).

European Council Directive. Directive 2007/43/EC of 28 June 2007 laying down minimum rules for the protection of chickens kept for meat production, 2007/43/EC C.F.R. (2007).

European Council Directive. Directive 2008/50/EC of the European Parliament and of the Council of 21 May 2008 on ambient air quality and cleaner air for Europe, 226/2008 C.F.R. (2008a).

European Council Directive. Directive 2008/120/EC of 18 December 2008 laying down minimum standards for the protection of pigs, (2008b).

European Council Directive. Regulation (EC) No 1069/2009 of the European Parliament and of the Council of 21 October 2009 laying down health rules as regards animal by-products and derived products not intended for human consumption and repealing Regulation (EC), 1069/2009 C.F.R. (2009).

European Council Directive. Directive 2014/104/EU of the European Parliament and of the council of 26 November 2014 on certain rules governing actions for damages under national law for infringements of the competition law provisions of the Member States and of the European Union, 349/1 C.F.R. (2014).

European Council Directive. Directive 2016/2284 of the European Parliament and of the Council of 14 December 2016 on the reduction of national emissions of certain atmospheric pollutants, 2016/2284 C.F.R. (2016).

European Environment Agency. (2019). Ammonia emissions from agriculture continue to pose problems for Europe. Retrieved from https://www.eea.europa.eu/highlights/ammonia-emissions-fromagriculture-continue.

European Environment Agency. (2020a). Exceedance of air quality standards in Europe. Retrieved from https://www.eea.europa.eu/data-andmaps/indicators/exceedance-of-air-quality-limit-2/assessment 


\section{Chapter 6}

European Environment Agency. (2020b). National emissions reported to the Convention on Long-range Transboundary Air Pollution (LRTAP Convention). Retrieved from: https://www.eea.europa.eu/data-andmaps/data/national-emissions-reported-to-the-convention-on-long-rangetransboundary-air-pollution-lrtap-convention-14

European Environment Agency. (2021). Exceedance of air quality standards in Europe. Retrieved from https://www.eea.europa.eu/data-andmaps/indicators/exceedance-of-air-quality-limit-2/assessment

Eurostat. (2020). Poultry by NUTS 2 regions. Retrieved from: https://appsso.eurostat.ec.europa.eu/nui/submitViewTableAction.do

Expertise Centre Infomil. (2017). Stal met buizenverwarming. Retrieved from https://www.infomil.nl/publish/pages/130041/bwl_2017_01_v2.pdf.

Expertise Centre Infomil. (2019a). Emission factors per animal - broilers. Retrieved from https://www.infomil.nl/onderwerpen/landbouw/stalsystemen/emissiefactor en-per/map-staltypen/5-diercategorie/

Expertise Centre Infomil. (2019b). Emission factors per animal - particulate matter. Retrieved from https://www.infomil.nl/onderwerpen/landbouw/stalsystemen/emissiefactor en-per/map-staltypen/7-additionele/

FAPRI. (2019). FAPRI Elasticity Database. Retrieved from: http://www.fapri.iastate.edu/tools/elasticity.aspx

Ferguson, R., \& Hansson, H. (2013). Expand or exit? Strategic decisions in milk production. Livestock Science, 155(2), 415-423. doi:https://doi.org/10.1016/j.livsci.2013.05.019

Gallet, C. A. (2010). Meat meets meta: a quantitative review of the price elasticity of meat. American Journal of Agricultural Economics, 92(1), 258-272. doi:https://doi.org/10.1093/ajae/aap008

Gasson, R. (1973). Goals and values of farmers. Journal of Agricultural Economics, 24(3), 521-542. doi:https://doi.org/10.1111/j.14779552.1973.tb00952.x

Gerber, P. J., Steinfeld, H., Henderson, B., Mottet, A., Opio, C., Dijkman, J., . . . Tempio, G. (2013). Tackling climate change through livestock: a global assessment of emissions and mitigation opportunities: Food and Agriculture Organization of the United Nations (FAO).

Gocsik, É., Brooshooft, S. D., De Jong, I. C., \& Saatkamp, H. W. (2016a). Costefficiency of animal welfare in broiler production systems: A pilot study using the Welfare Quality ${ }^{\circledR}$ assessment protocol. Agricultural Systems, 146, 55-69. doi:https://doi.org/10.1016/j.agsy.2016.04.001

Gocsik, É., Oude Lansink, A. G. J. M., \& Saatkamp, H. W. (2013). Mid-term financial impact of animal welfare improvements in Dutch broiler production. Poultry Science, 92(12), 3314-3329. doi:https://doi.org/10.3382/ps.2013-03221 
Gocsik, É., Van der Lans, I. A., Oude Lansink, A. G. J. M., \& Saatkamp, H. W. (2015). Willingness of Dutch broiler and pig farmers to convert to production systems with improved welfare. Animal Welfare, 24(2), 211222. doi:https://doi.org/10.7120/09627286.24.2.211

Gocsik, É., Van der Lans, I. A., Oude Lansink, A. G. J. M., \& Saatkamp, H. W. (2016b). Elicitation of preferences of Dutch broiler and pig farmers to support decision making on animal welfare. NJAS - Wageningen Journal of Life Sciences, 76, 75-86. doi:https://doi.org/10.1016/j.njas.2015.11.006

Grantz, D. A., Garner, J. H. B., \& Johnson, D. W. (2003). Ecological effects of particulate matter. Environment international, 29(2), 213-239. doi:https://doi.org/10.1016/S0160-4120(02)00181-2

Groot Koerkamp, P. W. G., Middelkoop, J. H., \& Evers, E. (2000). Ammoniakemissie vleeskuikenstallen toegenomen. Pluimveehouderij, 30, $10-11$.

Hansson, H., \& Sok, J. (2021). Perceived obstacles for business development: Construct development and the impact of farmers' personal values and personality profile in the Swedish agricultural context. Journal of Rural Studies, 81, 17-26. doi:https://doi.org/10.1016/j.jrurstud.2020.12.004

Henson, S., \& Humphrey, J. (2010). Understanding the Complexities of Private Standards in Global Agri-Food Chains as They Impact Developing Countries. The Journal of Development Studies, 46(9), 1628-1646. doi:https://doi.org/10.1080/00220381003706494

Homidan, A. A., Robertson, J. F., \& Petchey, A. M. (2003). Review of the effect of ammonia and dust concentrations on broiler performance. World's Poultry Science Journal, 59(3), 340-349. doi:https://doi.org/10.1079/WPS20030021

Howley, P. (2015). The Happy Farmer: The Effect of Nonpecuniary Benefits on Behavior. American Journal of Agricultural Economics, 97(4), 1072-1086. doi:https://doi.org/10.1093/ajae/aav020

Hudson, D., \& Lusk, J. (2004). Risk and Transactions Cost in Contracting: Results from a Choice-Based Experiment. Journal of Agricultural \& Food Industrial Organization, 2(1). doi:https://doi.org/10.2202/1542-0485.1046

Isik, M. (2004). Incentives for Technology Adoption Under Environmental Policy Uncertainty: Implications for Green Payment Programs. Environmental and Resource Economics, 27(3), 247-263. doi:https://doi.org/10.1023/B:EARE.0000017624.07757.3f

Jensen, J. D., Christensen, T., Denver, S., Ditlevsen, K., Lassen, J., \& Teuber, R. (2019). Heterogeneity in consumers' perceptions and demand for local (organic) food products. Food quality and preference, 73, 255-265. doi:https://doi.org/10.1016/j.foodqual.2018.11.002

Johnson, R., \& Orme, B. (2003). Getting the most from CBC. Sequim: Sawtooth Software Research Paper Series, Sawtooth Software.

Joshi, P. K., Khan, M. T., \& Kishore, A. (2019). Heterogeneity in male and female farmers' preference for a profit-enhancing and labor-saving technology: 


\section{Chapter 6}

The case of Direct-Seeded Rice (DSR) in India. Canadian Journal of Agricultural Economics, 67(3), 303-320. doi:10.1111/cjag.12205

Keele, L. (2007). Social Capital and the Dynamics of Trust in Government. American Journal of Political Science, 51(2), 241-254. doi:https://doi.org/10.1111/j.1540-5907.2007.00248.x

Kjaer, J. B., Su, G., Nielsen, B. L., \& Sørensen, P. (2006). Foot pad dermatitis and hock burn in broiler chickens and degree of inheritance. Poultry Science, 85(8), 1342-1348. doi:https://doi.org/10.1093/ps/85.8.1342

Knowles, T. G., Kestin, S. C., Haslam, S. M., Brown, S. N., Green, L. E., Butterworth, A., . . . Nicol, C. J. (2008). Leg disorders in broiler chickens: prevalence, risk factors and prevention. PLoS One, 3(2), e1545. doi:https://doi.org/10.1371/journal.pone.0001545

Lagerkvist, C. J. (2005). Agricultural policy uncertainty and farm level adjustments - the case of direct payments and incentives for farmland investment. European Review of Agricultural Economics, 32(1), 1-23. doi:https://doi.org/10.1093/erae/jbi005

Lagerkvist, C. J., Hansson, H., Hess, S., \& Hoffman, R. (2011). Provision of Farm Animal Welfare: Integrating Productivity and Non-Use Values. Applied Economic Perspectives and Policy, 33(4), 484-509. doi:https://doi.org/10.1093/aepp/ppr037

Lammel, G., Schneider, F., Brüggemann, E., Gnauk, T., Röhrl, A., \& Wieser, P. (2004). Aerosols Emitted from a Livestock Farm in Southern Germany. Water, Air, and Soil Pollution, 154(1), 313-330. doi:https://doi.org/10.1023/B:WATE.0000022962.65942.4b

Lancaster, K. J. (1966). A New Approach to Consumer Theory. Journal of Political Economy, 74(2), 132-157. doi:https://doi.org/10.1086/259131

Lancsar, E., Louviere, J., \& Flynn, T. (2007). Several methods to investigate relative attribute impact in stated preference experiments. Social Science \& Medicine, 64(8), 1738-1753. doi:https://doi.org/10.1016/j.socscimed.2006.12.007

Lebacq, T., Baret, P. V., \& Stilmant, D. (2013). Sustainability indicators for livestock farming. A review. Agronomy for Sustainable Development, 33(2), 311-327. doi:https://doi.org/10.1007/s13593-012-0121-x

Leinonen, I., \& Kyriazakis, I. (2016). How can we improve the environmental sustainability of poultry production? Proc Nutr Soc, 75(3), 265-273. doi:10.1017/S0029665116000094

Leinonen, I., Williams, A. G., \& Kyriazakis, I. (2014). The effects of welfareenhancing system changes on the environmental impacts of broiler and egg production. Poultry Science, 93(2), 256-266. doi:https://doi.org/10.3382/ps.2013-03252

Leinonen, I., Williams, A. G., Waller, A. H., \& Kyriazakis, I. (2013). Comparing the environmental impacts of alternative protein crops in poultry diets: The consequences of uncertainty. Agricultural Systems, 121, 33-42. doi:10.1016/j.agsy.2013.06.008 
Leinonen, I., Williams, A. G., Wiseman, J., Guy, J., \& Kyriazakis, I. (2012). Predicting the environmental impacts of chicken systems in the United Kingdom through a life cycle assessment: Broiler production systems. Poultry Science, 91(1), 8-25. doi:https://doi.org/10.3382/ps.2011-01634

Li, S., \& Kallas, Z. (2021). Meta-analysis of consumers' willingness to pay for sustainable food products. Appetite, 163, 105239. doi:https://doi.org/10.1016/j.appet.2021.105239

Long, T. B., Blok, V., \& Coninx, I. (2016). Barriers to the adoption and diffusion of technological innovations for climate-smart agriculture in Europe: evidence from the Netherlands, France, Switzerland and Italy. Journal of Cleaner Production, 112, 9-21. doi:https://doi.org/10.1016/j.jclepro.2015.06.044

Lundmark, F., Berg, C., \& Röcklinsberg, H. (2018). Private Animal Welfare Standards - Opportunities and Risks. Animals, 8(1), 4.

Lusk, J. L., \& McCluskey, J. (2018). Understanding the Impacts of Food Consumer Choice and Food Policy Outcomes. Applied Economic Perspectives and Policy, 40(1), 5-21. doi:https://doi.org/10.1093/aepp/ppx054

Lusk, J. L., \& Norwood, F. B. (2011). Animal Welfare Economics. Applied Economic Perspectives and Policy, 33(4), 463-483. doi:https://doi.org/10.1093/aepp/ppr036

Lusk, J. L., Pruitt, J. R., \& Norwood, F. B. (2006). Consumer Demand for a Ban on Antibiotic Drug Use in Pork Production. American Journal of Agricultural Economics, 88(4), 1015-1033. doi:https://doi.org/10.1111/j.14678276.2006.00913.x

Mangham, L. J., Hanson, K., \& McPake, B. (2008). How to do (or not to do) ... Designing a discrete choice experiment for application in a low-income country. Health Policy and Planning, 24(2), 151-158. doi:https://doi.org/10.1093/heapol/czn047

Mazzanti, M. (2003). Discrete choice models and valuation experiments. Journal of Economic Studies, 30(5/6), 584-604. doi:http://dx.doi.org/10.1108/01443580310504453

McFadden, D. (1974). The measurement of urban travel demand. Journal of Public Economics, 3(4), 303-328. doi:https://doi.org/10.1016/0047$\underline{2727(74) 90003-6}$

McFadden, D. (1979). Quantitative methods for analysing travel behaviour of individuals: some recent developments: Routledge.

Meerburg, B., Korevaar, H., Haubenhofer, D., Blom-Zandstra, M., \& Van Keulen, H. (2009). The changing role of agriculture in Dutch society. The Journal of Agricultural Science, 147(5), 511. doi:https://doi.org/10.1017/S0021859609990049

Melse, R. W. (2009). Air treatment techniques for abatement of emissions from intensive livestock production. Retrieved from http://edepot.wur.nl/12452 WorldCat.org database. 


\section{Chapter 6}

Melse, R. W., \& Ogink, N. W. M. (2005). Air scrubbing techniques for ammonia and odor reduction at livestock operations: review of on-farm research in the Netherlands. Transactions of the American Society of Agricultural Engineers, 48(6), 2303-2313.

Melse, R. W., van Wagenberg, A. V., \& Mosquera, J. (2006). Size reduction of ammonia scrubbers for pig and poultry houses: use of conditional bypass vent at high air loading rates. Biosystems Engineering, 95(1), 69-82. doi:https://doi.org/10.1016/j.biosystemseng.2006.05.006

Miele, M., Blokhuis, H. J., Bennett, R., \& Bock, B. (2013). Changes in farming and in stakeholder concern for animal welfare. In Improving farm animal welfare (pp. 19-47): Springer.

Ministry of Agriculture, N. a. F. Q. Regeling Diergeneesmiddelen, (2019).

Muaz, K., Riaz, M., Akthar, S., Park, S., \& Ismail, A. (2018). Antibiotic Residues in Chicken Meat: Global Prevalence, Threats, and Decontamination Strategies: A Review. Journal of Food Protection, 81(4), 619-627. doi:10.4315/0362-028x.Jfp-17-086

Namroud, N. F., Shivazad, M., \& Zaghari, M. (2008). Effects of Fortifying Low Crude Protein Diet with Crystalline Amino Acids on Performance, Blood Ammonia Level, and Excreta Characteristics of Broiler Chicks. Poultry Science, 87(11), 2250-2258. doi:https://doi.org/10.3382/ps.2007-00499

Netherlands Authority for Consumers \& Markets. (2021). Guidelines on sustainability agreements are ready for further coordination. Retrieved from https:/www.acm.nl/en/publications/guidelines-sustainabilityagreements-are-ready-further-european-coordination

Netherlands Enterprise Agency. (2020a). Antibiotic resistance in the livestock industry. Retrieved from https://www.government.nl/topics/antibioticresistance/antibiotic-resistance-in-livestockfarming\#: : text $=$ Less $\% 20$ antibiotic $\% 20$ use $\% 20$ in $\% 20$ the, have $\% 20$ fallen $\%$ 20by $\% 20$ another $\% 2011 \% 25$.

Netherlands Enterprise Agency. (2020b). Investing in innovative techniques in animal husbandry. Retrieved from https://www.rvo.nl/subsidie-enfinancieringswijzer/innovatie-en-verduurzaming-stallen

OECD. (2008). Handbook on constructing composite indicators: methodology and user guide. Retrieved from https://www.oecd.org/sdd/42495745.pdf

Orme, B. (1998). Sample size issues for conjoint analysis studies. Sequim: Sawtooth Software Technical Paper.

Pashaei Kamali, F. P. (2015). Sustainability Performance of Soybean and Beef Chains in Latin America. (Dissertation), Wageningen.

Peña Fernández, A., Demmers, T. G. M., Tong, Q., Youssef, A., Norton, T., Vranken, E., \& Berckmans, D. (2019). Real-time modelling of indoor particulate matter concentration in poultry houses using broiler activity and ventilation rate. Biosystems Engineering, 187, 214-225.

doi:https://doi.org/10.1016/i.biosystemseng.2019.09.004 
Plastina, A., \& Giannakas, K. (2007). Market and welfare effects of GMO introduction in small open economies. AgBioForum, 10(2), 104-123.

R Core team. (2020). R: A language and environment for statistical computing. Vienna, Austria. Retrieved from https://www.R-project.org/

Raedts, P. J. M., Garcia, S. C., Chapman, D. F., Edwards, G. R., Lane, N., \& Rawnsley, R. P. (2017). Is systems research addressing the current and future needs of dairy farms? Animal Production Science, 57(7), 1311-1322. doi:https://doi.org/10.1071/AN16647

Reinders, M., Poppe, K. J., Immink, V., Van den Broek, E., Van Horne, P. L. M., \& Hoste, R. (2013). Waardevolle perspectieven voor vlees. Retrieved from Den Haag: https://edepot.wur.nl/296834

Riber, A. B., Van de Weerd, H. A., De Jong, I. C., \& Steenfeldt, S. (2018). Review of environmental enrichment for broiler chickens. Poultry Science, 97(2), 378-396. doi:https://doi.org/10.3382/ps/pex344

Rocchi, L., Paolotti, L., Rosati, A., Boggia, A., \& Castellini, C. (2019). Assessing the sustainability of different poultry production systems: A multicriteria approach. Journal of Cleaner Production, 211, 103-114. doi:https://doiorg.ezproxy.library.wur.n1/10.1016/j.jclepro.2018.11.013

Rodenburg, T. B., \& Koene, P. (2007). The impact of group size on damaging behaviours, aggression, fear and stress in farm animals. Applied Animal Behaviour Science, 103(3-4), 205-214. doi:https://doi.org/10.1016/j.applanim.2006.05.024

Rougoor, C., \& Van der Schans, F. (2019). Vergelijking milieueffecten vleeskuikenconcepten. Retrieved from https://www.pluimveeloket.be/sites/default/files/inline-files/201910\%20CLMrapport-Vergelijking milieueffecten_vleeskuikenconcepten.pdf

Saatkamp, H. W., Vissers, L. S. M., Van Horne, P. L. M., \& De Jong, I. C. (2019). Transition from conventional broiler meat to meat from production concepts with higher animal welfare: experiences from The Netherlands. Animals, 9(8). doi:https://doi.org/10.3390/ani9080483

Saitone, T. L., Sexton, R. J., \& Sumner, D. A. (2015). What Happens When Food Marketers Require Restrictive Farming Practices? American Journal of Agricultural Economics, 97(4), 1021-1043. doi:https://doi.org/10.1093/ajae/aav021

Sawtooth Software. (2018). Which Conjoint Method Grid. Retrieved from https://sawtoothsoftware.com/resources/knowledge-base/salesquestions/which-conjoint-method-grid

Sawtooth Software. (2021a). Conditional pricing. Retrieved from https://sawtoothsoftware.com/help/lighthousestudio/manual/hid web cbc cp.html

Sawtooth Software. (2021b). Sawtooth software version 4.4.6. Provo: Sawtooth Software. Retrieved from https://sawtoothsoftware.com/ 


\section{Chapter 6}

Seedorf, J. (2004). An emission inventory of livestock-related bioaerosols for Lower Saxony, Germany. Atmospheric Environment, 38(38), 6565-6581. doi:https://doi.org/10.1016/j.atmosenv.2004.08.023

Segerson, K. (2013). When Is Reliance on Voluntary Approaches in Agriculture Likely to Be Effective? Applied Economic Perspectives and Policy, 35(4), 565-592. doi:https://doi.org/10.1093/aepp/ppt030

Sørensen, P., Su, G., \& Kestin, S. C. (2000). Effects of Age and Stocking Density on Leg Weakness in Broiler Chickens. Poultry Science 79(6), 864-870. doi:https://doi.org/10.1093/ps/79.6.864

Stadig, L. (2019). Vleeskuikenconcepten in Nederland. Retrieved from https:/www.pluimveeloket.be/sites/default/files/inline-files/2019-1010\%20Welzijnsvergelijking\%20vleeskuikenconcepten.pdf

Stadig, L. M., Rodenburg, T. B., Ampe, B., Reubens, B., \& Tuyttens, F. A. M. (2017). Effect of free-range access, shelter type and weather conditions on free-range use and welfare of slow-growing broiler chickens. Applied Animal Behaviour Science, 192, 15-23. doi:https://doi.org/10.1016/j.applanim.2016.11.008

StataCorp. (2019). Stata Statistical Software: Release 16. College Station, TX: StataCorp LP.

Steinfeld, H. (2006). Livestock's long shadow : environmental issues and options. Rome :: Food and Agriculture Organization of the United Nations.

Swinnen, J., Deconinck, K., Vandemoortele, T., \& Vandeplas, A. (2015). Quality standards, value chains, and international development: economic and political theory. New York: Cambridge University Press.

Tallentire, C. W., Leinonen, I., \& Kyriazakis, I. (2018). Artificial selection for improved energy efficiency is reaching its limits in broiler chickens. Scientific Reports, 8(1), 1168. doi:10.1038/s41598-018-19231-2

TNO. (2019). Factsheet emissies en depositie van stikstof in Nederland. Retrieved from The Hague:

https://publications.tno.nl/publication/34634850/8Pywsn/TNO-2019emissies.pdf

Tullo, E., Fontana, I., Peña Fernández, A., Vranken, E., Norton, T., Berckmans, D., \& Guarino, M. (2017). Association between environmental predisposing risk factors and leg disorders in broiler chickens. Journal of Animal Science, 95(4), 1512-1520. doi:https://doi.org/10.2527/jas.2016.1257

United States Environmental Protection Agency. (2020). Particulate Matter (PM) Basics. Retrieved from https://www.epa.gov/pm-pollution/particulatematter-pm-basics

Van de Gucht, T., Saeys, W., Van nuffel, A., Pluym, L., Piccart, K., Lauwers, L., . . . Van weyenberg, S. (2017). Farmers' preferences for automatic lamenessdetection systems in dairy cattle. Journal of dairy science, 100(7), 57465757. doi:10.3168/jds.2016-12285

Van der Meulen, H., Van der Meer, R., \& Van Asseldonk, M. (2020). Financiering transitie naar duurzame landbouw : inzicht in het huidige 
financieringslandschap en ontwikkelingen. In Rapport / Wageningen Economic Research ; 2020-097. Retrieved from https://doi.org/10.18174/532092

Van Galen, M., Baltussen, W., Gardebroek, K., Herceglić, N., Hoste, R., Ihle, R., . . . Kornelis, M. (2020). Agro-Nutri Monitor 2020: Monitor prijsvorming voedingsmiddelen en analyse belemmeringen voor verduurzaming: Wageningen Economic Research.

Van Geijlswijk, I. M., Heederik, D., Mouton, J. W., Wagenaar, J. A., Jacobs, J. H., \& Sanders, P. (2019). Usage of Antibiotics in Agricultural Livestock in the Netherlands in 2018. Retrieved from https://cdn.ipulse.nl/autoriteitdiergeneesmiddelen/userfiles/Publications/2018-defrapport1.pdf

Van Harn, J., Dijkslag, M. A., \& van Krimpen, M. M. (2019). Effect of low protein diets supplemented with free amino acids on growth performance, slaughter yield, litter quality, and footpad lesions of male broilers. Poultry Science, 98(10), 4868-4877. doi:https://doi.org/10.3382/ps/pez229

Van Harn, J. V., Aarnink, A. J. A., Mosquera, J., Van Riel, J. W., \& Ogink, N. W. M. (2012). Effect of bedding material on dust and ammonia emission from broiler houses. Transactions of the ASABE, 55(1), 219-226.

Van Harn, J. V., Ellen, H. H., Van Riel, J. W., \& Huis in 't Veld, J. W. H. (2015). Effect of low emission techniques on mortality rate and footpad dermatitis score of broilers. In. Retrieved from http://edepot.wur.nl/331377

Van Horne, P. L. M. (2017). Competitiveness of the EU poultry meat sector, base year 2015; International comparison of production costs. Retrieved from http://edepot.wur.nl/404949

Van Horne, P. L. M. (2020a). Economics of broiler production systems in the Netherlands: economic aspects within the Greenwell sustainability assessment model. Retrieved from Wageningen: https://edepot.wur.nl/518522

Van Horne, P. L. M. (2020b). Pluimveevleessector in Nederland - Feiten en cijfers rondom pluimveevlees. Retrieved from https://edepot.wur.nl/530584

Vanhonacker, F., \& Verbeke, W. (2014). Public and Consumer Policies for Higher Welfare Food Products: Challenges and Opportunities. Journal of Agricultural and Environmental Ethics, 27(1), 153-171. doi:10.1007/s10806-013-9479-2

Verspecht, A., Vanhonacker, F., Verbeke, W., Zoons, J., \& Van Huylenbroeck, G. (2011). Economic impact of decreasing stocking densities in broiler production in Belgium. Poultry Science, 90(8), 1844-1851. doi:https://doi.org/10.3382/ps.2010-01277

Vissers, L. S. M., De Jong, I. C., van Horne, P. L. M., \& Saatkamp, H. W. (2019). Global prospects of the cost-efficiency of broiler welfare in middlesegment production systems. Animals (Basel), 9(7). doi:https://doi.org/10.3390/ani9070473 


\section{Chapter 6}

Vissers, L. S. M., Jongeneel, R. A., Saatkamp, H. W., \& Oude Lansink, A. G. J. M. (2021a). A multiple-standards framework to address externalities resulting from meat production. Applied Economic Perspectives and Policy, 1-14. doi:https://doi.org/10.1002/aepp.13152

Vissers, L. S. M., Oude Lansink, A. G. J. M., \& Saatkamp, H. W. (2021b). Exploring the performance of system changes in Dutch broiler production to balance animal welfare, ammonia emissions and particulate matter emissions with farm profitability. Agricultural Systems, 193. doi:https://doi.org/10.1016/j.agsy.2021.103217

Vissers, L. S. M., Saatkamp, H. W., \& Oude Lansink, A. G. J. M. (2021c). Analysis of synergies and trade-offs between animal welfare, ammonia emission, particulate matter emission and antibiotic use in Dutch broiler production systems. Agricultural Systems, 189, 103070. doi:https://doi.org/10.1016/j.agsy.2021.103070

Wageningen Economic Research. (2021). Dutch FADN, agriculture. Retrieved from https://www.agrimatie.nl/themaResultaat.aspx?subpubID=2232\&sectorID $=2258 \&$ themaID $=2265 \&$ indicatorID $=2009$

Wagner, S., Angenendt, E., Beletskaya, O., \& Zeddies, J. (2015). Costs and benefits of ammonia and particulate matter abatement in German agriculture including interactions with greenhouse gas emissions. Agricultural Systems, 141, 58-68. doi:https://doi.org/10.1016/j.agsy.2015.09.003

Waldenstedt, L. (2006). Nutritional factors of importance for optimal leg health in broilers: A review. Animal Feed Science and Technology, 126(3), 291-307. doi:https://doi.org/10.1016/j.anifeedsci.2005.08.008

Welfare Quality Protocol ${ }^{\circledR}$. (2009). Welfare Quality ${ }^{\circledR}$ assessment protocol for poultry (broilers, laying hens). Retrieved from https://edepot.wur.nl/233471

Wilson, G. A., \& Hart, K. (2000). Financial imperative or conservation concern? EU farmers' motivations for participation in voluntary agri-environmental schemes. Environment and planning A, 32(12), 2161-2185.

Winkel, A., Mosquera, J., Groot Koerkamp, P. W. G., Ogink, N. W. M., \& Aarnink, A. J. A. (2015). Emissions of particulate matter from animal houses in the Netherlands. Atmospheric Environment, 111, 202-212. doi:https://doi.org/10.1016/j.atmosenv.2015.03.047

Winter, M., Fry, C., \& Carruthers, S. P. (1998). European agricultural policy and farm animal welfare. Food Policy, 23(3), 305-323. doi:https://doi.org/10.1016/S0306-9192(98)00036-0

Wood, D. J., \& Van Heyst, B. J. (2016). A review of ammonia and particulate matter control strategies for poultry housing. Transactions of the ASABE, 59(1), 329-344. doi:https://doi.org/10.13031/trans.59.10836

Zemo, K. H., \& Termansen, M. (2018). Farmers' willingness to participate in collective biogas investment: A discrete choice experiment study. 
Resource and Energy Economics, 52, 87-101.

doi:https://doi.org/10.1016/j.reseneeco.2017.12.001

Zuidhof, M. J., Schneider, B. L., Carney, V. L., Korver, D. R., \& Robinson, F. E. (2014). Growth, efficiency, and yield of commercial broilers from 1957, 1978, and 2005. Poultry Science, 93(12), 2970-2982.

doi:https://doi.org/10.3382/ps.2014-04291 


\section{Summary}

\section{Samenvatting}

Acknowledgements

About the author

\section{Training and supervision plan}




\section{Summary}

\section{Summary}

The intensification of livestock production in North-West Europe resulted in growing societal concerns and heated debates about the negative impact of livestock production on animal welfare, the environment, biodiversity and human health. To counteract these concerns, the European Union and national governments passed legislation to improve animal welfare (AW), food safety and the environment in the early 2000s. Despite this legislation, public concerns persisted. In the Netherlands, stakeholders in broiler supply chains introduced more extensive systems to address the concern related to AW. As these systems focus on only a single issue of concern, i.e. AW, they do not mitigate the concern related to other externalities. In fact, these systems have a higher potential to contribute to acidification and eutrophication (expressed per $\mathrm{kg}$ edible carcass weight produced) compared to intensive conventional systems. The foregoing suggests that switching from conventional to more extensive systems addresses AW concerns but increases environmental concerns.

To address the persistent societal critique, the European Union, national governments and chain actors introduced new goals. These goals can be achieved by developing sustainable broiler production systems. Various system changes can be applied to improve the sustainability of broiler production systems, such as sustainable farming practices or an emission abatement technique. A system change may yield synergies or trade-offs between externalities. A synergy is defined as the mitigation of multiple negative externalities, whereas a trade-off is defined as the mitigation of one negative externality and the elevation of another. The existing literature does not provide insight into the contribution of individual system changes on multiple externalities, including the synergies and trade-offs between these externalities. As the Dutch broiler market is characterized by small profit margins, minor changes in the production system can have a large impact on production costs and hence on farm income. Exploiting synergies and minimizing trade-offs can therefore contribute considerably to the development of broiler production systems that address multiple externalities. The overall objective of this dissertation was to explore broiler production systems that address multiple externalities and are aligned with farmers' preferences.

Chapter 2 developed a framework for assessing the implementation of standards in a context of multiple negative externalities resulting from meat production. In the framework, it was assumed that the following three conditions have to be satisfied 
for a more stringent to be economically feasible: 1) producers' profits are not decreasing 2) retailers' profits are not decreasing 3) the increase in willingness-topay equals or exceeds the increase in consumer price needed to cover all additional costs of the more stringent standard. The framework conceptualized the effect of synergies and trade-offs between externalities on production costs and willingnessto-pay. The framework demonstrated that synergies enhance the economic feasibility of more stringent standards, whereas trade-offs hamper the economic feasibility of these standards. The framework was applied to the introduction of the new Dutch retail standard (NRDS) in the Dutch broiler market, a standard on AW initiated by the private sector with national coverage. The results showed that this standard did not lower producer, retailer, and consumer welfare; rather, social welfare increased by approximately 300 million euros. The standard enhanced AW, lowered the use of antibiotics and did not result in higher greenhouse gas emissions (on a national level). The findings suggested that the government should consider a different response to these standards as they may be welfare enhancing and may contribute to multiple policy goals.

Chapter 3 developed an approach to analyze synergies and trade-offs between externalities in broiler production systems. The approach was applied to the Dutch conventional, NDRS and Extensive Indoor+ system. Four externalities were considered, i.e. $\mathrm{AW}$, ammonia $\left(\mathrm{NH}_{3}\right)$ emissions, particulate matter $\left(\mathrm{PM}_{10}\right)$ emissions and antibiotic use. A stochastic simulation model was developed to estimate the externalities and the farm income generated from these systems. The results showed that the shift from a fast-growing breed towards a slower-growing breed caused synergy by improving AW and lowering antibiotic use. The reduction in protein content of the feed, and possibly the reduction in stocking density, caused synergy by enhancing $\mathrm{AW}$ and lowering $\mathrm{NH}_{3}$ emissions. Most system changes that enhanced AW caused a trade-off with $\mathrm{PM}_{10}$ emissions. The system changes implemented in the NDRS and extensive indoor+ system resulted in higher $\mathrm{NH}_{3}$ and $\mathrm{PM}_{10}$ emissions per animal place per year relative to the conventional system. However, experts estimated that these emissions were partially (NDRS) or fully (Extensive Indoor+) offset at farm level via a lower stocking density. The study concluded that future broiler production systems can utilize the synergy between $\mathrm{AW}$, antibiotic use, and $\mathrm{NH}_{3}$ emissions and can minimize the trade-off between $\mathrm{AW}$ and $\mathrm{PM}_{10}$ emissions.

Chapter 4 explored the performance of combinations of systems changes in terms their potential for improving $\mathrm{AW}$ and mitigating emissions of $\mathrm{NH}_{3}$ and $\mathrm{PM}_{10}$, and 


\section{Summary}

their impact on farm income. Furthermore, this chapter explored the extent to which these combinations were robust to changes in the societal attitude towards these externalities. The NDRS was used as a baseline for evaluating the system changes. Farm income was indicated by the net return to labor and management (total revenues minus total costs excluding labor costs). The model developed in Chapter 3 was used to estimate the effect of each combination of system changes on the net return to labor and management and externalities. The performance of each combination was evaluated by estimating a benefit-of-the-doubt composite indicator. The results showed that a considerable improvement in $\mathrm{AW}$, and considerable reductions in $\mathrm{NH}_{3}$ emissions (66-73\%) and $\mathrm{PM}_{10}$ emissions (41-61\%) can be achieved at a limited increase in the producer price (5-19\%). The study concluded that the best performing and robust combinations included two or more of the following AW-related system changes: a lower stocking density $\left(30 \mathrm{~kg} / \mathrm{m}^{2}\right)$, environmental enrichment and/or daylight. Furthermore, these combinations included tube heaters to reduce $\mathrm{NH}_{3}$ emissions, and an ionization technique to reduce $\mathrm{PM}_{10}$ emissions.

Chapter 5 measured broiler farmers' preferences for investments in different $\mathrm{PM}_{10}$ abatement techniques and explored the relations with socio-economic demographics and perceived obstacles for business development. A discrete choice experiment was conducted for this purpose. A questionnaire was developed for the experiment and was distributed among 500 broilers farmers, of which 63 broiler farmers completed the questionnaire. The results showed that farmers had a general preference for techniques with a medium to high $\mathrm{PM}_{10}$ reduction efficiency (31$52 \%)$, rather than the technique with a very high $\mathrm{PM}_{10}$ reduction efficiency $(80 \%)$. The likelihood that farmers invest in $\mathrm{PM}_{10}$ abatement techniques increased when a subsidy ( $40 \%$ or $60 \%$ ) or exemption from future legislation (10 or 15 years) was provided. The farmers attached a higher relative importance to an exemption from future legislation than a subsidy. Results showed a high heterogeneity in farmers' preferences for investments in these techniques, which could particularly be explained by social factors (e.g. availability of successor) and perceived obstacles for business development (e.g. rules and regulation). It was concluded that farmers are reluctant to invest in $\mathrm{PM}_{10}$ abatement techniques, i.e. prefer the status quo. The findings imply that policy-related certainty should be provided in addition to a financial compensation to incentivize farmers to reduce $\mathrm{PM}_{10}$ emissions.

Chapter 6 synthesized the results and reflected on the data, materials and methods. This chapter also discussed the business and policy implications and outlined 
directions for future research. Overall, this dissertation underlined that the development of new broiler production systems should focus on an integrated approach that takes the optimization of synergies trade-offs between externalities into account. From this dissertation, the following conclusions are drawn:

- Synergies enhance the economic feasibility of standards that aim to address externalities resulting from meat production, whereas trade-offs hamper the economic feasibility of these standards (Chapter 2).

- Market failure related to production externalities can be successfully addressed by private standards provided that the standard does not lower producer, retailer and consumer welfare (Chapter 2).

- Not only a financial compensation, but also certainty about future emission legislation is an important determinant for the adoption of more stringent environmental standards by Dutch broiler farmers (Chapter 2 and 5).

- In more extensive Dutch broiler production systems, elevated $\mathrm{NH}_{3}$ and $\mathrm{PM}_{10}$ emissions per animal were partly (NDRS) or fully offset (Extensive Indoor+) at farm level due to a reduction in the stocking density (Chapter 3).

- The best performing system changes that enhanced AW caused a trade-off with $\mathrm{PM}_{10}$ emissions, but did not necessarily cause trade-off with $\mathrm{NH}_{3}$ emissions (Chapter 3 and 4).

- Considerable improvements in AW and considerable reductions in $\mathrm{NH}_{3}$ emissions (66-73\%) and $\mathrm{PM}_{10}$ emissions (41-61\%) can be achieved in the NDRS system at a limited increase in the producer price (5-19\%) (Chapter 4).

- Combinations of system changes that included AW-enhancing management practices, a $\mathrm{NH}_{3}$ abatement technique and a $\mathrm{PM}_{10}$ abatement technique performed best and were robust to potential changes in society's expectations towards externalities (Chapter 4).

- $\mathrm{PM}_{10}$ abatement techniques have the potential to considerably reduce $\mathrm{PM}_{10}$ emissions from broiler houses (up to $80 \%$ ), but broiler farmers are in general reluctant to invest in these techniques (Chapter 4 and 5).

- Farmers have a general preference for techniques with a medium to high $\mathrm{PM}_{10}$ reduction efficiency (31-52\%), rather than techniques with a very high $\mathrm{PM}_{10}$ reduction efficiency ( $80 \%)$ (Chapter 5$)$.

- Farmers that perceived their financial resources as constraining were less willing to invest in $\mathrm{PM}_{10}$ abatement techniques, whereas farmers that perceived the location of the farm as constraining were more willing to invest in $\mathrm{PM}_{10}$ abatement techniques (Chapter 5). 


\section{Samenvatting}

\section{Samenvatting}

De intensivering van de veehouderij in Noordwest-Europa leidde tot toenemende zorgen en verhitte debatten over de negatieve effecten hiervan op dierenwelzijn, het milieu, biodiversiteit en menselijke gezondheid. Als reactie op deze zorgen hebben de Europese Unie en nationale overheden wettelijke minimumeisen opgesteld op het gebied van dierenwelzijn, voedselveiligheid en milieu. Ondanks deze eisen hield de maatschappelijke kritiek op de intensieve veehouderij aan. Om de kritiek op dierenwelzijn te verminderen zijn in Nederland extensievere systemen ingevoerd door spelers in de pluimveevleesketen. Aangezien deze systemen alleen focussen op de maatschappelijke kritiek gerelateerd aan dierenwelzijn, lossen deze systemen niet andere kritiekpunten op, bijvoorbeeld met betrekking tot biodiversiteit en menselijke gezondheid. Extensievere vleeskuikenproductiesystemen leveren in feite een grotere potentiële bijdrage aan verzuring en eutrofiëring vergeleken met intensieve systemen (uitgedrukt per 1,000 kg eetbaar karkasgewicht). Deze bevinding suggereert dat de omschakeling van intensieve naar extensievere vleeskuikenproductiesystemen de kritiek op dierenwelzijn verminderen, maar de milieukritiek doen toenemen.

Om de maatschappelijke bezorgdheden weg te nemen hebben de Europese Unie, nationale overheden en spelers in de pluimveevleesketen nieuwe doelen opgesteld. Het ontwikkelen van duurzame vleeskuikenproductiesystemen is een manier om deze doelen te bereiken. Verschillende systeemveranderingen kunnen worden toegepast om deze systemen te verduurzamen. Deze systeemveranderingen kunnen leiden tot een synergie of uitruil tussen externaliteiten. Een externaliteit is gedefinieerd als een indirect effect (bijv. dierenwelzijn) van de activiteit van een individu (bijv. produceren van vleeskuikens) die het welzijn van een ander individu beïnvloedt. Een synergie is gedefinieerd als een verlaging van meerdere negatieve externaliteiten, en een uitruil als de verlaging één negatieve externaliteit en de verhoging van een andere externaliteit. Momenteel ontbreekt kennis over de synergiën en uitruil tussen externaliteiten in vleeskuikenproductie. Deze kennis is essentieel omdat Nederlandse vleeskuikenhouders in een markt opereren die gekenmerkt wordt door (zeer) kleine winstmarges. Een kleine systeemverandering kan daarom grote invloed hebben op de productiekosten en dus het inkomen van de vleeskuikenhouder. Het benutten van synergiën en het minimaliseren van een uitruil tussen externaliteiten kan daarom een grote bijdrage leveren aan de ontwikkeling van nieuwe vleeskuikenproductiesystemen die meerdere externaliteiten verlagen. De globale doelstelling van dit proefschrift was daarom 
om vleeskuikenproductiesystemen te verkennen die meerdere externaliteiten verlagen en overeenkomen met de voorkeuren van vleeskuikenhouders.

In hoofdstuk 2 is een conceptueel raamwerk ontwikkeld die gebruikt kan worden om de economische haalbaarheid van standaarden te beoordelen die externaliteiten van vleesproductie verlagen. In het raamwerk is verondersteld dat aan drie voorwaarden voldaan moet worden voordat een strengere standaard economisch haalbaar is: 1) winst van producenten neemt niet af 2) winst van retailers neemt niet af 3) toename van de betalingsbereidheid van consumenten is groter dan of gelijk aan de toename in de consumentenprijs die benodigd is om de extra kosten van de standaard te compenseren. Het raamwerk demonstreerde het effect van een synergie en een uitruil tussen externaliteiten op de productiekosten en de betalingsbereidheid van consumenten voor duurzamere vleesproducten. Het raamwerk liet zien dat een synergie de economische haalbaarheid van een strengere standaard verhoogt, terwijl een uitruil tussen externaliteiten de economische haalbaarheid verlaagt. Het raamwerk was toegepast op de casus 'Nederlandse retail standaard'. De Nederlandse retail standaard is een strengere dierenwelzijnsstandaard ingevoerd in de vleeskuikenmarkt. De resultaten lieten zien dat deze standaard de economische welvaart van consumenten, supermarkten en consumenten verhoogde. Bovendien leidde de standaard tot een hoger niveau van dierenwelzijn, een afname van het antibioticagebruik in de vleeskuikenhouderij en geen toename van de broeikasgasemissies (op nationaal niveau). De bevindingen suggereren dat de overheid een andere houding zou moeten aannemen tegenover deze standaarden, aangezien ze welvaart verhogend kunnen zijn en kunnen bijdragen aan beleidsdoelen op het gebied van duurzaamheid.

In hoofdstuk 3 is een methode ontwikkeld om de synergie en uitruil tussen externaliteiten in vleeskuikenproductiesystemen te analyseren. De methode was toegepast op de volgende drie systemen: regulier systeem, Nederlandse retail standaard systeem, en het 1-ster Beter Leven systeem. Vier externaliteiten zijn meegenomen in het onderzoek, namelijk dierenwelzijn, ammoniakemissie $\left(\mathrm{NH}_{3}\right.$ emissie), fijnstofemissie ( $\mathrm{PM}_{10}$ emissie) en antibioticagebruik. Een stochastisch simulatiemodel was ontwikkeld om de externaliteiten en het inkomen te berekenen die worden gegenereerd in deze systemen. De resultaten gaven aan dat het vervangen van een snelgroeiend ras door een trager groeiend ras leidde tot synergie door een toename van dierenwelzijn en een afname van antibioticagebruik. Een lager eiwitgehalte in het voer, en mogelijk een lagere bezettingsdichtheid, leverden synergie op door een toename van dierenwelzijn en een afname van $\mathrm{NH}_{3}$ emissies. 


\section{Samenvatting}

De meeste systeemveranderingen die dierenwelzijn verhoogden, veroorzaakten een uitruil met $\mathrm{PM}_{10}$ emissies. De systeemveranderingen die zijn toegepast in het de Nederlandse retail standaard systeem en het 1-ster Beter Leven systeem leidden tot hogere $\mathrm{NH}_{3}$ en $\mathrm{PM}_{10}$ emissies per vleeskuiken. Experts schatten in dat deze emissies gedeeltelijk (Nederlandse retail standaard) of volledig (1-ster Beter Leven) worden ondervangen op stalniveau omdat er minder vleeskuikens worden gehouden in deze systemen. Uit het onderzoek werd geconcludeerd dat toekomstige vleeskuikenproductiesystemen de synergie tussen dierenwelzijn, antibioticagebruik en $\mathrm{NH}_{3}$ emissies kunnen benutten, en de uitruil tussen dierenwelzijn en $\mathrm{PM}_{10}$ emissies kunnen minimaliseren.

Hoofdstuk 4 verkende de prestaties van combinaties van systemveranderingen in termen van hun potentie om dierenwelzijn te verhogen, $\mathrm{NH}_{3}$ en $\mathrm{PM}_{10}$ emissies te verminderen, en de impact op het inkomen van de vleeskuikenhouder. Bovendien onderzocht dit hoofdstuk in welke mate deze combinaties robuust zijn met betrekking tot veranderingen in de houding van de maatschappij tegenover deze externaliteiten. De Nederlandse retail standaard systeem werd als uitgangspunt genomen voor het evalueren van de systeemveranderingen. Het inkomen van de vleeskuikenhouder was aangegeven door het netto resultaat op arbeid en management (omzet minus totale kosten exclusief arbeidskosten). Het model dat is ontwikkeld in hoofdstuk 3 was gebruikt om het effect van iedere combinatie op de externaliteiten en het netto resultaat op arbeid en management te berekenen. De prestaties van iedere combinatie van systeemveranderingen werd geëvalueerd door de benefit-of-the-doubt indicator. De resultaten lieten zien dat een toename van dierenwelzijn, en een aanzienlijke verlaging van de $\mathrm{NH}_{3}$ emissies (66-73\%) en $\mathrm{PM}_{10}$ emissies (41-62\%) behaald kunnen worden tegen een beperkte stijging van de producentenprijs (5-19\%). De studie concludeerde dat de best presterende en robuuste combinaties de volgende systeemveranderingen bevatten: een lagere bezettingsdichtheid $\left(30 \mathrm{~kg} / \mathrm{m}^{2}\right)$, omgevingsverrijking en/of daglicht. Bovendien bevatten deze combinaties buizenverwarming om $\mathrm{NH}_{3}$ emissies te verlagen en een ionisatietechniek om $\mathrm{PM}_{10}$ emissies te verlagen.

Hoofdstuk 5 analyseerde de voorkeuren van vleeskuikenhouders voor investeringen in verschillende $\mathrm{PM}_{10}$ reducerende technieken. Een vragenlijst was ontwikkeld voor het keuze-experiment en verstuurd naar 500 vleeskuikenhouders, waarvan 63 vleeskuikenhouders de vragenlijst compleet hebben ingevuld. De resultaten gaven aan dat vleeskuikenhouders een voorkeur hebben voor technieken met een gemiddeld tot hoge $\mathrm{PM}_{10}$ emissiereductie (31-52\%), vergeleken met een 
techniek met een zeer hoge $\mathrm{PM}_{10}$ emissiereductie (80\%). De kans dat boeren investeren in deze technieken nam toe wanneer een subsidie ( $40 \%$ of $60 \%)$ of een vrijstelling van toekomstige, strengere $\mathrm{PM}_{10}$ emissie-eisen (10 of 15 jaar) werd verleend. De vleeskuikenhouders hechtten meer belang aan een vrijstelling van toekomstige $\mathrm{PM}_{10}$ emissies eisen dan aan een subsidie. De resultaten gaven aan dat er grote verschillen waren in de voorkeuren van vleeskuikenhouders voor investeringen in deze technieken. Deze verschillen konden met name verklaard worden door sociale factoren (bijv. beschikbaarheid van bedrijfsopvolger) en obstakels die vleeskuikenhouders als een belemmering (bijv. wet- en regelgeving) voor bedrijfsontwikkeling beschouwen. Uit het onderzoek werd geconcludeerd dat vleeskuikenhouders terughoudend zijn om te investeren in $\mathrm{PM}_{10}$ reducerende technieken en een voorkeur hebben voor de status quo. De bevindingen impliceren dat zowel een financiële compensatie als beleidszekerheid moet worden verstrekt om vleeskuikenhouders te stimuleren $\mathrm{PM}_{10}$ emissies te verminderen.

Hoofdstuk 6 synthetiseerde de resultaten en reflecteerde op de data, theorieën en methoden. Het hoofdstuk behandelde ook de bedrijfs- en beleidsimplicaties van het onderzoek en besprak mogelijke richtingen voor toekomstig onderzoek. De algehele conclusie van het onderzoek is dat bij het ontwikkelen van nieuwe vleeskuikenproductiesystemen het integrale karakter centraal moet worden gesteld, waarbij optimalisering van synergiën en uitruil tussen externaliteiten expliciet moet worden meegenomen. Op basis van dit proefschrift zijn de volgende conclusies getrokken:

- Synergie verhoogt de economische haalbaarheid van standaarden die externaliteiten van vleesproductie verminderen, terwijl een uitruil de economische haalbaarheid van deze standaarden verlaagt (Hoofdstuk 2).

- Marktfalen veroorzaakt door productie-externaliteiten kan worden opgelost door een strengere standaard, op voorwaarde dat de standard de welvaart van producenten, retailers en consumenten niet verlaagt (Hoofdstuk 2).

- Niet alleen een financiële compensatie maar ook zekerheid over toekomstige emissiewetgeving is belangrijke factor voor het overnemen van strengere milieustandaarden door Nederlandse vleeskuikenhouders (Hoofdstuk 2 en 5). 


\section{Samenvatting}

- In extensievere Nederlandse vleeskuikenproductiesystemen was de toename in $\mathrm{NH}_{3}$ en $\mathrm{PM}_{10}$ emissies per vleeskuiken gedeeltelijk (Nederlandse retail standaard systeem) of volledig (1-ster Beter Leven systeem) ondervangen op stalniveau door een lagere bezettingsdichtheid (Hoofdstuk 3).

- De best presterende systeemveranderingen die dierenwelzijn verhogen, veroorzaken een uitruil met $\mathrm{PM}_{10}$ emissies maar veroorzaken niet per se een uitruil met $\mathrm{NH}_{3}$ emissies (Hoofdstuk 3 en 4).

- Aanzienlijke verbeteringen in dierenwelzijn, en aanzienlijke verlagingen in $\mathrm{NH}_{3}$ (66-73\%) en $\mathrm{PM}_{10}$ emissies (41-61\%) kunnen worden bereikt in het Nederlandse retail standaard systeem tegen een beperkte stijging van de producentenprijs (5-19\%) (Hoofdstuk 4).

- Combinaties van systeemveranderingen die managementpraktijken, een $\mathrm{NH}_{3}$ emissie reducerende techniek en een $\mathrm{PM}_{10}$ emissie reducerende technieken bevatten, presteerden het best en waren robuust tegen veranderingen in de maatschappelijke houding tegenover deze externaliteiten (Hoofdstuk 4).

- $\mathrm{PM}_{10}$ reducerende technieken hebben de potentie om $\mathrm{PM}_{10}$ emissies uit vleeskuikenstallen aanzienlijk te verlagen (tot $80 \%$ ), maar vleeskuikenhouders zijn terughoudend om te investeren in deze technieken (Hoofdstuk 4 en 5).

- Vleeskuikenhouders hebben een algemene voorkeur voor technieken met een gemiddeld tot hoge $\mathrm{PM}_{10}$ emissiereductie (31-52\%), in vergelijking met technieken met een zeer hoge $\mathrm{PM}_{10}$ emissiereductie (80\%) (Hoofdstuk 5).

- Vleeskuikenhouders die hun financiële middelen als beperkend beschouwden waren minder bereid om te investeren in $\mathrm{PM}_{10}$ reducerende technieken, terwijl vleeskuikenhouders die de locatie van hun bedrijf als beperkend beschouwden meer bereid waren om te investeren in deze technieken (Hoofdstuk 5). 


\section{Acknowledgements}

After four years, the exciting road of my $\mathrm{PhD}$ has come to an end. $\mathrm{My} \mathrm{PhD}$ trajectory wouldn't be a success without the guidance of my supervisors and the support of my friends, family and colleagues. I hereby would like to express my gratitude to them.

First and foremost, I would like to thank my promotor Alfons Oude Lansink and my co-promotor Helmut Saatkamp. Due to their determination and positive attitude, I had the feeling that I would overcome all the challenges in my $\mathrm{PhD}$ research. Alfons, thank you for your guidance and constructive feedback. Your questions challenged me to reflect on my work and sharpened my ideas. Thank you for keeping your office open whenever I wanted to discuss something with you. Helmut, thank you for your supervision and the enthusiasm for my $\mathrm{PhD}$ research. You were always available when I needed your help or suggestions. When I got caught up with irrelevant details, you helped me to understand the bigger picture of my research and to distinguish relevant issues from irrelevant issues. I enjoyed our conversations during meetings, coffee breaks and trips to conferences.

I would like to thank Roel Jongeneel for his contribution to chapter 2. Roel, your knowledge about agricultural policy inspired me. I am grateful to Jaap Sok for his contribution to chapter 5. Jaap, thank you for your dedication to my research. I am grateful for your inputs from the behavioral economic perspective.

I would like to thank my colleagues for the pleasant time I had at the Business Economics Group. I always felt at ease in the group and the positive work environment stimulated me to get the most out of my research. I enjoyed the barbeques, coffee breaks, outings and lunch walks. Anne and Jeannette, thank you for arranging all the financial and secretarial matters regarding my $\mathrm{PhD}$ research. Special thanks to my office mates Melina and John. Melina and John, thank you for all the talks and for exchanging ideas about our research.

I would like to thank my friends Timo, Job, Jurgen, Dirk, Bart, Kris and Vic for all the fun we had all these years. I look back on our trips and activities with great pleasure. Milou, thank you for your support. Whenever I had doubts about my research, you were there to listen to me. I cherish moments we have shared together and I am looking forward to our future. 


\section{Acknowledgements}

Last but not least, I am deeply grateful to my family for their unconditional support and care. Eva, thank you for being such a great sister. Harrie and Leonoor, you were always there to help me when I was struggling with my research. Without your support and care, this success wouldn't have been possible. 


\section{About the author}

Luuk Vissers was born in Tilburg, the Netherlands on April 27, 1993. After graduating from secondary school in 2011, Luuk studied Economics \& Business Economics at Tilburg University. As part his bachelor program, Luuk went on a student exchange program to the University of Pretoria, South Africa. In 2015, Luuk studied Management, Economics and Consumer studies at Wageningen University. During his master program, Luuk specialized in agricultural economics \& rural policy. As part of the master program, he followed an internship at the Raboresearch Food \& Agribusiness department of Rabobank Utrecht.

In 2017, Luuk started his PhD research at the Business Economics Group of Wageningen University. In this research project, Luuk explored broiler production systems that mitigate multiple externalities. The $\mathrm{PhD}$ research was part of an Interreg Europe project called Food Pro-tec-ts. Since October 2021, Luuk is working as a researcher at Wageningen Economic Research. 
Luuk S.M. Vissers

Wageningen School of Social Sciences (WASS)

Completed Training and Supervision Plan

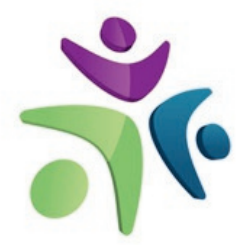

Wageningen School

of Social Sciences

\section{Name of the learning activity Department/Institute}

Year ECTS*

\section{A) Project related competences}

Summer School Sustainable Supply Chains

Theories for Business Decisions, BEC 54806

Advanced Microeconomics, UEC 51806

Research proposal

Summer School Theory and

Practice of Efficiency \&

Productivity Measurement: static

\& dynamic analysis

Business Economics PhD meetings

\section{B) General research related competences}

WASS Introduction Programme WASS

The Essentials of Scientific

WGS

Writing and Presenting

Presentation Skills, ELS 65700

WUR

WUR

Advanced Econometrics, YSS

34306

Scientific writing

'Application of Swinnen's conceptual model on standards to the multi-externality problem in the Dutch broiler market'

WUR

WASS

BEC

WGS
The Association of European

2018

Operational Research Societies

$2017 \quad 6.0$

2018

2018

2018

2019

$2017 \quad 1.0$

$2017 \quad 1.2$

$2019 \quad 1.5$

$2021 \quad 6.0$

$2019 \quad 1.8$

European Forum on System

$2019 \quad 1.0$
Food Networks, Garmisch-

Partenkirchen, Germany 


\section{Training and supervision plan}

'Global prospects of the costefficiency of broiler welfare in middle-segment production systems'

'Development of a multiplestandards framework to address externalities resulting from meat production' $7^{\text {th }}$ European round table on

2019 poultry Economics WPSA, Vechta, Germany

The Wind of Change of 2021 1.0 Sustainability Standards, Gargnano, Italy

\section{C) Career related competences/personal development}

Competence Assessment

Teaching
WASS

$\mathrm{BEC}$
2018

2019-

2021

Total

*One credit according to ECTS is on average equivalent to 28 hours of study load 
The research described in this thesis was financially supported by the Interreg Europe project Food Pro-tec-ts.

Financial support from Wageningen University for printing this thesis is gratefully acknowledged.

Cover design by Myra van Beijsterveldt

Printed by Proefschriftmaken | Proefschriftmaken.nl 
